UNIVERSIDADE DE SÃO PAULO

FACULDADE DE FILOSOFIA, LETRAS E CIÊNCIAS HUMANAS

DEPARTAMENTO DE CIÊNCIA POLÍTICA

PROGRAMA DE PÓS-GRADUAÇÃo EM CIÊNCIA POLÍTICA

Murilo de Oliveira Junqueira

\title{
O Nó Tributário: \\ por que não se aprova uma reforma tributária no Brasil
}

São Paulo

Novembro, 2010 


\section{O Nó Tributário:}

\section{por que não se aprova uma reforma tributária no Brasil}

Murilo de Oliveira Junqueira

Dissertação apresentada ao Programa de Pós-Graduação em Ciência Política, do Departamento de Ciência Política da Faculdade de Filosofia, Letras e Ciências Humanas da Universidade de São Paulo, para a obtenção do título de Mestre em Ciência Política.

Orientadora: Marta T. S. Arretche

São Paulo

Novembro, 2010 


\title{
Resumo:
}

Este trabalho analisa as razões do recorrente fracasso das reformas tributárias no Brasil. Foram estudadas três tentativas de reforma - uma no governo FHC e duas no governo Lula. Apesar de o sistema tributário brasileiro ser muito mal avaliado, todas estas tentativas de reforma falharam. A hipótese central do trabalho é que este fracasso não pode ser explicado pelas estruturas políticas ou federativas, mas pela estratégia dos governos. A ampla insatisfação com os tributos no Brasil induz o governo a propor reformas abrangentes, que alteram muitos aspectos da intrincada estrutura tributária. Estas propostas acabam gerando conflitos multidimensionais, ou seja, o aparecimento de muitas clivagens políticas simultâneas. Também se compara a reforma tributária a outras duas grandes reformas do período: a reforma do judiciário e a reforma administrativa.

\begin{abstract}
This thesis analyzes the reasons for the persistent failure of the tax reforms in Brazil. I studied three attempts at reform - one in Cardoso's and two in Lula's administration. Although the Brazilian tax system is rated very poor, all these attempts have failed. The central hypothesis of this study is that failure can not be explained by political or federal sistem, but by the strategy of governments. Widespread dissatisfaction with taxes in Brazil induces the government to propose sweeping reforms that alter many aspects of the intricate tax structure. These proposals generated multidimensional conflicts: the emergence of many political cleavages simultaneously. I also compare the tax reform with two other reforms of the period: the reform of judiciary and administrative reform.
\end{abstract}


"Taxes are the price we pay for a civilized society,"

Oliver Wendell Holmes, Jr., juiz da Suprema Corte Americana.

"Deve-se considerar aqui que não há coisa mais difícil, nem de êxito mais duvidoso, nem mais perigosa, do que o estabelecimento de novas leis.

O novo legislador terá por inimigos todos aqueles a quem as leis antigas beneficiavam, e terá tímidos defensores nos que forem beneficiados pelo novo estado de coisas. Essa fraqueza nasce parte do medo dos adversários, parte da incredulidade dos homens, que não acreditam na verdade das coisas novas senão depois de uma sólida experiência. Daí resulta que os adversários, quando têm ocasião de assaltar, o fazem fervorosamente, como sectários, e os outros defendem sem entusiasmo, e periclita a defesa do Príncipe."

Nicolau Maquiavel, O Príncipe (cap. VI)

Divide et impera

Provérbio Romano 


\section{Índice}

Agradecimentos ....................................................................................................................... 7

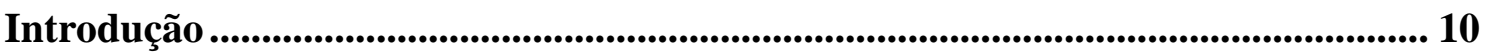

1 - A Questão Tributária no Brasil........................................................................ 16

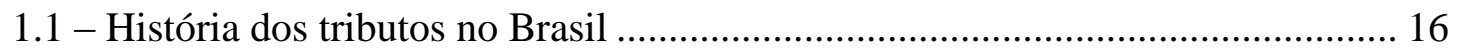

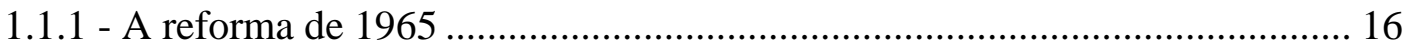

1.1.2 - A alteração nas alíquotas interestaduais ..................................................... 21

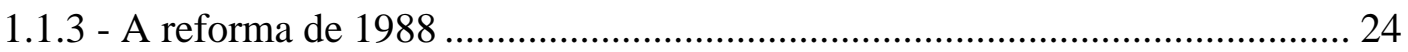

1.1.4 - Principais modificações de 1988 a 2008 ...................................................... 28

1.2 - A Questão Tributária no Brasil atual: um resumo ........................................... 31

1.2.1 - Problemas do ICMS: um resumo ........................................................................ 36

1.2.1.1 - Tributação na origem e dupla autoridade tributária ................................ 36

1.2.1.2 - Guerra Fiscal do ICMS .................................................................... 42

2- A Ausência de uma Reforma Tributária no Brasil: teorias explicativas ............. 46

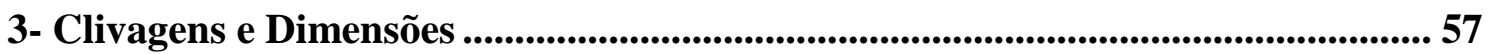

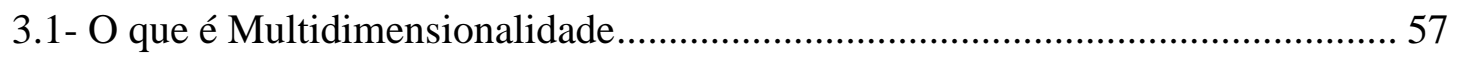

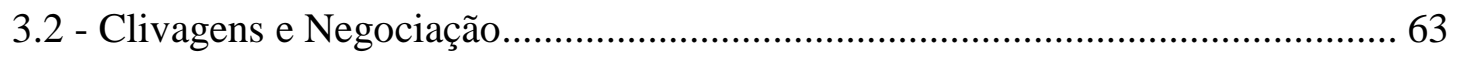

3.3- Clivagens e formação de preferências .............................................................. 70

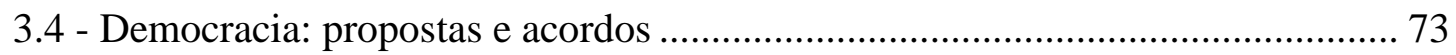

4- Propostas políticas em perspectiva comparada......................................................... 74

4.1 - Comparação entre propostas políticas: princípios teóricos ................................ 74

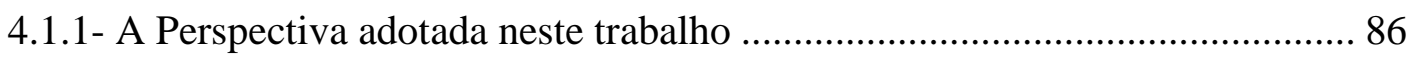

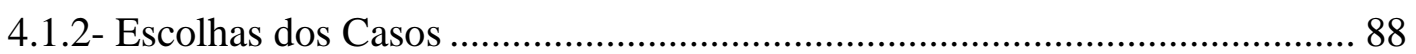

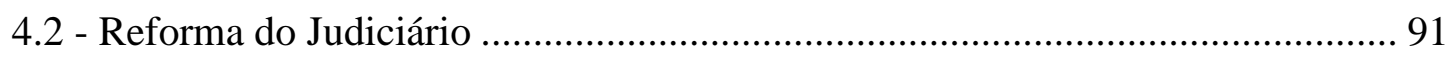

4.2.1 - Direitos Fundamentais .......................................................................... 94

4.2.2- Fortalecimento e Ampliação da Força Normativa da Justiça do Trabalho ... 94

4.2.3 - Reformulação da Justiça Militar .............................................................. 95

4.2.4- Justiça Descentralizada e Defensoria Pública............................................... 96

4.2.5- Modificação nas Competência e Direitos Jurisdicionais .............................. 96 
4.2.6- Aumento do poder da Cúpula do Judiciário ............................................... 97

4.2.7 - Regulamentação sobre os tribunais inferiores ............................................ 99

4.2.8 - A Estratégia Política da Reforma do Judiciário ......................................... 101

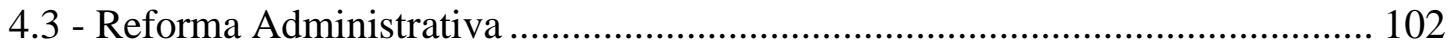

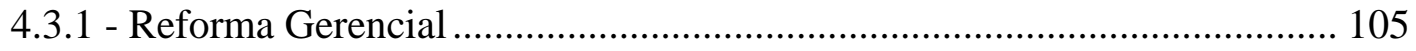

4.3.2 - Reforma dos Vencimentos dos Cargos Eletivos ........................................ 106

4.3.3 - Empresas Públicas ............................................................................... 108

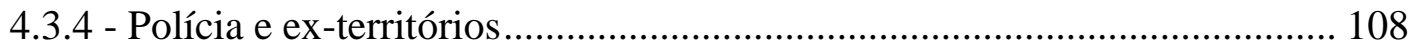

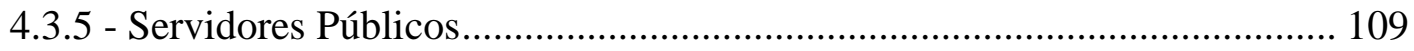

4.3.6 - A Estratégia Política da Reforma Administrativa...................................... 111

5 - Os nós críticos da reforma tributária ........................................................ 112

5.1 - Uma breve história das reformas tributárias pós-1988 ................................... 112

5.2 - Uma visão geral das reformas tributárias ........................................................ 117

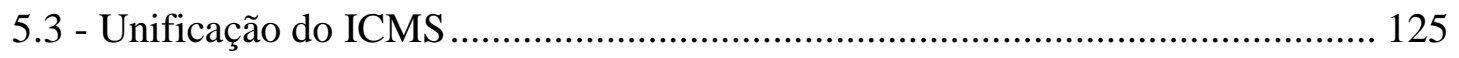

5.3.1 - Determinação das novas alíquotas (problema federativo). ........................ 125

5.3.2 - Determinação das novas alíquotas (carga tributária).............................. 127

5.4 - Fim das isenções fiscais estaduais (guerra fiscal) ......................................... 128

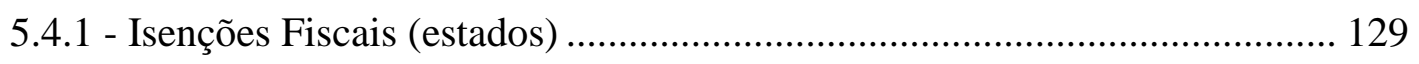

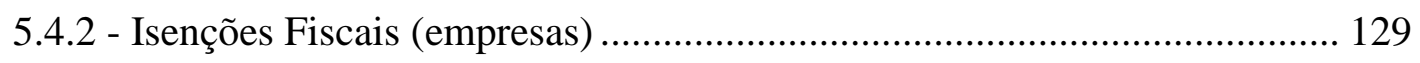

5.4.3 - Pequenos beneficiários do ICMS ........................................................... 131

5.4.4 - A Multidimensionalidade da unificação do ICMS ................................... 132

5.5 - Instituição do princípio do destino ................................................................. 133

5.5.1 - Questão origem/destino (distribuição do imposto).................................. 134

5.5 .2 - Origem/destino (petróleo e energia) ...................................................... 138

5.5.3 - Questão origem/ destino (cobrança do imposto). ..................................... 139

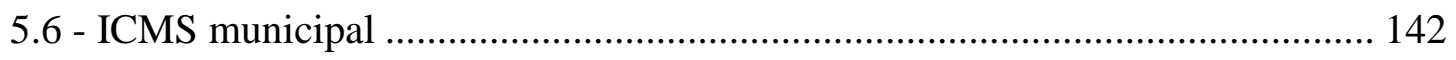

5.7 - Aumento da progressividade dos tributos ..................................................... 143

5.8 - Reformulação das vinculações constitucionais .............................................. 144

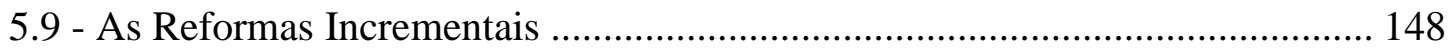

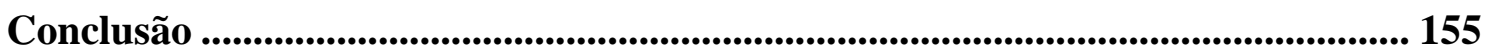

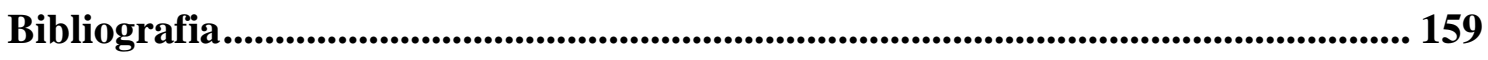

Anexo I: impostos cumulativos VS. Impostos sobre valor agregado..................... 165

Anexo II: princípio da origem atenuado ..................................................................... 168 


\section{Agradecimentos}

No início de 2004 eu estava determinado a conseguir uma iniciação científica. Havia me desiludido com a militância no movimento estudantil, que tinha dominado meus interesses durante os dois primeiros anos do curso de ciências sociais na USP. Eu queria entrar para o mundo acadêmico.

Mandei uma dezena de emails para professores, pedindo auxílio. Alguns professores me ignoraram, outros me trataram mal, alguns aceitaram conversar comigo e dar dicas, mesmo sem me dar oportunidade de pesquisa. Devo ressaltar o desprendimento dos professores Gildo Marçal Brandão, Cícero Araujo e Álvaro Comin, que fizeram comentários pertinentes sobre meu projeto, que, hoje vejo, não merecia ser levado a sério. Certo dia, fui visitar a professora Marta Arretche, com quem fazia uma disciplina. Lembro-me bem deste dia. Dia 13 de março de 2004. Ela estava de saída e eu a pequei na porta de sua sala. Falei que tinha interesse em pesquisar. Ela me perguntou: "você tem interesse em estudar a disputa fiscal entre os estados?". Pensei, durante um segundo, e disse, "sim, claro". Teria aceitado qualquer coisa. "Então passe no Departamento e se inscreva no programa institucional de iniciação científica”. Então eu pensei "Ué!? Só isto?".

Passaram-se seis anos e eu ainda estou no mesmo projeto. Pensei mil vezes em mudar, em estudar algo mais empolgante, mais revolucionário. Naquela época eu já tinha me apaixonado por assuntos que misturavam sociologia e economia, por influência dos cursos do professor Álvaro Comin, sobre sociologia do desenvolvimento latino-americano. Sonhava (e ainda sonho) em poder fazer um trabalho que ajude o país ou até mesmo o mundo; que traga justiça social, redução da miséria, desenvolvimento econômico, fortalecimento da democracia e da liberdade. Hoje vejo que já tinha encontrado a solução, mas não tinha percebido. Ela havia sido dada pela professora Marta Arretche, naquela noite de 2004, com aquela frase simples "você não quer estudar a disputa fiscal entre os estados?". Naquela altura eu nem sabia que havia uma disputa fiscal entre os estados.

Porém, a questão fiscal se mostrou mais estimulante do que parecera à primeira vista. Hoje posso afirmar. Nada irá ampliar mais a justiça social, reduzir a miséria, desenvolver a economia e fortalecer a democracia no curto e médio prazo do que a 
reforma tributária. Temos um dos piores e mais injustos sistemas de tributação indireta do mundo. Ele atrapalha as empresas, penaliza desproporcionalmente os pobres, favorece a corrupção e a criminalidade - pois empurra uma grande parte dos trabalhadores e dos empreendedores para a informalidade (leia-se "ilegalidade"). Desatar este nó é uma luta em que não me importaria em continuar travando por mais quantos anos fossem necessários para a vitória.

Gostaria de agradecer à imensa ajuda da minha orientadora, Marta Arretche, que nestes longos anos de convivência sempre me apoiou, sendo ao mesmo tempo crítica e elegante, profunda e concisa, profissional e amiga.

Também ajudaram muito os professores Mathew Taylor e Wagner Marcon Praluso, que fizeram comentários bastante pertinentes durante a banca de qualificação, ocasionando uma mudança nos rumos do trabalho.

Igualmente grato sou ao professor Fernando L. Abrucio, do qual fui aluno visitante, na Fundação Getúlio Vargas. Suas reflexões sobre a reforma administrativa, bem como sua personalidade aberta e prestativa, ajudaram muito a formar o capítulo 4 deste trabalho. Se faço críticas à sua tese de doutorado, não posso deixar de reconhecer que aquele foi um livro belíssimo.

Gostaria de agradecer a todos os professores do Departamento de Ciência Política e dos demais departamentos das ciências sociais por se dedicarem fortemente à ciência e à docência, proporcionando a mim e a muitos outros um ensino público e gratuito de grande qualidade.

Ajudaram-me na pesquisa Andrea Freitas e Danillo Buscatto Medeiros, ao disponibilizarem o banco de dados legislativo do Cebrap. Parabenizo todos membros do Cebrap por construírem e manterem este banco.

Agradeço igualmente a Paula Berbet e Natália Alfonso, que foram minhas auxiliares na digitação de trechos do Diário Oficial da Câmara dos Deputados. E a Vinícius Marques Pastorelli por varar noites comigo revisando o trabalho.

Gostaria de agradecer à minha família, que sempre me apoiou. A meu pai, Márcio José Junqueira, meu grande exemplo de trabalho e honestidade. À minha mãe, Maria de Fátima de Oliveira Junqueira, a criatura mais doce que eu já conheci. Aos meus irmãos, Hugo e Ricardo, por serem grandes amigos. E também aos meus avós e tios, que infelizmente não posso citar todos.

Gostaria de agradecer aos meus amigos, que substituíram minha família quando chegue a São Paulo, dez anos atrás. Quero agradecer à Patrícia, que sempre estará no 
meu coração. À João Alex, Leandro PC e Wilson, companheiros sempre dispostos a discutir sem perder a amizade, por mais divergências que existam. Aos meus companheiros de apartamento, Daniel e Diego, por me aturarem. Aos companheiros da gloriosa República de Santo Onofre, que me proporcionou os anos mais alegres de minha graduação: Denis, Frederico, Carlos Virtude, Daniel Vio, Sidney, Gabriel, Helio, Gustavo e a todos os membros da "população flutuante" da casa. Aos colegas de trabalho na Secretaria de Gestão Pública do Estado de São Paulo: Jorge, Daniel Araujo, Daniel Oliveira, Luiz, Maíra, Renata, Vanessa, Tereza, Wagner e a todos mais que não posso citar. Aos meus colegas de docência Daniel Teixeira e Alexandre Piero, por me substituírem quando eu precisava. Aos meus colegas do Departamento de Ciência Política, que tornavam a sala de informática um centro intelectual tão refinado quanto os cafés do quartier latin: André, Davi, Fabrício, Fernando, Francesca, Humberto, Ivan, Manoel, Natália, Olivia, Rodolfo e Vera.

Peço perdão, caso tiver esquecido alguém. 


\section{Introdução}

Suponha que você tenha uma casa. Ela já foi maravilhosa no passado, mas agora apresentas problemas graves de encanamento, fiação, mofo, pintura desgastada e goteiras no teto. Claramente ela precisa de reformas. E não apenas em um ou outro cômodo, mas na casa toda. Há anos você e sua família desejam fazer essa reforma. Mesmo com o orçamento apertado, vocês acham que podem espremer as economias para bancar estes consertos, que cada dia parecem ser mais urgentes. Mas há um problema: você não tem outra casa. Não há como mudar para a casa de parentes ou amigos. Morar em um hotel está fora de cogitação. Você definitivamente precisa da sua casa. Não pode sair dela, nem que seja por pouco tempo.

$\mathrm{Na}$ reunião familiar (sua família é muito democrática) todos concordam que é preciso fazer a reforma. Mas o consenso acaba por aí. Cada um defende sua prioridade. A filha não quer sair de seu quarto, onde passa longas horas conversando com as amigas pelo telefone e na internet. O filho quer ter preservado seu quarto, pois precisa estudar para o vestibular. A esposa acha que deve ser deve ser dada prioridade à fiação elétrica, pois ela pode causar acidentes. O pai acredita que é o encanamento danificado que causa o mofo e as goteiras, acreditando que a reforma tenha que ter este foco.

Os vizinhos, alguns especialistas em construção, sugerem à sua família modelos arquitetônicos altamente sofisticados. Alguns argumentam que outras casas vivem muito felizes com os modelos sugeridos. Outros argumentam que seus projetos são inovadores e revolucionários, e se esforçam para provar para sua família as grandes qualidades deles. Quando se reúnem, quase brigam.

Quanto mais se discute, mais parece que o certo é reformar toda a casa. Afinal, como vamos reformar a fiação sem mexer no encanamento? Como vamos reformar o quarto de um filho sem reformar o quarto do outro? A cozinha e o banheiro também precisam de consertos, dizem os membros da família. Porém, vocês só têm uma casa. Se o quarto de um filho é reformado, ele terá que se mudar para o quarto do outro. Se os quartos de ambos forem reformados, eles precisarão ir para o quarto do casal. Se a fiação estiver em reforma, a casa ficará sem luz, exigindo esforço e paciência da família que ficará à luz de velas e sem TV. A reforma dos encanamentos gerará transtornos no banheiro e na cozinha. 
Apesar do que pode parecer, nessas situações o pior a fazer é reformar a casa toda. As reformas produzem muita sujeita e pioram a infraestrutura da casa. Antes de melhorar, a situação vai piorar. Não se pode deixar que um membro da família sofra demasiadamente. Uma grande reforma traria muito sofrimento para a família toda. Apesar da imensa ansiedade por uma grande reforma, a solução só virá se for reformado um cômodo de cada vez. Somente assim as atividades normais da casa poderão continuar.

A família pode se reunir e pensar compensações pelos transtornos causados pela reforma (que será muito boa para todos, a longo prazo). Compensa-se a filha que ficou sem quarto com um vestido novo. Quando chegar a vez de reformar o quarto do filho, pode-se compensá-lo com um computador. Todos combinarão de fazer silêncio para não atrapalhá-lo nos estudos. Compram-se jogos de tabuleiro para as noites com pouca luz. De qualquer maneira, todas essas medidas só são viáveis, reformando um cômodo de cada vez. Reformar a casa toda levaria a um sofrimento demasiadamente pesado e ficaria difícil compensar a todos.

Os articuladores da reforma do sistema tributário no Brasil, no entanto, não tiveram esta prudência. O sistema tributário é um dos nós do desenvolvimento econômico e social do país. Ele precisa de reformas. Apesar do amplo consenso de que os tributos são economicamente ineficientes e socialmente injustos, sucessivos governos falham em alterá-lo.

O governo Fernando Henrique Cardoso enviou ao congresso uma proposta de reforma tributária (Proposta de Emenda Constitucional Número 175 de 1995) que, após quatro anos de discussões, foi aprovada por unanimidade na comissão especial constituída para analisar seu mérito. Contudo, ela não foi votada pelo plenário da Câmara dos Deputados até o final do governo FHC, em 2002. A reforma foi abandonada pelo Executivo e pelas lideranças políticas, sendo finalmente retirada pelo Executivo no início de 2003. O governo Luiz Inácio Lula da Silva enviou outra proposta de reforma tributária ao Congresso: a PEC 41/2003. Ela foi aprovada pela Câmara dos Deputados em setembro de 2003, mas não foi aprovada pelo Senado. As lideranças políticas do governo tentaram retomar as discussões em 2004 e então propuseram as PECs 255, 284 e 294/2004, mas todas elas malograram ainda na Comissão Especial. Em 2008 o governo Lula enviou outra proposta ao parlamento: a PEC 233/2008, apensada à PEC 31/2007. Ela foi aprovada pela comissão especial em novembro do mesmo ano e ainda aguarda votação no plenário da Câmara dos Deputados. As chances 
de essa proposta ser aprovada são mínimas, uma vez que seu formulador e principal policy advocate, Bernard Appy ${ }^{1}$, abandonou o governo em agosto de 2009.

Em resumo: as propostas de reforma tributária sofrem de crônica paralisia decisória.

Quais seriam os motivos dessa paralisia decisória? Por que o consenso de que o sistema tributário sofre de inúmeras mazelas não é motivo suficiente para que ele seja alterado? Será que a incapacidade de aprovar a reforma tributária demonstra uma falha de nosso sistema político?

O próprio presidente Lula declarou publicamente na reunião do Conselho de Desenvolvimento Econômico e Social, dia 15/09/2009:

Eu confesso a vocês que essa discussão sobre política tributária, para mim, está ficando uma coisa velha e arcaica, por que só eu já mandei duas [propostas] para o Congresso nacional e não aconteceu absolutamente nada. E eu não posso mandar a terceira, não só porque eu não tenho mais tempo, mas por que eu não acredito. A verdade é que uma parte da sociedade não quer reforma tributária. Por que, se quisesse, ela já teria acontecido. ${ }^{2}$ [grifos nossos]

Em entrevista à revista ISTO É, fazendo um balanço de seus oito anos de mandato, Lula completou ${ }^{3}$ :

Isto é: Nestes oito anos o senhor se arrepende de algo que não fez?

Lula: Talvez nesses cinco meses de reflexão que eu pedi para vocês [depois do mandato], vá surgir muita coisa. Eu fiz uma proposta de política tributária que todo mundo dizia que precisava. Fiz uma em consenso com os governadores, com todos os empresários, com todos os dirigentes sindicais, com todos os líderes partidários e ela não foi aprovada. Mandei para o Congresso Nacional e não foi votada. Então tem um desgraçado de um inimigo oculto que está trancado em algum armário e não permite que se vote a reforma tributária.

\footnotetext{
${ }^{1}$ Appy foi funcionário do Ministério da Fazenda de 2003 a 2009. Ocupou os cargos de Secretário Executivo, Secretário de Política Econômica e Secretário de Reformas Econômico-Fiscais.

2 'Não acredito mais em reforma tributária', afirma presidente. UOL notícias, disponível em: http://noticias.uol.com.br/ultnot/multi/2009/09/15/0402386ADC813366.jhtm?nao-acredito-mais-emreforma-tributaria-afirma-presidente-0402386ADC813366 (acessado em 10/10/2009).

${ }^{3}$ Revista ISTOÉ. Edição 2126, de 11/10/2010, pag. 54. Disponível parcialmente em http://www.istoe.com.br/reportagens/93552_O+MOMENTO+DE+LULA (acessado em 22/11/2010).
} 
Este trabalho irá mostrar que o inimigo não está oculto. Ele só é um pouco difícil de entender. Se minha argumentação estiver correta, a resposta para o dilema tributário não está na estrutura política, mas na estratégia dos governos. A onipresença do fenômeno tributário ${ }^{4}$ - e a ampla insatisfação que ele gera - induzem o governo a propor reformas amplas, que alteram muitos aspectos da intrincada estrutura tributária. Essas propostas acabam gerando conflitos multidimensionais, ou seja, o aparecimento de muitas clivagens políticas simultâneas. A multidimensionalidade é uma característica crônica das propostas de reforma tributária do Executivo. Esse é o segredo de seu fracasso. Apesar de os custos de transação do sistema político brasileiro não serem particularmente altos (Figueiredo \& Limongi, 1999; Limongi, 2006), há um limite ao número de negociações que os reformadores podem fazer ao mesmo tempo. Em geral, as disputas políticas em torno das propostas são tão complexas que nenhum ator é capaz de prever com exatidão o resultado do conflito. Existe um momento no qual o próprio governo resolve retirar ou abandonar a proposta, temendo os efeitos das muitas concessões e reformulações que foram feitas para mudar o projeto original. Foi isto o que aconteceu na PEC 175/1995, quando o governo se recusou a votar no plenário a proposta totalmente reformulada na comissão especial. Semelhante foi o caso da PEC 41/2003, onde o governo resolveu aprovar apenas a prorrogação da CPMF e da DRU; além de alguns pontos menos conflituosos, como o princípio da noventena, a constitucionalização da Lei Kandir e um tratamento privilegiado às pequenas empresas. Similar, ainda, é o caso da reforma atualmente em tramitação (PEC 233/2008 e 31/2007), que está desde o final de 2008 para ser votada em plenário, mas não obtém consenso nem mesmo dentro da base governista.

O resumo do argumento aponta para a seguinte corrente de causação:

\section{Onipresença}

da insatisfação $\rightarrow$ Reformas Amplas $\rightarrow$ Multidimensionalidade $\rightarrow$ Paralisia tributária

decisória

Os sistemas tributários em geral, particularmente os que estão sob regimes democráticos, são avessos a reformas amplas (Bird, 1992, Tanzi e Zee, 2000 Mahon,

\footnotetext{
${ }^{4}$ O relator da PEC 41/2003, Dep. Virgílio Guimarães (PT-MG) declarou: "Nessa experiência de elaboração coletiva pude perceber a onipresença do fenômeno tributário na vida cotidiana dos brasileiros, o desconforto generalizado que prevalece em nosso País em relação à injustiça tributária e o interesse enorme das pessoas em melhorar esse estado de coisas." CAMARA DOS DEPUTADOS, Notas Taquigráficas da Comissão especial da PEC 41/2003, dia 18/08/2003. Disponível em: http://www2.camara.gov.br/comissoes/temporarias/especial/encerradas/pec04103/notas/Pec04103nt18080 3.pdf (acessado em 10/10/2009)
} 
2004, Melo, 2005). Eles são altamente path dependent. Mesmo um sistema extremamente mal avaliado, como o brasileiro, não pode ser reformulado todo de uma vez. Não podemos paralisar o sistema, reformá-lo, testar a eficácia das alterações e depois religá-lo. Não temos outra casa para morar neste meio tempo. O presidente, os governadores e os prefeitos não querem nem pensar na possibilidade de verem os funcionários civis e as forças armadas, sem receber salários, diante de seus palácios. Ou então, os doentes, morrendo por falta de remédios. Ou ainda, os aposentados sem receber. O sistema tributário é uma máquina que nunca pode parar ou mesmo ter perdas graves de eficiência, pois os gastos públicos são inflexíveis "para baixo" no Brasil.

Contudo, o nó tributário pode ser desfeito com uma nova estratégia política do governo que priorize reformas graduais e constantes, como sinalizado na figura abaixo:

\section{Onipresençada Consciência Propostas insatisfação + do problema da $\rightarrow$ incrementais $\rightarrow$ Reformas incrementais tributária multidimensionalidade}

Tende em mente essas questões, o texto está organizado da seguinte forma. No primeiro capítulo é feito um resumo da questão tributária no Brasil. Mais especificamente, analisa-se a evolução do sistema de impostos desde a reforma da ditadura militar, em 1967, até os anos 90, mostrando como ele foi gradualmente perdendo qualidade. No segundo capítulo, examina-se as versões da literatura política sobre por que não se faz uma reforma tributária no Brasil. No terceiro capítulo, demonstram-se as bases teóricas da hipótese principal deste trabalho: a teoria espacial do voto e os problemas gerados pela multidimensionalidade. No quarto capítulo, se analisa a trajetória de duas reformas que, ao contrário da reforma tributária, foram aprovadas pelo parlamento: a reforma administrativa e a reforma tributária. Ao final, ter-se-á demonstrado que, apesar de serem reformas extensas, elas não antepunham à solução tantas clivagens políticas quanto a mudança nos tributos. No quinto capítulo, há uma exegese da reforma tributária, onde demonstra o quão multidimensional ela era e todos os problemas que isso gerou. A conclusão, finalmente, sintetiza os argumentos.

Os assuntos tributários são conhecidos como complexos e áridos para os não especialistas. Levando isso em conta, o texto está construído para ser autoexplicativo, mesmo para quem não é familiarizado com o tema. Assim, para aliviar o texto de detalhes técnicos, foram colocados dois anexos explicativos ao final do trabalho. Um 
explica a diferença entre "impostos cumulativos" e "impostos sobre o valor agregado"; o outro explica como funcionam os impostos sobre o consumo divididos entre dois estados, como o ICM e o ICMS. 


\section{1 - A Questão Tributária no Brasil}

Esta seção tem por objetivo expor o tema deste trabalho: descrever a "questão tributária no Brasil”. Primeiramente, será feita uma pequena exposição histórica da evolução dos impostos a partir da segunda metade do século XX. E, em seguida, há um diagnóstico do estado atual do sistema tributário.

\section{1 - História dos tributos no Brasil}

\subsection{1 - A reforma de 1965}

A reforma tributária de 1965 impulsionou uma grande modernização da estrutura tributária vigente desde 1946. Houve uma ampla racionalização administrativa do sistema tributário, uma melhor definição dos campos de tributação, os impostos em cascata foram eliminados e substituídos por impostos sobre valor agregado ${ }^{5}$. No campo dos tributos diretos foi ampliado o imposto de renda, com a criação do imposto de renda sobre pessoa jurídica (ITPJ) (Cossio, 2000) (Varsano, 1996).

Essa reforma foi fundamental para a continuidade do modelo desenvolvimentista brasileiro, pois, além de melhorar a qualidade do sistema tributário, estancou grande parte do déficit público que ocorria até então. Segundo Varsano (1996):

$O$ apoio à industrialização e ao desenvolvimento regional gerou um crescimento das despesas que não pode ser acompanhado pelo das receitas. Assim, a despesa do Tesouro Nacional, ao redor de $8 \%$ do PIB no final da década de 40, elevou-se para $11 \%$ a partir de 1957 e, no início dos anos 60, atingiu a marca dos $13 \%$ do PIB. (..) Como as despesas continuaram a crescer aceleradamente, o déficit do Tesouro ultrapassou, em 1962 e 1963, a marca dos 4\% do PIB. Não existindo uma estrutura institucional que possibilitasse o seu financiamento por

\footnotetext{
${ }^{5}$ O anexo I faz uma breve explicação sobre como funciona os impostos cumulativos e sobre valor agregado (IVA), bem como as conseqüências destes dois sistemas.
} 
meio de endividamento público, o déficit foi coberto quase que totalmente através de emissões. A taxa de inflação anual, que era da ordem de 12\% em 1950 e já atingia 29\% em 1960, elevou-se rapidamente para 37 e $52 \%$ nos anos seguintes e saltou para $74 \%$ em 1963. (pag. 7)

A receita, que atingiu um mínimo de $8,6 \%$ do PIB em 1962, recuperou-se com as mudanças feitas pelo regime militar e em 1965 já atingia 12\% do PIB. Do início dos anos 70 até 1978 , a carga tributária se manteve acima de $25 \%$ do $\mathrm{PIB}^{6}$. Os documentos mais importantes dessa reforma são a Emenda Constitucional 18/65 (que foi mantida pela Constituição de 1967) e o Código Tributário Nacional, aprovado em 1966 (e ainda em vigor).

Na tabela I pode-se comparar as principais modificações das reformas de 1946, de 1965-7 e 1988. Como se pode verificar, a reforma de 1965-67 não alterou a estrutura dos dois principais impostos sobre propriedade, o Imposto sobre Propriedade Territorial Urbana (IPTU) e o Imposto Territorial Rural (ITR) ${ }^{7}$. A única mudança na estrutura de tributação sobre a propriedade foi a fusão do antigo Imposto Municipal sobre a Transmissão de Bens Imóveis Intervivos (ITBI-IV) e do Imposto de sobre Transmissões Causa Mortis (ITBI-CV) no Imposto sobre a Transmissão de Bens Imóveis (ITBI).

Além disso, a base de tributação dos impostos sobre renda se ampliou consideravelmente com a instituição do Imposto de Renda Pessoa Jurídica (IRPJ). Assim, a reforma de 1967 estabeleceu tanto os impostos sobre as rendas corporativas, quanto sobre as rendas financeiras, que antes eram tributadas indiretamente pelo Imposto sobre Negócios e Economia. Ou seja, considerados em conjunto todas as mudanças que introduziu, a IRPJ causou uma sensível ampliação da participação dos impostos diretos na carga tributária.

No entanto, a maior modificação da reforma de 1967 ocorreu nos impostos indiretos sobre a produção e comercialização de mercadorias. Dentre as principais modificações podemos destacar o fim da cumulatividade de uma série de impostos e sua

\footnotetext{
${ }^{6}$ Durante a década de 80, a crise fiscal abalou as finanças do governo e houve uma ligeira redução do percentual do PIB apropriado por impostos. Mais detalhes ver Varsano et alli $(1998$, pg, 41)

7 O ITR era um imposto federal porque muitas prefeituras não tinham estrutura de administração tributária para arrecadar o imposto. Trata-se de um dos impostos mais difíceis de serem cobrados e mais propícios à sonegação no Brasil. Os legisladores preferiram deixar o imposto sob responsabilidade da União, mas estabeleceram que ela deveria transferir a arrecadação às prefeituras.
} 
substituição por impostos sobre valor agregado. A reforma fundiu os antigos Impostos sobre o Consumo (IC) e sobre Vendas e Consignações (IVC), ambos cumulativos, aos recém-criados "Imposto sobre Circulação de Mercadorias (ICM)" e "Impostos sobre Produtos industrializados (IPI)", sendo o primeiro estadual e o segundo federal.

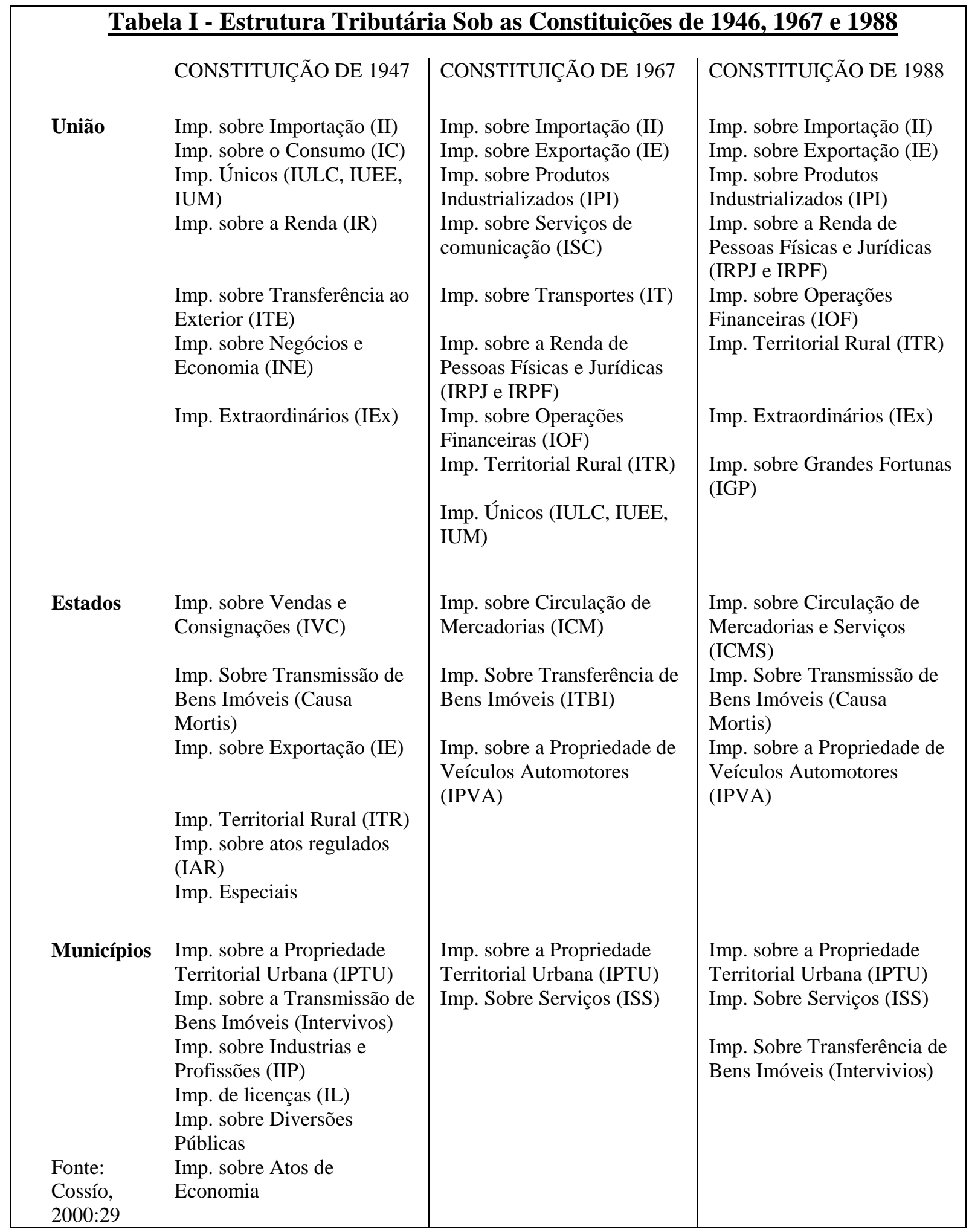


Além disso, os vários impostos sobre serviços municipais (Impostos sobre Indústrias e Profissões, Imposto de licença, Impostos sobre diversões públicas etc) também foram substituídos por um único Imposto sobre Serviços (ISS).

Corroborando a teoria econômica do federalismo fiscal (Cossio, 2000), os tributos com menor grau de vinculação entre contribuinte e beneficiários - impostos sobre fatores móveis - foram usados para financiar os fundos de redistribuição regional. A constituição de 1967 determinava que 10\% do IR e do IPI deveriam ser destinados ao Fundo de Participação dos Estados (FPE) e 10\% para o Fundo de participação dos Municípios (FPM).

A tabela II resume as transferências intergovernamentais em 1967 e 1989.

\section{Tabela II}

Transferências Inter-Governamentais nas Constituicões de 1967 e 1988

CONSTITUIÇÃO DE 1967

\section{União para Estados}

Fundo de Participação dos Estados, $10 \%$ do IR e do IPI

Fundo Especial, 2\% do IPI e do IR (a partir de 1968)

IUEE, IUM, IULC, IT, 50\%, 70\%, 40\% e 50\%, respectivamente.

\section{CONSTITUIÇÃO DE 1988}

Fundo de Participação de Estados, 21,5\% do IR e do IPI

IPI proporcional às Exportações, 10\% da arrecadação

Impostos que a União institui no exercício de competência residual, $20 \%$

IR Retido na fonte

Fundos Regionais (FNE, FNO, FCO), 3\% do IR e do IPI

\section{União Para municípios}

Fundo de Participação dos Municípios, 10\% do IR e do IPI

IUEE, IUM, IULC, IT, $10 \%, 20 \%, 20 \%$ e $20 \%$, respectivamente

ITR, $100 \%$ da arrecadação

IR Retido na Fonte

\section{Estados para municípios}

$20 \%$ do ICM

$50 \%$ do IPVA

$50 \%$ do ITBI

Fonte: Cossio, 2000 (APUD Afonso et alii, 1989)
Fundo de Participação dos Municípios, 22,5\% do IR e do IPI

IR Retido na Fonte

ITR, $50 \%$ da arrecadação

$25 \%$ do ICMS

$50 \%$ IPVA

$25 \%$ dos recursos recebidos pelo IPI proporcional às exportações

$25 \%$ dos recursos recebidos pelos fundos regionais 
Cabe ressaltar que, apesar de a Constituição de 1967 ter aumentado as transferências para estados e municípios, o Regime Militar logo reduziu esses valores. Além disso, a liberdade para os entes subnacionais legislarem sobre seus impostos era mínima. Segundo Varsano (1996, pg. 10)

\begin{abstract}
Após completada a reforma, os estados sofreram limitações adicionais ao seu poder de tributar e, já em 1968, no auge do autoritarismo, também as transferências foram restringidas. O Ato Complementar $n^{\circ} 40 / 68$ reduziu, de 10 para $5 \%$, os percentuais do produto da arrecadação do IR e do IPI destinados aos Fundos de Participação dos Estados e dos Municípios (FPE e FPM), respectivamente. Em contrapartida, criou o Fundo Especial (FE), cuja distribuição e utilização dos recursos eram inteiramente decididas pelo Poder Central, destinando a ele $2 \%$ do produto da arrecadação daqueles tributos. $O$ Ato também condicionou a entrega das cotas dos fundos a diversos fatores, inclusive à forma de utilização dos recursos. A autonomia fiscal dos estados e municípios foi reduzida ao seu nível mínimo, aí permanecendo até $1975^{8}$.
\end{abstract}

A distribuição federativa dos instrumentos tributários se concentrou nas mãos da União. A reforma tributária foi pensada para possibilitar o máximo de crescimento econômico. A centralização tributária possibilitou ao governo federal a liberdade e flexibilidade necessária para criar incentivos para o desenvolvimento.

Cabe ressaltar que o "lado negro" dessa verdadeira pérola tecnocrática do regime militar foi um grande aumento da regressividade do sistema tributário devido ao aumento da tributação indireta (Varsano, 1996, pg. 10-14), o que até hoje permanece como uma marca do sistema tributário brasileiro.

A elevada centralização do poder fỉscal na União também era evidenciada quando se observa que a União podia definir alíquotas e incentivos fiscais para impostos que não estavam sob sua competência (Varsano, 1981). Era atribuição da União regular o principal tributo dos estados: o ICM. Os estados podiam modificar alguns aspectos do ICM, mas estas modificações eram fortemente controladas pela União. Além disso, a Lei Complementar 24 de 1975 (LC 24/75), que regulamentou o ICM, determinou que as alíquotas deviam ser uniformes por região e que a administração do imposto, bem como

\footnotetext{
${ }^{8}$ A União gradualmente voltou a aumentar os recursos do FPE e do FPM a partir d 1975. Em 1985 os valores eram de $14 \%$ e de $17 \%$, respectivamente.
} 
desonerações, concessões e benefícios fiscais, deveriam ser aprovadas por unanimidade no Conselho de Política Fazendária (CONFAZ) ${ }^{9}$.

A partir da segunda metade da década de 70, criou-se um consenso de que um dos efeitos da reforma de 1965-67 foi criar uma excessiva centralização da carga tributária na União. Essa centralização causava a insuficiência financeira e a dependência dos níveis locais de governo, obrigados a recorrer cada vez mais à transferências intergovernamentais voluntárias.

\subsection{2 - A alteração nas alíquotas interestaduais}

Um fato importante ocorrido entre 1966 e 1988 foi a alteração das alíquotas interestaduais.

Quando o ICM foi instituído, na Emenda 18 de 01/12/65, ele era um imposto com alíquota uniforme de $15 \%$ em todo o território nacional. Não havia distinção entre as operações internas e as interestaduais ${ }^{10}$. Todo o imposto pertencia ao estado de origem das mercadorias. Mas esta situação durou pouco. Já em 10 de março de 1967, o CONFAZ instituiu o "Convênio de Natal", que determinou que as alíquotas das regiões Norte e Nordeste seriam de $18 \%$. A região Centro-Oeste seguiu o mesmo caminho em 7 de junho de 1967, no "Convênio de Cuiabá". Os argumentos para esta alteração eram: (a) o aumento das transferências federais não foram suficientes para compensar as perdas dos estados pobres com o fim do IVC e (b) o ICM isentou os produtos industrializados nas exportações, gerando custos adicionais que as alíquotas não cobriam $^{11}$.

Em março e abril de 1968, as regiões do Sul e Sudeste aumentam sua tributação para 17\%, mas só para as alíquotas internas. As alíquotas interestaduais foram mantidas em 15\%. Ironicamente, foram as regiões Sul e Sudeste que criaram o sistema de

\footnotetext{
${ }^{9}$ O CONFAZ é um órgão que reúne todos os secretários estaduais de fazenda, mais o ministro da fazenda (este último sem direito a voto).

${ }^{10} \mathrm{O}$ anexo II explica como funciona o sistema do imposto sobre o consumo dividido entre dois estados.

${ }^{11}$ Ao que tudo indica, a perda de arrecadação com a instituição do ICM simplesmente não ocorreu. $\mathrm{O}$ fato de o ICM, ao contrário do IVC, ser não cumulativo foi mais do que compensado pelo crescimento econômico, a melhoria da arrecadação e o aumento das alíquotas. Para mais detalhes, ver longo Coelho (1980) e Longo (1981).
} 
tributação parcial no destino, sendo que hoje estas mesmas regiões resistem à tributação no destino.

Em 1970, após apenas cinco anos de instituição do ICM, o Senado editou uma resolução (Resolução do Senado 65/70) que determinava que as alíquotas interestaduais e de exportação seriam gradualmente diminuídas até chegar em 13\% em 1974. Assim surgia a política de alíquotas interestaduais menores que as internas, fazendo com que o imposto recolhido nas operações interestaduais fosse dividido entre o estado de origem e o estado de destino. Segundo Baratto (2006), estava "oficializada" a adoção de alíquota interestadual inferior à interna. A alíquota de exportação permaneceu em 13\% até o advento da LC 87/96 [Lei Kandir]" (Baratto pg. 111).

Uma vez mudado o status quo, o sistema de alíquotas interestaduais menores que as internas se consolidou. Novamente o Senado editou uma resolução, em 1976, que previa nova redução das alíquotas interestaduais para 11\%. O CONFAZ ampliou ainda mais a queda da alíquota através de convênio. Legalmente, apenas o Senado podia estabelecer alíquotas interestaduais. Mas o CONFAZ podia estabelecer reduções na base de cálculo, o que tem o mesmo efeito na prática. Apesar do Estado de São Paulo se opor a reduções adicionais na alíquota ${ }^{12}$, ele foi pressionado por decisões judiciais que estavam determinando que a alíquota interestadual deveria ser aplicada também a não contribuintes (o que inclui os consumidores finais). Segundo Baratto (2006, pg. 112), "pressionados pela redução nas alíquotas interestaduais, representantes do estado de São Paulo na COTEPE/ICMS ${ }^{13}$ aceitaram reduzir ainda mais a alíquota interestadual nas operações com destino ao N/NE/CO, mas não para o S/SE (o Espírito Santo ainda integrava a região Sudeste)". Em troca, o CONFAZ estabeleceu uma resolução que determinava que os não contribuintes teriam que pagar as alíquotas internas, não as interestaduais. Estava então constituída a política de alíquotas interestaduais diferenciadas por região.

O argumento para a redução das alíquotas interestaduais era basicamente redistributivo. Seu objetivo era diminuir o desequilíbrio no comércio que a tributação na origem gera. Como o tributo pertence ao estado que produz as mercadorias, os estados industrializados têm uma arrecadação proporcionalmente maior que o seu consumo interno, enquanto os estados não industrializados têm uma arrecadação

\footnotetext{
${ }^{12}$ Como dito acima, as resoluções do CONFAZ têm que ser aprovadas por unanimidade.

${ }^{13}$ Esta é uma das comissões do CONFAZ
} 
proporcionalmente menor que seu consumo doméstico. A redução das alíquotas interestaduais visava a transferir parte do imposto para o estado de destino diminuindo este desequilíbrio.

O objetivo redistributivista pode ser entrevisto na justificativa do Projeto de Resolução do Senado (PRS) número 98 de 1979:

As alíquotas do ICM devem reaproximar-se, ao menos parcialmente, dos percentuais vigentes em 1969, passando a 16\%, para as operações internas e de exportação. No que tange às interestaduais, deverão ser diferenciadas, ou seja: $8 \%$ nas operações destinadas aos estados das regiões Norte, Nordeste e Centro-Oeste, e 12\% quando o destino for os estados das regiões Sul e Sudeste. Essa diferenciação de alíquota interestadual visa à redução das desigualdades regionais, constituindo-se em eficiente instrumento de redistribuição de renda [grifo nosso].

Em 10 de março de 1980, o CONFAZ aprovou o Convênio 01/80, que renovava o princípio de alíquotas interestaduais reduzidas e diferenciadas por região. Ele determinava que as alíquotas interestaduais deveriam permanecer em $11 \%$ nas regiões $\mathrm{N} / \mathrm{NE} / \mathrm{CO}+\mathrm{ES}^{14}$ e serem gradualmente reduzidas para $9 \%$ para as regiões $\mathrm{S} / \mathrm{SE}-\mathrm{ES}^{15}$. O convênio teria que ter sido aprovado por todos os estados para entrar em vigor, mas o Rio Grande do Sul não ratificou o acordo. Diante deste fato, a presidência enviou (e aprovou) um projeto ao Senado que instituía estas alíquotas por resolução ( $R S$ 07/80). Estes valores permaneceram até 1984, quando a Emenda Passo Porto (EC 23/83) aumentou as alíquotas interestaduais das regiões N/NE/CO+ES para $12 \%$.

Em 1989, o Senado modificou novamente as alíquotas interestaduais (RS 22/89), desta vez do recém-instituído ICMS. As alíquotas das regiões N/NE/CO+ES seriam mantidas em $12 \%$, enquanto as alíquotas das regiões S/SE-ES seriam diminuídas para $7 \%$.

\footnotetext{
${ }^{14}$ Esta sigla significa "Norte/Nordeste/Centro-Oeste mais o estado do Espírito Santo".

15 "Sul/Sudeste", menos o estado do Espírito Santo".
} 


\subsection{3 - A reforma de 1988}

A reforma tributária de 1988 ocorreu dentro de um contexto reformista maior, que foi a elaboração da Constituição de 1988. Ao contrário da reforma de 1965-67, que foi elaborada por técnicos de gabinete de um regime autoritário, a reforma de 1988 foi elaborada por políticos em um contexto de ampla democracia e participação social. Por isso, a reforma de 1988 foi mais focada em objetivos redistributivos do que em eficiência econômica. Segundo Varsano (1996)

Conseguiu-se mediante esse procedimento [a constituinte] promover o debate mais amplo de que se tem notícia na história do Brasil. Mas o processo, ímpar e não testado, tinha riscos altos. A dificuldade de coordenar um processo dessa envergadura e o prazo muito curto preestabelecido para ele - e tardiamente prorrogado diversas vezes -acabaram por vitimar o projeto de Estado que, ao final, foi impresso na Constituição promulgada em 5 de outubro de 1988. (pg. 13).

A crítica à centralização do sistema anterior, somada ao processo de redemocratização do país, em que a descentralização foi associada à democracia, fez com que o principal objetivo da reforma de 1988 fosse a redefinição das competências tributárias.

A descentralização tributária ocorreu mediante dois mecanismos: por um lado (1), ampliou-se a porcentagem de tributos federais repassados aos FPE e ao FPM, de maneira que esses fundos passaram a dispor de $21,5 \%$ e $22,3 \%$, respectivamente, do IR e do IPI (ver tabela II). Foi, também, estabelecida uma cláusula, que determinava que todo novo imposto criado pela União deveria ter um repasse semelhante para estados e municípios. Por outro (2), os tributos estaduais foram fortalecidos e os estados dispuseram de maior autonomia sobre eles. Foi suprimida a faculdade, atribuída pela Constituição de 1967 à União, de impor condições ou restrições aos entes subnacionais pelos recursos das transferências do FPE e do FPM. Nesse processo, os cofres municipais foram particularmente beneficiados, pois além da já mencionada ampliação do FPM, eles tiveram aumentada sua parcela de transferências do ICMS de $20 \%$ para $25 \%$. 
Também foi criado um fundo composto de 10\% do IPI que seria distribuído aos estados conforme sua participação nas exportações. A criação do fundo correspondia a uma reivindicação antiga dos estados exportadores. Visava ressarcir as perdas que eles tiveram com a desoneração das exportações dos produtos industrializados por ocasião da instituição do ICM em 1965.

O fundo especial foi extinto. Contudo, uma parcela maior que seu valor (3\% do IR e do IPI) foi destinada a programas de desenvolvimento das regiões Norte, Nordeste e Centro-Oeste através de instituições financeiras federais de caráter regional.

Os impostos federais únicos (Imposto Único sobre Lubrificantes e Combustíveis IULC, Imposto Único sobre Energia Elétrica - IUEE e Imposto Único sobre Mineração - IUM), mais o Imposto sobre Transportes (IT) e o Imposto sobre Serviços de Comunicação (ISC) foram incorporados à base do antigo ICM, criando assim o maior imposto do país, o Imposto sobre Operações Relativas à Circulação de Mercadorias e sobre Prestações de Serviços de Transporte Interestadual, Intermunicipal e de Comunicação.

O ICMS, doravante uma responsabilidade exclusiva dos estados, acabou tendo uma base tão ampla que se tornou responsável por mais de um quarto da arrecadação geral de impostos no país ${ }^{16}$. A União ficou com poucos instrumentos para intervir sobre sua regulamentação. A nova Constituição proibiu, por exemplo, que a União concedesse isenções ou concessões fiscais com os tributos subnacionais, faculdade que existia na Constituição anterior. Essas medidas, entre outros efeitos, permitiram que os estados pudessem usar o sistema tributário para atrair investimentos, abrindo espaço para a guerra fiscal ${ }^{17}$.

Outro detalhe. As alíquotas interestaduais do ICMS foram reduzidas para 7\% nas regiões S/SE-ES, fazendo com que os estados mais pobres (região N/NE/CO+ES) ficassem com uma parte maior do tributo no comércio entre estados. No entanto, esse tipo de rateio deixou de ser aplicado ao ICMS sobre energia elétrica e derivados de

\footnotetext{
${ }^{16}$ A arrecadação do ICMS em 2002 foi cerca de R\$ 103,999 bilhões, em valores correntes. Enquanto a arrecadação tributária total do setor público foi cerca de R \$353,179 bilhões. Para se ter uma idéia do peso deste tributo, o segundo maior imposto em termos de arrecadação é o IRPJ que arrecadou mais de $\mathrm{R} \$ 39,787$ bilhões em 2002. Se também considerarmos as contribuições sociais a hegemonia do ICMS cai um pouco, mas continua impressionante. A maior contribuição social é a Cofins que arrecadou $\mathrm{R} \$ 50,855$ bilhões em 2002 (IBGE, 2003)

${ }^{17}$ Os primeiros registros de uso dos sistemas tributários para a atração de empresas datam do início dos anos 80. Ou seja, a guerra fiscal se iniciou com a volta da eleição dos governos estaduais pelo voto direto em 1982, mesmo com a legislação restritiva da Constituição de 1967.
} 
petróleo, que, no caso, passou a ficar integralmente com o estado de destino da mercadoria $^{18}$.

A reforma também produziu algumas pequenas mudanças com vistas a aumentar a arrecadação e a progressividade dos impostos sobre a propriedade. Criou-se o Imposto sobre Grandes Fortunas (IGP) ${ }^{19}$, e se separou de novo o ITBI em ITBI-IV e ITBI-CM, possibilitando certa recuperação de progressividade. No entanto, a maior mudança nos impostos sobre propriedade ocorreu no ITR. Apesar de ele continuar sendo um imposto federal, com transferência automática para os municípios, ele passou a ser um imposto de caráter regulatório. Seu objetivo consistia, agora, em mudar a estrutura fundiária brasileira, punindo a grande propriedade improdutiva. As alíquotas do imposto passaram a ser proporcionais ao tamanho da propriedade e inversamente proporcionais à área produtiva. Contudo, ele continuou a ser um dos impostos menos produtivos, pois demanda onerosa estrutura de cobrança e é de fácil sonegação.

Além da descentralização, a Constituição de 1988 criou outra inovação: o Orçamento da Seguridade Social. Ele visa financiar as atividades típicas de bem-estar social: saúde, previdência e assistência social. Ele é constituído por instrumentos tributários denominados "contribuições sociais"20. Ao contrário dos impostos, as contribuições são exclusivas da União e não são repartidas com estados e municípios. Algumas contribuições antigas se enquadraram neste sistema, como o PIS/Pasep ${ }^{21}$ e as tributações sobre a folha de salários pagas por empregados e empregadores. Paralelamente foi criada uma contribuição baseada no faturamento das empresas, a Contribuição para o Financiamento da Seguridade Social (COFINS), e a previsão de uma contribuição sobre o lucro das empresas (que mais tarde deu origem à Contribuição Social sobre o Lucro Líquido, CSLL).

\footnotetext{
${ }^{18}$ Durante a tramitação da PEC 41/2003 alguns deputados nomearam esta alteração de "emenda Serra", em referência ao ex-deputado e então Senador por São Paulo, José Serra.

${ }^{19}$ Apesar de constar na Constituição, este imposto nunca foi criado, pois nunca se implementou a lei complementar que regularia o funcionamento do imposto.

${ }^{20}$ Apesar de o direito tributário brasileiro consagrar a diferenciação entre "impostos" e "contribuições", as assim chamadas "contribuições sociais" têm as duas características típicas de um tributo: elas são compulsórias e não vinculadas a um serviço para o pagador. Por isto, tecnicamente, a contribuição social é um tributo com um fim vinculado.

${ }^{21}$ O PIS, Programa de Integração Social, e o PASEP, Programa de Formação do Patrimônio do Servidor Público, foram criados em 1970, junto com o Programa de Integração Nacional. O objetivo do PIN era financiar a distribuição de terras e o apoio à agropecuária das regiões Norte e Nordeste. Secundariamente, ele foi uma compensação ao fim dos incentivos ao setor privado baseados no IRPJ no Nordeste. Ele marca a volta da tributação cumulativa no país depois de 1965 . Durante a crise fiscal dos anos 80 , os governos João Figueiredo e José Sarney aumentaram fortemente as alíquotas do PIS/PASEP, a fim de tentar equilibrar o orçamento.
} 
A história da COFINS é bem ilustrativa do espírito descentralizado e pouco coordenado da constituinte. Ela foi desenhada por duas comissões separadas. Em cada uma destas comissões ela tinha um objetivo diferente (Varsano, 1996). Na Comissão do Sistema Tributário, Orçamento e Finanças da Assembléia Nacional Constituinte foi estabelecido que um imposto federal, o FINSOCIAL ${ }^{22}$, seria usado para financiar um fundo temporário que coordenaria o processo de descentralização. Esse fundo daria recursos adicionais aos entes subnacionais para que estes tivessem condições de assumir os encargos antes exercidos pela União. Após um prazo de transição, o fundo se extinguiria, pressupondo que o aumento de arrecadação dos estados e dos municípios permitiria que eles exercessem suas atividades com arrecadação própria.

Já a Comissão de Ordem Social criou a previsão de uma contribuição permanente sobre o faturamento das empresas com características bem próximas do FINSOCIAL. A Comissão de Sistematização decidiu unificar as propostas e criar a CONFIS. Assim se eliminou a proposta de se criar um sistema organizado de descentralização dos encargos federais elaborada na Comissão de Finanças e se criou um tributo cumulativo de péssima qualidade.

Podemos dizer que do ponto de vista econômico a reforma de 1988 piorou a qualidade dos tributos e do federalismo fiscal. Foram criadas uma série de tributos em cascata através das contribuições sociais. Houve uma descentralização brusca da receita sem uma descentralização compatível dos encargos. O processo de transição elaborado pela Comissão de Tributação, Orçamento e Finanças se perdeu no processo constituinte, gerando uma descentralização desordenada. Contraditoriamente, esse processo tumultuado resultou em uma descentralização menor e mais lenta do que os constituintes desejavam, pois os governos subnacionais se recusaram a assumir determinados encargos, mesmo quando o governo nacional já não estava mais oferecendo estes serviços. A constituinte trabalhou em um contexto de déficit fiscal prolongado, e ainda criou novos direitos sociais, mas a reformulação tributária não foi suficiente para elevar os impostos a um nível condizente com as necessidades do orçamento. Como resultado, a descentralização contribuiu para agravar esta situação, pois o aumento dos recursos dos estados e municípios provocou quase de imediato uma elevação em seus gastos, aumentando o déficit público. Uma vez que a União permaneceu com muitas competências, gerou-se uma demanda por aumento de receita

\footnotetext{
${ }^{22}$ O FINSOCIAL foi criado durante a grave crise de 1982 para diminuir o déficit fiscal da União.
} 
no governo central. Durante os dez anos seguintes a União teve que lutar para conseguir recursos suficientes para reequilibrar seu orçamento e o orçamento dos demais níveis de governo. Afinal, em pouco tempo o déficit voltou aos orçamentos estaduais e municipais. $\mathrm{O}$ custo desse equilíbrio foi o aumento da carga tributária.

\subsection{4 - Principais modificações de 1988 a 2008}

A reforma de 1988 produziu uma descentralização assimétrica das competências públicas, pois os recursos foram descentralizados, mas as atribuições não foram da mesma forma. Este processo tendeu a provocar déficits na União.

Para enfrentar este déficit, a União teve que aumentar os tributos federais. A principal estratégia adotada pelos governos federais foi o aumento das contribuições sociais. Ao contrário dos impostos, as contribuições não precisam ser repartidas com os estados e municípios. Porém, esses tributos geram péssima eficiência alocativa, pois são cumulativos. Ironicamente, eles também atrapalham a diminuição das desigualdades sociais, contrariando o ideal social-democrata que norteou a Constituição de 1988. Como eles são tributos indiretos (tributos sobre produtos), incidem mais fortemente sobre as classes sociais que consomem uma parcela maior de sua renda, justamente o estrato mais pobre da população. O peso dos tributos indiretos é a principal explicação para a grande regressividade da carga tributária brasileira (Viana et alli, 2000, Hoffman, Silveira e Payeras, 2006, Zockun, 2007, e Payeiras e Hoffman, 2009).

Durante o período de 1990 até 2002, o governo Federal aumentou fortemente as alíquotas do PIS/PASEP, do IOF e da COFINS. Criou a CSLL e a CIDE (que não existiam antes). Criou, por emenda constitucional, a Contribuição Provisória sobre Movimentação Financeira (CPMF), que incidia sobre operações bancárias. Paralelamente a isso, houve um forte investimento em administração tributária, destinado a recompor a máquina arrecadatória, que havia se sucateado durante os anos 80. Como resultado, a carga tributária aumentou fortemente no período. Ela era de $24 \%$ do PIB em 1994 e passou a 37,37\% do PIB em 2005 (Varsano ett alli , 1998), (Receita

Federal, 2006). Apesar de todos os instrumentos tributários terem aumentado a arrecadação no período, as contribuições sociais foram as que mais cresceram. Para se 
ter uma ideia, a arrecadação do PIS/PASEP e da COFINS, saltaram de 1,17\% do PIB em 1988 (Varsano et alli, 1998, pg. 42) para 5,59\% em 2005 (Receita Federal, 2005). As receitas dos estados e municípios quase não aumentaram em proporção do PIB durante o período, estando quase todo o aumento concentrado na União.

Os estados e os municípios, assim, apesar de terem ficado com seus cofres cheios logo depois da Constituição de 1988, não tardaram a voltar a ter problemas orçamentários. Em 1996 a situação deles já era gravíssima. Segundo Varsano (1996, pg. 16-18), os principais motivos para isto foram: (a) a prolongada crise econômica que o país vivia desde os anos 80 , (b) o aumento do gasto com o funcionalismo público ${ }^{23}$, (c) a ampliação dos direitos sociais provocada pela nova Constituição; (d) no caso específico dos estados houve vigoroso aumento da guerra fiscal durante os anos 90, (e) no caso dos municípios, o aumento das transferências privilegiou os municípios pequenos, fazendo com que os municípios de médio e grande porte (os que mais cresceram em população no período) não fossem os mais beneficiados com as verbas adicionais. A frágil situação fiscal dos entes subnacionais, particularmente dos estados, favoreceu o governo federal na renegociação das dívidas subnacionais durante a segunda metade dos anos 90, resultado na criação da Lei de Responsabilidade Fiscal em 2000.

Entretanto, a mudança mais importante no que diz respeito aos tributos estaduais durante o período 1988-2008 foi a Lei Kandir (LC 87/1996). Ela regulamentou o funcionamento do ICMS. Seus efeitos mais importantes foram desonerar completamente as exportações (não apenas os produtos industrializados, que já estavam desonerados desde 1967) e desonerar parcialmente o ativo fixo das empresas. Para compensar os estados exportadores de bens primários, foi criado então um fundo de compensação composto de recursos orçamentários. O fundo era para ser temporário, mas o Congresso o renovou sucessivas vezes. Com o tempo, a distribuição do fundo deixou de ter relação com as exportações e passou a ser decidida de acordo com critérios políticos. O fundo se transformou em uma nova forma de transferências intergovernamental.

\footnotetext{
${ }^{23}$ Em grande parte este aumento foi resultado da pressão dos funcionários públicos por aumentos salariais. Desde o começo dos anos 90, o sindicalismo do setor público tem despontado como o mais forte e organizado do país. Mas, além disso, a Constituição de 88 aumentou os direitos do funcionalismo, seja efetivando funcionários temporário ou precários, seja estendendo direitos aos funcionários contratados pela CLT que antes só eram concedidos aos funcionários estatutários. Adicionalmente a isso, houve decisões judiciais no âmbito do STF que ampliaram os direitos dos funcionários públicos, ampliando direitos previdenciários, por exemplo.
} 
Os representantes dos estados, no entanto, resistem a encerrá-lo, pois (a) ele representa uma importante fonte de recursos para os estados mais pobres e (b) como o comércio interno é descontado parcialmente na origem e o comércio externo, totalmente no destino, os estados exportadores têm que pagar créditos de insumos gerados em outros estados. Vale dizer ainda: além de o estado exportador ter que abrir mão da sua receita na exportação, ele tem também que pagar créditos para as empresas exportadoras, devido à compra de insumos em outros estados. Muitos estados simplesmente não pagam estes créditos $^{24}$ gerando dívidas com os exportadores e criando um enorme passivo judicial.

Quanto à desoneração do ativo fixo, a Lei Kandir instituiu um mecanismo parecido com o sistema de créditos do ICMS. As empresas podem descontar os impostos pagos na compra de máquinas e equipamentos no imposto devido na venda de seus produtos. Isto foi uma forma de diluir o ônus concentrado que o Estado de São Paulo teria com a desoneração dos bens de capital, uma vez que esse estado sedia grande parte das empresas produtoras de máquinas industriais. O prazo mínimo para o aproveitamento destes créditos ficou em 48 meses, diminuindo grande parte do ganho de eficiência econômica que a medida objetivava.

Por fim, houve uma importante mudança na tributação indireta do Brasil com a criação das leis 10.637/2002, 10.8333/2003 e 10.865/2004. As duas primeiras tornaram o PIS/PASEP e a COFINS não cumulativas. Ou seja, deixaram espaço para as empresas descontarem de seus tributos o imposto pago nas etapas anteriores de produção. A última lei instituiu a cobrança do PIS /PASEP e da COFINS sobre os importados, gerando isonomia entre os produtos nacionais e os estrangeiros.

Como será argumentado mais adiante, o sucesso dessas duas importantes iniciativas, que melhoraram consideravelmente a qualidade do sistema tributário, devem-se ao fato de elas terem sido frutos de reformas incrementais, e não em uma grande reforma.

\footnotetext{
${ }^{24}$ Como dito no anexo II, quando o crédito é maior que o débito, o estado tem que devolver o crédito em dinheiro para a empresa, ou então permitir a comercialização dos créditos. Caso contrário, o ICMS se transforma em um tributo cumulativo.
} 


\section{2 - A Questão Tributária no Brasil atual: um resumo}

O sistema tributário brasileiro tem os seguintes impostos diretos: IRPF, IRPJ, CSLL, IOF, CPMF ${ }^{25}$, “Taxas", IPTU, ITR, IPVA, ITCD, IBTI, SIMPLES, ISS e contribuições sobre folha de salários ${ }^{26}$. Eles totalizam $59 \%$ da arrecadação do setor público em 2004 (Receita Federal, 2005). Os tributos indiretos são: IPI, PIS/PASEP, COFINS, CIDE, Imposto de Importação (II), Imposto de Exportação (IE) e ICMS; totalizando 41\% da arrecadação de 2004 (Receita Federal, 2005).

\begin{tabular}{|c|c|}
\hline \multicolumn{2}{|c|}{ Tabela III } \\
Impostos brasileiros de acordo com a base tributária \\
Base Econômica: & Impostos \\
\hline Imposto sobre a renda pessoal & IRPF \\
\hline Impostos sobre o lucro: & IRPJ e CSLL \\
\hline Impostos sobre a folha de salários: & $\begin{array}{c}\text { Contribuições Previdenciárias, Seguro de acidentes de } \\
\text { trabalho, Sistema "S", Salário Educação e "outros". }\end{array}$ \\
\hline Impostos sobre o faturamento: & IRPJ e CSLL (lucro presumido), SIMPLES e ISS \\
\hline Impostos sobre a venda e circulação de \\
produtos: & IPI, PIS/PASEP, COFINS ${ }^{27}$, CIDE e ICMS. \\
\hline Impostos sobre a propriedade: & IPTU, ITR, IPVA, ITCD, IBTI \\
\hline Impostos sobre as transações financeiras: & IOF e CPMF \\
\hline Impostos sobre o comércio exterior & II e IE \\
\hline Variável & "Taxas" federais, estaduais e municipais. \\
\hline
\end{tabular}

O sistema é caracterizando por ter muitos de impostos sobre a mesma base econômica, conforme mostra a tabela IV. Esta redundância aumenta sua complexidade, pois cada imposto tem um corpo legal distinto e uma operacionalização própria. O

\footnotetext{
${ }^{25}$ Extinta em 31/12/2007

${ }^{26}$ Estas contribuições englobam as Contribuições Previdenciárias, Seguro de Acidentes de Trabalho, Sistema "S", Salário Educação e "outros". O FGTS não foi incluído, por ser considerado uma poupança compulsória, não um imposto. As contribuições previdenciárias não foram tratadas com profundidade por questão de parcimônia. Tanto sua história quanto seus problemas são muito complexos e não são fundamentais para a argumentação mais à frente.

${ }^{27}$ O PIS/PASEP e a COFINS eram tributados sobre o faturamento até 2004. Ou seja, eram tributos em cascata muito piores para a atividade econômica.
} 
sistema tributário brasileiro - um conjunto de tributos criados em épocas diferentes, com intenções diferentes e com resultados práticos distintos -, segue, portanto, a lógica do palimpsesto.

Entre outros efeitos, essa complexidade aumenta o custo de transação do recolhimento dos impostos. Segundo o grupo de estudos Doing Bussiness, do Banco Mundial, uma empresa típica brasileira gasta 2600 horas por anos com o preenchimento de formulários e livros contábeis, sendo o país com o maior custo burocrático-tributário do mundo (Banco Mundial, 2009) ${ }^{28}$. Bertolucci e Nascimento (2002) calcularam que o desperdício de recursos derivado dessa burocracia seria por volta de $\mathrm{R} \$ 7,2$ bilhões ao ano (valores de 1999).

Além do custo burocrático, as alíquotas da tributação sobre os produtos são altíssimas. Ainda mais quando se considera que ela segue a lógica da tributação "por dentro" - ou seja, os tributos entram na base de cálculo dos impostos. A tabela a seguir, extraída de Zockun (2007, pg 7), ilustra a tributação típica de um produto brasileiro. A alíquota "por fora" já é altíssima, 41,25\%, mas quando se soma a isso o efeito cascata da tributação "por dentro", ela chega a incríveis $56,2 \%$.

\section{Tabela IV}

\begin{tabular}{|l|c|c|c|}
\hline & $\begin{array}{c}\text { alíquota nominal } \\
\%\end{array}$ & R\$ & $\begin{array}{c}\text { alíquota efetiva } \\
\%\end{array}$ \\
\hline custo sem impostos & 15,0 & 100,00 & \\
IPI & 17,0 & 17,65 & 17,7 \\
ICMS & 9,25 & 24,10 & 24,1 \\
PIS COFINS & 41,25 & 14,45 & 14,4 \\
soma & & 156,20 & 56,2 \\
\hline
\end{tabular}

Fonte: Zockun (2007), pg. 7.

Como resultado, os brasileiros típicos pagam uma altíssima carga tributária invisível sobre seus produtos típicos. Um estudo feito pelo Instituto Brasileiro de Planejamento Tributário (IBPT) sobre quarenta e oito produtos mostrou que apenas quatro tinham carga tributária menor que $23 \%$ (carne bovina e de frango, feijão e tijolo).

\footnotetext{
${ }^{28}$ O Grupo Doing Bussiness produz um relatório por ano. Nos últimos cinco anos, 2005-2010, o Brasil está estacionário em 2600 horas. Mais detalhes em http://www.doingbusiness.org/ .
} 


\section{Tabela V}

Conteúdo de tributos nos preços praticados no Varejo (válidos para o Estado de São Paulo)

\begin{tabular}{|c|c|c|c|c|c|}
\hline produtos & $\begin{array}{c}\text { preço em RS } \\
\mathrm{a} \\
\end{array}$ & $\begin{array}{c}\text { tributos / } \\
\text { preço final }\end{array}$ & $\begin{array}{c}\text { tributos } \\
\text { em RS } \\
b\end{array}$ & $\begin{array}{c}\text { preço sem } \\
\text { tributos em } \\
\mathrm{a}-\mathrm{b}\end{array}$ & $\begin{array}{c}\text { acréscimo de } \\
\text { custo tributário } \\
\mathrm{b} /(\mathrm{a}-\mathrm{b})\end{array}$ \\
\hline \multicolumn{6}{|l|}{ Materiais de Limpeza } \\
\hline detergente & 0,83 & $40,5 \%$ & 0,34 & 0,49 & $68 \%$ \\
\hline sabão em pó & 3,98 & $42,3 \%$ & 1,68 & 2,30 & $73 \%$ \\
\hline amaciante & 1,88 & $43,2 \%$ & 0,81 & 1,07 & $76 \%$ \\
\hline água sanitária & 1,42 & $37,8 \%$ & 0,54 & 0,88 & $61 \%$ \\
\hline desinfetante & 2,26 & $37,8 \%$ & 0,86 & 1,40 & $61 \%$ \\
\hline álcool & 2,99 & $43,3 \%$ & 1,29 & 1,70 & $76 \%$ \\
\hline sabão em barra & 3,31 & $40,5 \%$ & 1,34 & 1,97 & $68 \%$ \\
\hline saponáceo & 2,09 & $40,5 \%$ & 0,85 & 1,24 & $68 \%$ \\
\hline \multicolumn{6}{|c|}{ Materiais de Construção } \\
\hline vaso sanitário & 60,00 & $39,5 \%$ & 23,70 & 36,30 & $65 \%$ \\
\hline saco de cimento & 22,00 & $39,5 \%$ & 8,69 & 13,31 & $65 \%$ \\
\hline lata de tinta & 90,00 & $39,5 \%$ & 35,55 & 54,45 & $65 \%$ \\
\hline tijolo & 170,00 & $12,7 \%$ & 21,58 & 148,42 & $15 \%$ \\
\hline \multicolumn{6}{|c|}{ Bens de Consumo Durável } \\
\hline TV 29 polegadas & $1.249,00$ & $38,0 \%$ & 474,62 & 774,38 & $61 \%$ \\
\hline DVD & 620,00 & $38,0 \%$ & 235,60 & 384,40 & $61 \%$ \\
\hline som-Micro System & 890,00 & $38,0 \%$ & 338,20 & 551,80 & $61 \%$ \\
\hline automóvel & $28.000,00$ & $29,0 \%$ & $8.120,00$ & $19.880,00$ & $41 \%$ \\
\hline \multicolumn{6}{|l|}{ Mercearia } \\
\hline biscoito & 1,20 & $35,0 \%$ & 0,42 & 0,78 & $54 \%$ \\
\hline feijão & 3,34 & $18,0 \%$ & 0,60 & 2,74 & $22 \%$ \\
\hline açúcar & 1,01 & $40,5 \%$ & 0,41 & 0,60 & $68 \%$ \\
\hline sal & 0,74 & $29,5 \%$ & 0,22 & 0,52 & $42 \%$ \\
\hline farinha de trigo & 1,59 & $34,5 \%$ & 0,55 & 1,04 & $53 \%$ \\
\hline macarrão espaguete & 1,69 & $35,2 \%$ & 0,59 & 1,10 & $54 \%$ \\
\hline óleo & 3,82 & $37,2 \%$ & 1,42 & 2,40 & $59 \%$ \\
\hline café & 4,12 & $36,5 \%$ & 1,50 & 2,62 & $58 \%$ \\
\hline margarina $500 \mathrm{~g}$. & 3,52 & $37,2 \%$ & 1,31 & 2,21 & $59 \%$ \\
\hline sabonete & 0,90 & $42,0 \%$ & 0,38 & 0,52 & $72 \%$ \\
\hline iogurte & 3,67 & $24,0 \%$ & 0,88 & 2,79 & $32 \%$ \\
\hline suco de frutas & 3,02 & $37,8 \%$ & 1,14 & 1,88 & $61 \%$ \\
\hline leite longa vida & 1,53 & $33,6 \%$ & 0,51 & 1,02 & $51 \%$ \\
\hline achocolatado & 3,59 & $37,8 \%$ & 1,36 & 2,23 & $61 \%$ \\
\hline \multicolumn{6}{|l|}{ Enlatados } \\
\hline ervilha & 1,19 & $35,9 \%$ & 0,43 & 0,76 & $56 \%$ \\
\hline molho de tomate & 1,30 & $36,7 \%$ & 0,48 & 0,82 & $58 \%$ \\
\hline milho verde & 1,33 & $37,4 \%$ & 0,50 & 0,83 & $60 \%$ \\
\hline \multicolumn{6}{|l|}{ Carnes } \\
\hline bovina & 6,00 & $18,7 \%$ & 1,12 & 4,88 & $23 \%$ \\
\hline frango & 4,00 & $18,0 \%$ & 0,72 & 3,28 & $22 \%$ \\
\hline \multicolumn{6}{|l|}{ Bebidas } \\
\hline refresco em pó & 0,80 & $38,3 \%$ & 0,31 & 0,49 & $62 \%$ \\
\hline cerveja & 0,96 & $56,0 \%$ & 0,54 & 0,42 & $127 \%$ \\
\hline refrigerante em lata & 0,93 & $47,0 \%$ & 0,44 & 0,49 & $89 \%$ \\
\hline água 1,5 litro & 1,20 & $45,1 \%$ & 0,54 & 0,66 & $82 \%$ \\
\hline cachaça 1 litro & 3,10 & $83,1 \%$ & 2,58 & 0,52 & $491 \%$ \\
\hline \multicolumn{6}{|l|}{ Cama, Mesa e Banho } \\
\hline lençol & 26,80 & $37,5 \%$ & 10,05 & 16,75 & $60 \%$ \\
\hline toalha de banho & 16,80 & $36,3 \%$ & 6,10 & 10,70 & $57 \%$ \\
\hline cobertor & 34,90 & $37,4 \%$ & 13,06 & 21,84 & $60 \%$ \\
\hline \multicolumn{6}{|c|}{ Servicos de Utilidade Pública } \\
\hline energia elétrica & 100,00 & $45,8 \%$ & 45,80 & 54,20 & $85 \%$ \\
\hline telefone & 100,00 & $40,5 \%$ & 40,50 & 59,50 & $68 \%$ \\
\hline \multicolumn{6}{|l|}{ Outros } \\
\hline gasolina & 1,99 & $57,1 \%$ & 1,14 & 0,85 & $133 \%$ \\
\hline remédios & 100,00 & $30,4 \%$ & 30,38 & 69,62 & $44 \%$ \\
\hline cigarro & 2,50 & $81,7 \%$ & 2,04 & 0,46 & $446 \%$ \\
\hline
\end{tabular}

Fonte: IBTP - Instituto Brasileiro de Planejamento Tributário, apud ACSP - Associação Comercial de São Paulo ("Feirão de Impostos"). 
Em outros quatro, a variação era entre 23 e $50 \%$, em outros vinte e nove era entre $50 \%$ e $70 \%$, e finalmente, nos restantes onze, era de mais de $70 \%$.

Essa carga tributária indireta não tem paralelos no mundo. Para se ter uma ideia, a alíquota máxima sobre o valor agregado é de 17,5\% no Reino Unido, 19,5\% na França e $27 \%$ na Argentina. Já no Brasil, a alíquota pode chegar a 135\% (sem contar produtos nocivos à saúde, como cigarros e bebidas alcoólicas). Como resultado, o Brasil tem um sistema tributário extremamente regressivo.

Utilizando-se dos dados da Pesquisa de Orçamentos Familiares (POF) do IBGE 1995-96, Vianna et al (2000) já haviam mostrado que a carga tributária direta no Brasil era progressiva ${ }^{29}$, mas a carga tributária total era regressiva, devido à forte regressividade dos impostos indiretos. Corroborando tal resultado, o estudo do IPEA assinado por Hoffman, Silveira e Payeras (2006, pg. 13), com a mesma base de dados, mostrou que o sistema brasileiro é regressivo até o $95^{\circ}$ percentil da renda, sendo levemente progressivo apenas para os $5 \%$ mais ricos.

A situação parece que não se alterou muito durante a segunda metade da década de 90. Zockun (2007, pg. 19), com dados da POF de 2002-2003, chegou aos seguintes resultados:

\section{Gráfico 1 - Carga tributária total sobre a renda das famílias (em \% da renda mensal familiar)}

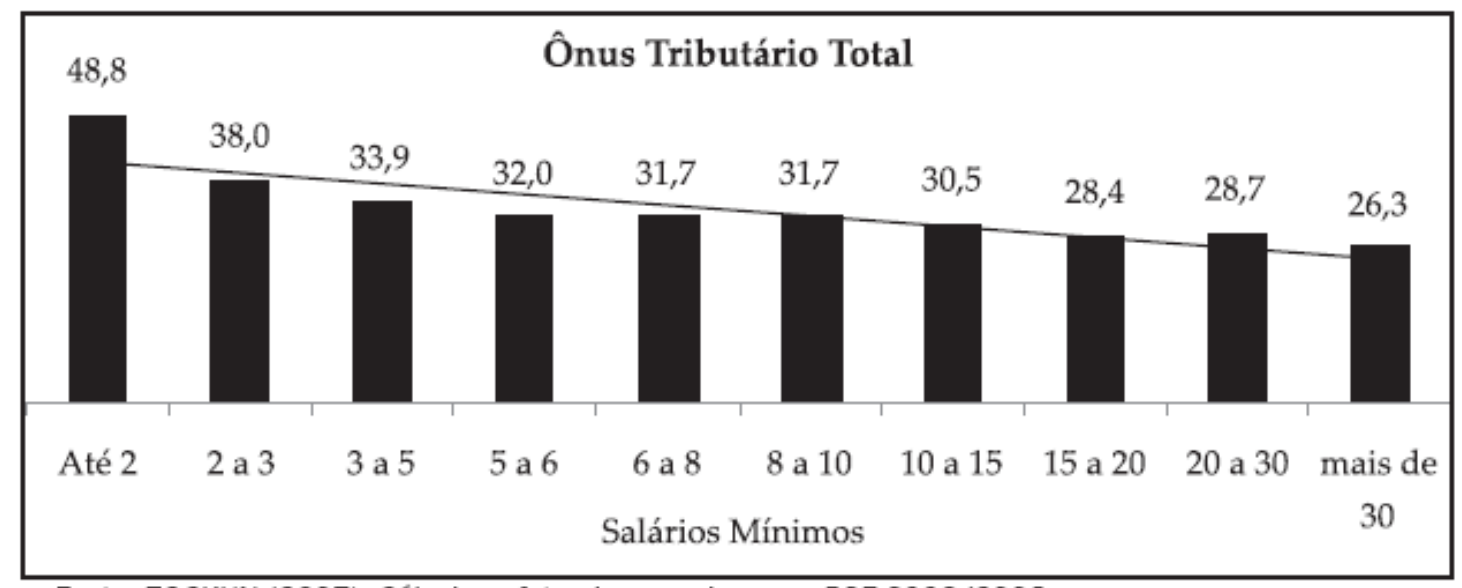

Fonte: ZOCKUN (2007). Cá́lculos efetuados com base na POF 2002/2003.

\footnotetext{
${ }^{29}$ Embora o autor chame a atenção para a desigualdade dentro da tributação direta. Enquanto os empregados pagam $9,78 \%$ de seus rendimentos com impostos diretos, os ganhadores de aluguéis e aplicações de capital ganham $3,36 \%$ e $2,15 \%$, respectivamente.
} 


\section{Gráfico 2 - Carga tributária direto sobre a renda das famílias}

(em \% da renda mensal familiar)

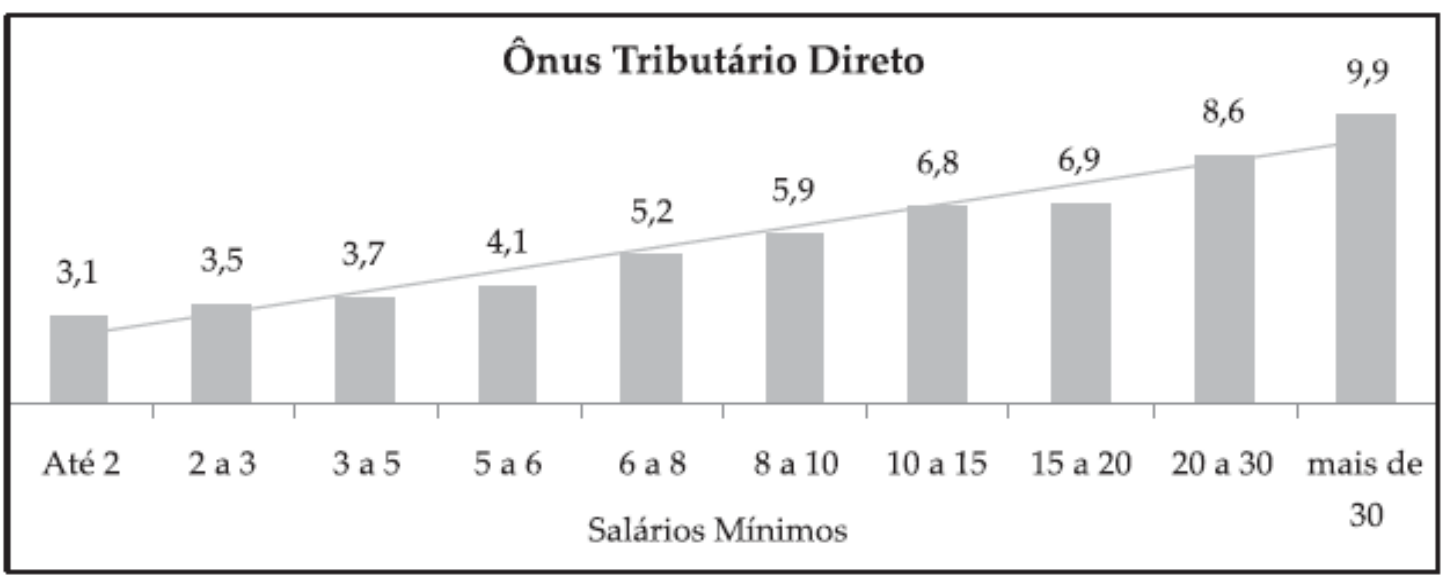

Fonte: Zockun (2007). Cálculos efetuados com base na POF 2002/2003.

Gráfico 3 - Carga tributária indireto sobre a renda das famílias (em \% da renda mensal familiar)

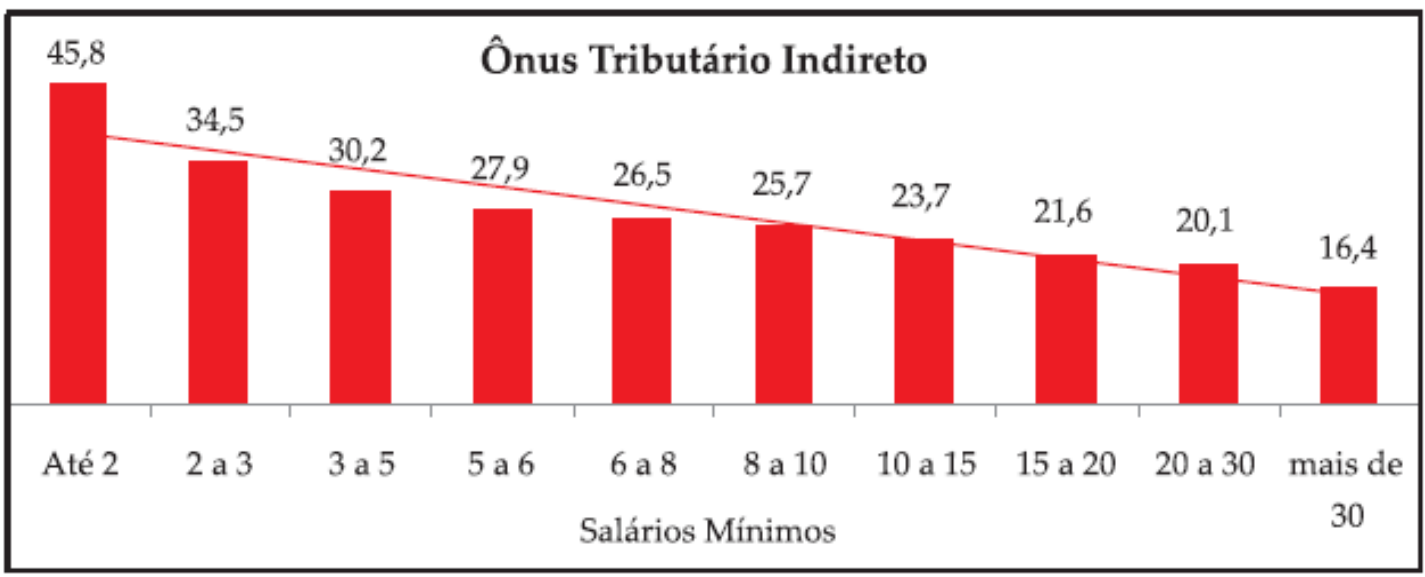

Fonte: Zockun (2007). Cálculos efetuados com base na POF 2002/2003.

(Gráficos Extraídos de CDES, 2009)

As famílias com renda total de até dois salários mínimos pagam em média o equivalente a $48,8 \%$ do seu rendimento em impostos. Já as famílias com renda maior que trinta salários mínimos pagam o equivalente a $26,3 \%$ dos seus rendimentos em 
impostos. Assim, podemos dizer seguramente que o sistema tributário contribui efetivamente para a gritante disparidade de renda do país.

Todavia, além dos seus efeitos deletérios sobre a desigualdade, o sistema tributário estimula a sonegação. Afinal, poucas empresas conseguem adicionar valor suficiente para entregar os valores acima mencionados ao fisco e ainda manter razoáveis taxas de lucro. Segundo Zockun (2007):

\begin{abstract}
Mas como os impostos são recolhidos pelas empresas, independentemente de terem sido cobrados do consumidor, as menos produtivas têm três alternativas: i) ou recolhem ao fisco a totalidade do tributo, retirando parte dos recursos do seu próprio capital, se descapitalizando e comprometendo sua sobrevivência a médio prazo; ii) ou ficam inadimplentes cronicamente, porque não geram valor adicionado para recolher a totalidade dos tributos correntes; iii) ou submergem na informalidade, apresentando apenas uma fração de suas operações ao fisco. (pg. 12)
\end{abstract}

\title{
1.2.1 - Problemas do ICMS: um resumo
}

O ICMS é o maior e mais problemático tributo brasileiro. Ele é fortemente regressivo e provoca distorções na atividade econômica - e mesmo na atividade política. Tais problemas derivam da autonomia estadual sobre a regulamentação do imposto, que desencadeou uma trajetória desorganizada e competitiva do tributo, e das próprias regras nacionais, segundo as quais as alíquotas interestaduais são menores que as internas.

Como o ICMS é o principal alvo das reformas tributárias pretendidas nos governos Fernando Henrique Cardoso e Luis Inácio Lula da Silva, seus problemas serão estudados em mais detalhes nesta seção.

\subsubsection{1 - Tributação na origem e dupla autoridade tributária}

O ICMS é tributado em grande parte na origem, conforme mostra o anexo II. A tributação na origem é mais fácil de ser fiscalizada do que a tributação no destino, pois a 
produção é mais concentrada do que as vendas a varejo. Como consequência, a porcentagem da tributação na origem é bem maior do que a mera análise das alíquotas faz supor, pois a sonegação no Brasil não é desprezível.

A teoria econômica do federalismo fiscal (Cossio, 2000) vê negativamente a tributação na origem em governos subnacionais, pois ela gera uma "assimetria de informação" entre o governo e os cidadãos. Quando os recursos arrecadados localmente são gastos em benefícios locais, a comunidade tem a correta percepção da relação custo/benefício dos serviços públicos, podendo determinar a quantidade de bens públicos que maximiza seu bem-estar. Desse modo, os tributos mais apropriados para as administrações locais são as tributações sobre propriedades imóveis, pois esse fator econômico tem mobilidade jurisdicional zero e não pode gerar distorções na percepção custo/benefício. Nesses tributos, a correspondência entre contribuintes e beneficiários é clara, uma vez que a provisão de serviços públicos locais tende a provocar a valorização das propriedades dentro de uma jurisdição. Inversamente, caso o financiamento dos níveis locais de governo seja feito com tributos retirados de fatores móveis, três consequências danosas poderão acontecer (Cossio, 2000):

(1) Os governos locais poderão transferir os custos de seu financiamento para toda a coletividade. Por exemplo: se uma fábrica sediada em determinado município tiver sua produção taxada por aquele município, ela transferirá o custo tributário para os preços dos produtos - que fatalmente não serão consumidos apenas por aquele município. Ou seja, é como se o município pudesse taxar os contribuintes de fora de seu território, gerando a chamada "exportação de impostos".

Esse tipo de distorção gera uma ineficiência decorrente da "assimetria de informação", pois os cidadãos perderão a capacidade de avaliar quanto custa seu governo local. Como quem financia os serviços públicos são os consumidores de fora da jurisdição, os cidadãos locais passarão então a acreditar que os bens públicos custam menos do que realmente custam. Como consequência, eles passarão a demandar uma quantidade excessiva de bens públicos. Paralelamente, os governos perceberão que criar estruturas administrativas ou mesmo adotar práticas de corrupção ou rent-seeking não produz um ônus político grande, pois não são seus eleitores que arcam com o custo dessas medidas, mas toda a economia nacional.

(2) Os governos locais também podem sofrer por taxações de governos externos, provocando uma assimetria de informação de características inversas do caso anterior, 
sobrevalorizando os custos das atividades estatais. Nesses casos, as comunidades locais tendem a demandar excessivamente cortes de impostos, diminuições de benefícios, ou, como ocorre no Brasil, não prover as demandas sociais de forma apropriada.

(3) As diferentes comunidades podem usar os sistemas tributários para atrair investimentos produtivos, a chamada "guerra fiscal".

O Brasil permite, de vários modos, todas essas distorções em seu sistema tributário.

Um caso claro é o ICMS. Como mostrado na tabela II, as prefeituras têm o direito de receber $25 \%$ da arrecadação do imposto gerado em suas jurisdições. Os pequenos municípios com grandes indústrias, como Paulínia (SP) e Cubatão (SP), tendem a ter uma altíssima arrecadação per capita (em 2002 foi $\mathrm{R} \$ 5.420,73$ e $\mathrm{R} \$ 1.369,43$, respectivamente), enquanto as cidades-dormitório - como Francisco Morato (SP) e São Vicente (SP) - tendem a ter uma baixíssima arrecadação (R \$ 42,69 e $\mathrm{R} \$ 66,75$ per capita, respectivamente). As cidades-dormitórios tendem a acumular problemas sociais e deficiências nos serviços públicos. Já o setor público das cidades com alta arrecadação tende a apresentar crônico comportamento rent-seeking. Em Alvorada (RS), cidade de 22 mil habitantes e arrecadação per capita de R\$2.136,79, o ex-prefeito, Bento Gonçalves dos Santos (PPB), já chegou a empregar $10 \%$ da população para se perpetuar no poder, mas foi condenado na Justiça e preso ${ }^{30}$.

Os estados também praticam a "exportação de impostos" com o ICMS. Afinal, o presente sistema tributário tende a beneficiar os estados com balança comercial interestadual (BCI) favorável, os exportadores líquidos da federação, sobretudo São Paulo. Como todos os estados consomem produtos produzidos por São Paulo e, por isso, contribuem em ICMS com a arrecadação do estado. Com isto, gera-se uma grande distorção: o sistema de tributação brasileiro faz com que o estado mais rico da federação se sustente baseado da contribuição dos cidadãos dos estados mais pobres.

O princípio da origem e sua consequente exportação de impostos fazem, também, com que a tributação recaia sobre setores equivocados. A maioria dos países do mundo não tributa produtos que geram grande bem-estar social, como alimentos e remédios. Já no Brasil, os alimentos são tributados porque os estados agrícolas sabem que uma grande parte do imposto será pago por outros estados, fazendo com que o custo

30 "Governo quer critério social no rateio do ICMS", O Estado de São Paulo, 05/05/2003. 
da medida seja diluído por toda a economia nacional. Trata-se, assim, de uma estratégia que beneficia o estado que a pratica, mas prejudica o conjunto dos estados, configurando-se como um jogo de soma negativa.

Cabe ressaltar, ainda, que, segundo Vianna et alli (2000), a tributação dos estados mais pobres é mais regressiva do que a dos estados mais ricos, pois eles não podem abrir mão de taxação sobre os produtos básicos, da mesma forma que os estados mais ricos fazem. Dessa forma, os pobres dos estados mais pobres pagam mais impostos do que os pobres dos estados mais ricos. Os remédios apresentam um problema parecido. Eles são fortemente taxados, porque sua produção é concentrada no Estado de São Paulo. Esse estado resiste a desonerações nesse setor. Afinal ela permite que ele retire renda dos consumidores dos demais estados.

A autonomia estadual do ICMS também perverte a lógica da tributação sobre o consumo. Por definição, um tributo sobre o consumo não atinge investimentos ou exportações. Do ponto de vista econômico, é danoso para o país taxar os investimentos, pois isso tende a diminuir o aumento da capacidade produtiva no longo prazo. No mesmo sentido, a tributação das exportações (outra forma de exportação de impostos) diminui a competitividade do país no comércio internacional, fazendo com que os produtos brasileiros sejam mais caros do que seu custo de produção.

Legalmente, o ICMS não deveria ser cobrado nas exportações. Porém, os estados exportadores argumentam que essa medida os prejudica, pois eles devem não apenas abrir mão da tributação sobre os produtos exportados, mas também devolver às empresas os créditos adquiridos durante a compra dos insumos. Isso se deve ao fato de que o ICMS opera com o princípio misto no comércio interno e com o princípio do destino no comércio internacional. Assim o presente sistema tributário prejudica os estados que exportam muito, mas não tem uma grande importação, ou seja, os estados exportadores de produtos primários (Pará, Mato Grosso do Sul, Rondônia, etc).

A Lei Kandir foi particularmente danosa para esses estados, pois os estados industrializados conseguem repor parte da perda decorrente da desoneração das exportações com a oneração das importações. Já os estados exportadores de produtos primários não têm esta vantagem, pois seu mercado interno é pequeno.

Outro problema do ICMS é o fato de ele ser cobrado parcialmente na origem e parcialmente no destino, o que faz com que as empresas fiquem sob dupla autoridade tributária no comércio interestadual. Isto aumenta a complexidade do sistema. Empresas grandes e pequenas têm que obter assessoria tributária em vinte e 
sete legislações estaduais diferentes. Isso, lembrando que a normatização do imposto não envolve apenas as leis, decretos e portarias, mas também as decisões judiciais, a interpretação e a execução dos regulamentos. Daí por que o ICMS é o principal responsável pela empresa média brasileira gastar 2600 horas com a burocracia tributária (Banco Mundial, 2009). Cada máquina fiscal estadual funciona de uma forma e as empresas têm que estar preparadas para responder a exigências de todos os lados. Como se não bastasse a pluralidade das legislações, a guerra fiscal também aumenta a complexidade do sistema, impondo mais e mais regimentos. Afinal, os estados acabam criando um grande número de exceções e regimes especiais para atrair empresas.

Por outro lado, as empresas que não querem pagar seus impostos podem usar o sistema a seu favor, seja através do planejamento tributário (o uso de brechas na lei para pagar menos impostos), seja através da sonegação.

Nesse sentido, uma das fraudes mais comuns é a "operação interestadual simulada" ou "passeio das notas". A empresa registra sua venda como interestadual, mas as mercadorias nunca saem do estado. Apenas as notas fiscais transitam. Com isso a empresa paga apenas a alíquota interestadual, que é menor que a alíquota interna. Outra forma se dá através da triangulação tributária. Uma empresa abre um centro de distribuição em um estado onde ela tem um benefício fiscal e, e então, esse centro de distribuição vende para o consumidor final com um imposto reduzido ${ }^{31}$. Trata-se de uma operação vantajosa para a empresa, pois ela consegue vender seus produtos com um imposto menor. Ao mesmo tempo, o estado que concede o benefício consegue "roubar" uma parte do imposto que, de outra maneira, seria tributado pelo estado de destino.

As possibilidades de burlar o sistema são muitas e não é objetivo deste texto detalhar todas elas. Apenas se quer ressaltar que o sistema oferece enormes dificultadas para as empresas que querem ser honestas, mas facilita o trabalho dos que querem evitar ser alvo das regras gerais.

O sistema de alíquotas interestaduais menores do que as internas também causa algumas distorções no comércio interestadual e na localização espacial das empresas.

\footnotetext{
${ }^{31}$ Para que a empresa não perca seus créditos na etapa posterior de produção, o estado concede o seguinte benefício: a empresa não terá reduzidos seus impostos, mas uma parte deles será financiada por um longo prazo (a maioria dos estados concede uma carência de 20 a 25 anos), sem juros ou correção monetária. Estes créditos entram na dívida ativa do estado e podem ainda ser alvo de anistia no final do período. Assim, para todos os efeitos legais, a empresa beneficiária paga os impostos e deve receber os devidos créditos na próxima etapa de produção. Assim, o estado de destino da mercadoria tem que pagar créditos sobre impostos pagos "ficticiamente" no estado de origem.
} 
Segundo Baratto (2006), com a alíquota interestadual menor que a interna, o estado de destino suporta valor menor de crédito, consequentemente, então, ele receberá um valor maior de imposto (veja os números em negrito da tabela do anexo II). Se por um lado o sistema de alíquotas interestaduais menores do que as internas redistribui a arrecadação em favor do estado de destino, por outro lado, ele também possibilita que as compras realizadas de empresas de fora do estado sejam menos tributadas do que as compras realizadas dentro do estado, fazendo com que os produtos de fora sejam mais baratos que os internos. Isso cria uma verdadeira "barreira tributária às avessas", incentivando as empresas a comprar produtos de outros estados a produtos do próprio estado, aumentando os custos de transporte e logística. Além disso, as empresas do $\mathrm{N} / \mathrm{NE} / \mathrm{CO}+\mathrm{ES}$ acabam sendo estruturalmente mais tributadas, pois nessas regiões a alíquota interestadual é de 12\%, enquanto nas regiões S/SE+ES ela é de 7\%. Ou seja, as regras nacionais do ICMS prejudicam a competitividade das regiões mais pobres do país.

Varsano (1979, APUD Baratto, 2006) já ressaltava que o aumento da diferença entre as alíquotas internas e as interestaduais criava uma contradição entre o aumento da arrecadação das regiões pobres e a competitividade destas mesmas regiões. Segundo ele, os cofres dos governos estaduais do Nordeste seriam beneficiados, mas suas economias prejudicadas (Varsano 1979, APUD Baratto, 2006 p. XX).

Cabe ainda lembrar que a diferença entre as alíquotas internas e interestaduais também estimula a sonegação, pois incentiva os agentes econômicos a fazer vendas simuladas. Nesse sentido, Baratto (2006) ressaltou que:

Os agentes econômicos (contribuintes) também perceberam que poderiam "brincar" com as alíquotas, valendo-se do instrumento para fazer planejamento tributário, operação triangular, praticar preços de transferência e toda sorte de manipulações que um IVA não neutro permite, valendo-se das alíquotas diferenciadas [interestaduais] para ao fim e ao cabo suportarem uma carga tributária efetiva de ICMS mais baixa. (pg. 111)

Da mesma forma, as alíquotas interestaduais pequenas estimulam as empresas a não registrarem a entrada de mercadorias. Por mais que este procedimento implique no revés de eliminar a geração de crédito para as etapas seguintes de produção, ele permite, por outro lado, a não escrituração das saídas das mercadorias, resultando em mais sonegação. Isso, manifestadamente, acaba com uma das maiores vantagens do ICMS: o 
incentivo que as empresas do final da cadeia produtiva têm em comprar insumos de empresas que são formais.

\subsubsection{2 - Guerra Fiscal do ICMS}

Desde a volta da autonomia estadual em 1982, os estados usam seus sistemas tributários para atrair investimentos, uma estratégia que se acirrou a partir da segunda metade da década de 90. A maior parte da literatura econômica vê esse fenômeno negativamente (Varsando, 1997, Oliveira, 1999, Tyler, 1998, Prado e Cavalcanti, 2000, Arbix, 2001, Silva, 2001, Dulci, 2002, Biermann et alli, 2004, Prado, 2006, Nascimento, 2008), embora autores ligados à teoria da "escolha pública" e do "modelo Tiebout" defendam a competição intergovernamental (Tiebout, 1956, Gordon, 1983, Brennan e Buchanan, 1995).

Não é objetivo desse trabalho fazer uma revisão detalhada dessa polêmica. Mas como um dos objetivos declarados das três reformas estudadas era acabar com a guerra fiscal, nesta seção terá lugar uma revisão dos argumentos contra a disputa interestadual por investimentos ${ }^{32}$.

O ICMS se caracteriza como sendo um imposto não neutro. Ou seja, ele muda as preferências das famílias e empresas com relação às que elas teriam em um mercado totalmente livre. A guerra fiscal do ICMS acentua essa característica.

Quando uma empresa escolhe sua localização devido a benefícios fiscais e não por fatores decorrentes dos custos de produção - como proximidade com o mercado consumidor, proximidade com as matérias-primas, custo e qualidade da mão de obra, etc - ela está sofrendo uma distorção alocativa. Vale dizer, a empresa, incentivada a mudar seu lugar de estabelecimento por vantagens tributárias, perdeu eficiência produtiva para ganhar uma vantagem comercial. Nesse sentido, se a prática de benefícios fiscais for disseminada, também será disseminada a perda de produtividade. A empresa beneficiada pode ter seus lucros aumentados, mas o país terá perdas

\footnotetext{
32 É importante ressaltar que as análises empíricas sobre o caso brasileiro se posicionam quase unanimemente contra a guerra fiscal. Os autores que defendem a competição interestaduais são quase todos estrangeiros e teóricos. É bem possível que algum tipo de disputa intergovernamental por pessoas e capitais seja inevitável; ou mesmo desejável. Porém, as regras do ICMS no Brasil estimulam uma competição predatória, não uma concorrência saudável.
} 
econômicas decorrentes do aumento dos custos de transporte e logística, subutilização de mão de obra qualificada, etc ${ }^{33}$.

A guerra fiscal também gera perda de arrecadação para o setor público. Ela não é um jogo de soma zero, no qual uns perdem e outros ganham na mesma proporção. Como existe uma redução de tributos para as empresas, o conjunto da tributação é reduzido. Ora, isso, entretantanto, não quer dizer que todos os estados percam recursos. O sistema de tributação na origem faz com que o estado que entra na guerra fiscal conceda isenções que prejudicam os demais estados, não ele próprio. Segundo Prado (2006):

Por outro lado, é também inegável outra conclusão: a competição leva a resultados positivos, no médio e longo prazo, para aqueles estados que saem vitoriosos na disputa por investimentos. Ao atrair para seus estados uma parcela maior da atividade industrial, garantem, além dos benefícios imediatos em emprego e renda, uma ampliação futura da arrecadação de ICMS. Essa é a face complexa e paradoxal da "guerra fiscal": o país como um todo perde ao conceder benefícios em geral muito mais elevados para mudar a localização das plantas produtivas. Na maior parte dos casos, os projetos seriam realizados com ou sem incentivos, pois constituem parte do planejamento estratégico de expansão das empresas nos diversos mercados. Mas, por outro lado, os "vitoriosos" ganham. (pg. 12)

Diante desse quadro, são os estados industrializados, notadamente São Paulo, que perdem recursos, não os estados que recebem as empresas. Por mais que as isenções, financiamentos de impostos e reduções na base de cálculo sejam generosas, os estados pobres acham melhor serem produtores do que consumidores de mercadorias. Evidentemente as perdas dos estados industrializados são desproporcionais aos ganhos dos estados não industrializados, principalmente em termos de geração de postos de trabalho. Segundo Nascimento (2008), uma característica marcante da guerra fiscal é a baixa geração de empregos, apesar de muitos governadores defenderem os incentivos fiscais como forma de gerar postos de trabalho para seus estados. A guerra fiscal tende a diminuir a relação entre aumento do PIB e geração de empregos, pois as novas plantas apresentam elevada relação capital/trabalho.

\footnotetext{
${ }^{33}$ A isso se acrescenta o fato de que isenções para atrair empresas novas poderem resultar em aumento de impostos para as empresas domésticas, o que pode ocorrer devido a perda de arrecadação ou a aumento das demandas sociais geradas pela instalação da empresa - em transporte público, infraestrutura viária, habitação, etc. Nascimento (2008, pg. 683) diz que essa política é como o estado do Piauí isentar uma fábrica de fibra ótica e aumentar o ICMS dos produtores de óleo do Babaçu.
} 
Por todos esses motivos, a guerra fiscal é um perfeito exemplo de self-enforce policy. Quando um jogador a inicia a política, fica difícil para os demais deixarem de entrar nela. Com o tempo, aliás, todos entram na guerra, anulando grande parte de seus efeitos sobre a redistribuição do investimento nacional. Contudo, os estados não conseguem sair dela, pois a concessão de benefícios vira pressuposto para a instalação de grandes empresas em seu território. Ou seja, ao final, a guerra se transforma em uma pura transferência de renda para o setor privado.

Nesse sentido, segundo Tyler (1998), a política de incentivos fiscais gera mercados ineficientes. Como apenas empresas grandes conseguem obter incentivos fiscais, devido ao elevado custo em buscar e obter os mesmos a guerra fiscal tende a prejudicar as pequenas empresas, criando barreiras à entrada nos mercados. Isso facilita o surgimento de oligopólios e monopólios. Além disso, o esquema parece canalizar investimentos em atividades lobistas em detrimento dos investimentos em modernização das plantas.

Há também um efeito de insegurança jurídica decorrente disso. Os empresários não sabem se, ao instalar uma empresa, seus concorrentes receberão algum incentivo fiscal criando uma concorrência assimétrica. Este fator, por sua vez, é um desincentivo ao investimento, prejudicando o aumento da capacidade produtiva.

Por fim, mas não menos importante, a disputa federativa no comércio atacadista aumenta a "barreira tributária às avessas" do ICMS. As importações são taxadas pelo ICMS com vistas a produzir igualdade de condições entre o produto externo e o interno. Assim, as importações acabam funcionando pelo princípio da tributação no destino (obviamente, não faz sentido cobrar na origem as importações, pois elas são produzidas em outros países). Apesar de a LC 87/96 (Lei Kandir) determinar que o ICMS das importações deve pertencer ao destino físico das mercadorias, o que é determinante para efeitos de incidência do importo é o destino jurídico das mercadorias: a empresa importadora.

Aproveitando-se do fato de que as operações seguem dois princípios distintos nas transações internacionais, alguns estados passaram então a conceder isenções para atrair importadores. O primeiro estado a usar esta tática foi o Espírito Santo através da FUNDAP (Fundo de Desenvolvimento das Atividades Portuárias), mas ele foi seguido por quase todos os outros estados. O lado mais pernicioso de tal mecanismo é que ele é integralmente bancado pelo estado que é destinatário físico das importações, pois o estado importador taxa a mercadoria na sua chegada ao país (segundo o princípio do 
destino) e depois a revende, cobrando o imposto segundo o princípio da origem. A empresa importadora não tem grandes custos com esta operação, ao contrário, ganha créditos com o estado que é destino físico das mercadorias, que mais que compensa os impostos pagos.

Suponhamos o seguinte exemplo: um produto tem uma alíquota de $15 \%$. Então, um estado isenta completamente a importação deste produto. Os importadores se instalam naquele estado e passam a revender a mercadoria para outros estados pagando a alíquota interestadual de $12 \%$. O estado financia parcialmente esse imposto com uma carência de 25 anos (sem juros ou correção monetária), de modo a que a alíquota efetiva seja de 5\%. O importador físico da mercadoria, então, ganha o direito de abater $12 \%$ de imposto pago na etapa anterior do produto, suportando carga efetiva de $8 \%$ de ICMS. Nesse sistema, então, o estado importador "roubou" arrecadação do estado destino físico da mercadoria, pois tal imposto seria dele na ausência dos benefícios fiscais. $\mathrm{O}$ saldos das transações resulta, ao final, no seguinte: $3 \%$ do produto fica com o estado destino físico, $5 \%$ fica com o estado importador e $7 \%$ é apropriado pelo setor privado.

Sapienza et al. (1998, p. 41, APUD Nascimento, 2008, pg. 681) conta que:

Em 1994, o Brasil importou cerca de 300 mil automóveis, 90\% dos quais entraram pelo Porto de Vitória. Desses, 45\% foram destinados ao Estado de São Paulo. Na prática, criou-se um instrumento legal para arrecadar $30 \%$ do imposto gerado na operação, pois prorrogar por 25 anos uma receita, sem corrigi-la, é praticamente abrir mão dela ou, pelo menos, de boa parte dela, principalmente se houver elevados índices de inflação no período.

A instituição desse mecanismo criou uma corrida para a redução de ICMS das importações, criando uma "barreira alfandegárias às avessas" também no comércio exterior. Isso foi extremamente prejudicial à indústria nacional, pois os produtos importados tinham uma vantagem tributária com relação aos produtos nacionais. Caso houvesse o princípio do destino nas operações internas (ou a proibição de benefícios fiscais por parte dos estados), não haveria esse problema.

Como se pode ver, então, o sistema tributário carrega uma infinidade de problemas. Ele prejudica o investimento, a competitividade, cria distorções alocacionais das empresas e regiões, aumenta a desigualdade social e perverte o sistema político.

Porém, fica a questão: se o sistema é tão ruim, por que nenhuma das três tentativas de reforma foi bem sucedida? 


\section{2- A Ausência de uma Reforma Tributária no Brasil: teorias explicativas}

A literatura política sobre a reforma tributária no Brasil aponta três motivos para o fracasso das reformas: (1) a tendência à paralisia decisória do sistema político, (2) o poder de veto dos governos estaduais e (3) o desinteresse ou falta de consenso interno do Executivo.

As duas primeiras causas se referem à estrutura do sistema político. Na década de 80 e no início dos anos 90, os brasilianistas americanos e os cientistas políticos brasileiros mais respeitados (Ames, 2003) (Lamounier, 1996) (Mainwaring, 2001) viam o sistema político do país como excessivamente fragmentado, indisciplinado, desordenado, personalista, clientelista e ineficiente do ponto de vista econômico e democrático. O sistema político era visto como produtor de ingovernabilidade.

Os problemas políticos do país estariam nas regras eleitorais e no sistema presidencialista. As regras eleitorais brasileiras, baseadas no sistema de representação proporcional de lista aberta (RPLA), tenderiam a criar um número exagerado de partidos e desincentivar a coesão interna dos mesmos. Como o voto é normalmente direcionado a um parlamentar individual, os deputados dependem de sua reputação e recursos pessoais para se eleger. Por conseguinte, eles tenderiam a agir individualmente, não coletivamente. Esse mecanismo é chamado de "conexão eleitoral", pois diz que o comportamento legislativo do parlamentar é derivado das regras que regem as eleições. O sistema presidencialista seria problemático, então, porque o Executivo e o Congresso são eleitos de forma independente, gerando o risco de partidos opostos vencerem nos diferentes poderes. Como o sistema não é bipartidário (tal qual nos Estados Unidos), as chances do partido do presidente ter a maioria das cadeiras no Congresso são mínimas.

O sistema seria, além disso, clientelista, pois os parlamentares individualistas não têm incentivos para formular programas nacionais. Como eles dependem da própria reputação para se eleger, eles dedicar-se-iam a políticas localizadas, destinadas a formar uma base pessoal. Eleitoralmente, é muito melhor usar políticas de benefícios concentrados do que benefícios difusos, pois benefícios difusos são menos perceptíveis para o eleitorado. Também é melhor jogar a conta destas políticas para toda a população

(custos difusos), justamente porque assim os custos se tornam menos visíveis. O resultado são políticas clientelistas (pork barrel), onde todos pagam e poucos recebem. 
A tendência favoreceria, portanto, pressões contra a disciplina fiscal e uma política baseada na barganha de verbas, cargos, subsídios e privilégios localizados.

O sistema seria também descentralizado, pois sem a intermediação dos partidos, o Executivo tem que negociar com cada parlamentar individualmente. Isso ainda acarretaria um alto custo de transação, tornando tremendamente difícil implementar reformas estruturais, como a reforma tributária.

Ademais, teríamos um agravante: o sistema federativo. Segundo Fernando Abrúcio (1998), o sistema político brasileiro seria caracterizado como tendo uma estrutura localista, segundo à qual os parlamentares se preocupam mais com os interesses de sua base eleitoral do que com preocupações nacionais e partidárias. Além disso, os governadores também podem jogar o jogo do pork barrel com os deputados, fazendo com que a dinâmica política tenha contornos estaduais. Assim, o parlamento nacional seria uma espécie de "assembleia dos estados". Abrúcio (1998, pg. 178-179) afirma que "vinte e sete 'bancadas estaduais' são formadas com grande independência dos partidos políticos". Isso faz com que os governadores se tornem atores com poder de veto sobre o governo federal. As reformas que prejudicam os governadores (como a reforma tributária) encontrariam barreiras no Congresso.

O sistema é também consociativo, pois tem muitos atores com poder de veto. A Constituição detalhada força os governos a terem que aprovar constantes emendas constitucionais para implementar suas políticas, aliás, de difícil aprovação, pois necessitam de super-maiorias, tanto da Câmara quanto no Senado. O sistema partidário, por outro lado, não oferece canais de ação coletiva para os parlamentares, que estão segregados em mini-grupos (partidos fracos, grupos regionais, etc). O Executivo tem, assim, que negociar no varejo com 3/5 dos deputados e senadores - sempre ávidos em se apropriarem das finanças do governo para fazer políticas pork barrel - o que conduz a repetidas crises de governabilidade. Em resumo: o Brasil teria uma estrutura similar à da IV República francesa (Immergut, 1996) - basicamente ingovernável.

Desse modo, o sistema político é avesso seria reformas estruturantes, como a reforma tributária.

Como se pode ver, esses argumentos vão do sistema geral para o caso individual. A crer em seus termos, pode-se dizer: "o governo não consegue aprovar a reforma tributária porque o sistema político é fragmentado, descentralizado, confuso e consociativo". 
No entanto, o sistema não é nem fragmentado, nem confuso, nem descentralizado, nem consociativo. As teorias expostas acima são muito pouco embasadas empiricamente. Os analistas estavam dominados pelo pessimismo que acompanhava a crise econômica e social do final do regime militar e início da redemocratização, anos difíceis para o país, durante os quais tudo parecia estar errado no Brasil. Nesse contexto, qualquer opinião negativa (principalmente a respeito do sistema político) parecia ser verdadeira.

Talvez por isso, passada a instabilidade e consolidado o novo regime constitucional, o pensamento acadêmico sobre a estrutura política do Brasil começou a mudar. As pesquisas empíricas dos anos 90, claramente lideradas por Argelina Figueiredo e Fernando Limongi, mostraram um resultado totalmente diferente do esperado segundo as visões correntes da época. À despeito de todo o pessimismo dos intérpretes, do ponto de vista empírico, o sistema político foi visto como ordenado e previsível. De modo que, hoje, o sistema político brasileiro pode ser até considerado mais majoritário do que consociativo (Lijphart, 2003) (Limongi, 2006).

Enfim, nada autoriza a falar que as instituições do país são tendentes à ingovernabilidade. Ao contrário, o poder do Executivo brasileiro é pelo menos tão expressivo quanto o das democracias parlamentares europeias.

Limongi (2006) traz dois indicadores empíricos para corroborar tal afirmação: a taxa de sucesso e a taxa de dominância do Executivo ${ }^{34}$. No Brasil, de 1988 a 2006, as taxas de sucesso e dominância são de 70,7\% e 85,6\%, respectivamente (Limongi, 2006, pg. 23). Trata-se de um nível alto para um país considerado ingovernável. Na Inglaterra, exemplo de país parlamentarista e majoritário, os índices são de 93\% e 84\%, respectivamente. Na Dinamarca são de $89 \%$ e $99 \%$, ou de $88 \%$ e $97 \%$, de acordo com o período analisado. Na Finlândia, outro país que como o Brasil adota a RPLA, os índices são de $84 \%$ e $84 \%$, ou de $88 \%$ e $99 \%$, de acordo com o período analisado.

Com isso, vemos que o sistema brasileiro tem hegemonia do Executivo, e não ingovernabilidade. O sistema é majoritário, e não consociativo. Nem o legislativo nem os partidos são entraves aos projetos do Executivo.

\footnotetext{
${ }^{34} \mathrm{O}$ primeiro diz qual a porcentagem dos projetos legislativos do Executivo viram leis. Ou seja, do total de projetos que o Executivo propõe, quanto por cento é aprovado. Já a taxa de dominância é a composta pelo total de leis aprovadas de iniciativa do presidente sobre o total de leis aprovadas no parlamento. Ou seja, quanto por cento das leis aprovadas pelo parlamento é de iniciativa do presidente.
} 
Os motivos para a hegemonia do Executivo, descoberta pela literatura mais recente, segundo Figueiredo e Limongi (1999) e Limongi (2006) são: (1) prerrogativas legislativas exclusivas do Presidente, (2) poder de agenda do Presidente e dos líderes partidários e (3) poderes orçamentários do Presidente. Mais especificamente, os autores mostram que as instituições eleitorais não são os principais fatores a determinar o comportamento parlamentar dentro do legislativo. As tendências fragmentadoras das regras eleitorais são mais do que compensadas pela força centralizadora das regras internas do parlamento e dos poderes legislativos do chefe do Executivo. As instituições brasileiras foram, portanto, desenhadas para favorecer o presidente e a maioria legislativa, e não para atravancar o processo político.

Outra mudança “d'água para o vinho" nas interpretações foi a visão dos partidos. À despeito do voto pessoal e até mesmo de uma atuação individualista de muitos parlamentares nas eleições, o comportamento legislativo dos partidos é coeso e disciplinado.

Pereira e Muller (2003) observam 327 votações nominais no plenário da Câmara dos deputados (166 PECs e 161 "outras" votações) de 1995 a 1998. O resultado foi que os parlamentares que pertencem aos partidos que formam a coalizão de governo votam consistentemente de modo favorável ao governo (Pereira e Muller, 2003, pg. 747). Essa correlação é maior na votação de PECs do que nas "outras"; e maior nas medidas polêmicas do que nas medidas consensuais. Isso mostra que quando o governo realmente precisa da base, ela não o decepciona.

Uma pesquisa parecida que cobre um período maior (de Sarney ao primeiro mandato de Lula), Limongi (2006, pgs. 24 e 25), observa que a disciplina média da base do governo é de $87,4 \%$ (a análise é de 842 votações nominais no período). O presidente que teve o menor apoio foi Sarney com 78,4\% e o que teve maior apoio foi FHC 2, com $90,7 \%$ (Lula teve $89,1 \%$ ).

O apoio ao presidente é menor quando um dos partidos da base indica votos contrários à indicação do líder do governo. Nesses casos o índice de apoio é de 70,1\%. Isso demonstra que, em geral, a disciplina partidária não é quebrada. O governo não precisa negociar individualmente com os parlamentares. Ele precisa apenas garantir a coesão dos partidos de sua base.

De fato, com tamanha disciplina, o governo raramente é derrotado no plenário. Os presidentes venceram nada menos que $91,3 \%$ das matérias que disputaram (a medida 
já exclui votações consensuais, com menos de $10 \%$ de divergência, que poderiam aumentar ainda mais o índice). No caso das emendas constitucionais, que são mais exigentes para a aprovação, a porcentagem de vitórias está exatamente na média, foram 242 vitórias em 265 votações (91,3\%). Em seu segundo governo, Fernando Henrique obteve apoio do plenário em 31 das 32 votações e Lula, em 31 das 32 (Limongi, 2006, pg. 24).

Em suma: as evidências mostram que, para o presidente ser bem sucedido na sua agenda legislativa, precisa apenas montar uma base sólida - que seja, de pelo menos 3/5 dos parlamentares da Câmara e do Senado, uma vez que é necessário aprovar emendas à constituição - e negociar para que não existam muitas divergências com os partidos da coalizão governista. Em situações ordinárias, não é preciso negociar com a oposição (embora ela possa compensar eventuais defecções na base). Também não é necessário negociar com os parlamentares individualmente. Basta negociar com os líderes partidários, pois eles são fortes o suficiente para garantir o voto dos liderados.

Outro argumento acerca da ingovernabilidade do sistema político ressaltava a influência dos governos subnacionais, particularmente os governadores, no processo decisório federal (Abrucio, 1998) (Stepan, 1999). Esse é um argumento derivado da visão de que os parlamentares são preocupados com demandas localistas e não se preocupam com questões nacionais. Neste argumento, os governadores agiriam como atores de veto e impediriam os projetos do presidente.

Três pesquisas empíricas refutam tal hipótese: Carey e Reinhardt (2003), Arretche (2007) e Cheibub, Figueiredo e Limongi (2009).

Carey e Reinhardt (2003) estudaram 675 votações não consensuais entre 1986 e 1998. Segundo Abrúcio, essa foi a época do auge do estadualismo da Nova República, uma vez que os governadores foram beneficiados pelo desgaste do governo federal causado pelo fim do regime militar. Contudo, no decorrer desse período, as votações não seguiram nem o critério geográfico (bancadas estaduais coesas), nem o critério de apoio à opinião do governador. Ao contrário, as votações seguiram critérios partidários. Nas palavras dos autores: Não encontramos nenhuma comprovação para a explicação do reforço entre mandantes no que diz respeito à influência dos governadores no comportamento dos deputados - nenhuma "ajuda" do governador - em quaisquer especificações do nosso modelo (Carey e Reinhardt, 2003:793).

Marta Arretche (2007) analisou 275 votações nominais que contrapuseram os interesses da União aos das demais unidades federativas. O período de análise cobre 
quase todo o novo período constitucional (1989 a 2006). É interessante notar que nesse período a União conseguiu reverter em parte a descentralização promovida pela Constituição de 1988 - tanto do ponto de vista de re-centralização de receitas, como de imposição de restrições à autoridade subnacional. Desse modo, sobraram incentivos para os entes federados tentarem vetar medidas do governo nacional. Contudo, as clivagens apresentadas nas votações não são regionais, nem seguem a preferência do partido do governador. Mais uma vez, a clivagem é partidária. O índice de coesão partidária é tão alto nestas votações quanto é nas demais votações, sempre acima de 80\%. O índice Rice, de coesão das bancadas estaduais, só é alto quando a bancada estadual é majoritariamente do mesmo partido, o que demonstra que é o partido (e não a região ou o governador) o principal fator explicativo do comportamento parlamentar.

Para além dos números, é interessante o argumento de Arretche de que os próprios discursos parlamentares não tinham caráter federativo, mas ideológico. As clivagens diziam mais a respeito às diferentes concepções de Estado (em uma clivagem esquerda-direita) do que de relações federativas (Arretche, 2007, pg. 56 e 57).

Cheibub, Figueiredo e Limongi (2009) estudaram a hipótese de o partido do governador influir no voto dos parlamentares durante o período de 1988 a 2006. Contudo, não encontraram nenhuma evidência de que parlamentares governistas oriundos de estados governados pela oposição sejam menos fieis do que parlamentares de estados governados pela situação. Ao contrário, os deputados governistas de estados com governadores oposicionistas são levemente mais fieis do que os de estados governados por situacionistas. Esta conclusão é válida mesmo para questões "centralizadoras", onde os interesses dos estados se choca com os as propostas do governo federal. Ou seja, a conclusão geral desta análise é evidente: não há indicação de que os governadores sejam capazes de controlar as bancadas de seus respectivos estados (Cheibub, Figueiredo e Limongi, 2008, p. 288).

O interessante é que os autores encontraram evidências de que o regionalismo tem têm influência nas votações, mas pela via partidária. A chance de um parlamentar governista votar com o governo cai $40 \%$ quando o partido do governador de seu estado indica voto contrário na matéria - embora isto não anule a tendência geral dos parlamentares governistas votarem com o governo. Ou seja, o federalismo tem influência nas decisões dos parlamentares, mas em situações ordinárias elas não são fortes o suficiente para contrabalaçar as forças centralizadoras no parlamento. 
Nem mesmo a constituição detalhada do Brasil parece ser um entrave à governabilidade. A extensão e formato da constituição é um dos argumentos dos que defendem que o sistema brasileiro é consocialista e tem muitos atores com poder de veto (Mainwaring, 2001), (Stepan, 1999).

De fato, emendar a constituição é mais difícil do que mudar as demais leis. Mas comparativamente, a constituição brasileira é fácil de ser emendada ${ }^{35}$. Uma evidência é o número de emendas à constituição aprovadas de 1989 a 2008: 57, uma média de três por ano. Segundo Marta Arretche, a razão para tanto são as regras pouco exigentes para se aprovar uma emenda. Basta reunir uma maioria de 3/5 dos parlamentares na Câmara dos Deputados e no Senado, em uma votação de dois turnos separados por apenas cinco sessões. Arretche argumenta que nestes termos, a inceteza com relação à obtenção de maioria na segunda votação é praticamente zero (Arretche, 2008, pg. 35). Com isso, o Brasil se distingue de outras federações que colocam arenas de veto adicionais para o emendamento da Constituição ${ }^{36}$.

No Brasil, devido a esta grande fluidez constitucional, na verdade, a constituição é mais usada para fazer acordos de longo prazo do que servir de base para o sistema político (exceção feita às cláusulas pétreas, art. 60, § $4^{\circ}$ ). Convém lembrar que grande parte das emendas à Constituição são para criar artigos no Ato das Disposições Constitucionais Transitórias (ADCT), que são, como o nome diz, temporários. São exemplos deste uso instrumental da Constituição para criar acordos de médio e longo prazo o Fundef/Fundeb ${ }^{37}$ e o sistema FSE/FEF/DRU ${ }^{38}$.

A Constituição constrange as vontades dos governos, mas não são sérios obstáculos à vontade da maioria (no sentido de Demos-Constraining de Alfred Stepan) (Stepan, 1999). Com a gama de poderes do Presidente e da maioria parlamentar, a minoria estará apenas moderadamente equipada para se defender de um governo realmente determinado. A Constituição detalhada não é, portanto, causa de rigidez do sistema, ela é a consequência de sua fluidez. Os parlamentares sabem que o Executivo

\footnotetext{
${ }^{35}$ Segundo pesquisa de Lutz (1994), citada por Arretche (2008), a constituição brasileira é medianamente rígida, em comparação internacional

${ }^{36}$ Nos Estados Unidos é necessário o voto de uma maioria qualificada das assembléias estaduais. Na Suíça é necessário o referendo. Existem países onde só se pode aprovar uma emenda que vai valer para a próxima legislatura.

${ }^{37}$ Estas medidas criam fundos (de duração, respectivamente, de 10 e 14 anos) que redistribui os recursos de transferências intergovernamentais de acordo com o número de alunos matriculados nas redes escolares estaduais e municipais.

${ }^{38}$ Estas medidas flexibilizam temporariamente o orçamento federal prescrevendo uma porcentagem de recursos que está liberada das vinculações orçamentárias.
} 
tem grande liberdade para modificar a legislação ordinária. Por isto, lutam para proteger algumas políticas, colocando-as na Constituição.

Em suma: o sistema político brasileiro é muito centralizado, ordenado e majoritário. O presidente e os líderes partidários conseguem, em geral, aprovar seus projetos.

Note-se que isso torna ainda mais estranha a crônica paralisia da reforma tributária.

Não pode ser aceito o argumento dos que defendem que a reforma tributária mostra que o presidente não tem pleno controle sobre o sistema, pois um caso não pode explicar o sistema. Se o Executivo aprova $70 \%$ de tudo o que envia ao Congresso, não podemos dizer que estes $70 \%$ são a exceção e os $30 \%$ restantes são a regra. Também não é razoável esperar que o Executivo aprove tudo o que envia ao Congresso, pois não é assim que as democracias presidencialistas funcionam. O presidente não governa contra a maioria parlamentar, apesar de exercer grande influência sobre ela. O que se argumenta acima é apenas que (1) os custos de transação política são baixos, pois o processo de negociação é centralizado nas figuras do presidente e dos líderes partidários. E (2) as minorias parlamentares não têm muito poder - pelo menos não até se juntarem para formar uma maioria.

A estranheza no fracasso da reforma tributária só faz sentido, então, quando se olha o contexto. Quando se observa a grande insatisfação com o atual sistema de impostos e a comoção que isto gera. E também quando se observa que dois presidentes bem sucedidos enviaram três propostas ao Congresso e todas falharam.

Isso nos leva à última tese corrente para explicar o fracasso da reforma: o desinteresse do executivo. Marcus Melo $(1997,2005)$ argumenta que a reforma não foi bem sucedida por causa da resistência das burocracias fazendárias e orçamentárias. Iris Campos (2002) argumenta de forma parecida para explicar o insucesso da PEC 175/1995. Ela diz que a instabilidade econômica no final do mandato de Fernando Henrique Cardoso fez com que as prioridades mudassem das reformas estruturais para o ajuste fiscal de curto prazo, fazendo com que o governo abandonasse a reforma.

Esses argumentos podem ser rebatidos com críticas históricas e teóricas. Em primeiro lugar, deve-se considerar que as burocracias fazendárias e orçamentárias possuem limitado poder sobre o parlamento. Seu poder se situa dentro do poder 
Executivo, influenciando as propostas que o presidente envia ao congresso ou então dificultando ou facilitando sua implementação depois de aprovadas. Tanto no governo Lula quanto no governo FHC as reformas foram assinadas pelo ministro da fazenda, mostrando que elas tinham sido analisadas por aquele ministério.

No caso específico do governo Lula, os policy advocates das reformas foram os secretários do Ministério da Fazenda Bernad Appy e Arno Augustin. Esses funcionários, não apenas defenderam a proposta, como a redigiram em grande parte. Assim, se os presidentes enviaram a proposta ao parlamento é porque a resistência interna havia sido vencida. Uma vez que a proposta chega ao Congresso, o único poder que as altas burocracias têm é o poder de informar os parlamentares com seu conhecimento técnico sobre a tributação ${ }^{39}$. Não podemos negar que as dificuldades técnicas das propostas dificultaram seu sucesso, assunto que abordaremos mais à frente. Mas afirmar isto é diferente de reconhecer nas burocracias um ator com poder de veto.

As PECs não foram desenhadas para diminuir os recursos tributários. Ao contrário, poderiam aumentar a arrecadação com o fim da guerra fiscal. Todas as propostas aumentavam o poder do fisco, concedendo poderes especiais às máquinas arrecadatórias, aumentado as informações disponíveis sobre o sigilo fiscal ou alterando o sistema de cobrança dos impostos. Mesmo admitindo que as burocracias fazendárias são naturalmente conservadoras, é difícil acreditar que elas recusem mudanças que lhes tragam benefícios, mesmo que isso traga algumas descontinuidades para a administração tributária.

A postura do governo FHC, de ter abandonado sua proposta durante oito anos, não pode ser estendida ao governo Lula. Pelo menos no caso da PEC 41/2003, o governo mostrou alto interesse por ela, fazendo com que ela fosse aprovada nas comissões da Câmara e no plenário bem próximo aos seus tempos mínimos de tramitação. Para isso, ele se utilizou de todos os recursos à sua disposição: trocou parlamentares das comissões (inclusive das comissões permanentes), diminuiu o número de medidas provisórias nas proximidades das votações e liberou um grande número de emendas parlamentares nos dias próximos das votações. O governo chegou

\footnotetext{
${ }^{39}$ A mobilização da alta burocracia é diferente da mobilização da burocracia de nível baixo e médio. Enquanto as altas burocracias procuram agir diretamente sobre as lideranças políticas, as burocracias de nível inferior procuram se utilizar da ação coletiva. Apesar do sindicato dos fiscos estaduais (Fenafisco) ter lançado alguns folhetos críticos às reformas, não houve mobilização efetiva contra ela (greve, ameaça de greve).
} 
até a editar uma medida provisória anulando uma outra que estava trancando a pauta do congresso, o que provocou a ira da oposição e questionamentos jurídicos da ação. Somente quando a proposta chegou ao Senado é que a reforma se inviabilizou ${ }^{40}$. A PEC 233/2008 também foi rapidamente aprovada nas comissões, mas se inviabilizou no plenário. A postura do governo Lula foi bem diferente da do governo FHC, que deixou a reforma tramitar quatro anos na Comissão Especial. E mesmo isso não pode ser creditado a um suposto desinteresse pela proposta. A postura do governo FHC foi fruto de uma mudança de estratégia. O governo, vendo as dificuldades por que passava a PEC 175/1995, resolveu selecionar alguns pontos chaves de alto consenso para serem modificados por lei complementar. Isto resultou na aprovação das três Leis Kandir em 1995 e 1996. A Lei complementar 87 de 1996 (única que oficialmente recebeu a alcunha “Lei Kandir”), continha muitos pontos semelhantes à PEC 175/1995, como a desoneração das exportações e do ativo fixo das empresas.

Assim, o desinteresse do executivo na proposta não foi motivo do seu fracasso. O que aconteceu foi o contrário: o fracasso da reforma provocou o desinteresse do executivo. O governo Fernando Henrique Cardoso foi muito ativo no campo tributário e fiscal, mas concentrou sua ação nas leis infraconstitucionais. O primeiro governo Lula foi o único que resolveu jogar todas as fichas na reforma constitucional, resultando em uma vergonhosa derrota para o presidente. O segundo governo Lula não foi tão ativo, evitando colocar a proposta no plenário antes de um firme consenso com a base aliada consenso este que até o momento não existe. O resultado é a lacônica frase do presidente: não acredito mais em reforma tributária ${ }^{41}$.

Assim, a resposta para o fracasso das reformas tributárias não pode ser buscada nem no sistema político, nem no sistema federativo e nem mesmo em uma suposta falta de empenho do presidente ou dos burocratas. O problema está na própria proposta do governo e na relação dela com a estrutura econômica e institucional existente.

\footnotetext{
${ }^{40}$ E mesmo o Senado não parece ser o único problema da reforma, pois as PECs 175/1995 e 233/2008 falharam na Câmara dos Deputados. Também é de se ressaltar que a PEC 41/2003 não foi derrotada nem no plenário nem em nenhuma comissão do Senado. Foi o relator da proposta na Comissão de Assuntos Econômicos (CAE), Senador Aloysio Mercadante (PT-SP), que resolveu "fatiar" a proposta, enviando os pontos de consenso para o plenário e devolvendo os pontos polêmicos para a Câmara dos Deputados. Assim, existem outros problemas para a tramitação das propostas além de uma eventual dificuldade do governo Lula no Senado.

41،“Não acredito mais em reforma tributária', afirma presidente”. UOL notícias, disponível em: http://noticias.uol.com.br/ultnot/multi/2009/09/15/0402386ADC813366.jhtm?nao-acredito-mais-emreforma-tributaria-afirma-presidente-0402386ADC813366 (acessado em 10/10/2009).
} 
Abaixo será mostrado como as propostas envolviam muitos interesses e coalizões políticas distintas. Apesar de os custos de transação não serem altos no Brasil, existe um limite ao número dimensões que os reformadores podem negociar, ao número de interesses opostos (clivagens) a conciliar. As reformas amplas criam um problema de múltiplas dimensões políticas (Estado vs. contribuintes; estados ricos vs. estados pobres; União vs. estados; etc). Essa multidimensionalidade é o verdadeiro segredo do insucesso da reforma. 


\section{3- Clivagens e Dimensões}

\section{1- O que é Multidimensionalidade}

O objetivo deste capítulo é explicar formalmente o que é multidimensionalidade e por que ela atrapalha a aprovação de mudanças constitucionais.

O uso de modelos formais para a análise política teve seu início na década de 1950 com os trabalhos seminais de Arrow (1951), Downs (1999[1957]) e Black (1958). Na década de 60, houve o primeiro uso de modelos geométricos para a análise de duas ou mais propostas políticas simultâneas, principalmente a partir do trabalho de Plott (1967). Com o desenvolvimento da teoria dos jogos e da chamada "teoria da escolha social" (social choice theory), a análise espacial do voto se desenvolveu consideravelmente (McKelvey, 1976, 1979) (Shepsle, 1979) (Riker, 1980) (Shepsle \& Weingast, 1981) (Krehbiel , 1988) (Ordeshook, 1993). Abaixo usaremos algumas ferramentas desta teoria, mas não carregaremos o leitor com a formalização matemática típica desta tradição.

Por "dimensão", entendemos um tema (issue) ou uma questão política que pode ter valor maior ou menor. Podemos citar como exemplo a centralização ou descentralização das competências federativas, uma carga tributária maior ou menor, flexibilidade vs. rigidez administrativa, maior controle estatal vs. maior controle do mercado e assim por diante. A referência geométrica (dimensão) não é gratuita. Podemos pensar em um modelo simplificado onde uma questão ou proposta é representada por um eixo euclidiano unidimensional.

Abaixo está um exemplo dessa analogia. As diferentes opiniões sobre o tamanho da carga tributária são representadas pelo eixo. Quando mais à direita, maior a preferência pela alta carga tributária e quanto mais à esquerda, menor a tolerância à alta carga tributária. Suporemos que neste eixo se distribuem três partidos e que é necessário o acordo da maioria para mudar o status quo.

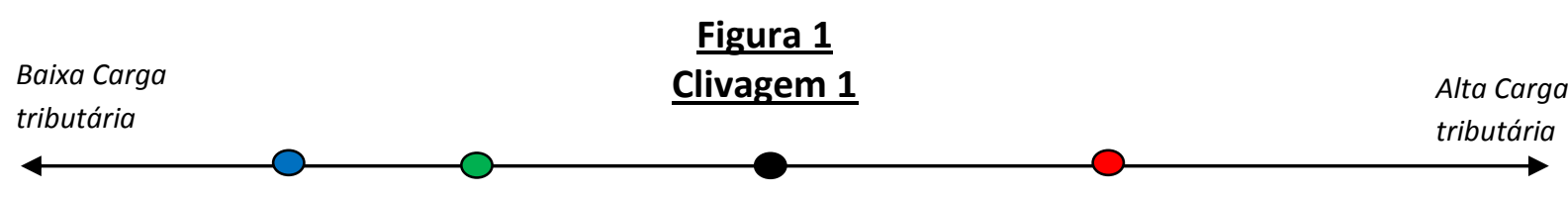

Partido 1 Partido 2

Status Quo

Partido 3 
No exemplo acima, os partidos 1 e 2 podem propor uma mudança do status quo para aproximá-lo de suas preferências. Partiremos do pressuposto de que os atores querem a situação mais próxima possível de suas preferências em qualquer direção. Assim, o partido 3 prefere o status quo a qualquer mudança proposta pelos demais partidos. Para evitar dúvidas, diremos que existe uma "clivagem" política quando pelo menos um ator prefere o status quo a uma mudança sugerida.

Seguindo Tsebelis (1995) e outros teóricos da distribuição espacial do voto, denominaremos de "winset" a zona onde os partidos podem chegar a acordos. Na representação abaixo ela é representada pela área amarela ${ }^{42}$.

\section{Figura 2}

\section{Clivagem 1}

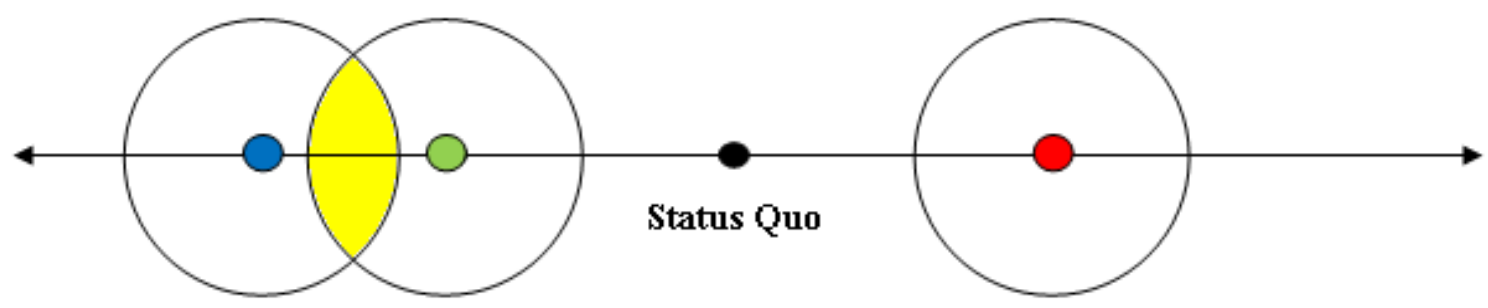

Em outra questão, como, por exemplo, sobre se o sistema tributário deve ser centralizado ou descentralizado, os mesmos partidos podem ter outra distribuição de preferências. Nesse caso, os partidos 2 e 3 poderão chegar a um acordo e mudar o status quo. O partido 3, então, fará a oposição.

\section{Figura 3}

\section{Clivagem 2}

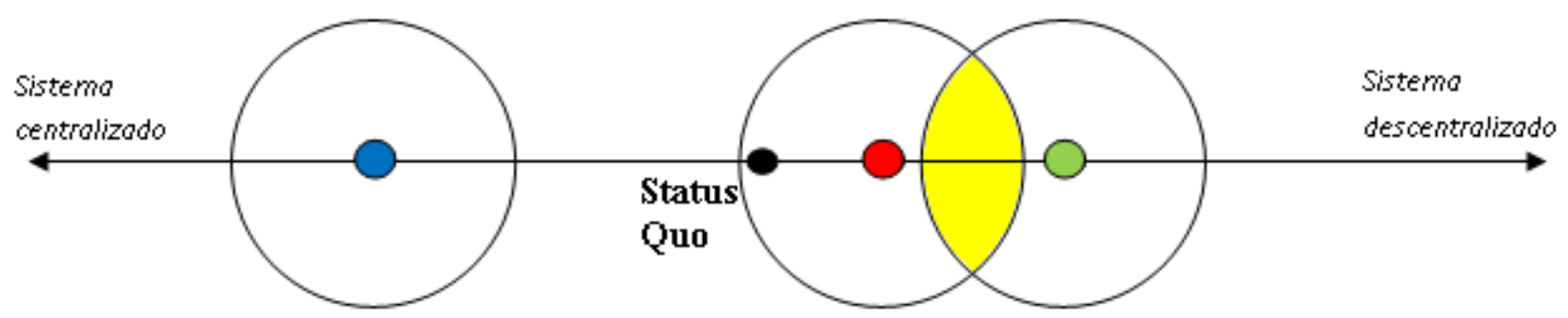

\footnotetext{
42 Para facilitar a visualização, há círculos em volta das áreas de preferências dos atores mesmo em representações unidimencionais.
} 
Porém, quando os partidos analisam as duas propostas conjuntamente, não há nenhum winset onde uma maioria pode chegar a um acordo. Neste caso, o status quo permanece inalterado. Repare que na figura 4 todos preferem a situação atual às propostas uns dos outros, embora suas posições ideais estejam bastante distantes do status quo.

\section{Figura 4}

\section{Clivagens 1 e 2}

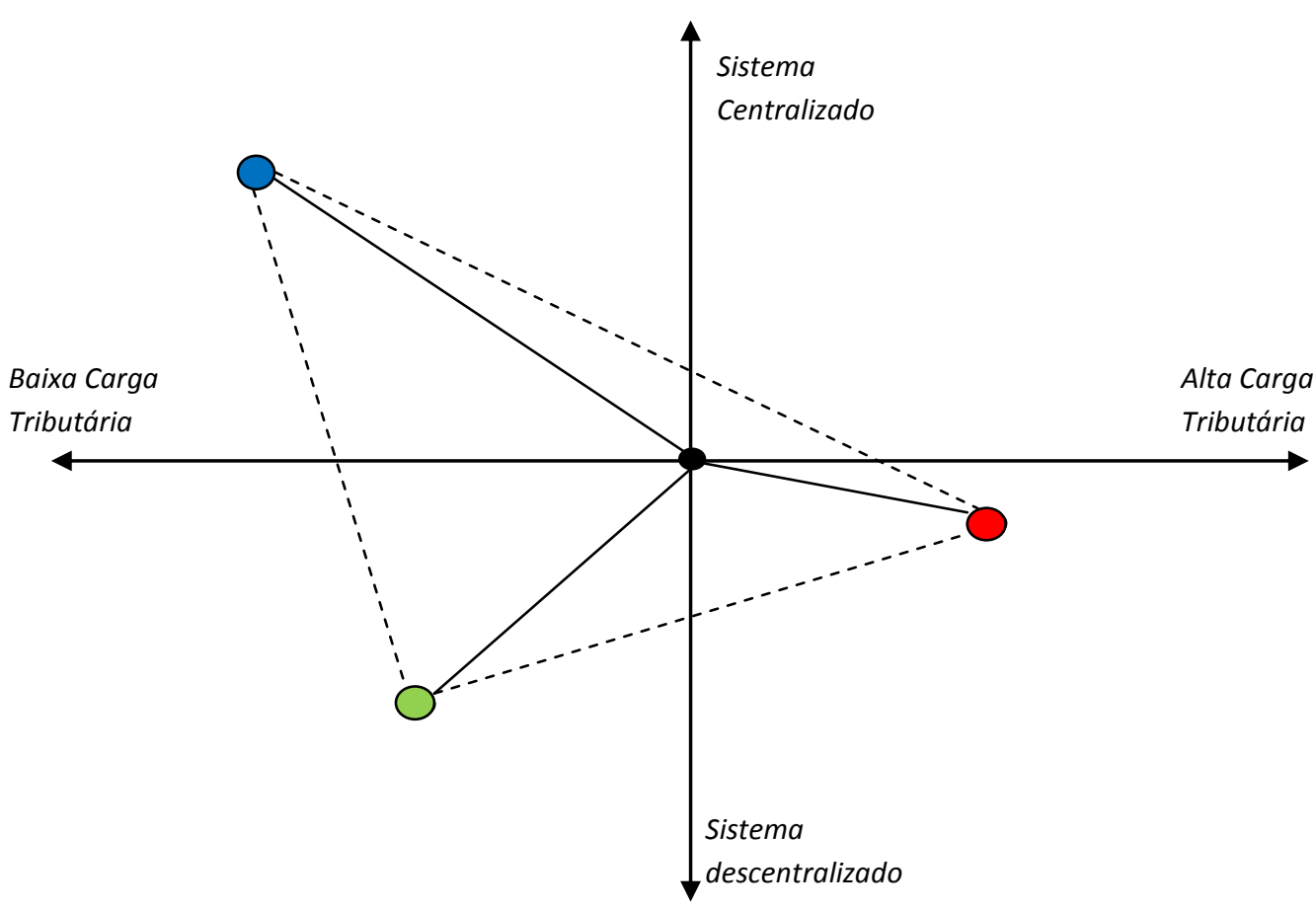

Assim, a análise das duas questões conjuntamente (nível da carga tributária e centralização do sistema), dificulta a alteração do status quo.

McKelvey $(1976,1979)$ mostrou que quando se analisa duas questões ao mesmo tempo, perde-se um dos pressupostos da teoria da escolha racional: a transitividade das preferências. Para atores racionais, quando se prefere maçãs a laranjas e laranjas a limões, prefere-se maçãs a limões. Em termos formais: se $A>B$ e B>C; então A>C. Essa propriedade simples é o que garante que exista um "ótimo", uma posição ideal, para as preferências dos atores racionais. Em situações unidimensionais, essa regra da racionalidade individual se transfere para as decisões em grupo. É o chamado "teorema do eleitor mediano". Podemos observar isto na tabela VI. Cada jogador possui um valor ideal para cada tema (issue). Caso os temas forem analisados individualmente, os 
acordos são possíveis. No caso do tema A, os jogadores 2 e 3 possuem preferências maiores do que o status quo, então eles poderão chegar a um acordo para mudar a ordem das coisas. O winset possível será entre 90 e 110, pois o jogador 2 preferiria a situação vigente a um valor maior ou igual a 111 . No caso do tema B, seguindo o mesmo raciocínio, os jogadores 1 e 2 poderão mudar a situação para algo entre 80 e 70 . A ordem das escolhas é irrelevante. Tanto faz decidir sobre o tema A primeiro ou decidir sobre o tema B primeiro. Nos dois casos o resultado será o mesmo.

\begin{tabular}{|c|c|c|}
\hline \multicolumn{2}{|c|}{ Tabela VI - Decisões multidimensionais } \\
\hline & & \\
\hline & Tema A & Tema B \\
\hline Jogador 1 & 40 & 80 \\
\hline Jogador 2 & 90 & 40 \\
\hline Jogador 3 & 120 & 140 \\
\hline Status Quo & 70 & 90 \\
\hline
\end{tabular}

Mas o que acontece se os jogadores tiverem que apreciar a duas propostas ao mesmo tempo? Podemos representar isto através de um gráfico cartesiano bidimensional.

Figura 5 - Decisão sobre dois temas

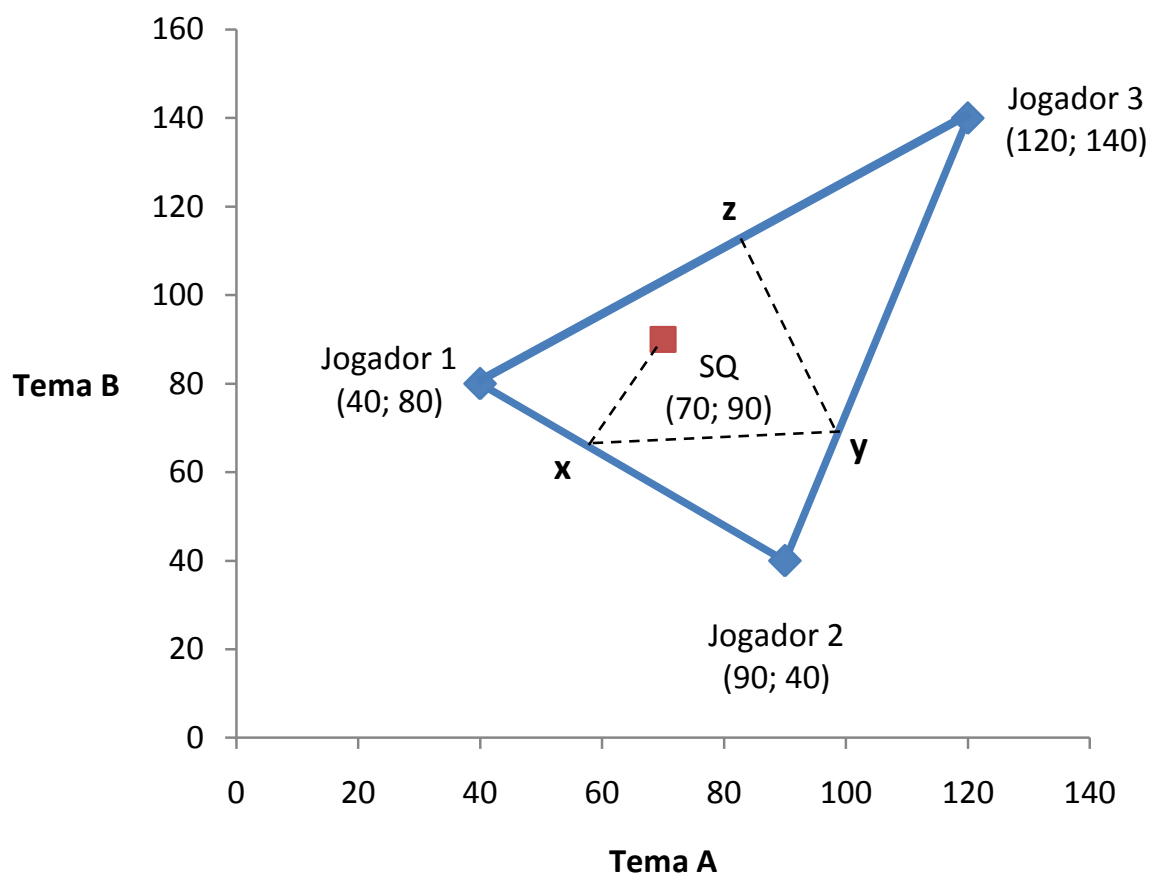


McKelvey $(1976,1979)$ argumenta que essa situação pode levar a um "cliclo majoritário", pois a regra da maioria leva a uma situação de intransitividade. Por exemplo, caso a proposta "x" seja feita, ela terá o apoio dos jogadores 1 e 2 , mudando o status quo. Porém, ela poderá ser superada pela proposta "y", com o apoio dos jogadores 2 e 3 . Novamente a proposta "z" superará a proposta "y" com o apoio dos jogadores 1 e 2 . O estranho é que a proposta "x" pode superar a proposta " $\mathbf{z}$ ", com o apoio dos jogadores 2 e 3 . Facilmente podemos ver que tal situação poderia se estender ao infinito, pois para qualquer ponto, sempre haverá uma maioria que o supere. Ou seja, decisões coletivas multidimensionais abrem caminho para a intransitividade das preferências.

Os artigos de McKelvey, além de mostrar a dificuldade de se decidir em situações multidimensionais, também foram importantes para revelar a importância do poder de agenda. Um ator que tenha o monopólio da criação de propostas poderia trasformar qualquer ponto do status quo em seu ponto ótimo. Assim, o poder absoluto de agenda equivale a poderes ditatoriais.

A descoberta do ciclo de votações majoritáriárias levou ao colapso das teorias que acreditavam que a simples agregação de preferências levava à formação da política $^{43}$. Riker (1980) argumentou que o ciclo majoritário mostrava que não havia nenhum equilíbrio único a se prever, e que a resposta para os resultados das políticas estava em outro lugar: nas instituições políticas. São elas que, por exemplo, controlam o poder de agenda para que os atores não voltem a estaca zero após cada votação. Elas reduzem as infinitas possibilidades de agregação de preferências, possibilitanto o surgimento de maiorias estáveis. Shepsle (1979) e Shepsle \& Weingast (1981), mostraram que o ciclo majoritário acontece com atores interagindo na ausênica completa de instituições (institution-free), ou seja, no estado de natureza hobbesiano. Em situações reais existe um "equilíbrio induzido pelas instituições", o que levou a criação da tradição da ciência política que inspirou o segundo capítulo deste livro: o institucionalismo.

Não adentraremos demasiadamente na história do institucionalismo. Para nossos propósitos, vamos ater-nos apenas a esta descoberta fundadora da teoria: a votação multidimensional leva a problemas de winset vazio ou de ciclos majoritários (que na

\footnotetext{
${ }^{43}$ Estas teorias eram chamadas de behavioristas ou pluralistas, dependendo da tradição a qual pertenciam (Immergut, 2006).
} 
prática representam a mesma coisa). Apesar de se estar discutindo aqui sobre o caso específico da reforma tributária, o argumento vale para qualquer regra democrática. A muldimensionalidade dificulta a formação de maiorias. As instituições podem amenizar este problema através do controle de poder de agenda, mas podem não resolvê-lo.

Contudo, não é verdade que a mera adição de uma nova dimensão na questão diminui o winset. Isso irá depender das preferências dos atores. Teoricamente é possível que as chances de aprovação da proposta não se alterem com a inclusão de um tema

\section{Figura 6}

\section{Clivagem 4}

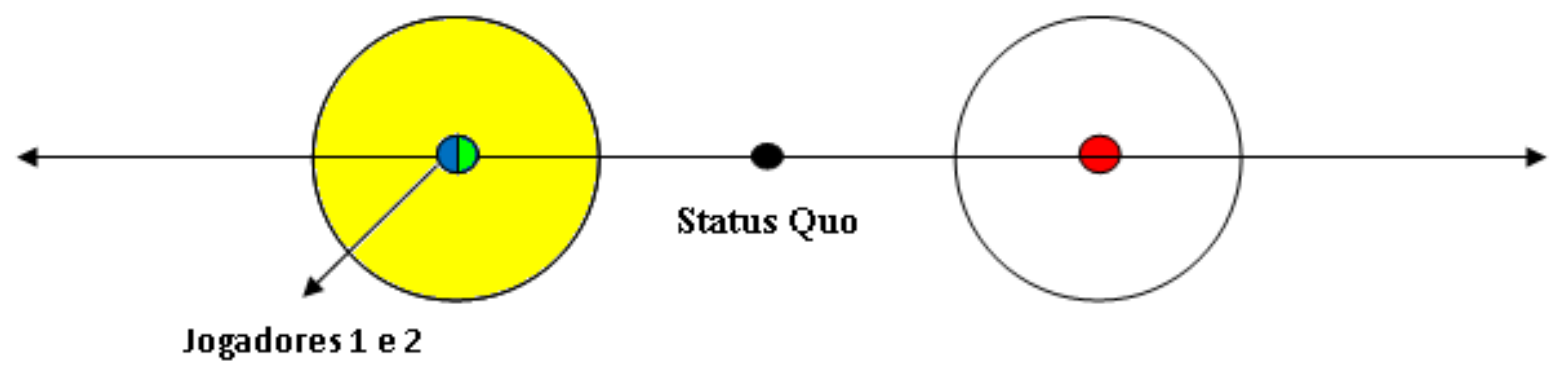

Figura 7

Clivagens 1 e 4

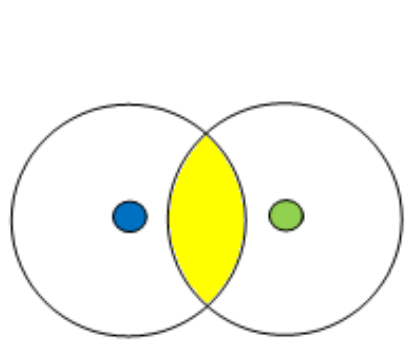

Status Quo

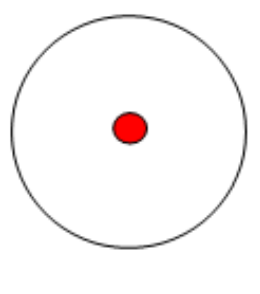


adicional. Isso acontece quando os atores que faziam parte da coalizão de apoio à alteração do status quo no eixo inicial também preferem a mesma alteração no eixo adicional. Istoé o que se pode ver nas figuras 6 e 7 .

Para haver a reprodução da mesma clivagem política, não é necessário que a posição dos atores seja rigorosamente igual (como no caso da figura 6), basta que ambos os atores prefiram uma alteração comum ao status quo.

Nesse caso, a nova dimensão não cria uma nova clivagem, ela reproduz a clivagem antiga. Trata-se de uma conclusão importante. Ela justificará o argumento do próximo capítulo: a inclusão de novas propostas não gera o problema da multidimensionalidade, desde que as clivagens políticas sejam as mesmas.

Conclusão: a decisão política em dois ou mais temas simultâneos pode impedir a alteração do status quo, pois os atores previamente acordantes em uma dimensão podem estar em desacordo em outra dimensão, causando problemas de winset vazio ou de ciclos majoritários. Podemos fazer o mesmo raciocínio com $\mathrm{N}$ eixos e com $\mathrm{M}$ atores, desde que $\mathrm{N} \geq 2$ e $\mathrm{M} \geq 3$.

Esse modelo que funciona bem para o "voto sincero", ou seja, quando os atores têm uma opinião e cegamente buscam maximizá-la. Poder-se-ia argumentar, certamente, que essa visão ignora dois aspectos relevantes da ação política: (a) a capacidade dos atores de antecipar as reações uns dos outros e (b) a capacidade de negociação política. No entanto, acreditamos que isso não invalida o argumento geral da multidimensionalidade.

\section{2 - Clivagens e Negociação}

Podemos sofisticar o modelo exposto acima admitindo que os atores são capazes de negociar. A negociação é uma forma comum de superar impasses políticos ${ }^{44}$. Se os

\footnotetext{
${ }^{44}$ A literatura de língua inglesa chama este processo de log-rolling (conluio). Ver Ferejohn (1986), Marshall \& Weingast (1988) e Gilligan \& Krehbiel (1994)
} 
agentes valoram diferentemente as propostas políticas, eles podem negociar de modo a saírem ganhando.

Podemos pensar em um partido feminista e um partido esportista. As feministas não apreciam muito o projeto dos esportistas e os esportistas não são nem um pouco fãs dos projetos das feministas. A Tabela VI mostra uma distribuição hipotética dos ganhos para ambos os partidos:

\begin{tabular}{|l|c|c|}
\hline \multicolumn{3}{|c|}{ Tabela VI - Clivagens entre feministas e esportistas } \\
\hline & Feministas & Esportistas \\
\hline Projetos para as mulheres & 15 & -5 \\
\hline Projetos para o esporte & -2 & 10 \\
\hline
\end{tabular}

O que se conclui de tal situação é que, se for necessário o voto favorável de ambos os partidos para a aprovação de uma proposta e os dois votarem sinceramente, ambos sairão perdendo, pois as feministas não votarão no projeto dos esportistas e os esportistas não votarão nos projetos das feministas.

Contudo, eles podem negociar para um votar no projeto do outro. Nesse caso, ambos sairão ganhando. As feministas votariam no projeto dos esportistas, mesmo que isto lhes cause um desprazer de -2 . Elas fariam isso porque a aprovação dos projetos para as mulheres lhes traz um bônus de 15, fazendo com que seu saldo líquido seja de 13. Da mesma forma, os esportistas podem votar no projeto das feministas e, se elas votarem favoravelmente nos projetos para o esporte, eles terão o saldo líquido positivo de 5. O saldo final da transação seria o aumento do bem-estar dos partidos em 18. Enquanto, se não houver transação, a situação fica no zero a zero.

De certa forma, a multidimensionalidade é o que possibilita a troca política. Em um mundo unidimensional só podemos trocar maçãs por maçãs (o que seria irracional). O mundo multidimensional é que permite trocar maçãs por laranjas ou morangos. Isso sempre é possível quando os atores apreciam ou rejeitam com intensidade diferente os temas (Shepsle \& Weingast, 1994).

Pensando na reforma tributária, o governo poderia fazer o seguinte cálculo: se o governo prorrogar a CPMF, haverá um "custo" em termos de desagrado aos contribuintes, mas haverá um benefício em termos de equilíbrio orçamentário e 
ampliação do gasto do governo. Então, o valor esperado da proposta "prorrogar a CPMF" é calculado da seguinte forma:

Proposta 1a: prorrogar a CPMF

Custo: $x$

Benefício: $y$

Valor da proposta: $w$

Sendo $\mathrm{w}=y-x$

Porém, os parlamentares observarão que eles ficariam com o ônus de ter votado a prorrogação de um imposto e o bônus da proposta ficaria com o Executivo. Então eles exigiriam contrapartidas para votar junto com o governo, como, por exemplo, liberar emendas ao orçamento para projetos destinados às bases políticas locais e aumentar o salário mínimo. Do ponto de vista do presidente, o valor da proposta seria o seguinte:

Proposta 1b: prorrogar a CPMF, liberar emendas para as bancadas e se comprometer a aumentar o salário mínimo.

Custo: $x+a$

Benefício: $y+b$

Valor da proposta: $w-c$

Sendo $c=b-a$

No modelo, "a" é o custo de se atender às demandas dos parlamentares, "b" os dividendos políticos que as propostas dos parlamentares trazem para o próprio Executivo e $c$ o saldo político das concessões ${ }^{45}$. Seria racional para o governo continuar a fazer concessões até $w=c$.

\footnotetext{
${ }^{45}$ Eventualmente, pode ser que o governo descubra que W-c é maior do que W (valor de c negativo). As concessões tornaram o projeto melhor do que o original. São as eventuais gratas surpresas que o governo encontra, situações onde o executivo pode dizer, orgulhoso, que o legislativo "aperfeiçoou a proposta". Isto é perfeitamente factível e será exemplificado na reforma do judiciário e na reforma administrativa no próximo capítulo. A teoria política "do lado da oferta" (Shepsle \& Weingast, 1994) mostra que as
} 
Uma ameaça crível também pode produzir os mesmos efeitos de uma concessão. Caso o governo ameace os parlamentares que votarem contra o projeto de demitir os funcionários indicados por eles nos ministérios, haverá alteração nos ganhos e perdas relativos de ambos os lados (lembrando que ameaças também têm custos e benefícios).

Formalmente, as concessões criam novas propostas, pois elas mudam a distribuição das preferências, possibilitando os acordos:

\section{Figura 8}

\section{Clivagem 5 (sem acordo)}

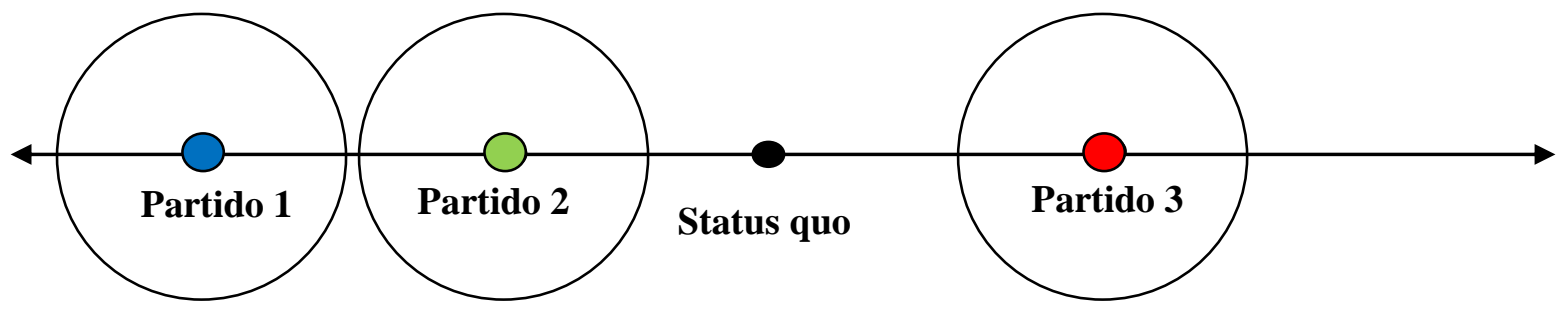

Figura 9

\section{Clivagem 5 (com acordo)}

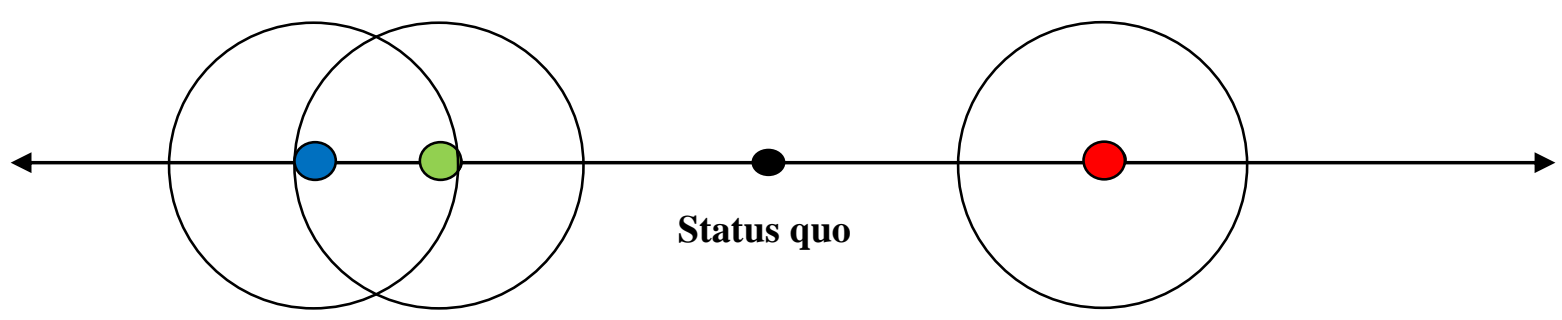

Porém, no mundo real, as negociações são imperfeitas. Os ganhos de um ator não são iguais às perdas do outro ator. Há uma parte do bem-estar dos jogadores que é simplesmente perdida, os chamados "custos de transação" (Coase, 1937) (North, 1990) (Marshall \& Weingast, 1988).

Voltando ao exemplo dos esportistas e das feministas. Podemos pensar em um custo de 2 para a transação, distribuído igualitariamente entre ambos os atores (o que não ocorre necessariamente na prática). Então temos: 


\begin{tabular}{|l|c|c|}
\hline \multicolumn{3}{|c|}{ Tabela VII - Clivagens entre feministas e esportistas e } \\
\hline & custo de transação \\
\hline & Feministas & Esportistas \\
\hline Projetos para as mulheres & 15 & -5 \\
\hline Projetos para o esporte & -2 & 10 \\
\hline Saldo (s/ custo de transação) & 13 & 5 \\
\hline Custo de transação & -1 & -1 \\
\hline Saldo (c/ custo de transação) & 12 & 4 \\
\hline
\end{tabular}

Os custos de transação são os recursos gastos para se conseguir chegar à colaboração. Eles não ficam com nenhum dos atores, eles são simplesmente perdidos como a ineficiência do processo. No exemplo acima, o ganho do acordo das feministas e dos esportistas diminuiu de 18 para 16. Caso o custo de transação dos esportistas fosse maior do que 5, eles não teriam motivos para fechar um acordo e a transação simplesmente não ocorreria.

Da mesma forma, no outro exemplo citado (a aprovação da CPMF), o valor real da proposta não é apenas $w-c$, mas $w-c-z$, sendo " $z$ ” o custo de transação envolvido.

O problema do custo de transação afeta tanto as trocas no mercado quanto as trocas políticas. Os principais motivos para a existência dos custos de transação na política são:

(a) Tempo de negociação dos governantes: os governantes costumam ter um tempo muito escasso. Eles não podem gastar dias ou meses para chegar a um acordo.

(b) Carência de informação: nem os custos nem os benefícios das medidas são claros. Voltando ao caso das feministas e dos esportistas. Há o risco de os benefícios serem menores do que o esperado (as mulheres não valorizaram muito os projetos das feministas) ou os custos serem maiores do que o esperado (as mulheres serem mais avessas ao projeto dos esportistas do que o esperado). Para evitar estes problemas, feministas e esportistas pedem mais do que o que o seu "projeto mínimo", pois querem maximizar as chances de seus eleitores lhes trazerem apoio. Como a informação é escassa, se os atores acreditam que é necessário $a$ para compensar as perdas de uma medida, vão 
pedir $a+v$, sendo " $v$ " o "colchão" de segurança para minimizar os riscos da operação. Como ambos pensam assim, o "custo" de ambas as propostas é aumentado.

(c) Problema do "risco moral": ambos os atores podem temer que o parceiro da negociação não cumpra sua parte do acordo. Então, um custo é embutido na operação para compensar o risco. Os atores podem adotar medidas para reduzir o risco moral, como fechar contratos, pedir garantias, manifestações públicas de apoio, etc. Todo o gasto que isso representa deve ser descontado do ganho final da operação.

Em casos em que os benefícios e as perdas são claros, os parceiros são totalmente confiáveis e a negociação pode ser feita rapidamente os custos de transação são mínimos e a transação é eficiente. Porém, nem sempre isso acontece na política e ou na economia.

$\mathrm{O}$ custo de transação cresce à medida que aumenta o número de atores em jogo (custo marginal crescente), pois a ampliação dos negociadores amplia o tempo de negociação, a necessidade de busca de informação e as precauções contra o risco moral. Por isso é que a centralização do poder no parlamento diminui os custos de transação. A negociação com as lideranças partidárias é menos custosa do que a negociação com parlamentares individualistas (Immergut, 1996)

Em cada nova proposta em que não há acordo, o proponente precisa fazer concessões e absorver o custo de transação. Se a reforma tem cinco propostas polêmicas, haverá a necessidade de negociar cinco concessões, conforme mostra a tabela VIII.

\begin{tabular}{|l|c|c|c|}
\hline \multicolumn{3}{|c|}{ Tabela VIII - Custo de uma reforma com cinco propostas } \\
\hline & Ganho primário & Conceções & Custo de transação \\
\hline Proposta 1 & $\mathrm{w}_{1}$ & $\mathrm{c}_{1}$ & $\mathrm{z}_{1}$ \\
\hline Proposta 2 & $\mathrm{w}_{2}$ & $\mathrm{c}_{2}$ & $\mathrm{z}_{2}$ \\
\hline Proposta 3 & $\mathrm{w}_{3}$ & $\mathrm{c}_{3}$ & $\mathrm{z}_{3}$ \\
\hline Proposta 4 & $\mathrm{w}_{4}$ & $\mathrm{c}_{4}$ & $\mathrm{z}_{4}$ \\
\hline Proposta 5 & $\mathrm{w}_{5}$ & $\mathrm{c}_{5}$ & $\mathrm{z}_{5}$ \\
\hline Total & $\sum \mathrm{w}$ & $\sum \mathrm{c}$ & $\sum \mathrm{z}$ \\
\hline
\end{tabular}


Assim, o aumento do número de clivagens amplia a quantidade de negociações. Como resultado, o custo de transação aumenta mais do que proporcionalmente, pois a capacidade de tomar decisões tem rendimento marginal decrescente. Em outras palavras, em cada nova negociação, os custos de transação aumentam, pois o rendimento dos negociadores diminui $\left(\mathrm{z}_{5}>\mathrm{z}_{4}>\mathrm{z}_{3}>\mathrm{z}_{2}>\mathrm{z}_{1}\right)$

\section{Figura 10 \\ Número de negociações e custo de transação}

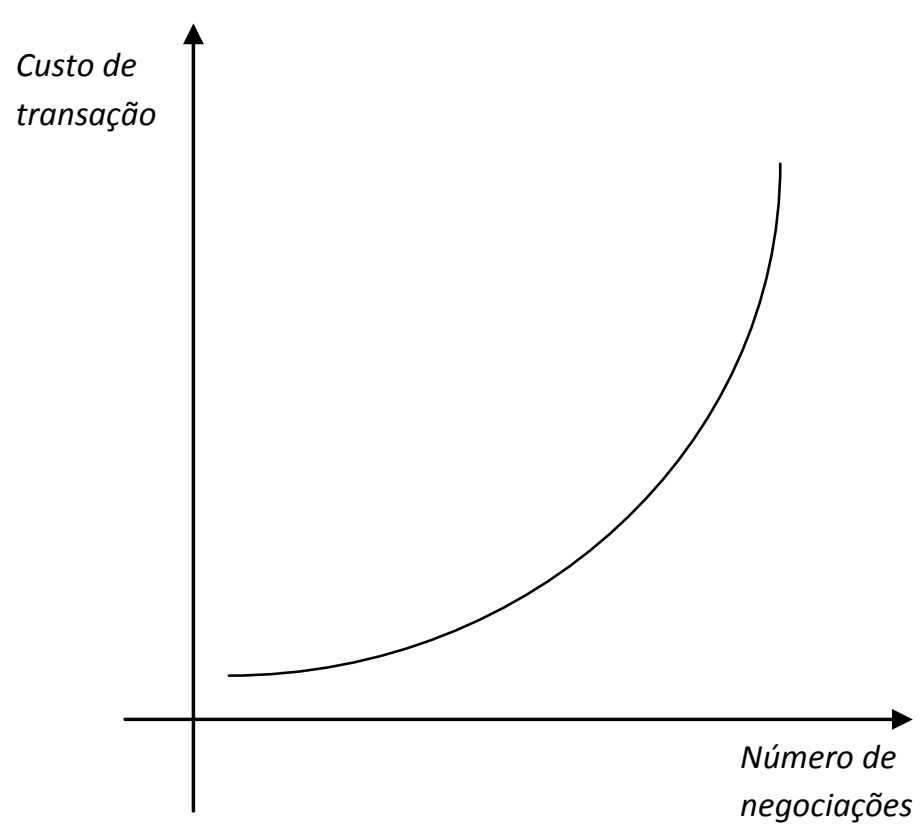

Contudo, não é verdade que a mera adição de uma proposta a uma reforma aumenta seus custos. É possível que todos os atores envolvidos sejam a favor da proposta e não seja necessário concessões para sua aprovação. Então teríamos uma situação parecida com a figura VII do item anterior (que representa a conjunção das clivagens 1 e 4), na qual a adição de um eixo unidimensional não diminuiu o winset. Nesse caso, a adição de uma proposta não representa a criação de uma clivagem, pois os atores previamente acordantes preferem a proposta ao status quo.

A multidimensionalidade causa a diminuição do winset quando a inclisão de uma dimensão cria uma clivagem interna à coalizão de apoio à proposta inicial. A criação de propostas adicionais pode não diminuir as chances de acordo, desde que elas sejam de consenso. Nesse sentido, note-se que o argumento deste trabalho é justamente 
que a reforma tributária falhou porque tinha muitos pontos conflituosos dentro da própria coalizão de governo e não simplesmente porque havia muitos pontos.

Conclusão: apesar de a negociação ser uma forma útil de superar impasses políticos, os negociadores não podem negociar indefinidamente, pois a própria negociação tem um custo. Assim, uma proposta com muitos pontos polêmicos pode se tornar inviável.

\section{3- Clivagens e formação de preferências}

Por fim, é importante considerar mais um ponto: o modo como os parlamentares escolhem suas preferências.

Assumiremos aqui que a opinião política possui uma bidimensionalidade intrínseca. Por um lado, existe a política como forma de se atingir ideais coletivos de mundo e de sociedade. Os eleitores frequentemente se dispõem a pagar mais impostos para proteger florestas que nunca visitaram, baleias que nunca viram, enfermos que não conhecem, etc. Por outro, a política é uma forma de apropriação e distribuição de bens privados. Os eleitores também pressionam o governo para proteger e ampliar suas rendas e direitos. No próximo capítulo mostraremos como essas duas dimensões frequentemente entram em contradição.

O diagrama abaixo (figura 11) mostra que os parlamentares precisam formar sua opinião em uma situação muito difícil. Seus stakeholders principais, os eleitores, impõem-lhes um duplo (e contraditório) mandato: a busca de bens públicos e de bens privados. Ademais, os parlamentares também são pressionados pelos líderes partidários, pelo Executivo, pelos outros parlamentares e pelo seu próprio ideal de bem público.

Neste trabalho focaremos mais em um dos elos da cadeia: o elo que liga os interesses próprios dos eleitores à posição dos parlamentares. Infelizmente, ainda não há uma boa teoria na ciência política sobre como se formam as opiniões dos parlamentares e eleitores no que respeita aos ideais coletivos. Assumiremos que os problemas do sistema tributário apresentados no capítulo 2 já seriam suficientes para mover o espírito público da sociedade brasileira rumo à reforma tributária, restando o entrave nos interesses particulares. 


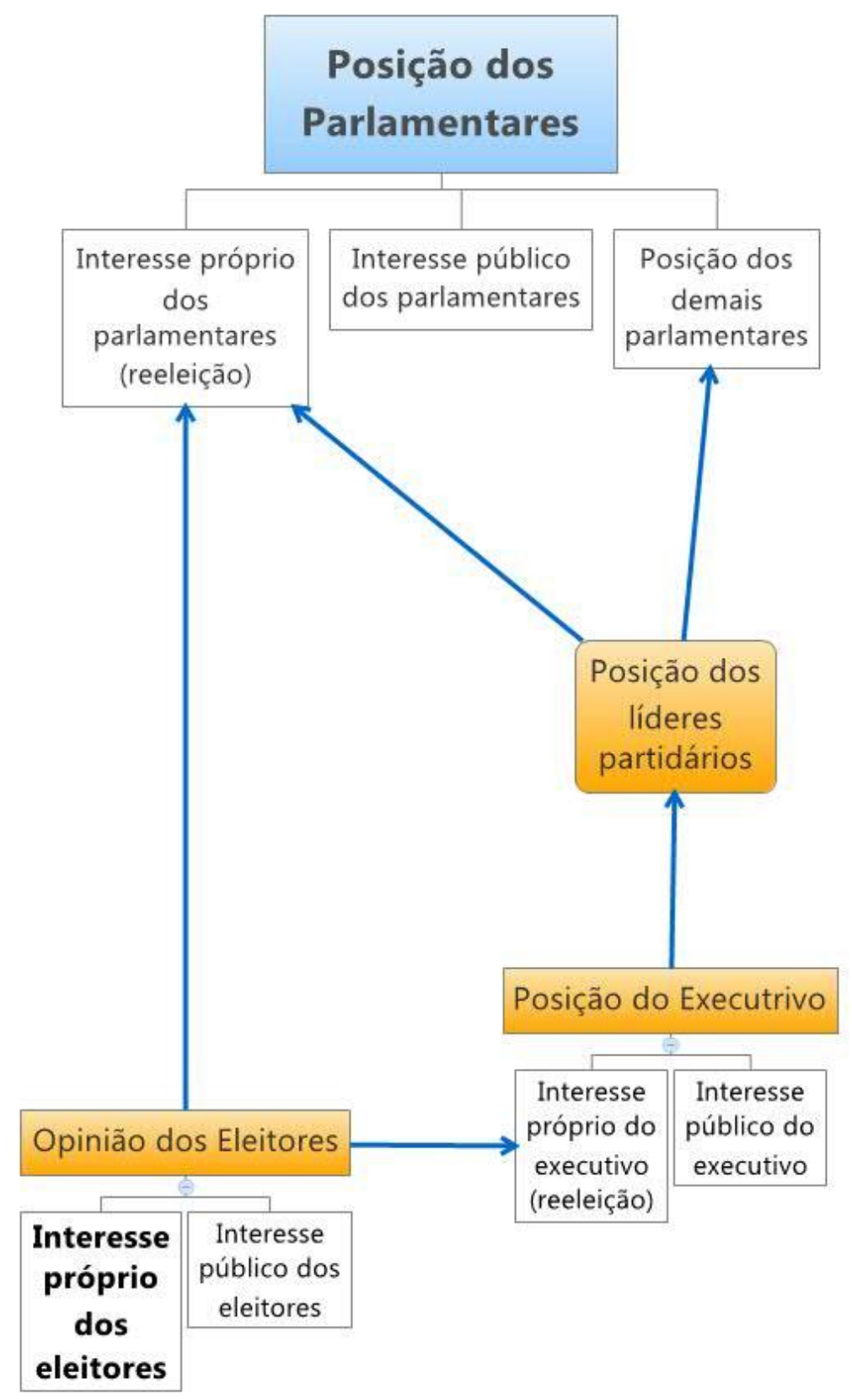

Tais questões serão extensamente discutidas no próximo capítulo. Por ora, iremos nos ater a somente um detalhe: os políticos não se engajam em todos os assuntos, já que isso levaria a uma baixíssima produtividade do parlamento. Afinal, se fosse assim, cada proposta legislativa teria de convencer todos os parlamentares. No Congresso real, os legisladores procuram atuar em assuntos que mais dominam ou que podem render melhores frutos eleitorais, delegando o restante ao partido e aos demais parlamentares. No mesmo sentido, seria um absurdo que os eleitores se engajassem em 
todos os assuntos, algo que nem os políticos profissionais fazem. Eles se engajam nos assuntos que mais os afetam diretamente, nos que acham que o governo pode influir e naqueles cujas causas e efeitos acreditam compreender.

Podemos assumir, portanto, que a maior parte dos parlamentares e eleitores assume uma posição indiferente sobre a maior parte das propostas do parlamento. Isso ajuda a explicar por que os problemas expostos acima não levam à constante paralisia do parlamento. Figueiredo \& Limongi (1999) e Figueiredo \& Limong (2004) mostraram que existe uma verdadeira divisão do trabalho dentro do Congresso. Bem considerado, o trabalho congressual é coletivo, o que "desobriga" o parlamentar individual a tomar posição em todos os assuntos.

Contudo, uma proposta com muitas clivagens atrai a atenção de muitos atores na sociedade e no parlamento, fazendo com que sejam reivindicados mais assentos nas mesas de negociação. Isso dificulta a formação de maiorias, além de aumentar a quantidade de concessões necessárias.

No caso da reforma tributária, a concessão para um setor obrigava o governo a dar concessões para outro. Por exemplo, para evitar perda de arrecadação dos estados e municípios, o governo aumentava alguns tributos, o que provoca o descontentamento do setor privado. O fim da guerra fiscal agradava aos estados industrializados, mas desagradava os estados pobres. O princípio do destino, ao contrário, agradava aos estados consumidores e desagradava aos estados produtores. Nesses casos, a concessão para um ator tende a gerar externalidades negativas para os demais atores, implicando necessidade de mais negociações em um looping infinito. Uma proposta impopular, como a criação de um imposto, pode ser barrada no parlamento simplesmente porque não tem maioria. Mas uma proposta com muitas clivagens pode converter maiorias em minorias.

Conclusão: o aumento de clivagens em uma reforma incentiva que mais atores busquem participar das negociações e torna a negociação mais complexa, pois as concessões para um ator entram em contradição com as concessões para os demais atores. 


\section{4 - Democracia: propostas e acordos}

O acordo de maioria é um imperativo de qualquer sistema que chamemos de democrático. Ele impõe alguns constrangimentos que não são muito evidentes à primeira vista. A maioria das pessoas não percebe o quão difícil é se chegar ao número mágico de $50 \%$ mais um. O mundo não é unidimensional. A maioria das questões admite mais do que duas alternativas factíveis. Assim, a agregação das preferências frequentemente não chega a uma situação de maioria. As instituições parlamentares preveem regras para restringir o número de opções e facilitar a formação de coalizões majoritárias, mas, como procuramos expor neste capítulo, isso está longe de ser uma arte fácil.

A reforma tributária, por ser um assunto complexo, esteve dominada pelo debate entre especialistas. Os profissionais da economia e do direito costumam ver o mundo a partir de modelos abstratos a partir dos quais se busca atingir uma situação ótima, ideal e justa. Diante de uma situação claramente ruim, como a apresentada no sistema tributário brasileiro, eles acabam por formular propostas de reestruturação global. Mas isso não é a melhor forma de se atingir acordos, pois dificulta a constituições de maiorias.

Os especialistas técnicos são extremamente avessos a reformas graduais, pois isso dificulta a constituição de um sistema coerente. No entanto o conhecimento técnico é insuficiente para promover reformas em situações democráticas. É preciso conhecer as tecnicalidades da política. Do contrário, o status quo vence. 


\section{4- Propostas políticas em perspectiva comparada.}

Este trabalho argumenta que as reformas tributárias adotadas pelos governos pós-1988 têm muitas clivagens, provocando um problema de multidimensionalidade. Porém, poder-se-ia argumentar que toda reforma provoca tensões, discussões e disputas, e que, portanto, as polêmicas da reforma tributária não a tornam singular. Em ciência é difícil determinar o que muito ou pouco. É preciso procurar algum referencial abstrato ou se comparar casos.

Neste trabalho iremos comparar casos. Argumentaremos que a estratégia política adotada pelos operadores políticos da questão tributária gerou mais clivagens do que as grandes reformas aprovadas pelo Executivo no período pós-1988.

\section{1 - Comparação entre propostas políticas: princípios teóricos}

Em meados do século XX, a ciência política americana defendia que $A$ análise [política] requeria simplesmente um inventário dos grupos participantes e suas estratégias, normalmente em forma cronológica [tradução nossa] (Lowi, 1964, p. 678). Era o auge do "pluralismo"; movimento teórico que defende que nas sociedades democráticas o poder está disperso e que, portanto, a luta entre grupos sociais, seus recursos de poder e suas estratégias políticas, ditava a ação do Estado. Contudo, tal perspectiva não explicou alguns fenômenos muito importantes, como, por exemplo, o fato de a maior parte dos representantes de grandes empresas americanas ser a favor do livre comércio (na proporção de 3 para 1, na medida mais conservadora) e o Congresso americano aprovar regularmente medidas protecionistas (Lowi, 1964, p. 684). Igualmente, a perspectiva pluralista não conseguia explicar por que os grupos políticos às vezes montam organizações estáveis e duradouras e, outras vezes, são grupos frágeis e efêmeros. Em verdade, o esquema pluralista não abria espaço para a sua contradição. Se uma proposta era aprovada, atribuía-se automaticamente ao seu grupo apoiador a causa de sua vitória, tivesse ele influído ou não na disputa. Inversamente, se uma proposta era rejeitada, atribuía-se o resultado à fraqueza de seus apoiadores ou à força 
de seus opositores. A estrutura estatal e os políticos profissionais eram vistos como atores passivos, ou, quando muito, como "mais um" dos jogadores. A proposta em disputa não cumpria nenhum papel nesse modelo teórico.

Sobre essas questões, se debruçou o seminal artigo American Business, Public Policy, Case-Studies and Political Theory de Theodore J. Lowi (1964), que provocou uma reviravolta na teoria das políticas públicas ao dizer que não só a política (politics) determinava a ação do Estado, como igualmente as políticas públicas (policies) determinavam a forma de atuação dos atores políticos. Diferentes áreas fazem com que os atores se organizem diferentemente.

A perspectiva de Lowi tem os seguintes pressupostos: (1) os atores estabelecem relações políticas de acordo com suas expectativas de ganhos e perdas (nas palavras de Robert Dahl, “o poder para quê? ${ }^{46 ") ; ~(2) ~ e m ~ p o l i ́ t i c a, ~ a s ~ e x p e c t a t i v a s ~ s a ̃ o ~ d i r e c i o n a d a s ~ a ̀ s ~}$ políticas governamentais, e, portanto, (3) as relações políticas são determinadas pelas qualidades das políticas públicas em questão. Em outras palavras, não é a disputa política que determina a política pública (politics make policies), mas de certa forma o contrário: as políticas públicas determinam a disputa política (policies make politics).

Lowi cria uma tipologia das arenas decisórias que se tornou clássica. Em sua visão existem três tipos de políticas: distributivas, regulatórias e redistributivas. As políticas distributivas são aquelas que podem ser propostas com poucos custos, pelo menos no curto prazo (Lowi, 1964:690). São exemplos deste tipo de política as emendas parlamentares, subsídios, protecionismo a setores da indústria e da agricultura e cargos púbicos para "patronagem". Esse tipo de política tende a produzir políticas de "não interferência mútua" e troca de favores (log-rolling). Os políticos cedem recursos distributivos em troca de apoio a propostas impopulares. Portanto, as políticas distributivas são usadas para congregar propostas com conteúdo totalmente díspar. Foi esse o caso das feministas e dos esportistas citado no capítulo anterior. Outro exemplo: nas três reformas tributárias analisadas, o governo cedeu para a bancada do Amazonas a prorrogação em dez anos da Zona Franca de Manaus. Nenhuma das reformas tinha esta proposta em sua formulação original, mas ela foi incluída para angariar apoio às propostas.

\footnotetext{
${ }^{46}$ Dahl (1967), capítulo 6. Apud Lowi (1964).
} 
O segundo tipo de política são as regulatórias. Elas podem ser tão individualizadas quanto as propostas distributivas, mas seu custo não é tão desprezível. Elas separam quem ganha e quem perde. Sua implementação normalmente se dá na lei geral, embora seu impacto possa ser localizado (Lowi, 1964, p. 691). Nesses casos, as associações políticas costumam ser temporárias e instáveis, pois quando os atores políticos defendem leis gerais, eles se agregam por grupos de compartilhamento de atitudes (shared atitudes) ou "relações tangenciais" (Lowi, 1964, p. 695). Se as políticas distributivas favorecem os acordos de cúpula, as políticas regulatórias favorecem o típico modelo pluralista onde há competição de múltiplos grupos.

Por último, há a arena redistributiva. Nela, a tensão política atinge seu ponto máximo. Os ganhos e as perdas são altos e claramente determinados. As categorias atingidas são amplas e se aproximam, direta ou indiretamente, das classes sociais (burguesia e proletariado; grandes e pequenas empresas; Estado e contribuintes; etc). Trata-se de políticas de alto conflito e que, por isso, levam os atores a construir organizações fortes, duradouras e centralizadas. Se as políticas distributivas favorecem o acordo de elites e as políticas regulatórias, o pluralismo de grupos, as políticas redistributivas favorecem o confronto de elites. A disputa se dá entre uma elite dominante e uma elite contra-hegemônica.

O argumento principal deste trabalho usa uma derivação desta concepção, pois tentaremos mostrar que o fracasso da reforma tributária (a disputa partidária) foi causado pelas qualidades das propostas do Executivo (a política pública). Porém, não usaremos exatamente a taxonomia de Lowi. Apesar de seus insights geniais, é muito difícil diferenciar uma arena de outra, sendo necessário fazer julgamentos subjetivos. Isso acontece porque as categorias de Lowi não estão ligadas a nenhuma teoria da ação social ou política, o que impede a generalização e aplicação dos argumentos para outros casos práticos além daqueles citados pelo autor.

Um segundo artigo, que oferece uma perspectiva superior sobre o tema, é Politics of Regulation de James Q. Wilson (1984 [1974]). Nesse artigo, o autor indagou por que as regulações econômicas são muitas vezes distintas daquelas recomendadas pelos economistas. Em suas palavras, os economistas e outras pessoas frequentemente queixam-se de que a regulação imposta aos negócios americanos são não ótimas ou até mesmo desnecessárias. Os livros e jornais acadêmicos estão cheios de análises detalhadas de por quê as políticas regulatórias estão erradas e como elas poderiam ser 
corrigidas" [tradução nossa] (Wilson, 1984, p. 89). Muitos defenderam que isso é fruto do amadorismo e populismo dos políticos, ou até mesmo da corrupção.

Essa opinião foi esboçada (em linguagem muito mais elegante) pelo artigo de George Stigler (1984) The Theory Economic of Regulation, no qual o autor argumenta que as agências reguladoras tendem a ser "capturadas" pelas empresas reguladas. Com isso surgem regulamentos cujo objetivo não é aumentar a eficiência econômica, mas proteger os lucros das empresas ${ }^{47}$. Esse é o caso dos regulamentos que criam barreiras à entrada aos mercados ou até mesmo patrocinam a formação de um cartel ou monopólio. Há inúmeros exemplos desses casos, como as licenças profissionais e concessões corporativas (taxi, advocacia, viagens rodoviárias, transporte aéreo, navegação). Os reguladores muitas vezes tomam medidas sabidamente ineficientes que são implementadas justamente porque são pouco custosas para as empresas (como mensagens de advertências nos maços de cigarro), sendo que medidas efetivas são descartadas. Em outros casos, as agências reduzem o rigor de fiscalização ou aprovação de produtos (como foi o caso da Comissão de Drogas e Alimentos - FDC, em inglês nos Estados Unidos até os anos de 1960).

Porém, essas falhas na ação Estatal não acontecem por decorrência da incompetência ou venalidade dos políticos e burocratas governamentais (pelo menos não em todos os casos). Existem imperativos políticos na regulação econômica. Esses imperativos são determinados pela natureza do mercado a ser regulado, o que, bem considerado, conduz a uma nova e mais sofisticada versão do insight de Lowi de que "policies make politics".

O esquema de Wilson manipula duas variáveis simples: os custos e os benefícios das políticas, cujo grau de impacto cria constrangimento à ação do Estado. O pressuposto é de que, quanto mais concentrados e delimitados os custos de uma proposta, maiores serão as chances de que os grupos perdedores se mobilizem contra a política. Por conseguinte, quanto mais concentrados forem os benefícios da proposta, maiores as chances de os ganhadores se mobilizarem. E inversamente, custos difusos e benefícios difusos tendem a não gerar mobilização. Assim, os reguladores têm grande dificuldade em promover reformas que ampliam uma pequena parcela de uma grande

\footnotetext{
${ }^{47}$ Categorias profissionais e burocracias podem ter uma atuação semelhante e também "capturar" os órgãos reguladores.
} 
quantidade de orçamentos. Prejudicar uma pequena parcela de uma grande quantidade de orçamentos é bem mais fácil.

Enfim, basicamente, o esquema cria quatro tipos de políticas:

\section{Tabela IX - Tipologia política de James Q. Wilson}

\section{Benefícios}

\begin{tabular}{lc|c|}
\multirow{2}{*}{ Custos } & \multicolumn{1}{c}{ Difusos } & \multicolumn{1}{c}{ Concentrados } \\
\cline { 2 - 4 } Difusos & Política Majoritária & Política Clientelista \\
\cline { 2 - 4 } Concentrados & $\begin{array}{c}\text { Política dos } \\
\text { Empreendedores }\end{array}$ & $\begin{array}{c}\text { Política dos Grupos de } \\
\text { Interesse }\end{array}$ \\
\hline
\end{tabular}

As políticas com custos difusos e benefícios concentrados (políticas clientelistas), são as mais fáceis de serem implementadas. Trata-se de um tipo de política muito parecido com o que Lowi chamou "políticas distributivas". Como os custos estão espalhados por um grande e indefinido grupo e os benefícios afetam um grupo pequeno e relativamente homogêneo, a tendência é a regulação ser facilmente implementada e dificilmente revertida. Existem muitos meios de se influenciar um governo, mas seu custo quase nunca é baixo. Poder-se-ia organizar protestos e greves; fazer propaganda negativa ou positiva dos parlamentares ou dirigentes executivos que são mais identificados por determinadas políticas; mobilizar eleitores ou doar recursos para as campanhas eleitorais. E mais importante de tudo: é preciso organizar parceiros com problemas parecidos para atuar de forma coletiva, pois assim se dilui o custo da ação política e se aumenta sua influência. Contudo, atuar coletivamente envolve um custo e, muitas vezes, um longo processo de organização e mobilização política. Caso o ganho individual seja pequeno, os agentes podem acreditar que o custo da ação é maior do que os benefícios gerados por ela.

Um caso claro é a distribuição de cargos públicos. Muitos cidadãos podem acreditar que o governo distribui cargos em demasia e que a atuação desses funcionários serve mais a interesses partidários do que ao bem-estar social. Porém, o custo por contribuinte de um cargo público é tão pequeno que não haveria ganho econômico individual em se mobilizar para suprimi-lo, nem que fosse necessário apenas pagar o custo de se dirigir até a sede do governo para protestar. Como consequência, o prejuízo 
econômico não leva à mobilização política, pois o custo da mobilização é maior do que o prejuízo causado.

Por outro lado, muitos grupos podem obter grandes rendas impondo custos a uma pluralidade de orçamentos individuais. Esse é o caso das políticas de licenças (como as usadas para taxistas e operadores de transporte interurbano), autorização para a comercialização de determinados produtos, proteções contra a concorrência estrangeira, subsídios etc. A atuação de tais setores tendem a assumir as seguintes características: (1) envolvem a redução da competição pelo preço no setor afetado, (2) visam a impor barreiras à entrada no mercado em questão, (3) os beneficiários da política irão influir fortemente na agência reguladora, (4) o setor e a agência reguladora irão preferir atuar de forma pouco visível, a fim de não atrair mobilização dos atores prejudicados (os contribuintes ou consumidores) e (5) apesar de a regulação ser polêmica, ela será defendida através das supostas vantagens de se ter menor competição, como a maior segurança dos produtos, o fim das fraudes, o desenvolvimento do setor afetado etc (Wilson, 1984, p. 87).

Isso é possível por que um grupo pequeno pode se mobilizar mais facilmente do que um grupo grande. Um grupo pequeno tem integrantes com interesses mais homogêneos, favorecendo o surgimento de um sentimento de identidade coletiva. Em grupos pequenos, a ação de cada indivíduo é claramente percebida pelos demais e imediatamente recompensada pelo reconhecimento. Já em grandes grupos, não há identidade e confiança coletiva forte, fazendo com que as pessoas não se mobilizem acreditando que as demais não irão se mobilizar também. Como consequência, se favorece o conformismo e a passividade (Wilson, 1984, p. 86).

A vantagem desta abordagem é que ela não apenas descreve o que Lowi chamou de "política distributiva", como também a explica através de uma teoria racional geral da ação política: é vantajoso mobilizar-se quando os benefícios da mobilização são maiores do que seus custos.

O segundo tipo de política da tipologia de Wilson tem custos concentrados e benefícios concentrados (política de grupos de interesses). Existe uma clara analogia à "política redistributiva" de Lowi, pois os ganhadores e perdedores são claros. Nessa política, ambos os lados da questão têm interesse em se mobilizar. Há, consequentemente, intensa competição política. São exemplos deste tipo de política os conflitos entre empregadores e trabalhadores ou - na reforma tributária brasileira - entre 
estados exportadores líquidos e importadores líquidos. As características desse tipo de política são: (1) nenhum ator conseguirá dominar permanentemente a agência que regulamenta o mercado (2) haverá uma contínua disputa e negociação para a mudança do status quo e (3) o conflito dará grande visibilidade à política, pois os competidores terão incentivos para buscar apoiadores em outros setores e denunciar as estratégias do oponente (Wilson, 1984, p. 87).

O terceiro tipo de política analisado por Wilson tem custos concentrados $e$ benefícios difusos (política dos empreendedores). Essa modalidade de política não tem analogia com nenhuma das categorias de Lowi. São esses os casos em que os opositores da política têm interesse em se mobilizar, mas seus defensores são fracos e vacilantes. Existe um elemento tipicamente comportamental que agrava esse fato: as pessoas valoram diferentemente os ganhos e as perdas. Ao que tudo indica, os eleitores parecem dar mais importância à perda do que ao ganho de bem-estar. Existe mais mobilização para evitar a perda de 100 do que para obter um aumento de 100. Isso torna particularmente difícil retirar privilégios de setores e grupos, pois eles irão se mobilizar com uma força muito maior do que os que potencialmente ganhariam (Arnold, 1990, pp. 32-33), (Pierson, 1996, p. 146).

Infelizmente, esse é o tipo mais comum de reforma defendida pelos economistas e especialistas em políticas públicas. São exemplos desses casos as políticas de preservação ambiental, os direitos dos consumidores e aquelas reformas que afetam interesses claros e imediatos e buscam apenas "uma melhor eficiência do sistema econômico".

As "políticas dos empreendedores" são as mais difíceis de serem aprovadas. Normalmente seguem "janelas de oportunidades" como crises e escândalos. No contexto americano, Wilson destaca a importância de parlamentares líderes de coalizão. Esses políticos servem-se dessas propostas como forma de atrair visibilidade midiática e o eleitor de longo prazo. Ao contrário do contexto brasileiro, os presidentes americanos mostram um crônico desinteresse por reformas desse tipo, pois elas não convencem a maioria. Elas são levadas por aqueles que não estão interessados em políticas para a maioria, mas em nichos estáveis do eleitorado. Apesar de estar se dirigindo a grupos "duros de se alcançar" (hard-to-reach) os empreendedores podem conseguir o apoio de associações, jornalistas e intelectuais com o ativismo na questão (Wilson, 1984, p. 89). 
As características desse tipo de política são: (1) no início os empreendedores políticos concentram publicidade no "mal" que representa o setor ou indústria que ganha com o status quo. Isso é necessário para poder se criar alguma condição de competitividade política, bem como visibilidade e atenção do congresso para a questão. (2) A forma original da reforma é "radical”, pois há pouco incentivo para acomodações e concessões para os perdedores (acordos e compromissos diminuem a capacidade de os propositores mobilizarem apoio com base em apelos moralistas). (3) Uma vez iniciado o processo político, muitas negociações e concessões terão de ser feitas para que se obtenha viabilidade política e administrativa à proposta. (4) A formatação final será fortemente marcada pelo processo político (e não apenas pelo aspecto técnico). Em verdade, as reformulações da proposta original costumam ser tão grandes e complexas que o resultado final dessas políticas é um problema de análise por si só (Wilson, 1984, p. 89).

Como mostraremos adiante, essa descrição cabe bem à maioria das propostas da reforma tributária.

Por fim, existem propostas com custos difusos e benefícios difusos (políticas majoritárias). Nesse tipo de política, nem os perdedores nem os ganhadores têm fortes interesses em se mobilizar. Assim, podemos dizer que ela é análoga à política regulatória de Theodore Lowi. Como os parlamentares não são pressionados por seus eleitores (vale dizer, não precisam se preocupar com os efeitos da política na sua reeleição) o peso dos técnicos e das opiniões públicas dos parlamentares tem uma maior relevância na decisão final. Nesse caso, os parlamentares serão guiados pelos grupos pluralistas de opinião, congregados pelas shared attitudes ou "relações tangenciais".

O esquema montado por Wilson é muito elegante e sofisticado, além de parecer aplicar-se bem à análise das reformas constitucionais brasileiras. Isso se deve ao fato de sua lógica da mobilização ser adequada à teoria da escolha racional (é vantajoso mobilizar quando os benefícios da mobilização são maiores do que seus custos). Custos e benefícios são variáveis mensuráveis, tanto para os analistas quanto para os atores sociais. Isto contrasta com o modelo de Lowi, onde a diferenciação dos tipos de política depende de julgamentos subjetivos.

Contudo, é preciso fazer uma ponderação sobre o modelo de Wilson. Ele é bom para mostrar por que reformas ineficientes acontecem (é difícil exagerar a importância 
desse achado), mas é necessário adaptá-lo para explicar por que uma reforma é aprovada e outra não.

Wilson mostra que é factível que uma reforma com custos maiores do que os benefícios seja aprovada. Para isso, basta que os custos sejam suficientemente divididos - provocando um baixo prejuízo per capita - e os benefícios sejam suficientemente concentrados - resultando em alto ganho per capita. Porém, seguindo o mesmo raciocínio, é perfeitamente possível pensar que uma reforma com custos difusos e benefícios concentrados seja rejeitada; desde que os custos sejam suficientemente dramáticos para os perdedores e os ganhos suficientemente insignificantes para os ganhadores. Por exemplo: uma fábrica poluidora que tenta se instalar perto de um bairro residencial ou próximo a um rio que serve para a irrigação. Apesar de as perdas serem difusas, se elas forem suficientemente grandes (per capita) a comunidade local terá incentivos para se mobilizar. Por outro lado, caso a fábrica tenha outra alternativa além daquele terreno, ela poderá aceitar a perda (concentrada) e mudar de lugar. Em sentido semelhante, uma proposta com ganhos difusos e perdas concentradas pode ser aprovada, apesar da oposição dos perdedores. Isso pode acontecer desde que os ganhos esperados sejam suficientemente grandes.

Em 2009 houve uma discussão sobre como seriam distribuídos os royalties do petróleo retirado na camada "pré-sal", no litoral sudeste brasileiro. O mecanismo vigente favorecia os estados de localização das plataformas continentais da camada présal (Rio de Janeiro, São Paulo e Espírito Santo). Porém, os demais estados se mobilizaram para que os recursos do petróleo fossem distribuídos igualmente entre todos os 27 estados brasileiros. No Rio de Janeiro houve manifestações de rua, com a participação de milhares de pessoas, incluindo artistas de renome nacional. $\mathrm{O}$ governador Sergio Cabral chegou a chorar diante das câmeras de TV contra o "crime" que estava sendo cometido contra o Rio de Janeiro. Contudo, a reforma foi aprovada pelo Senado Federal. O pré-sal renderá muito dinheiro, e mesmo com os recursos divididos por 27 partes, os estados acreditaram que era compensador se mobilizar por ele.

Assim, podemos concluir que, apesar de a distribuição ser importante, o montante per capita dos custos e benefícios é mais importante. 
Uma última contribuição que usaremos aqui para a teoria da análise dos conteúdos políticos é o livro Logic of Congressional Action de R. Douglas Arnold (1990). Ele também criou uma tipologia política das políticas. Em seus termos, podemos classificar as políticas segundo efeitos geograficamente determinados, setorialmente determinados e efeitos gerais (Arnold, 1990, pp. 25-28). Essa tipologia não parece evoluir muito em relação à tipologia de Wilson. Além disso, ela está assentada sobre uma diferenciação que parece ser mais importante no contexto americano, onde os parlamentares são muito sensíveis a custos geograficamente concentrados, pois sua eleição é distrital. Em sentido semelhante, o parlamentar membro das comissões parlamentares americanas tende a ser muito sensível a lobbies setoriais, pois tais comissões são o locus por onde os setores barram propostas que lhes são desfavoráveis. No Brasil, os distritos eleitorais são grandes, com muitos candidatos, e as comissões, fracas, já que são dominadas pelos líderes partidários e podem ser contornadas com os pedidos de urgência (Limongi \& Figueiredo, 2004). Portanto, no nosso caso, não há diferenças claras entre as políticas com custos geográficos e as com custos setoriais, pois tanto um caso como o outro atuam em todas as fases do processo Legislativo.

Muito mais interessantes são as considerações de Arnold sobre a teoria da ação parlamentar. As contribuições de Lowi, Wilson e tantos outros fizeram com que se tornasse relativamente fácil para os cientistas políticos explicar por que os parlamentares aprovam propostas com benefícios relativamente localizados e custos relativamente dispersos. Mas como explicar o contrário? Por que os parlamentares muitas vezes aprovam propostas com benefícios dispersos e custos concentrados? Ou então, por que os parlamentares aprovam um determinado benefício a um grupo específico e depois o retiram?

Arnold tenta responder essas questões aprimorando a teoria da ação parlamentar. Segundo sua visão, os parlamentares podem ser divididos entre os parlamentares ordinários e os parlamentares líderes de coalizão. Os líderes de coalizão são políticos empreendedores que buscam desenhar estratégias para influenciar os demais parlamentares a aprovar sua proposta. Segundo dispõe o autor, podemos ainda considerar que o principal interesse de todos os legisladores é garantir a sua reeleição (Arnold, 1990, pp. 5-8). Obviamente não se está dizendo que o único interesse dos parlamentares é se manter no poder, mas os parlamentares precisam continuar no jogo 
para que suas ações tenham algum peso na decisão política do governo. Mesmo os empreendedores políticos dedicam apenas seu tempo "livre" à militância em causas políticas (Arnold, 1990, pp. 7-8). Vale dizer, primeiro eles se dedicam a agradar seus apoiadores - inclusive utilizando-se de benefícios concentrados -, para depois se dedicarem a causas mais gerais.

Também pode-se considerar que, quando não há uma séria ameaça eleitoral, os parlamentares podem decidir seus votos com base em outros critérios que não a reeleição. Esses critérios podem ser a lealdade partidária, retribuição por um favor passado, obtenção de créditos futuros, ideologia, opinião de especialistas, etc. Em resumo, sob as circunstâncias corretas, os parlamentares podem preferir o bem geral ao benefício de setores localizados, sendo que a busca pela reeleição encoraja o particularismo. Nas situações em que os parlamentares se veem "livres" dessa pressão, eles são suscetíveis à influencia dos empreendedores. Isso pode acontecer nas situações onde (1) os custos não são claros, (2) existe formas de apagar os rastros entre uma medida impopular e o voto do parlamentar ${ }^{48}$ ou (3) outro ator (presidente ou relator), absorve os custos políticos da proposta. Os empreendedores procuram antecipar as situações onde os parlamentares podem ver-se livres da ameaça de retribuição eleitoral e desenhar tanto as políticas quanto a tramitação da política para poder convencer os parlamentares a aprovar as reformas impopulares.

Igualmente importante é o aspecto da teoria de Arnold que demonstra a influência da complexidade técnica da proposta em suas chances de aprovação. Segundo o autor, podemos considerar que, diante das políticas públicas, existem três tipos de pessoas: especialistas, cidadãos e generalistas (Arnold, 1990, pp. 17-36). Os especialistas são aqueles que se debruçam sobre a questão com afinco a fim de conhecêla em detalhes. Esse é o caso dos cientistas naturais e sociais. Eles observam em detalhes apenas um pequeno nicho do conhecimento. Eles tendem a argumentar que não

\footnotetext{
${ }^{48}$ Esse é o ponto principal do livro de Arnold. Ele mostra, por exemplo, que as reuniões fechadas e as decisões delegadas aos chefes das comissões foram fundamentais para a aprovação da reforma tributária americana de 1986. Como os grupos sociais não puderam rastrear a participação exata de cada parlamentar na aprovação das propostas, os parlamentarem puderam sair das reuniões e falar aos lobistas "eu tentei, fiz de tudo, mas Packwood [o relator da reforma] não deixou. Foi horrível" (Arnold: 222). No nosso caso isso não parece ser um fator tão fundamental, pois todas as votações das reformas constitucionais são nominais. Por outro lado, podemos argumentar que no Brasil os parlamentares estão mais blindados contra a pressão de grupos setoriais ou regionais. Os mandatos também são mais longos (nos EUA, os deputados têm mandatos de dois anos e os senadores, de anos, sendo que no Brasil seu mandato corresponde exatamente ao dobro). A força legislativa do Presidente brasileiro, além disso, é muito maior, criando incentivos de modo a que os parlamentares resistam à pressão de grupos para seguir a orientação do governo.
} 
existe solução simples, que mesmo a mais inequívoca solução apresenta efeitos colaterais e que muitos subterfúgios que parecem resolver o problema apenas o pioram. Já os cidadãos formam sua opinião sobre as políticas muito superficialmente. Eles comparam as decisões do governo com seu mundo próximo, com sua experiência passada e com as informações obtidas pela mídia. Às vezes eles são instruídos pelas opiniões dos especialistas, como quando os médicos falam que fumar faz mal à saúde. Porém, muitas vezes tais instruções são ignoradas por serem complexas demais ou contraintuitivas demais. Arnold argumenta que não se sabe bem por que os cidadãos acreditam que a pena de morte tem algum efeito sobre a criminalidade, ou por que acreditam que o governo deve se esforçar para manter um orçamento equilibrado. $\mathrm{O}$ fato é que essa é que estas são as mais estáveis preferências da opinião pública americana (Arnold, 1990, p. 22).

Os generalistas são pessoas que discutem as políticas profissionalmente, mas não são tão focados quanto os especialistas. Parlamentares, lobistas, jornalistas, colunistas e burocratas são generalistas. Eles frequentemente obtêm sua opinião de instruções com os especialistas. Eles leem livros, participam de cursos, palestras e seminários. Contudo, muitas vezes eles ignoram a opinião dos especialistas para aderir à opinião dos cidadãos. Isso acontece por desinformação ou então devido à necessidade de se obter popularidade e apoio junto à população. O que ajuda a explicar as observações de Wilson com respeito à incongruência entre a opinião dos economistas e a ação dos políticos.

Os especialistas e os cidadãos enxergam diferentemente a relação entre as causas e os efeitos (Arnold, 1990, pp. 18-25). Os especialistas propõem soluções sofisticadas, enquanto os cidadãos preferem soluções simples e imediatas. Por exemplo, muitos acreditam que o desempenho econômico do país está fraco em função da má qualidade do ensino. Uma forma de resolver o problema é ampliar a ajuda federal para os orçamentos dos governos locais destinados à educação. Com isso haveria mais dinheiro para aumentar os salários dos professores, e então profissionais mais qualificados seriam atraídos, gerando uma melhor qualidade do ensino. A melhoria do ensino conduziria à formação de trabalhadores mais produtivos e estimularia a otimização do desempenho econômico. Repare que a solução proposta possui muitas relações de causa e efeito. Supõe-se que uma maior ajuda federal levaria a um aumento do orçamento subnacional em educação, uma relação de primeira ordem. Também se acredita que um 
maior orçamento em educação leva a um maior salário dos professores. uma relação de segunda ordem. A melhoria do desempenho econômico, por sua vez, é uma relação de sexta ordem. Os cidadãos preferem, entretanto, políticas que tenham uma corrente causal mais curta, de preferência limitando-se a um único estágio. Por isso, muitos preferem que o problema da criminalidade seja resolvido com medidas de repressão ao invés de políticas sociais, educacionais ou judiciais. Ou então que o combate à inflação seja feito através de controles de preços e salários, mesmo que os economistas afirmem que essa é a pior solução.

Um segundo motivo para o ceticismo dos cidadãos e dos generalistas com as políticas mais complexas é a incerteza (Arnold, 1990, pp. 18-25). Os primeiros estágios da política são mais seguros que os estágios posteriores. A relação entre aumento dos orçamentos subnacionais em educação e o aumento dos salários dos professores é mais certa do que a relação entre gasto federal e aumento da produtividade. Caso pensemos que um estágio anterior tenha uma probabilidade de $80 \%$ de causar o estágio posterior, haverá apenas que $26 \%$ de chance de o primeiro estágio da política causar o sexto.

Esses achados são importantes porque vão ao encontro da afirmação básica deste trabalho de que políticas mais complexas são mais difíceis de serem defendidas. Uma relação complexa entre causa e efeito dificulta a obtenção de apoio, pois os benefícios se tornam menos perceptíveis. É o que se passa principalmente com os ganhos difusos, pois os lobbies setoriais estão melhor equipados do que os cidadãos para perceber ganhos e perdas em relações complexas.

Assim, observa-se que a complexidade tende aumentar o custo de se aprovar aquelas propostas que Wilson chamou de "política dos empreendedores". Em propostas sofisticadas, os cidadãos não conseguem relacionar as medidas sugeridas e seu bemestar. Por outro lado, os grupos que terão perdas concentradas não têm o mesmo problema, fazendo com que eles atuem para barrar a reforma.

\subsection{1- A Perspectiva adotada neste trabalho}

Vimos na seção anterior que, segundo Theodore Lowi, o conteúdo das políticas tem capacidade de influir na constituição das coalizões políticas. Portanto, podemos saber muito sobre a movimentação política de uma proposta apenas vislumbrando seu 
conteúdo. A análise dos ganhos e das perdas nos fornece informações extremamente úteis sobre como os atores deveriam racionalmente se comportar. Apesar de ser um argumento de caráter indutivo (pois as premissas não garantem a conclusão), ele nos ajuda a conhecer a movimentação política da reforma, uma vez que a influência real dos atores sobre as políticas públicas é uma informação extremamente difícil de se obter ${ }^{49}$.

Segundo James Q. Wilson, as características mais importantes de uma proposta são seus custos e benefícios - ou melhor, seus ganhadores e seus perdedores. É de se esperar que os ganhadores tentarão influir para a aprovação da proposta e os perdedores tentarão impedir a aprovação da proposta. Não é só o montante dos custos e benefícios que importa, mas também sua distribuição. Quanto mais concentrados os custos e benefícios, maior tende a ser seu valor per capita e mais intensa tende a ser a mobilização. Inversamente, quanto mais dispersa for a distribuição, menor tende a ser o montante per capita dos custos e benefícios e menor tende a ser a mobilização gerada.

Arnold, por outro lado, mostrou que o que importa não são apenas os custos e benefícios, mas também a ligação entre a política e a ação dos parlamentares, bem como a ligação da política com seus efeitos. Segundo ele, quando os parlamentares não têm sua reeleição ameaçada pela proposta, eles podem votar segundo outros critérios que não a aversão a custos concentrados e a preferência por benefícios concentrados, o que cria janelas de oportunidade para a aprovação de propostas com beneficiários amplos.

Seguindo os argumentos acima, tentaremos, no nosso caso, mostrar quais foram os ganhadores e os perdedores das propostas. A partir disso, faremos inferências sobre as clivagens políticas. Infelizmente temos poucos instrumentos para determinar tanto a quantidade quanto a distribuição dos ganhos e das perdas. Tentaremos, assim, simplesmente mostrar sobre quem recaem os custos e os benefícios. Seguiremos a ideia de Arnold, mostrando que as reformas bem sucedidas são aquelas que evitam a "revanche eleitoral" (electoral retribution).

A reforma ideal é aquela em que não há perdedores claramente delimitados. Quanto menos perdedores visíveis a proposta tiver, mais fácil será sua aprovação. De certa forma, os custos são mais importantes do que os benefícios, pois existe uma assimetria entre ganhos e perdas. Nesse sentido, argumentaremos que, de certa forma, o que o sucesso ou o fracasso das reformas está mais ligado ao número de opositores do

\footnotetext{
${ }^{49}$ Uma análise sobre as dificuldades de se encontrar relações causais entre a influência de grupos e os resultados de políticas pode ser encontrada em (Mancuso, 2007, pp. 121 - 137)
} 
que a seu peso. Ou pelo menos tanto o número quanto o peso. Os parlamentares brasileiros podem desagradar um ator social, inclusive lhe impondo custos concentrados. O apoio do Executivo, neste caso, mais do que compensa este inconveniente. O Executivo brasileiro controla o orçamento, os cargos públicos e a agenda legislativa. Ele tem poder para atrair os líderes partidários, que por sua vez atraem o apoio dos parlamentares. Como expusemos no capítulo 2, as minorias não têm muito peso no sistema brasileiro, pelo menos não até, agregadas, formarem uma maioria. A bem dizer, pouquíssimos setores sociais podem se constituir como atores de veto ao Executivo. Porém, desagradar a muitos setores é arriscado, pois se pode criar uma coalizão contra a proposta. A multidimensionalidade da reforma tributária gerou uma coalizão desse tipo, de modo que uma série de atores com perdas concentradas se mobilizou para barrar a proposta.

Abaixo mostraremos também porque isso não aconteceu em outras reformas. Apesar de a reforma do Judiciário e a reforma administrativa terem muitas e complexas propostas, elas focaram as perdas em um único setor cada uma: a reforma do Judiciário focou as perdas nos tribunais inferiores e a reforma administrativa nos servidores.

\subsection{2- Escolhas dos Casos}

A reforma tributária pode ser considerada uma reforma complexa, em primeiro lugar, em função de seu tamanho. Podemos pensar em três medidas de tamanho para uma reforma: (1) seu número de palavras, (2) o número de artigos alterados e (3) o número de itens alterados (capute, parágrafos, incisos e alíneas) ${ }^{50}$. Podemos comparar a reforma tributária com as emendas aprovadas de 1992 a 2008 pelas tabelas X e X.

\footnotetext{
${ }^{50}$ Foi excluída as frases puramente formais das emendas, como as famosas frases: As Mesas da Câmara dos Deputados e do Senado Federal, nos termos do $\$ 3^{\circ}$ do art. 60... ou Esta emenda entra em vigor na data de sua publicação. As datas e a composição das mesas das casas legislativas também foram retirados. Contudo, prazos para a entrada em vigor das medidas (quando não eram na data da publicação) foram mantidos, bem como condições impostas ao executivo ou ao congresso (regulamentação). No caso específico da PEC 233/2008, as condições e procedimentos representam quase metade do número de palavras da proposta. Trat-se de um subproduto da estratégia de "emenda autorregulável" ou "emenda sem regulamentos" da proposta. Isso foi feito porque os operadores da proposta queriam diminuir a insegurança dos agentes quanto aos passos futuros da proposta (Fonte: Bernard Appy, seminário no Cebrap, 25/04/2008).
} 
Como se pode observar, as propostas de reforma tributária são muito grandes quando comparadas às demais emendas constitucionais aprovadas. Isto pode ficar mais claro nos gráficos 4 e 5 , bem como na tabela $\mathrm{X}$ :
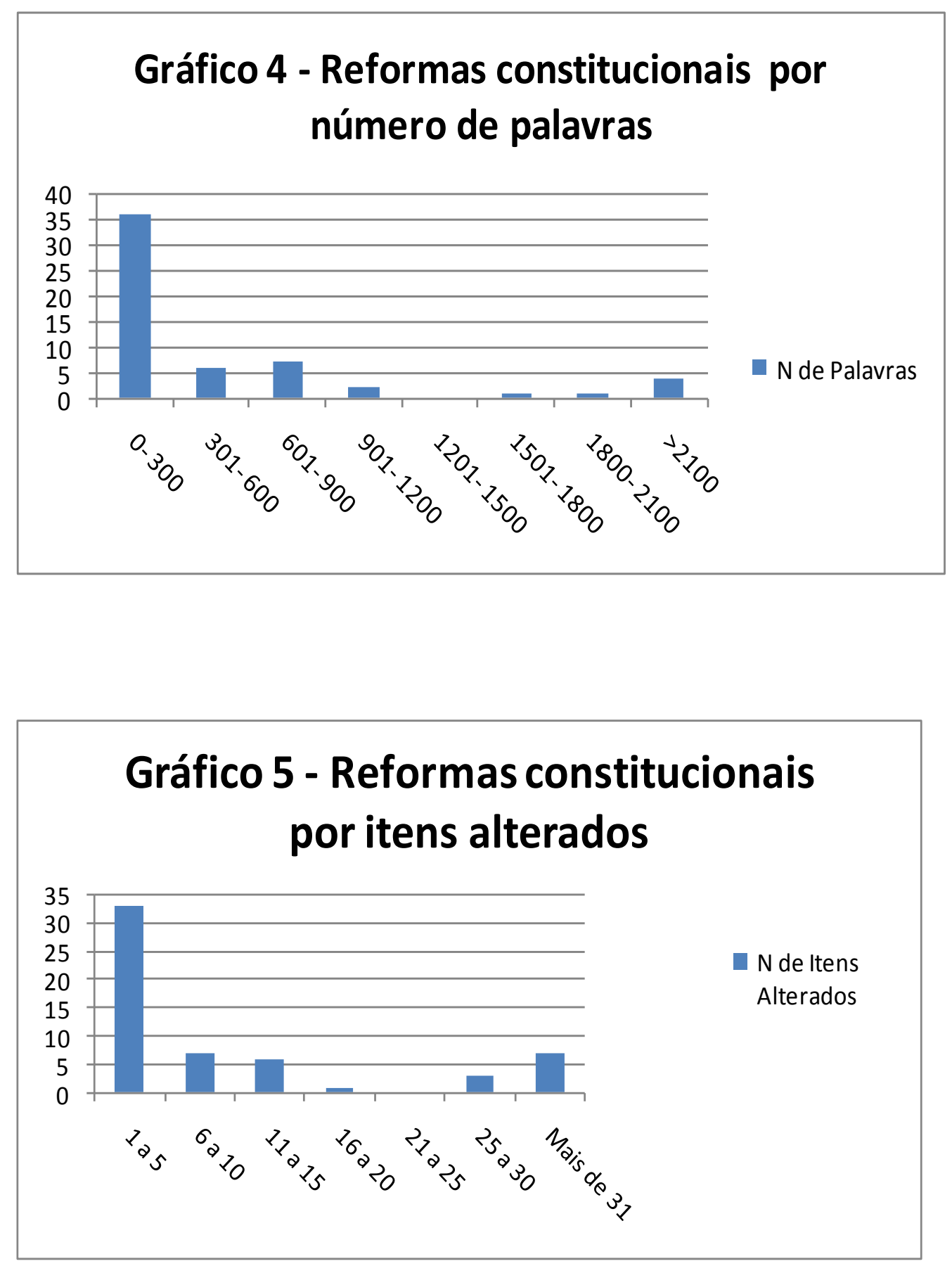

Fonte: elaboração própria, a partir do Câmara dos Deputados: www.camara.gov.br 


\begin{tabular}{|l|c|c|c|}
\hline \multicolumn{4}{|c|}{ Tabela X - Tamanho das Reformas Tributárias } \\
\hline \multicolumn{1}{|c|}{ PEC } & Número de Palavras & Artigos & Itens \\
\hline PEC 175/95 (original) & 3798 & 15 & 114 \\
\hline PEC 175/95 (relator) & 5505 & 34 & 182 \\
\hline PEC 41/03 (original) & 2198 & 13 & 62 \\
\hline PEC 41/03 (relator) & 4815 & 32 & 128 \\
\hline PEC 233/08 (original) & 5652 & 23 & 204 \\
\hline PEC 233/08 (relator) & 11840 & 32 & 344 \\
\hline Média & 5634,67 & 24,83 & 172,33 \\
\hline
\end{tabular}

A média de palavras das emendas constitucionais é de 592,77. Das 57 reformas constitucionais aprovadas de 1991 a 2008, trinta e seis $(63,15 \%)$ possuem até 300 palavras. Cerca de $20 \%$ das PECs alteram apenas um item da Constituição, 57,9\% alteram até cinco itens. Apenas sete emendas alteram mais de trinta itens da Constituição. A média das alterações propostas nas reformas tributária são mais 170,4!

Existem algumas reformas que são outliners. A maior emenda já aprovada pelo governo até o momento é a PEC 45/2004, a "reforma do Judiciário". A segunda maior reforma do país foi a EC 20/1998, a "reforma da previdência" do governo Fernando Henrique Cardoso. Essa proposta foi palco de intensa disputa política, resultando, inclusive, na derrota de muitos pontos do governo. De certa forma, ela só foi bem sucedida porque o governo resolveu usar a estratégia de reduzir as clivagens em disputa, reformando apenas a previdência do setor privado e deixando de conflitar com o sindicalismo do setor público. A reforma da previdência dos funcionários públicos só ocorreu com a EC 41/2003, a chamada "reforma da previdência" do governo Lula, que é a quarta maior emenda aprovada no período analisado. A estratégia de reduzir o número de atores com custos concentrados se mostrou eficaz para aprovar essas difíceis reformas.

Já a terceira maior reforma aprovada no período é a EC 19/1998, a "reforma administrativa" ou "reforma Bresser". É muito provável que ela tenha sido mais complicada do que a reforma da reforma da previdência, pois apesar de ter menos palavras, ela altera mais pontos da Constituição. Ela envolvia discussões jurídicas, administrativas, ideológicas, sindicais, etc. As outras duas reformas que têm mais de 1500 palavras são a $E C 42 / 2003$, que foi fruto da discussão da $P E C 41 / 2003$, e a $E C$ 53/2006, que criava o FUNDEB. 
Escolhemos as reformas do Judiciário e administrativa para comparar com a reforma tributária, pois elas são as que mais alteram pontos na Constituição. Isso as torna, a princípio, mais suscetíveis ao problema da multidimensionalidade. Consideraremos que as reformas da previdência claramente possuem uma clivagem única: ou se está a favor dos benefícios dos aposentados, ou se está a favor dos orçamentos públicos.

\section{2 - Reforma do Judiciário}

A reforma do Judiciário (PEC 96/1992; EC 45/2004) é a reforma que mais alterou pontos da Constituição Brasileira. Ela alterou nada menos do que 29 artigos da constituição e 146 itens. No total, a Emenda 45 tem 4646 palavras. Sua tramitação foi longuíssima, sendo um exemplo de construção gradual. O projeto mais antigo, no qual os demais foram apensados, é a PEC 96 de 1992, de autoria do deputado Hélio Bicudo. Em sua versão original, ela era uma reforma relativamente sucinta, com cerca de 1335 palavras. A proposta foi transformada em emenda de revisão em 1993. Chegou a ser arquivada, face aos encerramentos dos trabalhos da revisão constitucional. Em 1995, foi reaberta e apensada à proposta 112/1995 (de autoria do deputado José Genoino, que cria o "controle externo" do Judiciário). Apesar do relatório favorável do deputado Jairo Carneiro (em outubro de 1996), a comissão especial da Câmara dos Deputados nunca chegou a aprovar a proposta e ela foi novamente arquivada. Em fevereiro de 1999, a proposta é desarquivada e recebe um apoio revigorado do governo ${ }^{51}$. Em abril, é indicado um novo relator: o deputado Aloysio Nunes, eminente membro da base governista. Em junho, o relator apresenta seu parecer, mas este não é bem recebido pelos parlamentares e a relatoria é redistribuída à deputada Zulaiê Cobra (que é juíza). Em outubro de 1999, a relatora finalmente consegue o consenso necessário e aprova a proposta na comissão especial, por unanimidade. A esta altura, a proposta foi apensada às PECs 127/1995, 215/1995, 368/1996 e 500/1997. Ao contrário da regra geral do funcionamento congressual brasileiro, onde predomina o ativismo legislativo do

\footnotetext{
${ }^{51}$ Provavelmente isto se deve à CPI do Judiciário, que se seguiu às fraudes descobertas na construção do prédio do TRT de São Paulo. Ver em http://pt.wikipedia.org/wiki/Nicolau_dos_Santos_Neto http://pt.wikipedia.org/wiki/CPI_do_Judiciário
} 
Executivo, só há uma $P E C$ do Executivo Federal neste conjunto - e ela trata de um tema relativamente marginal (a 368/1996, que federaliza os crimes contra os direitos humanos). A versão aprovada na comissão especial tem nada menos do que 7909 palavras, altera 38 artigos da constituição e 204 itens. Durante nove meses, ela foi discutida em cerca de 36 sessões do plenário da Câmara dos Deputados, sendo finalmente remetida ao Senado Federal em 7 de junho de 2000. O projeto encolheu um pouco. Ele tinha 7118 palavras, alterava 32 artigos da Constituição e 192 itens. Lembrando que a média das emendas constitucionais não chega a seiscentas palavras.

No Senado, a proposta continuou sua tramitação gradual. A matéria teve um número incomum de emendas apresentadas. A polêmica das propostas modificativas foi tão grande que o relator, senador Bernardo Cabral, foi obrigado a aprovar seu parecer em muitas sessões, construindo gradualmente seu substitutivo. Houve seis votações do relatório. O relatório final só foi aprovado em novembro de 2002, impossibilitando sua tramitação em plenário devido à proximidade do fim da legislatura.

O governo Lula tinha a reforma do Judiciário como uma de suas metas. O ministro da Justiça, Márcio Thomas Bastos, criou uma secretaria exclusiva para tratar deste assunto (a Secretaria da Reforma do Judiciário, comandada pelo advogado Sérgio Renault). Porém, o governo não fez como na reforma tributária, onde se iniciou uma proposta inteiramente nova (duas vezes). Ele apenas retornou a proposta à Comissão de Constituição, Justiça e Cidadania do Senado, sob nova relatoria do Senador José Jorge. Após mais dois anos de tramitação no Senado, a reforma foi aprovada e publicada em 30 de dezembro de 2004, totalizando mais de doze anos de tramitação.

Apensar de ser a maior emenda que a constituição já sofreu, ela foi muito enxugada pelos Senadores. Saiu das 7118 palavras que foram aprovadas na Câmara dos Deputados para 4646 palavras. Isso aconteceu porque os Senadores retiraram alguns nós críticos da reforma, como o fim do nepotismo no Judiciário, a súmula impeditiva de recurso, exigência de três anos no cargo para vitaliciamento do juiz, alterações no Superior Tribunal Militar, etc. Estas propostas foram transformadas em uma nova emenda (PEC 358/2005), que até o momento não foi aprovada pela Câmara dos Deputados.

Mas o que propõe a reforma? Seu sentido geral é de regular o trabalho dos juízes de primeira instância e dos tribunais de justiça, seja aumentando o poder dos tribunais superiores (notadamente o Supremo Tribunal Federal), seja criando regras para o 
funcionamento dos tribunais inferiores. Provavelmente a maior inovação da reforma seja a criação de um órgão para fazer o controle administrativo e disciplinar do Judiciário, o Conselho Nacional de Justiça (Sadek, 2010).

Abaixo veremos as principais alterações efetivas que a reforma do Judiciário implementou e seus ganhadores e perdedores.

\begin{tabular}{|c|c|c|}
\hline \multicolumn{3}{|c|}{ Tabela XI - Principais Alterações da Reforma do Judiciário } \\
\hline Modificação & Ganhadores & Perdedores \\
\hline $\begin{array}{l}\text { Aumento do poder da Cúpula do Judiciário } \\
\text { (CNJ, CNMP repercussão geral, súmula } \\
\text { vinculante) }\end{array}$ & $\begin{array}{l}\text { Cúpula do Judiciário, OAB, } \\
\text { Cúpula do Ministério Público; }\end{array}$ & $\begin{array}{l}\text { Tribunais inferiores, } \\
\text { Escritórios de } \\
\text { advogados } \\
\text { especializados em } \\
\text { recursos ao STF }\end{array}$ \\
\hline $\begin{array}{l}\text { Regulação sobre o tribunais inferiores } \\
\text { (processo disciplinar, administração dos } \\
\text { tribunais, fortalecimento da meritocracia, maior } \\
\text { controle orçamentário) }\end{array}$ & Juízes de direito meritórios & $\begin{array}{l}\text { Juízes de direito não } \\
\text { meritórios, juízes } \\
\text { decanos }\end{array}$ \\
\hline $\begin{array}{l}\text { Regulação sobre o Ministério Público } \\
\text { (processo disciplinar, maior controle } \\
\text { orçamentário) }\end{array}$ & Difuso & $\begin{array}{l}\text { Demais membros do } \\
\text { Ministério Público }\end{array}$ \\
\hline $\begin{array}{l}\text { Criação e fortalecimento dos direitos } \\
\text { fundamentais (direito à celeridade judicial, } \\
\text { tratados internacionais com força constitucional, } \\
\text { adesão ao tribunal penal internacional, direito à } \\
\text { privacidade, federalização dos crimes contra os } \\
\text { direitos humanos) }\end{array}$ & Difuso & Difuso \\
\hline Fortalecimento das Defensorias Públicas & Defensorias Públicas & Difuso \\
\hline $\begin{array}{l}\text { Fortalecimento e ampliação do poder } \\
\text { normativo da Justiça do Trabalho }\end{array}$ & Justiça do Trabalho & Difuso \\
\hline Justiça Itinerante e Descentralizada & Difuso & Difuso \\
\hline Justiça militar com maior presença de civis & $\begin{array}{l}\text { Juízes de direito; tribunais } \\
\text { militares }\end{array}$ & $\begin{array}{l}\text { Juízes militares, } \\
\text { corporações militares }\end{array}$ \\
\hline Modificação nas atribuições jurisdicionais & $\begin{array}{l}\text { STF, governadores de Estado, } \\
\text { mesas das assembléias } \\
\text { legislativas, Conselho Federal } \\
\text { da OAB, partidos políticos com } \\
\text { representação no congresso } \\
\text { nacional, confederação sindical } \\
\text { ou entidade de classe de âmbito } \\
\text { federal, Governador e mesa da } \\
\text { assembléia do distrito federal }\end{array}$ & STJ \\
\hline
\end{tabular}




\subsection{1 - Direitos Fundamentais}

A reforma cria um novo direito no inciso ao artigo $5^{\circ}$ da Constituição: o direito à celeridade processual. Outros quatro pontos reforçam a garantia dos direitos fundamentais na Constituição: (1) prescreveu-se que o Brasil se submeterá ao tribunal penal internacional no qual tenha manifestado adesão; (2) estabelece que os tratados internacionais sobre direitos humanos terão força constitucional, caso aprovados por um quórum de 3/5 do Congresso; (3) possibilita a transferência de crimes contra os direitos humanos para a Justiça Federal, (4) permite que, a fim de preservar o direito à intimidade, os juízes divulguem os resultados das ações judiciais apenas às partes e (5) permite que os tribunais de justiça criem varas especializadas em conflitos agrários.

Todos esses temas não produzem nem perdedores nem ganhadores concentrados. Em parte porque as reformas parecem ter só ganhos, como é o caso da preservação do direito à privacidade nas ações judiciais. Em outros casos, as propostas dependem de outras decisões futuras (como os tratados internacionais, tribunal penal internacional e justiça agrária). O princípio da celeridade é mera declaração de intenção e não interfere com interesses específicos de nenhum ator. Assim, podemos pensar que a inclusão destes itens não gera problemas políticos para a reforma, pois não há perdedores claros. Não há motivos materiais para um ator preferir o status quo à proposta (a não ser por motivos de opinião).

\subsection{2- Fortalecimento e Ampliação da Força Normativa da Justiça do Trabalho}

Um segundo grupo de propostas teve por consequência o fortalecimento da Justiça do Trabalho. Os tribunais trabalhistas tiveram suas atribuições mais bem delimitadas. Muitas das atividades que a Justiça do Trabalho já exercia (como decidir sobre direito de greve e danos morais) foram constitucionalizadas. A Justiça do Trabalho também ganhou maior poder para decidir dissídios trabalhistas e julgar questões relativas à greve em serviços essenciais. O Tribunal Superior do Trabalho teve sua composição alterada. Instituiu-se definitivamente o "quinto" para a escolha dos advogados e membros do Ministério Público que ocuparam o TST. Na prática, isso reduziu em um membro o número de ministros com esta origem, fortalecendo os juízes 
de carreira. A reforma também retirou definitivamente as menções aos juízes classistas na Constituição, completando o processo que se iniciou com a Emenda 24, quando houve a extinção deste cargo. A reforma cria a "Escola Nacional de Formação e Aperfeiçoamento de Magistrados do Trabalho", cujos cursos serão obrigatórios para o ingresso e progressão na carreira de juiz do trabalho. Também fica criado um conselho que servirá como controle da cúpula da Justiça do Trabalho sobre os tribunais inferiores, nos moldes do Conselho Nacional de Justiça.

Essas propostas se caracterizam por beneficiar fortemente um setor: a cúpula da Justiça do Trabalho, notadamente os juízes de carreira. Tiveram pequenas perdas os advogados e membros do Ministério Público. Os juízes de instâncias inferiores tiveram sua autonomia reduzida com o fortalecimento da cúpula. Os juízes classistas, que já haviam sido extintos anteriormente pela Emenda 24, perderam definitivamente suas menções no texto constitucional. O segundo parágrafo do Artigo 114 permite que outro tipo de representação dos trabalhadores participe dos dissídios, pois foi retirada a menção explícita aos sindicatos. Contudo, nada indica que os sindicatos atuais perderão seu poder de participar de dissídios supervisionados pela justiça. Apenas se abriu a chance de categorias sem representação sindical também participar. Ou seja, as categorias que não gozam de representação sindical deixaram de serem "párias" dos dissídios trabalhistas. A menção ao direito de greve apenas constitucionaliza uma situação a muito tempo consolidada na jurisprudência.

Os resultados desse conjunto de medidas não são difíceis de compreender. A Justiça do Trabalho como um todo tem seu poder fortalecido e normatizado através da constitucionalização e a ampliação de suas atribuições. Nas relações de poder interna aos tribunais, a cúpula nacional sai fortalecida frente aos tribunais inferiores, os membros do Ministério Público e os advogados, que perderão um cargo na cúpula dos tribunais trabalhistas. No entanto, essa perda foi mais do que compensada com os cargos ganhos no Conselho Nacional da Justiça do Trabalho.

\subsection{3 - Reformulação da Justiça Militar}

A Justiça Militar estadual teve definitivamente consolidada sua atribuição de julgar os crimes cometidos pelos policiais militares contra civis. Porém, juízes de direito 
foram transferidos para os tribunais militares e passaram a julgar esses crimes. Essa foi uma decisão de meio-termo dentro da reforma, pois a proposta original do deputado Hélio Bicudo propunha o simples fim dos tribunais militares. Durante muito tempo a Justiça Militar foi acusada de ser corporativista, evitando condenar policiais militares em crimes contra civis. A proposta, assim, tem o objetivo de aumentar a preservação dos direitos dos civis e ao mesmo tempo preservar tanto a estrutura da Justiça Militar quanto sua atribuição de julgar questões militares intracorporis.

\subsection{4- Justiça Descentralizada e Defensoria Pública}

A reforma também propõe o aperfeiçoamento do Judiciário com a descentralização dos tribunais e o fortalecimento das defensorias. A Justiça Federal, os Tribunais de Justiça e o Ministério Público poderão atuar descentralizadamente, servindo-se, para isso, de equipamentos públicos e comunitários. Foi uma forma de ampliar a garantia dos direitos em regiões distantes das sedes dos tribunais.

A Defensoria Pública teve assegurada sua autonomia funcional, administrativa e orçamentária. Essa organização, que tem uma função vital no Brasil, saiu fortalecida, portanto, dada a grande quantidade de pessoas que não podem pagar um bom advogado privado.

Vemos que as propostas não apresentam um claro prejudicado, não havendo motivo para ser atacada por grupos localizados. No caso da defensoria, a proposta gera um benefício evidente ao órgão, fazendo com que seja racional a este apoiar a reforma.

\subsection{5- Modificação nas Competência e Direitos Jurisdicionais}

A reforma também altera algumas competências jurisdicionais. O provimento para a intervenção em caso de recusa à execução de Lei Federal sai do STJ e vai para o STF. Essa proposta adéqua melhor a referida competência, pois que se trata de assunto claramente federativo, cabendo melhor à corte constitucional (e não à corte de justiça) decidir. Caso parecido acontece com a homologação de sentença estrangeira e a concessão de exequatur às cartas revogatórias. Elas deixam de ser de atribuição do STF 
e passam a ser do STJ. Claramente trata-se de um assunto de justiça e não constitucional. Assim, essa medida "desocupa" o STF e lhe permite dedicar-se à sua causa principal: julgar questões constitucionais. Na contagem dos ganhos e perdas, o Supremo ganhou duas vezes, pois adquiriu uma atribuição que é, muito intensiva em poder e pouco intensiva em trabalho, e perdeu uma atribuição que é pouco intensiva em poder e muito intensiva em trabalho.

A reforma também amplia os atores que podem pedir ação declaratória de constitucionalidade (ADC) para o Supremo. Ficou determinado que os mesmos atores que podem propor ADINs (ação direta de inconstitucionalidade) podem propor ADC. Isso beneficia os governadores, as mesas das assembleias estaduais, os partidos com representação no congresso e as confederações e entidades de classe de âmbito nacional. A reforma também equipara o Distrito Federal aos demais estados quanto ao direito de propor ADINs e ADCs. Novamente temos um caso de emenda com ganho determinado e perda indeterminada.

\subsection{6- Aumento do poder da Cúpula do Judiciário}

Chegamos à parte principal da reforma. Ela cria alguns instrumentos que empoderam a cúpula do Judiciário, notadamente o Supremo Tribunal Federal. O Supremo ganha dois novos instrumentos: (1) a súmula vinculante e (2) a exigência de repercussão geral para a aceitação de recurso extraordinário.

O primeiro instrumento permite ao Supremo, após reiteradas decisões sobre matéria constitucional, instituir súmula vinculante. Essa súmula obriga todos os tribunais, bem como toda a administração direta e indireta de todos os poderes em todos os níveis federativos, a seguir determinada interpretação da lei. Na prática, o Supremo ganha a força de regulamentar leis. Em alguns casos, tal poder chega a ser análogo ao de criar leis ${ }^{52}$.

Esse foi o ponto mais controvertido da reforma, pois ele reduziria seriamente autonomia dos tribunais inferiores. O objetivo da súmula vinculante era reduzir as

\footnotetext{
${ }^{52}$ Foi justamente isso que aconteceu após à aprovação da reforma. O fỉm do nepotismo no Judiciário, um dos pontos que malograram durante a tramitação da reforma, foi implementado através de resolução do CNJ. Após uma série de contestações judiciais, a resolução foi transformada em súmula vinculante e estendida aos poderes Executivo e Legislativo, criando uma nova lei, na prática.
} 
possibilidades de interpretação das leis, tornando o sistema mais rápido e seguro. Muitos parlamentares defendiam, no entanto, uma reforma menos restritiva aos tribunais inferiores, como a súmula impeditiva de recurso. Além dos tribunais inferiores, mobilizaram-se contra a reforma os escritórios de advogados sediados em Brasília que se especializaram em entrar com recursos nos tribunais superiores.

O segundo instrumento que o Supremo ganhou foi a "repercussão geral". Ela permite que o tribunal recuse recursos que não tenham sérias questões de interpretação constitucional. Na prática, o Supremo ganha o direito de determinar a própria agenda. A intenção da proposta é desafogar o Supremo da quantidade fenomenal de recursos que ele precisa julgar todos os anos. Os principais opositores da reforma foram os já referidos escritórios de advocacia especializados em recursos para os tribunais superiores.

Mas o maior de todos os poderes que a cúpula do Judiciário ganhou foi a reformulação do Conselho Nacional de Justiça $(\mathrm{CNJ})$. Tal órgão, que antes tinha uma existência quase simbólica, passou a ser o controlador administrativo e disciplinar do Judiciário. A proposta nasceu da ideia de se criar um controle externo do Judiciário, porém, sua configuração se assemelha mais a uma ampliação do controle interno da instituição. Isto pode ser visto na composição do Conselho, formado por quinze membros, sendo nove juízes, dois membros do Ministério Público, dois advogados indicados pela $\mathrm{OAB}$ e dois cidadãos de notório saber jurídico indicados pelo Congresso. A presidência do Conselho cabe a um ministro do STF.

O CNJ passou, também, a ter poder para sustar decisões administrativas (inclusive nomeações), expedir atos regulamentares que visam ao cumprimento do estatuto da magistratura e propor ações penais contra os juízes ao Ministério Público. Ele também poderá receber reclamações contra os juízes e contra os órgãos que prestam serviços notariais. Pode abrir processo administrativo disciplinar contra membros do Judiciário. Ele também elaborará relatórios semestrais sobre o desempenho da Justiça e instalará ouvidorias nos estados para receber denuncias. A reformulação do $\mathrm{CNJ}$ foi o ponto mais atacado pelos membros do Judiciário avessos a mudanças, pois foi um sério ataque à autonomia dos tribunais.

O Ministério Público também ganhou um conselho com funções disciplinares e administrativas, o CNMP. Suas atribuições são o espelho do CNJ aplicado aos promotores. Ou seja, os princípios centralizadores aplicados aos tribunais foram aplicados ao Ministério Público. 
Em geral, pode-se ver que o sentido geral da reforma é um reforço da cúpula e uma perda de autonomia das instâncias inferiores, sendo essa a principal clivagem da reforma.

Uma clivagem secundária, mas relevante, foi a oposição dos escritórios de advocacia que atuam junto ao Supremo Tribunal Federal. Contudo, deve-se considerar que essa oposição não é dos advogados em geral, mas de um nicho específico e bem restrito (ainda que possa estar bem próximo ao poder). A entidade que comumente atua para defender a classe dos advogados, a Ordem dos Advogados do Brasil, foi beneficiada com a criação de dois cargos no superfortalecido CNJ, um trade off foi mais do que generoso.

\subsection{7 - Regulamentação sobre os tribunais inferiores}

Por fim, a reforma coloca uma série de determinações sobre o funcionamento dos tribunais de justiça, com vistas a coibir abusos e melhorar o desempenho dos tribunais. Esse foi o ponto com o maior número de itens alterados da Constituição (ver no anexo a este capítulo).

As regras para a promoção de merecimento foram alteradas para incluir critérios de desempenho. Ficou proibido promover juízes que retiverem injustificadamente autos em suas mãos. Facilitou-se a rejeição da promoção dos juízes mais antigos, o que ajudou a promoção pelo mérito. As regras de remoção ou de permuta de juízes ficaram igualadas às regras de promoção pelo mérito. Criou-se a "Escola Nacional de Formação e Aperfeiçoamento dos Magistrados", cujos cursos serão obrigatórios para o ingresso e promoção na carreira de juiz.

A administração dos tribunais também foi reformada. Determinou-se que as comissões administrativas dos tribunais serão paritárias entre os juízes mais antigos e os eleitos pelo tribunal pleno. As decisões administrativas passaram a ser obrigatoriamente tomadas em sessões públicas. Ficou permitido que decisões de mero expediente fossem delegadas a funcionários administrativos. Extinguiu-se o Tribunal de Alçada, integrando seus membros e bens aos tribunais de justiça. Aumentou-se as exigências de disciplina orçamentária dos tribunais, pois o Executivo ganhou o poder de decidir o orçamento do Judiciário, caso este não entregue sua proposta a tempo. Também ficou determinado que 
os tribunais não podem criar despesas que não constem em suas peças orçamentárias, a menos que o legislativo libere créditos suplementares.

O regime disciplinar dos juízes também ficou mais rígido, pois o quórum para a aprovação de penalidades nos tribunais caiu de dois terços para a maioria absoluta. Ficou proibida a doação de pessoas e organizações privadas para os juízes. Estipulou-se que as custas e emolumentos se restringem às atividades específicas da justiça. Também foi instituída uma quarentena de três anos para juízes poderem advogar em tribunais dos quais já participaram.

O Ministério Público também ganhou um código disciplinar mais estrito. Diminuiu-se o quórum das sanções disciplinares para a maioria absoluta. Ficou proibido o recebimento de auxílios e contribuições de pessoas e organizações privadas. Ficou instituída a quarentena de três anos. Foi proibida a atuação político-partidária dos membros do Ministério Público. O estatuto da magistratura passou a ser aplicado, no que couber, aos promotores. Os mesmos controles orçamentários que passaram a vigorar na justiça foram aplicados ao MP. Contudo, deve-se considerar que o Ministério Público não julga processos. Ele propõe a ações que podem proceder ou não. Quem decide a pertinência das ações dos promotores é a justiça. Portanto, o risco de responsabilização dos promotores é bem menor. Não foram impostos novos critérios de produtividade para a atuação dos membros do MP. A súmula vinculante não atinge os promotores da mesma forma que atinge os juízes de primeira e segunda instância.

Duas propostas, particularmente, interferem nos interesses dos juízes: o fim das férias coletivas do Judiciário e a distribuição imediata dos processos. Os juízes têm três meses de férias por ano. Durante a tramitação da reforma, foram feitas tentativas de se diminuir esse tempo, mas isso não figurou na versão final da reforma. Porém, conseguiu-se pelo menos acabar com as férias coletivas, que eram uma verdadeira excrescência dos tribunais brasileiros. A distribuição imediata evitou que os juízes usassem de recursos de expediente para evitar a responsabilidade. Como os processos demoravam anos para serem distribuídos, os juízes podiam desresponsabilizar-se por eles.

Há também algumas compensações na proposta. Permitiu-se que os juízes e membros do Ministério Público possam residir fora de suas comarcas, desde que tenham autorização do tribunal ou do chefe da instituição. Foi criada a exigência de diploma em direito e experiência mínima de três anos para ingressar no cargo de juiz, o 
que atendia à reivindicação da classe pelo prestígio do diploma de bacharel e contra a entrada de juízes e promotores extremamente jovens nos tribunais.

\subsection{8 - A Estratégia Política da Reforma do Judiciário}

A estratégia política da reforma do Judiciário foi focar todas as perdas em um único ator, a saber, os tribunais inferiores.

Quando há ator claramente perdedor, pode-se conciliar com ele ou enfrentá-lo. Pode-se dar compensações através de instrumentos de log-rolling ou simplesmente levar a proposta a plenário e ver quem tem mais votos. Tanto o acordo quando o enfrentamento são bem mais fáceis quando as perdas são concentradas em um pequeno número de atores. No caso da Reforma do Judiciário, as perdas recaem recorrentemente sobre os tribunais inferiores. Certamente isso fez com que uma grande parte dos juízes se opusesse à reforma.

Não surgiu daí, contudo, um problema de multidimensionalidade. Como explicado no capítulo anterior, o problema só surge quando uma proposta adicional provoca uma clivagem interna à coalizão de apoio à proposta. Descontentar os descontentes não provoca a diminuição do winset. Pode-se perfeitamente pensar que todos os juízes de primeira e segunda instância (quiçá todos os membros de início de carreira do Ministério Público) estivessem se opondo à reforma. Mas eles teriam força para vetar a proposta? Ao que tudo indica, não. Os parlamentares deram um voto de desconfiança aos tribunais inferiores. Eles foram responsabilizados pelas mazelas do Judiciário. Acharam que era melhor criar regulamentos e tutelas sobre eles. A cúpula togada foi investida de poder para cumprir essa tarefa.

Alguns escritórios de advocacia também foram prejudicados com uma menor acessibilidade ao Supremo Tribunal Federal. Porém, deve-se ressaltar que os custos de tal proposta são mais do que concentrados, são concentradíssimos. A grande e poderosa entidade de defesa dos bacharéis, a $\mathrm{OAB}$, foi beneficiada com cadeiras nos órgãos que farão o controle administrativo geral do Judiciário, Ministério Público e Justiça do Trabalho. Por isso, teria pouco a ganhar em atrasar ainda mais a reforma. Deve-se realçar que mesmo os referidos escritórios de advocacia não tiveram que fechar as 
portas por causa da reforma, pois as regras para os recursos nos demais tribunais superiores (STJ, TST, STM, TSE) não foram alteradas.

Por fim, deve-se dizer que, ao contrário da reforma tributária, os principais pontos da reforma do Judiciário não tinham as características que Wilson chamou de "política dos empreendedores". É verdade que os custos das propostas eram concentrados, mas os benefícios também eram concentrados. As propostas prejudicavam os tribunais inferiores e uma certa parcela dos advogados, mas beneficiavam fortemente a cúpula dos juízes, a Justiça do Trabalho, a Defensoria Pública e a OAB. Mesmo dentro da classe dos juízes inferiores a reforma não impunha custos indiscriminados. As regulamentações sobre os tribunais inferiores facilitavam a punição disciplinar aos juízes e criavam dificuldades para a promoção por antiguidade, mas por outro lado facilitavam a promoção pelo mérito. Acabava-se com as férias coletivas dos tribunais, mas permitia-se que os juízes morassem fora de suas comarcas. Para cada proposta que impunha inequivocamente custos a um setor do Judiciário, havia outra dava ganhos inconteste ao setor prejudicado e até mesmo a outro setor. Assim, os articuladores da reforma do Judiciário conseguiram escapar do dilema das reformas que objetivam "uma melhora da eficiência geral do sistema", que decorre da imposição de custos concentrados, imediatos e certos a um setor, prometendo ganhos difusos, de longo prazo e incertos para toda a população.

Disso, conlui-se que a reforma do Judiciário, apesar de ser uma reforma extensa, não é multidimensional. Existe uma clivagem muito clara em praticamente todos os seus pontos: custos concentrados nos tribunais inferiores e ganhos concentrados nas cúpulas do Judiciário, Ministério Público e OAB.

\section{3 - Reforma Administrativa}

A reforma administrativa (PEC 173/1995; EC 19/1998) foi idealizada dentro do Ministério da Administração e Reforma do Estado do governo Fernando Henrique Cardoso. O documento intitulado Plano Diretor da Reforma do Aparelho do Estado propunha uma ambiciosa reforma, na qual o modelo "burocrático" de administração seria superado pelo modelo "gerencial", que incorporaria a gestão por resultados dentro do Estado (MARE, 1995). Porém, a proposta enviada ao Congresso era bem mais sucinta e conservadora. Basicamente se propunha: 
- A possibilidade de contratação de estrangeiros na forma da lei;

- A introdução do processo seletivo público, mais simples que o concurso público, para admissão de cargos não estáveis;

- A destinação de até $20 \%$ das vagas em concursos para servidores;

- A obrigação de aprovação legislativa para qualquer benefício ou aumento salarial para servidores;

- A supressão da exigência de isonomia para os vencimentos dos servidores da administração pública;

- A supressão da referência à irredutibilidade dos vencimentos dos servidores, restando apenas a irredutibilidade do salário base;

- A flexibilização das regras de estabilidade do servidor público, podendo eles serem demitidos por insuficiência de desempenho ou "excesso de contingente";

- O aumento das exigências do estágio probatório. Seu tempo fica aumentado para cinco anos e uma comissão julgadora avaliará o desempenho do funcionário;

- A revogação da obrigadoriedade de regime jurídico único para as instituições de ensino;

- O estabelecimento de um teto para os salários do funcionalismo, incluindo os inativos, igual ao salário do presidente;

- A possibilidade dos entes federativos se consorciarem para a gestão de funções ou serviços, podendo haver transferências de bens e pessoas entre os entes;

- Flexibilização da gestão de empresas estatais eliminando-se a exigência de autorização legislativa para a fusão, cisão ou incorporação de empresas que estão sob o Programa Nacional de Desestatização, bem como para a criação de subsidiárias;

- A transferência os funcionários federais que atuavam nos ex-territórios federais para os respectivos estados;

Como se pode ver, a reforma, longe de propor grandes mudanças de paradigmas, propôs uma série relativamente longa de medidas que visavam a reduzir o poder do funcionalismo. As maiores inovações da proposta surgiram durante a tramitação da proposta, por iniciativa dos parlamentares. Por exemplo, a tão propalada inclusão do princípio da "eficiência" como uma das bases da gestão pública só foi incluída no Senado, quando a proposta já tinha dois anos de tramitação. 
O governo FHC demorou cerca de três anos para aprovar a proposta. Tal como a reforma do Judiciário, a reforma administrativa teve uma longa e gradual tramitação. A proposta original tinha 1444 palavras, alterava treze artigos e dezenove itens da Constituição. O relator da comissão especial, deputado Moreira Franco, criou um substitutivo com 3372 palavras, alterando quatorze artigos e setenta e oito itens. Em plenário, a reforma ganhou cerca de 1000 palavras, indo para 4310 termos, alterando dezoitio artigos da Constituição e noventa e seis itens. A partir daí pouco se alterou, pois a Emenda 19 de 1998 tinha 4240, alterava dezenove artigos e noventa e quatro itens.

Abaixo estão as principais propostas da reforma administrativa.

\begin{tabular}{|l|c|c|}
\hline \multicolumn{2}{|c|}{ Tabela XII - Principais Alterações da Reforma Administrativa } \\
\hline \multicolumn{1}{|c|}{ Modificação } & Ganhadores & Perdedores \\
\hline $\begin{array}{l}\text { Inclusão de princípios “gerenciais" na } \\
\text { administração pública (princípio da eficiência, } \\
\text { maiores poderes para os usuários de serviços } \\
\text { públicos, metas e autonomia para os órgãos da } \\
\text { administração indireta, escolas de governo, } \\
\text { consórcios públicos). }\end{array}$ & Difusos & Difusos \\
\hline $\begin{array}{l}\text { Reforma nos vencimentos do cargos eletivos } \\
\text { (legalidade para os reajustes, possibilidade de } \\
\text { aumentar vencimentos da própria legislatura, } \\
\text { convocação extraordinária, substituição dos } \\
\text { vencimentos pelos subsídios). }\end{array}$ & governadores, prefeitos & governadores, prefeitos \\
\hline $\begin{array}{l}\text { Empresas Públicas (maior flexibilidade para a } \\
\text { criação de empresas públicas, lei das licitações, } \\
\text { mudança dos estatutos das empresas) }\end{array}$ & Difuso & Empresas Públicas \\
\hline $\begin{array}{l}\text { Polícia (assegura a manutenção das polícias } \\
\text { militar e bombeiros do Distrito Federal, política } \\
\text { aeroportuária, ferroviária, rodoviária; fim da } \\
\text { isonomia dos delegados com outras carreiras } \\
\text { análogas) }\end{array}$ & DF, Polícia Federal & Delegados Estaduais \\
\hline $\begin{array}{l}\text { Ex-territórios (transferências de funcionários) } \\
\begin{array}{l}\text { Servidores Públicos (reforma dos vencimentos, } \\
\text { gestão, concursos públicos e maior controle } \\
\text { fiscal) }\end{array}\end{array}$ & Ex-territórios & Difuso, Governos \\
\hline
\end{tabular}

Longe do tom reformador e ambicioso do Plano Diretor, a Emenda 19 se concentrou em acabar com uma série de pequenos ralos por onde esvaíam-se recursos públicos. Como veremos, a estratégia circunscrever as perdas aos servidores públicos. 
Os próprios parlamentares também tiveram alguns privilégios cerceados, recebendo entretanto, em troca disso, algumas compensações. Ficou permitido, por exemplo, que os parlamentares federais, estaduais e municipais aumentassem o próprio salário, e não mais os salários da legislatura seguinte. Prefeitos, governadores e o presidente também tiveram o mesmo privilégio.

\subsection{1 - Reforma Gerencial}

Uma parte das propostas destinava-se a aplicar os princípios da administração pública gerencial ao Estado brasileiro. Por motivos analíticos, vamos nos deter separadamente sobre as propostas que interferem nos direitos dos servidores.

Apesar do núcleo irradiador das propostas de reforma do Estado ter sido o Ministério da Administração Federal e Reforma do Estado (MARE), notadamente o ministro Bresser Pereira, as propostas mais identificadas com a nova gestão pública não constavam da proposta original. Elas foram incluídas pelos parlamentares ao longo da tramitação da proposta. Não podemos dizer se isso se devia à estratégia do MARE de deixar a proposta crescer no Congresso ou se houve um genuíno protagonismo dos parlamentares.

A reforma acrescentou mais um princípio à administração pública, o princípio da "eficiência"53. União, Estados e Distrito Federal ficaram obrigados a instituir escolas de governo, podendo exigir seus cursos como pré-requisito para os servidores progredirem na carreira. O direito à "reclamação" dos usuários de serviços públicos foi estendido. A proposta determinou que os usuários poderiam participar da gestão dos serviços. Determinou-se, também, que as políticas públicas deveriam ser avaliadas internamente e externamente. Assegurou-se aos cidadãos o direito às informações obtidas pelos órgãos prestadores de serviços. Foram, ademais, previstas leis contra a negligência no serviço público.

Abriu-se, além disso, a possibilidade de os órgãos da administração indireta ganharem autonomia, caso cumprissem metas de desempenho. Nesse sentido, previu-se

\footnotetext{
${ }^{53}$ Os outros são a legalidade, a impessoalidade, a moralidade e a publicidade
} 
que as verbas economizadas com custeio poderiam ser revertidas em investimento para o próprio órgão.

A transparência pública foi ampliada, pois todos os órgãos ficaram obrigados a publicar os vencimentos dos cargos e empregos públicos. A obrigação de prestação de contas foi estendida aos agentes privados que recebem recursos públicos.

Ora, esse conjunto de propostas se caracteriza pelos custos e benefícios difusos. Não há beneficiários nem prejudicados claros. Portanto, esses são casos nos quais os parlamentares puderam decidir referenciados em bases conceituais ou ma opinião de especialistas, sem temer grande pressão de grupos externos. Aliás, deve-se ressaltar, a maior parte destas propostas ainda não possui eficácia jurídica por falta de regulação.

\subsection{2 - Reforma dos Vencimentos dos Cargos Eletivos}

Esse segundo ponto é mais complexo. Os parlamentares estão decidindo sobre reformas que interessam à própria "classe política". E, aqui, houve um equilíbrio entre ganhos e perdas.

O Congresso aprovou a exigência - que constava na proposta original - de que todos os aumentos de salários e ampliação de vantagens aos funcionários devem ser aprovados em lei, incluindo os vencimentos dos políticos eleitos. Contudo, os

parlamentares determinaram que os salários dos funcionários do Legislativo serão aprovados por lei de iniciativa do próprio Legislativo (ao contrário da regra geral de que leis relativas a assuntos administrativos são de iniciativa exclusiva do Executivo). Assim, fica mais difícil aprovar aumentos e benefícios, pois eles terão que ser aprovados por lei e não mais por mera decisão administrativa. As leis possuem um rito de aprovação mais público e com quórum maior do que as resoluções administrativas. A legalidade para o aumento de salários e benefícios foi instituída para os três poderes, tanto no nível federal, quanto estadual e municipal. Com isso o presidente, os governadores e os prefeitos ganham mais força para resistir à pressão dos funcionários por aumentos, bem como para evitar que os benefícios fujam ao controle.

Por outro lado, a relativa dificuldade de se aprovar aumentos de salários para parlamentares e chefes do poder Executivo foi diminuída, pois foi retirada a regra que 
proibia uma legislatura de aumentar os próprios salários. Até a reforma, apenas era apenas possível incrementar os vencimentos da legislatura seguinte. Ficou, além disso, permitido que os parlamentares aumentassem o próprio salário e o salário do presidente, governador ou prefeito.

Foi vedado que os parlamentares recebessem indenizações maiores do que o salário por motivo de convocação extraordinária. Os cargos eletivos do Executivo e do Legislativo, os membros do Judiciário, do Ministério Público, os advogados públicos, os procuradores federais e estaduais, bem como os policiais federais, passaram a receber "subsídios" ao invés de vencimentos. A diferença entre subsídio e vencimento é que o primeiro é necessariamente recebido em uma única parcela mensal, vedados os acréscimos e gratificações ${ }^{54}$.

Uma das poucas categorias de servidores públicos que foram beneficiadas com a reforma foi a dos parlamentares que eram servidores efetivos antes de se elegerem. Foram estendidas aos servidores da administração indireta algumas vantagens que antes eram exclusivas dos servidores da administração direta, como garantia do emprego, poder optar pelo salário do órgão de origem, poder contar o tempo do mandato para fins de aposentadoria e vantagens, etc.

Em suma, percebeu-se que a instituição da legalidade para os aumentos de salários do funcionalismo iria afetar os políticos eleitos. Afinal, parlamentares e chefes do Executivo são servidores públicos. Da mesma forma, a instituição do "subsídio" servia para evitar a proliferação de benefícios que certas categorias de servidores tinham e que acabavam se tornando formas não transparentes nem isonômicas de aumentos de salários. Porém, os próprios parlamentares usavam recorrentemente esse expediente para aumentar sua remuneração. Assim, a reforma acabou afetando os interesses dos próprios parlamentares. Para compensar esses inconvenientes, os políticos trataram de se proteger, removendo uma incomoda determinação da Carta de 1988: a proibição de uma legislatura aumentar os próprios salários.

\footnotetext{
${ }^{54} \mathrm{Na}$ prática, a diferenciação é bastante nebulosa. O Supremo Tribunal Federal incluiu uma série de exceções à regra geral. Há inclusive discussões jurídicas questionando o fato de um servidor receber subsídio ser motivo válido para ele não receber outros benefícios. Mais detalhes podem ser encontrados em (Abreu, 1998) (Borba, 2007).
} 


\subsection{3 - Empresas Públicas}

A reforma visou aumentar o controle do governo sobre as empresas públicas. Flexibilizou-se a criação de empresas estatais, uma vez que a necessidade de aprovação legislativa passou a vincular apenas a autorização da criação da empresa, e não a criação propriamente dita. As empresas públicas passaram a se submeter à Lei de Licitações. Isso afetou as empresas, pois elas perderam flexibilidade para a realização de suas compras. Em contrapartida, aumentou-se a publicidade e o controle do Judiciário.

A reforma estabeleceu que uma lei complementar iria definir: (a) o estatuto jurídico da empresa pública ou sociedade de economia mista; (b) sua função social e formas de fiscalização pelo Estado e pela sociedade; (c) sujeição ao regime jurídico próprio das empresas privadas, inclusive quanto aos direitos e obrigações civis, comerciais, trabalhistas e tributários; (c) licitação e contratação de obras, serviços, compras e alienações, observados os princípios da administração pública; (d) constituição e o funcionamento dos conselhos de administração e fiscal, com a participação de acionistas minoritários (e) os mandatos, a avaliação de desempenho e a responsabilidade dos administradores.

A proposta de implementação de tais medidas servia para ampliar o controle do núcleo político do Estado sobre as empresas, que muitas vezes foram consideradas "Estados dentro do Estado". Do ponto de vista político, a reforma do controle das empresas públicas se situa entre as medidas de reforma gerencial e as perdas dos servidores. Embora essas propostas sejam medidas de governança, a reforma impõe custos concentrados às empresas e a seus dirigentes. Podemos dizer, assim, que se a reforma desagradou aos servidores, isso inclui os funcionários das empresas estatais.

\subsection{4 - Polícia e ex-territórios}

Os delegados de polícia perderam a isonomia com cargos assemelhados em outros poderes e com os advogados públicos. Em compensação, as polícias, principalmente a Polícia Federal, ganharam alguns benefícios concentrados.

A reforma fez algumas pequenas modificações na atribuição das polícias federais. Em primeiro lugar estabeleceu-se que a Polícia Militar e o Corpo de Bombeiros do 
Distrito Federal seriam financiados por fundo próprio mantido pela União. Claramente trata-se de uma medida com benefícios concentrados no Distrito Federal. Também se estabeleceu que a Polícia Federal deveria exercer a função de polícia aeroportuária, e não de polícia aérea - o que confundia suas atribuições com as atribuições da aeronáutica. Deixou-se mais claro que a Polícia Federal e as Polícias Federal Rodoviária e Ferroviária seriam “organizadas e mantidas pela União”, reforçando o prestígio dos órgãos.

A reforma também transferiu os funcionários da União, que exerciam cargos nos antigos territórios federais, para os estados originados pelos respectivos territórios. Outra medida de benefício concentrado.

Essa é uma parte relativamente periférica da proposta, pois regula questões bem específicas. Contudo, nela se nota dois traços marcantes da reforma como um todo: a diminuição dos benefícios aos servidores e a busca por medidas que beneficiam os estados. Apesar de estarmos considerando que muitas das propostas da reforma tiveram, em última instância, ganhadores indefinidos, os governadores, sufocados por uma crise financeira, foram apoiadores especialmente entusiastas da reforma, pois ela abria-lhes espaço para a redução de suas folhas de pagamento.

\subsection{5 - Servidores Públicos}

$\mathrm{O}$ anexo a este capítulo mostra que houve trinta e quatro propostas de reforma administrativa que visavam à modificação da contratação, gestão e remuneração dos servidores. Dentre estas, vinte e cinco impunham custos claros aos servidores públicos. Considerando a reforma como um todo, vinte e sete propostas causavam de alguma forma custos aos servidores ${ }^{55}$.

Determinou-se que a greve no serviço público deveria ser regulada por lei ordinária, mais fácil de se aprovar do que lei complementar. Todos os benefícios e aumentos de salários, daí em diante, teriam de ser aprovados por lei, sendo vedada a criação de benefícios por via administrativa. Foi estipulado para os salários do

\footnotetext{
${ }^{55}$ Aos vinte e cinco pontos citados, acrescentamos o fim da vinculação entre os salários dos delegados de polícia e as funções assemelhadas de outros poderes e a exigência de se divulgar o valor dos cargos e empregos na administração pública.
} 
funcionalismo um teto igual ao subsídio do Ministro do STF. A proibição da vinculação remuneratória foi estendida para incluir todas as vantagens e gratificações. Suprimiu-se a exigência de isonomia salarial entre funções assemelhadas no serviço público. Também foi estendida a proibição de acumulação de acréscimos pecuniários - ou seja, ficou definitivamente proibido o cálculo em cascata para todos os benefícios baseados no salário. Aumentou-se as exceções à "irredutibilidade" dos salários dos servidores, particularmente nos casos afetados pelo estabelecimento do "teto" aos salários e aos benefícios.

A reforma também estabeleceu que mesmo aqueles que ocupam dois empregos públicos devem respeitar o teto constitucional. A própria regra de acumulação foi alterada. Ao invés de se permitir, genericamente, a acumulação de qualquer cargo com compatibilidade de horário, determinou-se especificamente os cargos e as quantidade de acúmulos possíveis (professor, médico e pesquisador). Estende às empresas de economia mista e órgãos indiretos controlados pelo poder público a proibição de acúmulo de cargos públicos.

A reforma elimina a necessidade de regime jurídico único para a administração direta e para as instituições de ensino. Ela estabelece que poderá haver uma lei que fixe a relação entre a maior e a menor remuneração. Além disso, ela aumenta para três anos o tempo de estágio probatório.

A proposta mais polêmica de toda a reforma, no entanto, foi a flexibilização da estabilidade do servidor. Pela proposta, os servidores podem ser demitidos por insuficiência de desempenho, desde que avaliados por uma comissão competente, com direito a contraditório e ampla defesa. Os servidores também podem ser demitidos caso o Município, Estado ou União estejam fora dos limites estipulados pela Lei de Responsabilidade Fiscal ${ }^{56}$. As regras para colocar o servidor em disponibilidade também foram flexibilizadas.

Os estados e municípios também passaram a sofrer controle orçamentário mais rígidos no que toca ao gasto com pessoal. Ficou vedado o uso de empréstimos para gasto com folha de pagamento e estabeleceu-se que, caso o estado ou município não esteja enquadrado nos limites de gasto com pessoal que estipula a Lei de Responsabilidade Fiscal, todos os repasses federais ou estaduais (no caso dos

56 A Lei Complementar 101/2000 (Lei de Responsabilidade Fiscal) foi criada justamente para regulamentar um dispositivo criado pela reforma administrativa, o Artigo 169. 
municípios) serão suspensos. A emenda prevê que nesses casos, até os funcionários do regime jurídico único poderão ser demitidos. Portanto, essa medida é mais atentatória aos benefícios dos funcionários do que aos direitos dos estados. Em verdade, os governadores foram os grandes apoiadores da reforma, pois ficaram empoderados frente com relação aos de seus funcionários.

\subsection{6 - A Estratégia Política da Reforma Administrativa}

Assim, os funcionários públicos tinham pouco a ganhar com a reforma administrativa. A reforma não revolucionou a administração pública brasileira rumo à modernidade gerencial. Ela se concentrou em atacar os benefícios dos funcionários benefícios esses que tinham sido consideravelmente expandidos com a Carta de 1988 e estavam ameaçando os orçamentos dos três níveis de governo.

A reforma administrativa foi polêmica e teve longa tramitação. O primeiro governo Fernando Henrique Cardoso não pode aproveitar os créditos políticos trazidos pela proposta. Ela foi enviada ao Congresso no mês de outubro do seu primeiro ano de mandato e só foi aprovada em junho do último ano - portanto, às vésperas das eleições. Contudo, ela não parece ter um problema de multidimensionalidade. Claramente havia uma única clivagem: ou se é a favor dos direitos dos servidores ou se é a favor da melhor qualidade dos orçamentos municipais, estaduais e federal. Facilmente podemos supor que todo o funcionalismo era contra a reforma. Porém, como dito anteriormente, são poucos os atores que podem se tornar atores com poder de veto à maioria no Brasil. Nesse caso, o funcionalismo não pode se opor à força do presidente, e dos governadores e prefeitos.

Com isso não se está querendo dizer que os argumentos expostos esgotam a explicação para o sucesso da reforma administrativa. Certamente houve intensas negociações, mobilizações de ambos os lados, profundas questões ideológicas sobre qual é a melhor forma de administração pública, etc. No entanto, os únicos atores com perdas concentradas foram os funcionários. Portanto, somente eles teriam interesse em pressionar o Congresso contra a reforma. E para a base parlamentar do governo, enfrentar um único ator é quase sempre sinônimo de vitória. 


\section{5 - Os nós críticos da reforma tributária}

\section{1 - Uma breve história das reformas tributárias pós-1988}

A estrutura tributária montada pela constituinte causou questionamentos desde cedo. Já em 1991, a PEC 48/1991, de autoria do deputado Luis Carlos Hauly (PSDBPR), já propunha algumas alterações no sistema, ainda que de maneira pontual. A proposta do deputado Hauly foi um caso de reforma incremental e bem sucedida, pois se transformou na Emenda Constitucional $n^{o}$ 3, de 1993. Segundo Rangel e Medeiros Neto (2003):

A Emenda Constitucional $\mathrm{n}^{\mathrm{o}}$ 3, de 1993, de iniciativa parlamentar, contou, para sua aprovação, com a efetiva participação das lideranças e bancadas do Poder Executivo. Embora, por sua pequena abrangência, não possa ser chamada de reforma tributária, essa emenda introduziu importantes inovações no Sistema Tributário, como, por exemplo, a tributação sobre a movimentação financeira, a constitucionalização do instituto da substituição tributária e a extinção do Imposto sobre a Venda a Varejo de Combustíveis, de competência municipal. (p. 5)

Esse relativo sucesso contrasta com as estratégias do Executivo e da revisão constitucional. O governo Collor constituiu, no início de seu mandato, a "Comissão Executiva de Reforma Fiscal", composta por cerca de 30 especialistas em finanças públicas e presidida pelo tributarista Ary Oswaldo. A Comissão entregou suas conclusões ao presidente em julho de 1992. Ela propôs uma ampla reforma, que tratou da tributação sobre renda, patrimônio, consumo, criação de um imposto sobre transações financeiras, reformas no sistema de previdência e outros assuntos referentes ao gastos públicos (Viol, 2000, p. 30). A proposta não chegou a se transformar em $P E C$ devido ao caráter breve e tumultuado do governo Collor. Mesmo que a reforma tivesse sido apresentada, as suas chances de aprovação seriam quase nulas, dada a amplitude das propostas. Deve-se ressaltar que algumas propostas da Comissão Executiva, principalmente as que visavam o aumento da arrecadação, como o imposto sobre movimentações financeiras, foram aproveitada na Emenda 3.

As mesmas propostas voltaram ao debate na revisão constitucional, em 1993 e 1994. Uma série de sugestões da Comissão Executiva foi incluída no "emendão" 
proposto pelo deputado relator. Mas, como outras centenas de propostas ingênuas e megalomaníacas, não obteve sucesso (Melo, 1997) (Rangel \& Medeiros Netto, 2003).

Em agosto de 1995, o governo Fernando Henrique Cardoso envia ao Congresso a PEC 175/1995, sua proposta de reforma tributária. Contudo, o governo mostra um claro desinteresse pela proposta. O presidente da comissão especial da reforma, deputado Germano Rigotto (PMDB-RS), e o relator, Mussa Demes (PFL-PI), realizaram inúmeras audiências com especialistas na questão tributária e representantes do setor público e privado. Isso resultou em três pareceres sobre a reforma. Entretanto, nenhum deles foi votado durante o primeiro governo FHC, pois a comissão especial da reforma tributária não conseguia obter quórum para as reuniões, devido às ausências dos deputados governistas (Rangel \& Medeiros Netto, 2003, p. 5).

Os deputados da legislatura iniciada em 1999 resolveram "desengavetar" a PEC 175/1995, à revelia do Executivo. Em novembro de 1999 o relator apresentou seu quarto relatório, contando com o apoio dos deputados da comissão. No dia seguinte (23/11/1999) o Ministério da Fazenda divulga uma nota (Ministério da Fazenda, 1999) onde prevê o apocalipse caso a reforma seja aprovada. A primeira frase na nota é emblemática: a Proposta de Reforma Tributária do Relator Mussa Demes encerra vários problemas estruturais e operacionais, que podem comprometer a eficiência do Sistema Tributário Nacional. Em certa passagem a nota diz que em verdade, o modelo proposto, em vez de primar pela simplificação e racionalização do sistema, acaba por torná-lo ainda mais complexo. Ou então não é preciso dizer que tal sistemática pode, literalmente, quebrar empresas no primeiro período de apuração do imposto. Citando um estudo do Confaz, o Ministério diz que a falta de um mecanismo efetivo de equalização impõe perdas de cerca de $95 \%$ para Tocantins, $61 \%$ para Rondônia, $41 \%$ para o Mato Grosso e 17\% para a Bahia, apenas para citar alguns exemplos.

Deve-se ressaltar, no entanto, que o relator forjou consenso dentro da comissão em prejuízo dos interesses do Executivo. Três propostas são particularmente danosas ao governo: (1) o fim da CPMF, (2) a permissão para que créditos do IVA federal sejam compensados pelo imposto de renda e contribuições sociais e (3) um estranho mecanismo por meio do qual as transferências federais aos governos subnacionais ficam vinculadas à arrecadação dos estados, ou seja, quanto mais os estados arrecadarem, maiores devem ser a transferências a eles próprios. 
Os operadores do governo fizeram um acordo para aprovar o relatório Mussa Demes e propor um novo substitutivo em plenário (Rangel \& Medeiros Netto, 2003, p. 6). Em primeiro de março de 2000, a comissão encerra seus trabalhos de quatro anos e meio aprovando o relatório por 34 a $1^{57}$. Porém, essa quase unanimidade não significou amplo consenso, pois a reforma nunca entrou em pauta no plenário da Câmara dos Deputados. A intenção do governo era aprovar o substitutivo do deputado Antônio Kandir, que resgatava os princípios da proposta original do governo, desfigurados por Demes. Mas mesmo essa proposta não obteve consenso.

Em 2001 o governo lança sua última estratégia para esvaziar a PEC 175/1995: ele envia uma nova proposta ao parlamento, a PEC 383/2001. Essa é a mais enxuta de todas as propostas constitucionais de reforma tributária do Executivo: ela possui apenas 649 palavras, altera cinco artigos e vinte e seis itens da Constituição. Sua estratégia é se concentrar exclusivamente sobre a reforma do ICMS, algo bem diferente das outras propostas que analisadas neste capítulo. Até o final do governo Fernando Henrique Cardoso, nem a PEC 175/1995 nem a 383/2001 foram apreciadas. Ambas as propostas encontraram seu ocaso definitivo em 2003, quando o novo governo as retira do Congresso.

O governo Lula retoma a discussão sobre a reforma tributária em seu primeiro ano de governo. Em 30 de abril de 2003, o Presidente vai ao Congresso, acompanhado dos vinte e sete governadores e de prefeitos da maioria das capitais, entregar pessoalmente as propostas de reforma previdenciária e tributária. O simbolismo do ato era claro: as reformas eram fruto de um amplo consenso prévio, principalmente do ponto de vista federativo.

Mas isso era longe de ser verdade. Desde o início, a reforma teve uma tramitação tumultuada. Primeiro a reforma se mostrou mais polêmica do que inicialmente previsto. Do ponto de vista federativo, os estados e municípios usaram a reforma como oportunidade para pressionar o governo federal por mais recursos. Do ponto de vista do Executivo, as concessões prévias à reforma pareceram ter sido puro desperdício de recursos, pois elas foram ignoradas no parlamento. Quando a proposta chegou no Congresso, a negociação voltou à estaca zero e os atores exigiram mais concessões. Do ponto de vista da sociedade, a reforma é atacada por ser considerada

\footnotetext{
${ }^{57}$ O voto contrário era do deputado Marcos Cintra, que é um defensor do "imposto único".
} 
pequena, "tímida", e ainda propensa ao aumento da carga tributária. Para contornar estas dificuldades, o relator da reforma incorporou uma série de propostas adicionais.

É interessante notar que nas três reformas analisadas, os deputados relatores da comissão especial aumentaram em certa de $100 \%$ o número de palavras com relação à proposta original. As propostas adicionais acabaram piorando as polêmicas, pois o que pode agradar a uns desagrada fortemente a outros. No final se chegou a uma paralisia decisória.

A análise dos jornais do período mostra um intenso empenho do governo na aprovação da $P E C$. Deve-se ressaltar que a $P E C 41 / 2003$ foi a única reforma tributária que foi aprovada pelo plenário da Câmara dos Deputados. Além do esforço genuíno de se aprovar a reforma, o governo também estava interessado em medidas essenciais para garantir seu equilíbrio orçamentário: a prorrogação da CPMF e da Desvinculação das Receitas da União. Quando o governo percebeu que a reforma malograria, ele a desmembrou para garantir que pelo menos essas propostas fossem aprovadas.

No último dia de 2003, a reforma tributária e a da previdenciária foram publicadas no diário oficial, sob os nomes de Emendas Constitucionais 41 e 42 de 2003. A reforma da previdência foi dramática, pois afetou os interesses de um setor tradicionalmente apoiador do partido do presidente Lula: os funcionários públicos. Houve greves, protestos em Brasília e o racha da ala radical do PT para fundar um novo partido, o PSOL. Mas a reforma da previdência foi aprovada. Já a reforma tributária era apenas uma sombra de suas intenções originais. Para se ter uma idéia, a PEC 41/2003 chegou a ter 5517 palavras na versão aprovada pela Câmara dos Deputados, sendo que a Emenda 42 tem “apenas" 1959 palavras.

O Congresso tentou retomar as discussões em 2004 através das Reformas 256, 284 e 294, mas nenhuma delas sequer superou a fase da comissão especial. Em 2007, já no segundo governo Lula, o relator da PEC 41/2003, deputado Virgílio Guimarães (PTMG), apresenta uma nova proposta: a PEC 31/2007. A proposta tem $169^{58}$ co-autores, mostrando o apelo político da reforma.

O governo volta a investir na reforma em 2008, quando envia sua segunda proposta ao parlamento: a $P E C 233 / 2008$. Ela incorpora a maioria dos pontos da $P E C$

\footnotetext{
${ }^{58}$ Esta informação pode ser conferida em

http://www.camara.gov.br/sileg/prop_detalhe.asp?id=347421
} 
31/2007 e adiciona uma nova estratégia: a definição, na própria $P E C$, dos mecanismos de transição para o novo modelo tributário. A versão original da PEC 233/2008 tem nada menos do que 5562 palavras. Se fosse aprovada sem emendas, ela já seria a maior reforma que a Constituição sofreu.

O roteiro típico das reformas tributárias se repetiu mais uma vez. Cada concessão feita aos empresários, governadores, prefeitos (ou a outro grupo de pressão) ampliava ainda mais as polêmicas, obrigando que se fizesse novas alterações na proposta. Ao final, a versão aprovada na comissão especial pelo relator Sandro Mabel (PR-GO), em novembro de 2008 tinha nada menos do que 11840 palavras (a Constituição como um todo tem 37 mil palavras), talvez sendo a proposta de emenda constitucional mais complexa de todos os tempos. E mesmo isso não comovia muitos setores, que alegavam que a reforma era pequena (uma "mini-reforma") que deixava muitos pontos importantes de fora, que não se alterava a tributação sobre a renda e a propriedade etc. A PEC 233/2008 nunca chegou a ser apreciada no plenário da Câmara dos Deputados.

Em agosto de 2009 o principal articulador da reforma, Bernard Appy, deixa seu posto no Ministério da Fazenda, praticamente anulando as chances da reforma ser aprovada no governo Lula.

O que fez com que todas as propostas falhassem, mesmo com toda a pressão política por uma reforma tributária? A resposta não pode estar no sistema político, pois, como ficou demonstrado no capítulo 2, esses sucessivos fracassos do Executivo são uma situação atípica no Brasil. Nosso sistema político é marcado pela hegemonia do Executivo e dos líderes partidários. A reforma contou com o empenho determinado de uma série de atores políticos, muitos deles reconhecidamente talentosos, como Luiz Carlos Hauly, Antônio Kandir, Mussa Demes, Germano Rigotto, Everardo Maciel, Antônio Palocci, Virgílio Guimarães, Arno Augustin, Bernard Appy e Sandro Mabel. E ainda assim as reformas malograram...

Ao que parece, o segredo do fracasso dessas reformas foi uma visão estratégica equivocada. O que causa as incertezas e polêmicas da reforma é o excesso de clivagens, que é decorrente do excesso de propostas. Os atores políticos, desconhecendo esse fato, acreditam que as incertezas das propostas se resolvem com mais propostas, o que só agrava o problema. Abaixo faremos uma exegese das três principais propostas de reforma, a PEC 175/1995, a 41/2003 e a 233/2008, indicando que sua própria 
constituição interna impossibilita o surgimento de uma coalizão de vitória e facilita a formação de uma coalizão de veto.

\section{2 - Uma visão geral das reformas tributárias}

As tabelas XII, XIV e XV mostram as principais propostas das três reformas tributárias $^{59}$. A partir de sua leitura, é forçoso notar tanto a grande quantidade de propostas quanto a diversidade dos ganhadores e perdedores.

Para citar algumas implicações. 1) Ela interfere no interesse dos contribuintes em geral, dos contribuintes de alta renda e das empresas beneficiárias de incentivos fiscais. 2) Ela propõe o fortalecimento das burocracias tributárias, apesar de a autonomia dos fiscos subnacionais diminuir. 3) A indústria é contemplada com a redução do número de impostos, muito embora nada garanta a diminuição da carga tributária. 4) Todas as propostas agradam a setores específicos, como navegação aérea e marítima, rádios, TVs, jornais, agricultores, pequenas empresas, laboratórios farmacêuticos, etc. Por outro lado, há imposição de perdas localizadas na mineração, empresas poluidoras, softwares, serviços e setor financeiro.

Estendendo a lista. De maneira geral, os estados perdem autonomia para legislar sobre seu principal imposto: o ICMS. Os desintrustrializados perdem a possibilidade de instituir benefícios fiscais para atrair empresas. Os industrializados, por outro lado, sofrem sérias perdas de arrecadação com a instituição do princípio do destino. Como será mostrado à frente, a unificação das alíquotas leva a um receio de aumento da carga tributária por parte dos contribuintes, bem como a um temor de diminuição da arrecadação, por parte dos estados.

Os municípios são contemplados com o aumento de seus tributos. Afinal, a PEC 175/1995 permitia a progressividade do IPTU. Ela também substituiu o ISS por um Imposto de Vendas a Varejo. O IVV abarcava todas as bases geradoras do ISS mais

\footnotetext{
59 As PEC 175/1995 e 233/2008 se referem à última versão apresentada, a versão da comissão especial da Câmara dos Deputados. A PEC 41/2003 se refere a versão aprovada em plenário na Câmara do Deputados. Após isto, a reforma foi "fatiada" no Senado Federal, sendo que a versão final aprovada (Emenda Constitucional 42/2003) representa apenas uma parte da proposta.
} 
alimentação e alojamento. Sua alíquota seria única em todo o território, o que evitava a guerra fiscal do ISS. A própria $P E C$ determinava que até a regulamentação definitiva do imposto, a alíquota do IVV seria de 4\%; bem acima da alíquota média do ISS. A reforma também convalidava as taxa sobre serviços específicos, como iluminação, limpeza e conservação das vias. Alguns municípios haviam instituído estas taxas e estavam sofrendo contestações judiciais. Apesar de este problema ter sido em grande parte resolvido pelas emendas 29 e 39, a PEC 41/2003 também tratava do assunto, favorecendo os municípios (e provocando o descontentamento dos contribuintes).

Não iremos esmiuçar os detalhes das propostas. Não haveria ganho argumentativo em descer ao menor dos pormenores. Por isso, faremos a seguir uma análise daquilo que Carlos Matus (2007) chamou de "nós críticos" - as causas principais de problemas, os pontos que geraram os maiores entraves. São eles:

- Unificação do ICMS

- Fim das políticas estaduais de incentivo fiscal

- Instituição do princípio do destino

- Reformulação da cota-parte do ICMS destinada aos municípios.

- Aumento da progressividade dos impostos

- Reforma das vinculações constitucionais 


\begin{tabular}{|c|c|c|}
\hline \multicolumn{3}{|c|}{ Tabela XIII - Análise PEC 175-1995 } \\
\hline Proposta: & Ganhadores & Perdedores \\
\hline $\begin{array}{l}\text { Aumento do Poder do Fisco } \\
\text { (menor sigilo bancário, unificação dos cadastros de } \\
\text { contribuintes, exigência do imposto junto com seu } \\
\text { lançamento) }\end{array}$ & $\begin{array}{l}\text { União, estados e } \\
\text { municípios }\end{array}$ & Contribuintes \\
\hline $\begin{array}{l}\text { Ampliação dos Direitos dos Contribuintes } \\
\text { (noventena, proibição de medidas provisórias sobre } \\
\text { matéria tributária) }\end{array}$ & Contribuintes & $\begin{array}{l}\text { União, estados e } \\
\text { municípios }\end{array}$ \\
\hline $\begin{array}{l}\text { Aumento da Progressividade dos Impostos } \\
\text { (IPTU, ITBI-CM e renda mínima) }\end{array}$ & Classe baixa & Classe Alta \\
\hline $\begin{array}{l}\text { Permissão para medidas anti-dumping no comércio } \\
\text { exterior }\end{array}$ & Indústria & Difuso \\
\hline Contribuição ambiental & $\begin{array}{c}\text { União, } \\
\text { ambientalistas }\end{array}$ & Empresas poluidoras \\
\hline $\begin{array}{l}\text { Compensação de crédito entre impostos e } \\
\text { contribuições } \\
\text { (créditos do IVA compensados com IR e contribuições } \\
\text { sociais) }\end{array}$ & Contribuintes & União, setor social \\
\hline Fim da CPMF & Contribuintes & União \\
\hline $\begin{array}{l}\text { Fim da COFINS, PIS/PASEP e Salário Educação. Eles } \\
\text { são substituídos por um tributo sobre faturamento } \\
\text { não cumulativo e pelo IVA-F } \\
\text { (criam-se novas vinculações para substituir os } \\
\text { impostos específicos) }\end{array}$ & Empresas & Setor social \\
\hline Enforcement dos débitos subnacionais & Difuso & Estados \\
\hline $\begin{array}{l}\text { Fim dos benefícios estaduais para as empresas } \\
\text { (guerra fiscal)(convalida-se os benefícios concedidos } \\
\text { até } 31 / 10 / 1999 \text { ) }\end{array}$ & Difuso & $\begin{array}{c}\text { Estados que se } \\
\text { servem de benefícios } \\
\text { tributários e } \\
\text { empresas } \\
\text { beneficiárias de } \\
\text { incentivos fiscais }\end{array}$ \\
\hline Transferência do ITR para os estados & Estados & Difuso \\
\hline $\begin{array}{l}\text { IVA dual } \\
\text { (substitui-se o ICMS por um IVA compartilhado entre } \\
\text { União e estados, uniforme em todo o território, } \\
\text { isento nas exportações, cobrado nas importações; um } \\
\text { imposto que aproveita créditos relativos ao ativo fixo, } \\
\text { segue o princípio do destino, é fiscalizado pelos } \\
\text { estados com papel suplementar da União e funciona } \\
\text { segundo o modelo do "barquinho"). }\end{array}$ & Difuso & $\begin{array}{l}\text { Estados, } \\
\text { contribuintes }\end{array}$ \\
\hline $\begin{array}{l}\text { Retira a possibilidade de empréstimos compulsórios } \\
\text { para investimentos }\end{array}$ & $\begin{array}{l}\text { Proprietários de } \\
\text { poupanças }\end{array}$ & Difuso \\
\hline Institui impostos extraordinários em caso de guerra & Difuso & Difuso \\
\hline
\end{tabular}




\begin{tabular}{|c|c|c|}
\hline \multicolumn{3}{|c|}{ Tabela XIII- Análise PEC 175-1995 (continuação) } \\
\hline Proposta: & Ganhadores & Perdedores \\
\hline $\begin{array}{l}\text { Instituição do Princípio do Destino no IVA } \\
\text { (em cinco anos as alíquotas interestaduais serão } \\
\text { reduzidas para entre } 1,75 \% \text { e } 3 \% \text { ) }\end{array}$ & $\begin{array}{l}\text { Estados } \\
\text { importadores } \\
\text { líquidos }\end{array}$ & $\begin{array}{l}\text { Estados } \\
\text { exportadores } \\
\text { líquidos }\end{array}$ \\
\hline $\begin{array}{l}\text { Criação de um imposto sobre combustíveis análogo ao } \\
\text { IVA, vinculado ao gasto com infraestrutura de } \\
\text { transportes }\end{array}$ & $\begin{array}{l}\text { Infraestrutura dos } \\
\text { transportes }\end{array}$ & $\begin{array}{l}\text { Estados, } \\
\text { Contribuintes }\end{array}$ \\
\hline $\begin{array}{l}\text { IVV municipal } \\
\text { (imposto municipal sobre vendas a varejo e serviços) }\end{array}$ & Municípios & $\begin{array}{l}\text { Prestadores de } \\
\text { serviços }\end{array}$ \\
\hline $\begin{array}{l}\text { Diminuição de impostos estaduais } \\
\text { (navegação aérea e marítima, rádios e TVs, produtores } \\
\text { rurais). }\end{array}$ & $\begin{array}{l}\text { Navegação aérea e } \\
\text { marítima, rádios e } \\
\text { TVs, produtores } \\
\text { rurais }\end{array}$ & Difuso \\
\hline $\begin{array}{l}\text { Majoração de impostos } \\
\text { (facilita a cobrança de pedágio, bens não corpóreos, } \\
\text { softwares, circulação de produtos de um mesmo titular) }\end{array}$ & Difuso & $\begin{array}{l}\text { Transporte } \\
\text { rodoviário, } \\
\text { informática e } \\
\text { grandes empresas }\end{array}$ \\
\hline $\begin{array}{l}\text { Imposto sobre grandes Fortunas } \\
\text { (ele passa a ser regulado por lei ordinária e não mais } \\
\text { por lei complementar). }\end{array}$ & União & Classe alta \\
\hline $\begin{array}{l}\text { Criação e convalidação de Taxas Municipais } \\
\text { (iluminação, conservação e limpeza de logradouros, } \\
\text { saneamento e segurança) }\end{array}$ & Municípios & Contribuintes \\
\hline $\begin{array}{l}\text { Previdência dos Servidores Públicos } \\
\text { (permite a criação de contribuições para a manutenção } \\
\text { dos fundos de previdência estaduais e municipais). }\end{array}$ & Estados, municípios & Servidores \\
\hline $\begin{array}{l}\text { Redefinição da partilha federativa dos recursos } \\
\text { (a transferência do IR e do IVA para compor o FPE e o } \\
\text { FPM terá como piso } 25 \% \text { do IVA estadual; ou seja, } \\
\text { quanto mais os estados arrecadarem, maior será a } \\
\text { transferência da União para estados e municípios). }\end{array}$ & Estados, municípios & União \\
\hline $\begin{array}{l}\text { Redefinição das vinculações constitucionais } \\
\text { (cria-se novas vinculações, com a função de substituir o } \\
\text { PIS/PASEP e a COFINS). }\end{array}$ & Difuso & Setor Social \\
\hline Prorrogação da Zona Franca de Manaus por dez anos. & Amazonas & Difuso \\
\hline
\end{tabular}




\begin{tabular}{|c|c|c|}
\hline \multicolumn{3}{|c|}{ Tabela XIV - Análise PEC 41-2003 } \\
\hline Proposta: & Ganhadores & Perdedores \\
\hline $\begin{array}{l}\text { Ampliação dos Direitos dos Contribuintes } \\
\text { (noventena; qualquer associação poderá pedir } \\
\text { informações sobre benefícios fiscais; o Senado } \\
\text { terá como atribuição avaliar o sistema tributário; } \\
\text { os estados terão que fornecer informações } \\
\text { eletrônicas sobre a cobrança de impostos). }\end{array}$ & Contribuintes & Difuso \\
\hline $\begin{array}{l}\text { Prerrogativas Especiais às Burocracias Tributárias } \\
\text { (recursos vinculados e prioritários, carreira } \\
\text { específica, ação integrada por convênio) }\end{array}$ & $\begin{array}{l}\text { Burocracias } \\
\text { tributárias }\end{array}$ & Difuso \\
\hline $\begin{array}{l}\text { Aumento da Progressividade dos Impostos } \\
\text { (ITBI-IV, renda mínima) }\end{array}$ & Classe baixa & Classe Alta \\
\hline $\begin{array}{l}\text { Competitividade e Política Industrial } \\
\text { (permissão para alíquotas diferenciadas em } \\
\text { função de política industrial ou comercial; } \\
\text { cobrança de ICMS e contribuições nas } \\
\text { importações) }\end{array}$ & Empresas Nacionais & Difuso \\
\hline $\begin{array}{l}\text { Isenção de impostos na exportação de produtos } \\
\text { primários e serviços - Lei Kandir }\end{array}$ & $\begin{array}{l}\text { Exportadores de } \\
\text { produtos primários } \\
\text { e de serviços }\end{array}$ & $\begin{array}{l}\text { Estados exportadores } \\
\text { de produtos } \\
\text { primários }\end{array}$ \\
\hline $\begin{array}{l}\text { Contribuições não cumulativas } \\
\text { (as contribuições sociais sobre faturamento ou } \\
\text { receita - PIS/PASEP e COFINS - serão não } \\
\text { cumulativas) }\end{array}$ & Indústria & Serviços \\
\hline $\begin{array}{l}\text { Descentralização do ITR } \\
\text { (o ITR pode ser repassado aos municípios, } \\
\text { hipótese no qual eles passarão a ter direito a } \\
\text { 100\% do imposto) }\end{array}$ & Municípios & Difuso \\
\hline Prorrogação da DRU até o fim de 2007 & União & Setor social \\
\hline $\begin{array}{l}\text { Prorrogação da CPMF até o fim de } 2007 \\
\text { (também retira a vinculação da CPMF ao fundo de } \\
\text { combate à pobreza) }\end{array}$ & União & $\begin{array}{l}\text { Contribuintes, setor } \\
\text { social }\end{array}$ \\
\hline $\begin{array}{l}\text { Institui o princípio do Poluidor Pagador } \\
\text { (a tributação poderá discriminar os impostos de } \\
\text { acordo com seu impacto no meio ambiente) }\end{array}$ & $\begin{array}{l}\text { União, estados, } \\
\text { Ambientalistas }\end{array}$ & Empresas poluidoras \\
\hline $\begin{array}{l}\text { Possibilita empréstimos compulsórios para } \\
\text { atender a gastos com desastres ambientais. }\end{array}$ & Difuso & $\begin{array}{l}\text { Proprietários de } \\
\text { poupanças }\end{array}$ \\
\hline $\begin{array}{l}\text { Pequenas Empresas } \\
\text { (institui tratamento privilegiado às pequenas } \\
\text { empresas, com cobrança unificada de impostos } \\
\text { federais, estaduais e municipais). }\end{array}$ & Pequenas empresas & Difuso \\
\hline $\begin{array}{l}\text { Partilha da CIDE-Combustíveis } \\
\text { (aumenta de } 10 \text { para } 25 \% \text { a parcela da CIDE- } \\
\text { combustíveis que é transferida aos estados) }\end{array}$ & estados & União \\
\hline
\end{tabular}




\begin{tabular}{|c|c|c|}
\hline \multicolumn{3}{|c|}{ Tabela XIV - Análise PEC 41-2003 (continuação) } \\
\hline Proposta: & Ganhadores & Perdedores \\
\hline $\begin{array}{l}\text { Criação e convalidação de taxas municipais } \\
\text { (os municípios poderão cobrar taxas sobre } \\
\text { iluminação e limpeza) }\end{array}$ & Municípios & Contribuintes \\
\hline $\begin{array}{l}\text { Unificação do ICMS } \\
\text { (o ICMS passa a ser uniforme em todo o território } \\
\text { nacional, cobrado "por fora" do IPI, isento nas } \\
\text { exportações, cobrado nas importações, perceberá } \\
\text { crédito para o ativo fixo, com no máximo cinco } \\
\text { alíquotas definidas pelo Senado e regulamentadas } \\
\text { pelo CONFAZ; poderá funcionar por meio de um } \\
\text { sistema de câmara de compensação - modelo } \\
\text { "travessia"). }\end{array}$ & Difuso & Estados, contribuintes \\
\hline $\begin{array}{l}\text { Fim dos Benefícios estaduais para as empresas } \\
\text { (guerra fiscal) } \\
\text { (convalida-se os benefícios concedidos legalmente } \\
\text { pelo CONFAZ até o seu fim e os benefícios } \\
\text { concedidos por fora do CONFAZ por onze anos) }\end{array}$ & Difuso & $\begin{array}{l}\text { Estados que se servem } \\
\text { de benefícios } \\
\text { tributários e empresas } \\
\text { beneficiárias de } \\
\text { incentivos fiscais }\end{array}$ \\
\hline $\begin{array}{l}\text { Instituição do Princípio do Destino } \\
\text { (as alíquotas interestaduais de ICMS deverão cair } \\
\text { gradualmente para que após onze anos elas estejam } \\
\text { uniformizadas em } 4 \% \text {; alimentos e remédios terão } \\
\text { alíquota reduzida e serão cobrados na origem) }\end{array}$ & $\begin{array}{l}\text { Estados } \\
\text { importadores } \\
\text { líquidos }\end{array}$ & $\begin{array}{l}\text { Estados exportadores } \\
\text { líquidos }\end{array}$ \\
\hline $\begin{array}{l}\text { Reformulação do ICMS Municipal } \\
\text { (a cota-parte do ICMS pertencente aos municípios } \\
\text { passa a ser determinada por lei complementar) }\end{array}$ & Difuso & $\begin{array}{c}\text { Pequenos municípios } \\
\text { com grandes empresas } \\
\text { industriais, capitais dos } \\
\text { estados pobres }\end{array}$ \\
\hline $\begin{array}{l}\text { Majoração de impostos e taxas estaduais } \\
\text { (facilita a cobrança de pedágio, institui IPVA sobre } \\
\text { barcos e aeronaves, circulação de produtos de um } \\
\text { mesmo titular) }\end{array}$ & Estados & $\begin{array}{c}\text { Transporte rodoviário, } \\
\text { proprietários de barcos } \\
\text { e aeronaves, grandes } \\
\text { empresas }\end{array}$ \\
\hline $\begin{array}{l}\text { Redução de Impostos } \\
\text { (fabricação de jornais, rádios, TVs, medicamentos, } \\
\text { alimentos, informática) }\end{array}$ & $\begin{array}{l}\text { Jornais, Rádios, } \\
\text { TVs,laboratórios, } \\
\text { agricultores, } \\
\text { empresas de } \\
\text { informática }\end{array}$ & Difuso \\
\hline $\begin{array}{l}\text { Estabelece que nenhum setor pode ter CSLL menor } \\
\text { que o setor financeiro }\end{array}$ & União & Setor financeiro \\
\hline $\begin{array}{l}\text { Petróleo e energia Elétrica } \\
\text { (esses produtos, que eram exceção à regra, passarão } \\
\text { a ser cobrados pelo princípio da origem atenuado, } \\
\text { como os demais; a transição demorará onze anos) }\end{array}$ & $\begin{array}{l}\text { Estados produtores } \\
\text { de petróleo e } \\
\text { energia elétrica }\end{array}$ & Difuso \\
\hline $\begin{array}{l}\text { Política de Desenvolvimento Regional } \\
\text { ( } 2 \% \text { do IR e do IPI irão para as regiões pobres) }\end{array}$ & $\begin{array}{l}\text { RJ, ES, MG, N, NE, } \\
\text { CO }\end{array}$ & União \\
\hline $\begin{array}{l}\text { Vinculações Orçamentárias } \\
\text { (os estados podem vincular recursos para cultura e } \\
\text { assistência social) }\end{array}$ & $\begin{array}{c}\text { Setores sociais e } \\
\text { culturais }\end{array}$ & Difuso \\
\hline $\begin{array}{l}\text { Prorrogação da Zona Franca de Manaus por dez } \\
\text { anos }\end{array}$ & Amazonas & Difuso \\
\hline
\end{tabular}




\begin{tabular}{|c|c|c|}
\hline \multicolumn{3}{|c|}{ Tabela XV- Análise PEC 233-2008 } \\
\hline Proposta: & Ganhadores & Perdedores \\
\hline $\begin{array}{l}\text { Ampliação dos Direitos dos Contribuintes } \\
\text { (instituição do Código de Defesa dos Contribuintes; } \\
\text { privilégios aos contribuintes que usarem o sistema } \\
\text { de escrituração fiscal) }\end{array}$ & Contribuintes & $\begin{array}{l}\text { União, estados, } \\
\text { municípios, } \\
\text { Burocracias } \\
\text { tributárias }\end{array}$ \\
\hline $\begin{array}{l}\text { Prerrogativas Especiais às Burocracias Tributárias } \\
\text { (deverá haver uma lei geral da administração } \\
\text { tributária, dispondo inclusive dos direitos, } \\
\text { garantias e obrigações dos servidores) }\end{array}$ & $\begin{array}{l}\text { Burocracias } \\
\text { Tributárias }\end{array}$ & Difuso \\
\hline $\begin{array}{l}\text { Desoneração do Ativo Permanente } \\
\text { (o IVA e o ICMS instituirão aproveitamento } \\
\text { imediato dos créditos do ativo fixo, } \\
\text { respectivamente, no terceiro e oitavo ano de } \\
\text { aprovação da emenda). }\end{array}$ & Empresas & Estados \\
\hline $\begin{array}{l}\text { Extinção do PIS/PASEP, COFINS, CIDE- } \\
\text { combustíveis e Salário-Educação. } \\
\text { (eles serão substituídos pelo IVA-F; a CSLL será } \\
\text { incorporada ao Imposto de Renda) }\end{array}$ & Empresas & Setor social \\
\hline $\begin{array}{l}\text { Desoneração da folha de pagamentos } \\
\text { (as contribuições patronais ao INSS irão diminuir } \\
6 \% \text { em sete anos - sendo substituídas pelo IVA-F; } \\
\text { produtores rurais poderão contribuir pelo } \\
\text { faturamento). }\end{array}$ & Empresas & Setor social \\
\hline $\begin{array}{l}\text { Majoração de impostos estaduais } \\
\text { (minérios, serviços, softwares, circulação de } \\
\text { mercadorias de um mesmo titular, bens de } \\
\text { consumo comprados pelas empresas). }\end{array}$ & estados & $\begin{array}{l}\text { Mineradoras, } \\
\text { serviços, softwares, } \\
\text { empresas. }\end{array}$ \\
\hline $\begin{array}{l}\text { Redução de impostos } \\
\text { (reciclagem, cesta básica, obras de engenharia } \\
\text { [ISS], álcool combustível). }\end{array}$ & $\begin{array}{l}\text { Reciclagem, } \\
\text { agricultura, } \\
\text { construtoras }\end{array}$ & $\begin{array}{c}\text { estados } \\
\text { (principalmente os } \\
\text { pobres ou agrícolas), } \\
\text { municípios }\end{array}$ \\
\hline $\begin{array}{l}\text { Pequenas Empresas } \\
\text { (o IVA e o ICMS instituirão regimes simplificados } \\
\text { para as pequenas empresas). }\end{array}$ & Pequenas empresas & Difuso \\
\hline $\begin{array}{l}\text { Reformulação do orçamento social } \\
\text { (ao invés de o orçamento da seguridade social ser } \\
\text { financiado por contribuições sociais, ele resultará } \\
\text { de uma porcentagem de } 39,7 \% \text { do IR, IVA e IPI) }\end{array}$ & Setor social & Difuso \\
\hline $\begin{array}{l}\text { Poluidor Pagador } \\
\text { (os contribuintes poderão ter tributação } \\
\text { diferenciada conforme a comprovação da redução } \\
\text { ou eliminação de danos ambientais decorrentes } \\
\text { de seu processo produtivo) }\end{array}$ & $\begin{array}{l}\text { União, estados e } \\
\text { municípios, } \\
\text { ambientalistas }\end{array}$ & Empresas poluidoras \\
\hline $\begin{array}{l}\text { Tratados Internacionais } \\
\text { (a proibição de a União isentar tributos } \\
\text { subnacionais não vale para tratados } \\
\text { internacionais) }\end{array}$ & Estados & Empresas \\
\hline
\end{tabular}




\begin{tabular}{|c|c|c|}
\hline \multicolumn{3}{|c|}{ Tabela XV- Análise PEC 233-2008 (continuação) } \\
\hline Proposta: & Ganhadores & Perdedores \\
\hline $\begin{array}{l}\text { Regulações sobre o ISS } \\
\text { (os serviços para o exterior passam a pagar ISS; } \\
\text { lei complementar irá dispor sobre o } \\
\text { estabelecimento prestador, bem como sobre a } \\
\text { cobrança e arrecadação do ISS) }\end{array}$ & $\begin{array}{l}\text { Municípios } \\
\text { (principalmente os } \\
\text { grandes) }\end{array}$ & Serviços \\
\hline $\begin{array}{l}\text { Criação do IVA-F } \\
\text { (institui um imposto federal sobre operações } \\
\text { onerosas com bens e serviços, ainda que } \\
\text { incidentes no exterior [IVA-F]; será não } \\
\text { cumulativo; gerará créditos nas compras de bens } \\
\text { de capital; será cobrado nas importações e } \\
\text { isento nas exportações). }\end{array}$ & Empresas & Setor social \\
\hline $\begin{array}{l}\text { Unificação do ICMS } \\
\text { (o ICMS passa a ser uniforme em todo o } \\
\text { território nacional, isento nas exportações, } \\
\text { cobrado nas importações; perceberá crédito } \\
\text { para o ativo fixo, terá alíquotas definidas por lei } \\
\text { complementar e regulamentadas pelo CONFAZ } \\
\text { [com ratificação do Senado]; funcionará por um } \\
\text { sistema de câmara de compensação - modelo } \\
\text { "travessia"). }\end{array}$ & Difuso & $\begin{array}{c}\text { Estados, } \\
\text { contribuintes }\end{array}$ \\
\hline $\begin{array}{l}\text { Fim dos benefícios estaduais para as empresas } \\
\text { (guerra fiscal) } \\
\text { (convalida-se os benefícios já concedidos até } \\
\text { 05/07/2008; os benefícios concedidos entre essa } \\
\text { data e a da aprovação da emenda podem ser } \\
\text { convalidados pelo CONFAZ) }\end{array}$ & Difuso & $\begin{array}{l}\text { Estados que se } \\
\text { servem de benefícios } \\
\text { tributários e } \\
\text { empresas } \\
\text { beneficiárias de } \\
\text { incentivos fiscais }\end{array}$ \\
\hline $\begin{array}{l}\text { Instituição do princípio do destino no ICMS } \\
\text { (em doze anos, as alíquotas interestaduais } \\
\text { estarão uniformizadas em } 2 \% \text { ). }\end{array}$ & $\begin{array}{l}\text { Estados } \\
\text { importadores } \\
\text { líquidos }\end{array}$ & $\begin{array}{c}\text { Estados exportadores } \\
\text { líquidos }\end{array}$ \\
\hline $\begin{array}{l}\text { Reformulação do ICMS municipal } \\
\text { (estabelece que nenhum município receberá } \\
\text { cota-parte do ICMS maior do que quatro vezes a } \\
\text { correspondente à sua população no estado) }\end{array}$ & Difuso & $\begin{array}{l}\text { Pequenos municípios } \\
\text { com grandes } \\
\text { empresas industriais }\end{array}$ \\
\hline $\begin{array}{l}\text { Petróleo e energia Elétrica } \\
\text { (após treze anos, o petróleo e a energia serão } \\
\text { tributados da mesma forma que os demais } \\
\text { produtos). }\end{array}$ & $\begin{array}{l}\text { Estados produtores } \\
\text { de petróleo e } \\
\text { energia }\end{array}$ & Difuso \\
\hline $\begin{array}{l}\text { Política de Desenvolvimento Regional } \\
\text { (cria o "Fundo Nacional de Desenvolvimento } \\
\text { Regional", destinado a ajudar as regiões pobres } \\
\text { do país) }\end{array}$ & $\begin{array}{l}\text { Estados, regiões } \mathrm{N}, \\
\text { NE e CO, estados, } \\
\text { setor da infra- } \\
\text { estrutura e indústria }\end{array}$ & União \\
\hline $\begin{array}{l}\text { Fundo de Equalização Fiscal } \\
\text { (cria o Fundo de Equalização de Receitas, que } \\
\text { deve garantir que nenhum estado perca recursos } \\
\text { com a emenda). }\end{array}$ & Estados & União \\
\hline
\end{tabular}




\begin{tabular}{|l|c|c|}
\hline \multicolumn{3}{|c|}{ Tabela XV- Análise PEC 233-2008 (continuação) } \\
\hline $\begin{array}{l}\text { Proposta: } \\
\text { Redefinição da partilha federativa dos recursos } \\
\text { (exclui a exigência de a União dividir todos os } \\
\text { impostos que criar; o FPE e FPM serão uma parte } \\
\text { da arrecadação do IR, IPI e IVA; o imposto de } \\
\text { exportação será dividido com os estados; a } \\
\text { repartição dos tributos poderá levar em conta } \\
\text { critérios ambientais) }\end{array}$ & $\begin{array}{c}\text { União, } \\
\text { ambientalistas }\end{array}$ & Estados, municípios \\
\hline $\begin{array}{l}\text { Zona Franca de Manaus } \\
\text { (acrescenta dez anos à Zona Franca de Manaus e }\end{array}$ & Amazonas & \\
aumenta a regulação federal sobre ela). & Difuso \\
\hline $\begin{array}{l}\text { Fim do Fundo de Compensação da Lei Kandir } \\
\text { (após a transição para o destino, em treze anos, } \\
\text { deixa de existir o fundo de compensação da Lei } \\
\text { Kandir) }\end{array}$ & Estados & União \\
\hline
\end{tabular}

\section{3 - Unificação do ICMS}

A unificação e federalização da legislação do Imposto sobre Circulação de Mercadorias e Serviços (ICMS) foi o ponto principal das propostas de reforma tributária. Por diferentes maneiras, todas propuseram a mesma coisa: a normatização sobre o ICMS deixaria de ser competência estadual e passaria a ser competência federal. Os estados continuariam a cobrar e receber o imposto, mas perderiam a autonomia para legislar sobre ele.

Essa proposta tem dois objetivos. O primeiro é tornar o ICMS mais simples, evitando que as empresas tenham que ter assessoria em vinte e sete legislações estaduais diferentes. O segundo objetivo da proposta é acabar com a "guerra fiscal". As PECs 175/1995, 41/2003 e 233/2008 propunham que os estados fossem proibidos de conceder isenções ou concessões fiscais, bem como reduções da base tributária. Essa proposta fez emergir pelo menos cinco clivagens políticas diferentes.

\subsection{1 - Determinação das novas alíquotas (problema federativo).}

A proposta de unificação da legislação do ICMS provocou uma insegurança quanto aos valores futuros das alíquotas do imposto e, consequentemente, quanto à 
arrecadação futura dos governos estaduais. Um dos exemplos mais citados é o petróleo. As alíquotas da gasolina e do óleo diesel variam de $12 \%$ a $25 \%$. Os combustíveis e lubrificantes derivados de petróleo representam cerca de $20 \%$ da arrecadação total do ICMS do país. A participação na arrecadação estadual de ICMS varia de $13 \%$ a $34 \%$ do $\operatorname{total}^{60}$. Essa grande participação na arrecadação dos estados se explica porque os combustíveis combinam alto valor, grande consumo, grande volume (o que dificulta o contrabando) e distribuição relativamente centralizada. Se a alíquota dos derivados de petróleo for unificada, haverá o risco de perdas concentradas de receitas em alguns estados, caso a alíquota mais alta não prevaleça. Haveria então um dilema: ou se unifica as alíquotas "pelo topo", aumentando drasticamente a carga tributária, ou se unifica as alíquotas nos níveis médios, correndo o risco de se penalizar alguns estados.

O mesmo dilema se repete em vários produtos. Cada um deles tem o potencial de gerar uma clivagem política diferente, pois a estrutura produtiva dos estados é muito diferente e o perfil da arrecadação é muito diverso. Para São Paulo, a arrecadação de ICMS de alimentos não é importante (0,27\% do ICMS em 2002), mas para os estados da região Centro-Oeste ela é $\left(5,11 \%\right.$ em 2002) ${ }^{61}$. Já com a produção de remédios e bens de capital se dá o contrário: São Paulo resiste à diminuição da tributação de tais produtos, pois isso lhe traria perdas concentradas; já para os demais estados, as perdas seriam bem menores.

É importante lembrar que a arrecadação é majoritariamente na origem no Brasil. Assim, quando existe um estado especialista na produção de um bem - como no caso dos alimentos, remédios e equipamentos industriais - a desoneração de tributos estaduais sobre esse determinado bem gera uma perda concentrada no estado produtor e um ganho difuso na federação.

Como se não bastasse isso, existe outro problema: a conta dos ganhadores e perdedores não pode ser feita com precisão, pois não se sabe os valores que as alíquotas de cada produto assumirão no futuro. Esse dado não pode ser decidido no momento de votação da emenda constitucional, pois isso não é matéria típica de texto constitucional $^{62}$. As propostas propunham apenas a federalização do imposto. As definições das alíquotas específicas seriam delegadas para outra instância, que poderia

\footnotetext{
${ }^{60}$ Elaboração própria. Dados de 2002 e 2003. Fonte: Confaz; http://www.fazenda.gov.br/confaz/boletim/

${ }^{61}$ Elaboração própria. Confaz; http://www.fazenda.gov.br/confaz/boletim/

${ }^{62}$ A regulamentação desse tipo de imposto costuma ser um calhamaço maior que a própria constituição.
} 
ser uma lei federal, como na PEC 175/1995, ou um colegiado de representantes dos governos estaduais (com ratificação do Senado), como nas PECs 41/2003 e 233/2008. Os congressistas que discutem a proposta sabem que estão entregando a discussão principal para outra arena. Ou seja, além da complexidade inerente da proposta - onde cada produto possui uma clivagem política diferente - existe a incerteza quanto aos resultados da reforma, pois ela depende de discussões futuras. Esta questão aflorou durante a tramitação da PEC 41/2003, como mostra a fala do Dep. Aloysio Nunes (PSDB-SP):

Não voto em algo que mais tarde acarretará a situação de o Governador do meu Estado [São Paulo] dizer a esse órgão administrativo [o colegiado de representantes dos estados] que ele arrebentou com a nossa arrecadação. Os membros do órgão administrativo diriam ao Governador que infelizmente ele seria minoria, porque (...) não houve unanimidade a respeito da matéria. Alguns Estados concordaram, outros não. (...) Na hora da efetiva fixação da alíquota, não sei se por maioria simples ou absoluta, um Estado pode ver brutalmente solapada toda a base financeira de sua autonomia. Como esse Governador vai explicar-se? ${ }^{63}$

Em suma, a unificação do ICMS, do ponto de vista federativo, traz um sério risco de perdas concentradas em alguns estados. Qualquer proposta de reforma tributária que passe pela alteração do ICMS requer, assim, negociações complexas e incertas, pois a conta exata dos ganhadores e perdedores não pode ser feita com precisão, uma vez que ela depende da determinação das novas alíquotas - que será deliberada em outra arena.

\subsection{2 - Determinação das novas alíquotas (carga tributária).}

A unificação das alíquotas também faz surgir outro problema: o temor de aumento da carga tributária. Isso aconteceria caso as alíquotas fossem unificadas "por cima". Como resultado, seria gerada uma clivagem política que dificulta as negociações do ponto anterior, pois limita a estratégia de evitar perdas de arrecadação nos estados

\footnotetext{
${ }^{63}$ Discurso disponível em (notas taquigráficas) http://www2.camara.gov.br/comissoes/ccjc/notastaq/nt20052003.pdf e (áudio) http://imagem.camara.gov.br/internet/audio/Resultado.asp?txtCodigo $=00001112$
} 
com aumento no nível geral dos impostos. Existe, além desse, o risco de haver o pior dos mundos: o nível geral dos impostos aumenta, mas algumas alíquotas não são unificadas "no topo" e causam perdas de arrecadação a alguns estados.

É importante notar que as questões relativas à carga tributária são um dos poucos pontos que têm grande visibilidade social na reforma, sendo intensamente exploradas pela mídia e pela oposição. Isso se deve ao fato de que os custos do aumento de impostos são facilmente compreensíveis para os eleitores, ao passo que as relações intergovernamentais não o são. Nesse sentido, Arnold (1990, p. 205-222), em situação semelhante, mostra que um dos motivos para que seja tão difícil para o Congresso americano aprovar aumento de impostos em tempos de paz, é que os custos dos impostos são claros, ao passo que seus benefícios não são.

Tanto Fernando Henrique Cardoso quanto Lula afirmaram que o objetivo da reforma não era aumentar a arrecadação, mas modernizar e simplificar o sistema tributário. Contudo, eles não conseguiram emitir promessas críveis (credible commitment) no que respeita a esse ponto. Ou seja, muitos setores achavam que havia um grande "risco moral" na reforma, temendo o Executivo a usasse para aumentar o peso dos tributos. As reformas se transformavam em uma "guerra de comunicação" entre a oposição e governo - os primeiros afirmando que o governo pretendia aumentar os tributos e os segundos negando. Nesse ponto, a discussão saía das questões técnicas e institucionais-federativas e passava para a relação governo/sociedade. A unificação do ICMS intercalava, portanto, duas dimensões políticas: a relação entre os níveis federativos e a relação do Estado com a sociedade. Quanto mais se chegava perto de um consenso sobre uma dimensão, mais se afastava do acordo em outra.

\section{4 - Fim das isenções fiscais estaduais (guerra fiscal)}

Um dos pontos mais polêmicos da reforma é o fim dos benefícios fiscais. Durante a tramitação da $P E C 41 / 2003$, o deputado mais combativo contra o fim da guerra fiscal foi Sandro Mabel (PR-GO), ele próprio um empresário beneficiado por incentivos fiscais. Mesmo fazendo parte da base governista, ele, como membro da comissão especial, fazia longos e incisivos discursos contra o fim dos benefícios 
estaduais. Em 2008, na discussão da PEC 233, Mabel conseguiu se tornar relator da reforma, derrotando o próprio partido do presidente, que preferia que a relatoria ficasse nas mãos de Antônio Palocci (PT-SP). Apesar de Mabel ter acatado a determinação geral de fim dos benefícios fiscais, o mero fato político de ele ser relator da reforma mostra a força dos grupos com interesses concentrados na reforma.

Podemos analisar o fim dos benefícios tributários estaduais a partir de três óticas diferentes, a que corrrespondem as três subssessões seguintes deste capítulo.

\subsection{1 - Isenções Fiscais (estados)}

O sistema atual oferece incentivos para a concessão fiscal. Sendo que maior parte da tributação se concentra na origem, quando uma empresa muda sua planta produtiva de um estado para outro, o primeiro perde e o segundo ganha, mesmo que este último tenha reduzido suas alíquotas. Portanto, apesar de a guerra fiscal prejudicar o conjunto da economia nacional, ela beneficia os que dela se saem vitoriosos.

Para os especialistas em economia do setor público, o fim da guerra fiscal é um jogo de soma positiva, pois beneficia o Estado e a economia. No entanto, para os estados, o fim dos incentivos é um jogo de soma-zero, no qual, basicamente, o Estado de São Paulo ganha e os demais perdem. Assim, o dilema das isenções fiscais tende a unir SP, o governo federal e os especialistas em tributação contra os demais estados.

\subsection{2 - Isenções Fiscais (empresas)}

Os estados não são os únicos interessados na guerra fiscal. As empresas também são parte relevante da discussão. Do ponto de vista empresarial, o fim da guerra fiscal é um jogo de custos concentrados e ganhos difusos. Existe um tipo específico de empresa que se beneficia da guerra fiscal. Em geral, são empresas grandes e mais "móveis", ou seja, que não dependem de recursos naturais locais ou de proximidade com o mercado 
consumidor. Elas têm o potencial de barganhar junto aos estados para conseguir redução de tributos para seus novos investimentos. Obviamente, elas tendem a ser contra o fim dos benefícios fiscais. Elas não estão desorganizadas, existem associações, como a ADIAL Brasil ${ }^{64}$, constituídas exclusivamente por indústrias beneficiárias por incentivos fiscais. Esta associação tem uma atuação política ativa, inclusive com uma proposta de lei complementar própria legitimando a política de incentivos fiscais.

Além de serem difusos, os ganhos com o fim da guerra fiscal são incertos e complexos. Os empresários não têm garantia nenhuma de que o fim da disputa federativa não resulte apenas em aumento dos impostos, sendo residuais os efeitos para o conjunto das empresas. Do ponto de vista do empresariado, a tese de que o fim da guerra fiscal representa uma melhora da "eficiência geral da economia" não apresenta nexos claros entre causa e efeito ${ }^{65}$. Mesmo que ela seja verdadeira, a empresa individual não tem garantias de que tal melhora não vá beneficiar mais seus concorrentes do que ela. Assim, do ponto de vista empresarial, o fim dos benefícios fiscais é uma política de custos concentrados e certos e ganhos difusos e incertos.

Mas, além da questão dos benefícios futuros, é preciso acertar a questão das isenções já concedidas. Isso acresce à reforma mais uma dimensão: a jurídica.

A rigor, todos os benefícios concedidos para fins de guerra fiscal são ilegais, pois a Lei Complementar 24 de 1975 - que regula o ICMS - determina que somente o Confaz pode autorizar isenções, mediante decisão por unanimidade. Contudo, a invalidação dos benefícios fiscais levaria a custos demasiadamente severos às empresas e aos estados pobres.

As três reformas propunham a convalidação (anistia) dos benefícios. A PEC 175/1995 determinou que os benefícios sob condição e prazo certo seriam observados até o fim. Além disso, a União instituiria isenção de tributos federais como benefício suplementar aos benefícios estaduais. Já a PEC 41/2003 determinava que deveria haver um prazo de transição, definido em lei complementar, onde os benefícios existentes seriam gradualmente extintos. O relator da PEC 41/2003, Dep. Virgílio Guimarães (PT-

\footnotetext{
${ }^{64}$ Associação Brasileira Pró-Desenvolvimento Industrial (www.adialbrasil.com.br).

${ }^{65}$ Existem poucos estudos sobre a opinião dos empresários sobre a reforma tributária. Pedrosa \& Cornils (2000) entrevistaram os empresários da região metropolitana de Recife. A conclusão deles é que os empresários possuem baixo conhecimento da reforma, confundido, por exemplo, fusão de impostos com corte de impostos. Esse desconhecimento é natural, uma vez que a complexidade da reforma é tão grande que mesmo os especialistas na questão não apresentam consenso sobre a natureza e as consequências das mudanças.
} 
MG), temendo os efeitos da insegurança jurídica da proposta, resolveu determinar nas disposições transitórias da Constituição que o prazo de transição seria de onze anos. A PEC 233/2008 já continha, em sua versão original, o prazo de transição equivalente. O governo observou que era muito custoso reverter uma política já consolidada. Como muitas empresas só se instalaram em determinadas regiões devido aos benefícios fiscais, a reversão desses benefícios provocaria uma fuga de capitais, resultando na criação de cidades fantasma. A minimização desses efeitos passa por longos prazos de transição e compensações do governo central.

Ora, justamente isso retira parte do apelo político da reforma, pois ela se torna cara e de longo prazo de maturação.

\subsection{3 - Pequenos beneficiários do ICMS}

A autonomia estadual em relação ao ICMS não favoreceu apenas as grandes empresas através da guerra fiscal. Houve pequenos beneficiários na indústria e nos serviços. Durante a tramitação da PEC 41/2003, o deputado membro da comissão especial Francisco Dorneles (PP-RJ) lembrou que os incentivos fiscais não são apenas usados para atrair grandes indústrias. Os remédios contra a AIDS também são isentos na maioria dos estados. Muitos deles também não tributam serviço de taxi. Os programas estaduais de apoio à micro e pequena indústria também poderiam ser afetados caso a proposta não tivesse modificações ${ }^{66}$.

Dia 08/07/2003, a comissão especial da PEC 41/2003 recebeu a visita de uma comissão de artistas e representantes do setor cultural, a maioria cariocas. Dentre eles, também estava a secretária de cultura do Rio de Janeiro, que fez uma fala explicando a importância dos incentivos culturais baseados no ICMS. Em apoio ao grupo falaram os deputados Fernando Gabeira (PT-RJ) (situação) e Eduardo Paes (PSDB-RJ) (oposição). Segundo seu discurso, somente o Rio de Janeiro concedia R \$ 25 milhões para a cultura com isenções deste imposto. Atividades esportivas e relacionadas ao turismo também se

\footnotetext{
${ }^{66}$ Discurso disponível em http://imagem.camara.gov.br/internet/audio/Resultado.asp?txtCodigo=00001437
} 
utilizavam de benefícios com o ICMS. Se a reforma, tal como redigida na PEC 41/2003, fosse aprovada, esses benefícios seriam contestados judicialmente.

A partir de casos como esse, pode-se reafirmar a suspeita de que o ICMS acabou gerando uma enorme teia de interesses em volta de si. Ou, dito de outra maneira, a autonomia estadual para manipular este imposto acabou fazendo com que ele se tornasse instrumento de política local para os mais diferentes assuntos.

Diante desse quadro, o relator Virgílio Guimarães tentou substituir a política de incentivos fiscais por recursos orçamentários. Ele criou uma cláusula que faculta aos estados a vinculação de $0,5 \%$ de sua arrecadação para atividades culturais e $0,5 \%$ para atividades socais. Apesar da uniformização do ICMS ter malogrado durante a tramitação da PEC 41/2003, esses dispositivos de fato ingressaram no texto constitucional através da Emenda 42, mostrando que estes setores têm uma força não desprezível.

No caso das pequenas empresas, a Emenda Constitucional 42/2003 previu que elas teriam tratamento diferenciado e privilegiado, segundo lei complementar federal. Isso foi feito na Lei Geral da Micro e Pequena Empresa (Lei Complementar $n^{\circ} 123$, de 2006), que unificou tributos federais, estaduais e municipais. Embora esse tenha sido um ponto que não estava na formulação original da reforma, ele mostra que as questões tributárias não são insolúveis. É claro, desde que atacadas uma a uma.

\subsection{4 - A Multidimensionalidade da unificação do ICMS}

Podemos ver que a ideia de unificar o ICMS é muito simples: o poder de legislar sobre o imposto sai dos governos estaduais e vai para a União. No entanto, as clivagens políticas que em torno da proposta são muito complexas. Os estados são profundamente afetados pela reforma, pois ela altera seus tributos e suas estratégias de desenvolvimento. Os empresários, grandes e pequenos, podem perder isenções. Pequenas políticas estaduais de incentivo podem ser afetadas. A proposta envolve o risco de aumento da carga tributária, o que assusta os pagadores de impostos. O cálculo dos ganhadores e perdedores não pode ser feito, pois depende de decisões futuras. 
Apesar da aparente simplicidade, é muito provável que a multidimensionalidade da unificação do ICMS, apenas ela, já fosse motivo suficiente para inviabilizar a reforma. Mesmo assim, os governos FHC e Lula ainda acreditaram que poderiam aprovar muitas outras medidas polêmicas além desta, como será mostrado abaixo.

\section{5 - Instituição do princípio do destino}

Outro ponto importante da reforma tributária é a instituição do princípio do destino no ICMS. Como se trata de medida fortemente defendida pela literatura técnica, ela acabou sendo proposta nas três reformas tributárias, mesmo que apenas a PEC 233/2008 contasse com esse mecanismo na sua formulação original.

A tributação no destino tem três objetivos. O primeiro é criar mais um instrumento para coibir a guerra fiscal. Como dito acima, o uso do sistema tributário estadual para atrair indústrias só faz sentido quando a tributação é na origem. Se o tributo sobre o consumo for pago aos estados de destino das mercadorias, as isenções beneficiarão os consumidores e não os produtores.

O segundo motivo é que a tributação no destino acaba com algumas distorções provocadas pela tributação na origem. Em geral, quem suporta a carga tributária é o consumidor. Por isso, nada mais justo que seja o estado dele, onde ele pode desfrutar de bens e serviços públicos, que ficasse com os impostos. O sistema de tributação na origem (ainda que "misto" ou "atenuado") transfere renda das regiões mais pobres para as regiões mais industrializadas.

O terceiro motivo para a aplicação do princípio do destino é que o sistema vigente, cobrado parte na origem e parte no destino, tende a dificultar a administração tributária, pois as empresas ficam sob dupla autoridade na transação interestadual. A mera unificação da tributação, seja na origem, seja no destino, ajuda a tornar mais fácil e previsível o processo tributário, inibe a sonegação e auxilia a atividade econômica. Nesse caso, a unificação na origem é mais fácil e eficiente que a unificação no destino, pois a produção é mais concentrada que as vendas a varejo.

Esse último fator, no eantanto, entra em conflito com os outros dois motivos mencionados acima. Para contornar esse fato, houve duas soluções propostas. Na PEC 
175/1995 desenvolveu-se um sistema chamado de "barquinho", onde o governo Federal arrecada o IVA no lugar dos estados nas transações interestaduais, transferindo o recurso para o estado de destino correspondente. Nas reformas 41/2003 e 233/2008 foi proposto um sistema chamado de "travessia", de acordo com o qual os próprios estados arrecadam o tributo integralmente na origem e transferem a parcela referente ao estado de destino por meio de uma câmara de compensação. Assim, seria possível obter as vantagens da tributação no destino e da cobrança na origem.

Como se pode ver, são reformas profundas, que alteram significativamente o funcionamento do ICMS. Elas despertam pelo menos três clivagens políticas.

\subsection{1 - Questão origem/destino (distribuição do imposto).}

Aparentemente, a discussão entre a origem e o destino das mercadorias se resume a uma luta entre exportadores e importadores líquidos na federação, pois o sistema atual beneficia o estado de origem das mercadorias. Porém, a balança comercial interestadual (BCI) não é o único fator que determina se um estado ganha ou perde com o princípio do destino. O cálculo final depende de uma série de fatores, como (1) o tamanho do superávit ou déficit na BCI, (2) se a alíquota interestadual é de $7 \%$ ou $12 \%^{67}$, (3) os estados com que ele transaciona (se têm alíquota de $7 \%$ ou 12\%), (4) a porcentagem das transações interestaduais no total das transações no estado, (5) o tamanho da economia do estado.

Baratto (2006) fez um cálculo hipotético sobre quem ganha e quem perde em uma transição para o destino. Esse cálculo hipotético leva em conta apenas os fatores 1, 2 e 5. Os fatores 3 e 4 não podem ser calculados, pois os estados não possuem ou não divulgam tais informações. Mesmo o Ministério da Fazenda não consegue obter esses números e precisa pedi-los aos próprios estados (que entregam dados de qualidade duvidosa) ${ }^{68}$. O resultado do cálculo de Baratto (2006) chegou à conclusão que ganham com o atual sistema:

\footnotetext{
${ }^{67}$ Um estado moderadamente deficitário, mas com alíquota interestadual de $12 \%$, pode preferir o sistema atual

${ }^{68}$ Segundo Bernard Appy (entrevista realizada em 26/02/2010), os estados têm interesse em divulgar que perderiam recursos com o princípio do destino, pois isso justificaria maiores transferências federais para eles. Quando o Ministério da Fazenda cruzou as previsões divulgadas pelos estados, percebeu-se que a
} 
a) Todos os superavitários na BCI do N/NE/CO+ES (AM, BA, ES, MS)

b) Estados médios do N/NE/CO+ES com equilíbrio comercial na BCI (talvez $\mathrm{GO})$

c) Estados do S/SE-ES com elevados superávits ${ }^{69}$ na BCI (SP, MG, PR)

Perdem com o atual sistema:

a) Estados do N/NE/CO+ES com elevados déficits na BCI (AC, AP, DF, MA, PA, PB,PI, RN, RO e RR).

b) Estados do S/SE-ES deficitários (RJ).

E, finalmente, que a mudança seria mais ou menos neutra nos seguintes estados:

a) Os do N/NE/CO+ES com déficits moderados ${ }^{70}$ na BCI (AL, CE, MT, PE, SE e TO)

b) Os do S/SE-ES com equilíbrio ou superávit moderado (RS, SC)

Como se pode perceber, tal projeção mostra que nem os atores que deveriam racionalmente se posicionar contra a reforma nem os atores que deveriam se posicionar a favor da reforma atingem o patamar de $50 \%$ em nenhuma casas legislativas. Esse cenário poderia mudar se os estados "neutros" se posicionassem a favor da mudança, acreditando que ela simplificaria o sistema, melhoraria sua eficiência econômica e inibiria a sonegação. Mas, mesmo nesse caso, a maioria seria precária, não atingindo o quorum mínimo de 60\%+1 na Câmara dos Deputados.

Como demonstramos no capítulo 2, as pesquisas de Carey e Reinhardt (2003), Arretche (2008) e Cheibub, Figueiredo e Limongi (2009) indicam que não existe uma relação entre o partido do governador e os votos das bancadas estaduais. Porém, isso não quer dizer que um parlamentar aceitaria uma perda grave da arrecadação de seu estado somente porque o governador não é de seu partido. Não é necessário lealdade ao

soma das perdas era muito superior à soma dos ganhos, o que contraria a lógica da transferência para $\mathrm{o}$ destino, segundo a qual perda de um estado corresponde necessariamente ao ganho dos demais.

${ }^{69}$ Baratto (2006) considera um elevado déficit ou superávit um desequilíbrio comercial maior que $50 \%$ da BCI.

${ }^{70}$ Baratto (2006) considera um déficit ou superávit moderado um desequilíbrio comercial equivalente a algo entre $10 \%$ e $50 \%$ da BCI. Desequilíbrios menores que $10 \%$ da BCI são considerados situações de equilíbrio. 


\begin{tabular}{|c|c|c|c|c|c|c|c|c|c|c|c|}
\hline \multicolumn{12}{|c|}{ Tabela XVI - Ganhos e Perdas com a Tributação no Destino } \\
\hline Estados & BCI & $\begin{array}{ll}\text { Alíquota } \\
\text { interestadual }\end{array}$ & $\begin{array}{l}\text { Princípio do } \\
\text { Destino }\end{array}$ & $\begin{array}{l}\mathrm{N} \text { de } \\
\text { Deputados }\end{array}$ & \begin{tabular}{|l|l} 
N de \\
Senadores
\end{tabular} & \begin{tabular}{|l|l|l} 
Deps. a \\
favor
\end{tabular} & $\begin{array}{l}\text { Deps. } \\
\text { contra }\end{array}$ & \begin{tabular}{|l|}
$\begin{array}{l}\text { Deps. a favor } \\
\text { +neutros }\end{array}$ \\
\end{tabular} & $\begin{array}{l}\begin{array}{l}\text { Sens. a } \\
\text { favor }\end{array} \\
\end{array}$ & $\begin{array}{l}\text { Sens. } \\
\text { contra }\end{array}$ & $\begin{array}{l}\begin{array}{l}\text { Sens. contra } \\
\text { tneutros }\end{array} \\
\end{array}$ \\
\hline Acre & Défict elevado & $12 \%$ & ganha & 8 & 3 & 8 & $\overline{0}$ & 8 & 3 & 0 & 3 \\
\hline Alagoas & Déficit moderado & $12 \%$ & neutro & 9 & 3 & 0 & 0 & 9 & 0 & 0 & 3 \\
\hline Amapá & Déficit elevado & $12 \%$ & ganha & 8 & 3 & 8 & 0 & 8 & 3 & 0 & 3 \\
\hline Amazonas & Superávit elevado & $12 \%$ & perde & 8 & 3 & 0 & 8 & 0 & 0 & 3 & 0 \\
\hline$\overline{\text { Bahia }}$ & Superávit moderado & $12 \%$ & perde & 39 & 3 & 0 & 39 & 0 & 0 & 3 & 0 \\
\hline$\overline{\text { Ceará }}$ & Déficit moderado & $12 \%$ & neutro & 22 & 3 & 0 & 0 & 22 & 0 & 0 & 3 \\
\hline Distrito Federal & Déficit elevado & $12 \%$ & ganha & 8 & 3 & 8 & 0 & 8 & 3 & 0 & 3 \\
\hline Espírito Santo & Superávit moderado & $12 \%$ & perde & 10 & 3 & 0 & 10 & 0 & 0 & 3 & 0 \\
\hline Goiás & Déficit moderado & $12 \%$ & perde & 17 & 3 & 0 & 17 & 0 & 0 & 3 & 0 \\
\hline Maranhão & Déficit elevado & $12 \%$ & ganha & 18 & 3 & 18 & $\overline{0}$ & 18 & 3 & 0 & 3 \\
\hline Mato Grosso & Déficit moderado & $12 \%$ & neutro & 8 & 3 & 0 & 0 & 8 & 0 & 0 & 3 \\
\hline Mato Grosso do Sul & Superávit moderado & $12 \%$ & perde & 8 & 3 & 0 & 8 & 0 & 0 & 3 & 0 \\
\hline Minas Gerais & Superávit elevado & $7 \%$ & perde & 53 & 3 & 0 & 53 & 0 & $\overline{0}$ & 3 & 0 \\
\hline Pará & Déficit elevado & $12 \%$ & ganha & 17 & 3 & 17 & 0 & 17 & 3 & 0 & 3 \\
\hline Paraíba & Déficit elevado & $12 \%$ & ganha & 12 & 3 & 12 & 0 & 12 & 3 & 0 & 3 \\
\hline Paraná & Superávit elevado & $7 \%$ & perde & 30 & 3 & 0 & 30 & 0 & 0 & 3 & 0 \\
\hline Pernambuco & Déficit moderado & $12 \%$ & neutro & 25 & 3 & 0 & 0 & 25 & 0 & 0 & 3 \\
\hline Piauí & Déficit elevado & $12 \%$ & ganha & 10 & 3 & 10 & 0 & 10 & 3 & 0 & 3 \\
\hline Rio de Janeiro & Déficit moderado & $7 \%$ & ganha & 46 & 3 & 46 & 0 & 46 & 3 & 0 & 3 \\
\hline Rio Grande do Norte & Déficit elevado & $12 \%$ & ganha & 8 & 3 & 8 & 0 & 8 & 3 & 0 & 3 \\
\hline Rio Grande do Sul & Superávit moderado & $7 \%$ & neutro & 31 & 3 & 0 & 0 & 31 & 0 & 0 & 3 \\
\hline Rondônia & Déficit elevado & $12 \%$ & ganha & 8 & 3 & 8 & 0 & 8 & 3 & 0 & 3 \\
\hline Roraima & Déficit elevado & $12 \%$ & ganha & 8 & 3 & 8 & 0 & 8 & 3 & 0 & 3 \\
\hline Santa Catarina & Superávit moderado & $7 \%$ & neutro & 16 & 3 & 0 & 0 & 16 & 0 & 0 & 3 \\
\hline São Paulo & Superávit elevado & $7 \%$ & perde & 70 & 3 & 0 & 70 & 0 & 0 & 3 & 0 \\
\hline Sergipe & Déficit moderado & $12 \%$ & neutro & 8 & 3 & 0 & 0 & 8 & 0 & 0 & 3 \\
\hline Tocantins & Déficit moderado & $12 \%$ & neutro & 8 & 3 & 0 & 0 & 8 & 0 & 0 & 3 \\
\hline Total & & & & 513 & 81 & 151 & 235 & 278 & 33 & 24 & 57 \\
\hline Total (\%) & & & & $100,0 \%$ & $100,0 \%$ & $29,4 \%$ & $45,8 \%$ & $54,2 \%$ & $40,7 \%$ & $29,6 \%$ & $70,4 \%$ \\
\hline
\end{tabular}


governador para que os parlamentares defendam as rendas de seus estados, basta que eles não queiram ver diminuídos os serviços estaduais, como educação, saúde e segurança. O que une parlamentar e governador nesse caso, mais que a legenda, é a coincidência de interesses. Aliás, deve-se ressaltar que uma perda brusca de receita dos governos estaduais também não é de interesse do presidente.

Também é importante notar que perdas permanentes de arrecadação são difíceis de se compensar com propostas clientelistas, pois os valores envolvidos são muito altos. Para os estados, somente se pode compensar perdas de recursos com aumento de recursos. Ora, isso só é possível, no curto prazo, com aumentos de impostos e transferências do governo central. E no longo prazo, é possível que o aumento da eficiência econômica compense as perdas com o novo modelo.

Todas as propostas propunham prazos de transição e mecanismos de compensação. A PEC 175/1995 previa uma transição de cinco anos, período durante o qual a alíquota interestadual seria reduzida para algo entre $1,75 \%$ e $3 \%$, dependendo do estado. Já a PEC 41/2003 propunha uma transição de onze anos, no fim da qual as alíquotas interestaduais seriam uniformizadas em 4\%. A PEC 233/2008, por sua vez, propunha uma transição de 12 anos, com uma alíquota final única de $2 \%$. As duas primeiras deixavam a compensação das perdas dos estados para lei complementar, o que gerou grande insegurança nos estados envolvidos, enquanto a terceira foi mais prudente - ela criava o "Fundo de Equalização de Receitas", destinado a compensar as perdas dos estados com dinheiro do governo federal.

No entanto, apesar de ser elogiado por parlamentares e governadores, o FER foi questionado pelos estados que estavam tendo ganhos de arrecadação acima da média (São Paulo era um deles). Esses estados tenderiam a perder com a instauração de tal critério, pois ele teria como base a arrecadação de 2006, ajustada de acordo com a inflação e o crescimento do PIB. Assim, os estados reclamaram que a reforma “congelava" a distribuição do imposto, em um momento de crescimento da arrecadação.

Mais uma vez vemos o caráter rígido do sistema tributário. A inconveniência de impor perdas severas e abruptas a determinadas regiões força os negociadores a formular mecanismos de compensação e a deslocar no tempo os efeitos das propostas. Como consequência, o presidente e os governadores não poderiam usufruir dos benefícios da reforma, apesar de terem que arcar com seus custos. 


\title{
5.5.2 - Origem/destino (petróleo e energia)
}

Durante a transição da PEC 41/2003 e 233/2008, houve um engajamento particularmente ativo dos deputados do Rio de Janeiro e de Sergipe. Paraná e Pará também tiveram uma atuação razoável. Os motivos para isto estão no Art. $155, \S^{\circ}$, Inciso I, da Constituição, que diz que o petróleo e a energia serão cobrados exclusivamente no destino. Esses estados, grandes produtores de petróleo e energia elétrica, viram a reforma como uma forma de conseguir políticas distributivas, propondo que o ICMS sobre tais bens passasse a ser parcialmente cobrado na origem, da mesma forma que os demais. Trata-se de uma medida que apresenta ganhos concentrados para os estados produtores de petróleo e energia e, ao mesmo tempo, custos difusos para toda a economia nacional.

Durante a tramitação da $P E C 41 / 2003$, dia 12/06/2003, a reunião que discutia a proposta foi "invadida" pelos governadores Rosinha Garotinho (PSB-RJ), Wilma Faria (PSB-RN) e João Alves (PFL-SE), que vieram à comissão sem serem convidados. Os governadores fizeram discursos conclamando os deputados a acabar com a "discriminação" que os estados produtores de petróleo sofrem. Os dois coordenadores da frente pela mudança da tributação do petróleo foram Eduardo Paes (PSDB-RJ) e Machado (PFL-SE). Eles conseguiram que o governador João Alves voltasse mais uma vez para a comissão, desta vez a convite, em uma das duas únicas audiências públicas realizadas. Nela, o deputado Heleno Silva (PL-SE) chegou a fazer uma fala agressiva neste sentido:

\begin{abstract}
Antes de levarmos essa matéria ao Plenário, é bom discutirmos o assunto com as bancadas do Rio de Janeiro, do Rio Grande do Norte, do Paraná e do Espírito Santo, os produtores de petróleo e de energia. (...) Chamo a atenção da bancada aliada do Relator para que, juntos, discutamos o assunto, porque na hora da votação, não vai ter base aliada não, cada um vai defender seu povo, sua Região." ${ }^{11}$
\end{abstract}

A questão voltou de forma ainda mais acentuada na PEC 233/2008. O relator da proposta na Comissão de Constituição e Justiça, Dep. Leonardo Picciani (PMDB-RJ),

\footnotetext{
${ }^{71}$ Notas taquigráficas, 08/07/2003

http://www2.camara.gov.br/comissoes/temporarias/especial/encerradas/pec04103/notas/Pec04103nt08070 $\underline{3 . p d f}$
} 
alterou a proposta do governo, determinando que o petróleo e a energia deveriam ser tributados parcialmente na origem, da mesma forma que os demais produtos. Ele argumentou que o referido artigo da Constituição era inconstitucional ${ }^{72}$ e feria o princípio da isonomia. O governo não conseguiu dissuadir o deputado a mudar seu relatório e ele acabou sendo aprovado.

Apesar de a literatura técnica defender que todos os produtos deveriam ser tributados no destino, os estados produtores de petróleo e energia conseguiram, nas PECs $41 / 2003$ e 233/2008, retirar a tributação completamente no destino para estes produtos. Isso em parte foi compensado pela redução da alíquota interestadual, que diminui a parte do ICMS de direito do estado de origem. Por outro lado, São Paulo, que já teria muitas perdas com o princípio do destino, seria ainda mais prejudicado por essa proposta.

Temos aqui, então, mais uma clivagem regional que aumenta as dimensões da reforma. A diferença neste caso, entretanto, é que ela tem estrutura inversa da anterior, pois têm custos difusos e benefícios concentrados.

\subsection{3 - Questão origem/ destino (cobrança do imposto).}

Outra questão que apareceu nas três propostas é a mudança do sistema de recolhimento do imposto. Elas propunham que o ICMS sobre transações interestaduais deixasse de ser cobrado nas barreiras fiscais nas estradas e passasse a ser cobrado na origem das mercadorias. É importante não confundir a distribuição do imposto com a sua cobrança. O princípio do destino prescreve que ao estado no qual o produto é consumido cabe o direito de receber o imposto. No entanto, isso não tem relação necessária com o momento em que o imposto é cobrado. O imposto pode ser cobrado na porta da fábrica (ou seja, na origem) e ser posteriormente repassado ao estado de destino. Como dito acima, essa é uma das poucas vantagens da tributação na origem: a possibilidade de centralizar a cobrança nos núcleos de produção.

As três PECs analisadas (na versão original ou na versão do relator) acabaram por propor o mesmo mecanismo: a alíquota interestadual não seria reduzida a zero, mas

\footnotetext{
${ }^{72}$ Essa é uma interpretação extremamente singular, pois o direito brasileiro não aceita a tese dos artigos constitucionais inconstitucionais. O STF reconhece a Constituição como um todo harmônico sem hierarquia interna.
} 
sim a um valor muito pequeno. Isso criaria incentivos para que o governo do estado de origem fiscalizasse eficazmente os seus contribuintes, já que ele receberia uma parte (bem menor que a atual) do imposto na origem.

Na PEC 175/1995 foi criado um sistema chamado de "barquinho", proposto pelo técnico do IPEA Ricardo Varsano (Varsano, 1995 e 1999). Como a proposta cria um IVA dual, administrado conjuntamente por estados e União, a Receita Federal iria controlar a distribuição dos recursos entre as unidades da federação. Em transações interestaduais a alíquota da parte estadual do IVA seria reduzida a zero e a alíquota federal subiria na parcela correspondente. Posteriormente o governo federal transferiria aos estados as parcelas correspondentes do imposto. Este sistema foi severamente criticado pela Secretaria da Receita Federal, pois deixava para o governo federal a compensação dos créditos dos impostos estaduais. Segundo Ministério da Fazenda (1999) :

O modelo do IVA dual é tecnicamente frágil e introduz no sistema brasileiro dificuldades administrativas incontornáveis. $O$ mecanismo adotado pelo modelo (redução a zero da alíquota estadual nas operações interestaduais e seu acréscimo à alíquota federal) gera um acúmulo inadministrável de créditos e débitos, sem apresentar soluções operacionais que sejam viáveis. O argumento de que acúmulo de crédito é algo comum em qualquer IVA do mundo, sendo resolvido mediante ressarcimento, é enganoso, pois os modelos de IVA atualmente em vigor geram créditos, como exceção à regra geral, quase sempre na exportação.

A Secretaria da Receita Federal também questionou a possibilidade desses créditos serem ressarcidos pelo abatimento de outros impostos federais, como o Imposto de Renda e as contribuições sociais. Com isso, o setor privado reduziria a possibilidade de acumular créditos não compensados, enquanto a receita dos impostos se reverteria fortemente para os estados, prejudicando o orçamento geral da União e o orçamento da seguridade social. O Ministério da Fazenda argumentou que o mais provável nessa situação é que os créditos do imposto simplesmente não seriam entregues às empresas, jogando o custo da proposta para o setor privado.

As PECs 41/2001 e 233/2008 abandonaram a proposta do IVA dual e do modelo "barquinho". Em seu lugar, elas propuseram um sistema no qual o ICMS teria uma legislação única, mas continuaria sob administração exclusiva dos estados. Para poder possibilitar a cobrança do imposto na origem, seria necessário instituir uma câmara de compensação dos tributos - o chamado modelo "travessia". O contribuinte não teria que 
pagar o equivalente à alíquota interestadual na origem e, posteriormente, a diferença no destino. O tributo inteiro seria cobrado na origem e depois repassado ao estado de destino pela câmara de compensação. Isso acabaria com a dupla autoridade tributária na transação estadual, diminuiria as possibilidades de fraude e desburocratizaria o trabalho das empresas. De modo geral, ainda, a medida diminuiria a necessidade das barreiras fiscais nas estradas, minimizando a grande parafernália burocrática que os fiscos estaduais criaram para coibir a sonegação.

Esta é uma profunda mudança no funcionamento do ICMS, com sérias consequências sobre sua administração. O sistema teria regulamentos uniformes estabelecido por convênio do Confaz. Para garantir o respeito às regras do modelo travessia, as reformas prescreviam que o estado que retivesse parcela correspondente à outra unidade da federação poderia sofrer intervenção federal e retenção do Fundo de Participação dos Estados, bem como das transferências voluntárias. Durante os três primeiros anos, o governo federal seria o administrador da câmara de compensação. Ou seja, a necessidade de enforcement do novo sistema aumentava o poder do governo federal de intervir nos Estados, o que é natural, dada a necessidade de garantir a uniformidade e credibilidade do novo sistema. Por consequiência, o sindicato dos fiscais estaduais emitiu uma nota crítica à proposta, argumentado que ela constituía um atentado ao federalismo (Fenafisco, 2008).

A alteração no sistema de cobrança do ICMS requer mudanças na administração tributária, com novas estruturas e novo treinamento da máquina de arrecadação. $\mathrm{O}$ marco legal, os regulamentos infralegais e a jurisprudência precisariam ser alterados. Um sistema como esse é inédito no mundo ${ }^{73}$. E o pioneirismo tem seus riscos. No curto prazo, os efeitos da proposta poderiam resultar no inverso dos esperados. Problemas decorrentes da descontinuidade administrativa poderiam provocar diminuição da eficiência da arrecadação e aumento da evasão devido às reações imprevisíveis nos contribuintes e nas máquinas fiscais.

Eis aqui um dos motivos por que as reformas tributárias no mundo todo tendem a ser incrementais. As burocracias tributárias consumam repetir o bordão : “imposto bom é imposto velho". Esse é um ponto menos visível da reforma, pois envolve detalhes administrativos. Durante a tramitação da PEC 41/2003 somente os parlamentares com

\footnotetext{
${ }^{73}$ É preciso lembrar que o Brasil é o único país do mundo onde o IVA é de responsabilidade das autoridades subnacionais. Para uma análise técnica das diferentes formas de se compatibilizar a tributação na origem com o princípio do destino, ver Forum Fiscal dos Estados (2006) .
} 
perfil mais técnico, como o relator Virgílio Guimarães e os deputados Mussa Demes e Luiz Carlos Hauly (PSDB-PR), mencionaram dificuldade a ele relacionadas. Contudo, esse é sim um ponto onde a complexidade técnica criou entraves à proposta. Ou seja, com sua inclusão na proposta, acrescentou-se-lhe mais uma dimensão: a da técnica da administração tributária.

\section{6 - ICMS municipal}

As propostas também alteram a distribuição do ICMS para os municípios. A Constituição determina que os estados devem repassar $25 \%$ da arrecadação do imposto para os municípios, sendo que $75 \%$ da distribuição seria segundo "valor adicionado nas operações sujeitas ao imposto", ou seja, segundo a contribuição que o município dá para o ICMS total do estado. O critério vigente do imposto faz com que cidades pequenas com grandes indústrias recebam um percentual muito maior que as cidades menos industrializadas. A PEC 41/2003 acabava com tal determinação, facultando às leis complementares federais os critérios de distribuição do imposto. Assim, a supressão do referido inciso da Constituição abriria espaço para um critério mais equânime na distribuição do ICMS municipal. Uma alternativa defendida pelo governo Lula em 2003 era que a nova distribuição seria inversamente proporcional à renda e proporcional à população do município. Essa proposta era apoiada pelo presidente da Confederação Nacional dos Municípios, Paulo Ziulkoski.

A PEC 233/2008, por sua vez, propunha outro mecanismo para acabar com a distorção. Estabelecia-se um "teto" para a distribuição per capta do ICMS municipal. Nenhum município poderia receber um valor igual a quatro vezes a sua participação na população do estado. O mecanismo de transição seria, assim, gradual, pois os municípios não poderiam perder receitas de um ano para outro, critério também incluído pelo relator na $P E C 41 / 2003$.

Esse é um exemplo típico da política com custos concentrados e ganhos difusos. A tributação segundo o montante de tributo gerado no município produziu uma série de ganhos concentrados em algumas cidades, como Campos - RJ, São Caetano do Sul - SP e Paulínia - SP. Haveria o perigo de tais cidades terem uma perda brusca de receita. Nos estados mais pobres também existe o problema das capitais. Apesar de elas não terem uma receita per capta tão grande quanto os "paraísos tributários" mencionados acima, 
elas concentram a maior parte do ICMS de seus estados.

Dado o critério claramente injusto da distribuição da cota-parte do ICMS, a proposta é extremamente pertinente,. Porém, ela ficou presa entre outras muitas clivagens. Assim, não há como não se perguntar se era realmente necessário colocar essa proposta na reforma, já que se estava tratando de tantos outros assuntos complexos e difíceis. O resultado é que essa norma, claramente injusta, continua na Constituição, pois ela só é discutida no bolo da reforma. Note-se que apesar de a proposta ter custos concentrados e benefícios difusos, o peso político dos paraísos tributários é pequeno, dada a exiguidade de suas populações. No caso das capitais, o critério encontrado na PEC 233/2008 parece evitar as perdas de receita dos municípios.

\section{7 - Aumento da progressividade dos tributos}

Além de alterar as regras do ICMS, as propostas também propunham tornar o sistema tributário mais redistributivo. Nesse ponto, os governos resolveram não apenas alterar os impostos como também alterar as vinculações das contribuições sociais.

As três PECs propunham a redução dos impostos para alimentos. Essa medida foi muito defendida pela esquerda ${ }^{74}$, mas sofreu oposição dos estados pobres e agrícolas. Os estados agrícolas se opuseram porque concentram a tributação na origem e, portanto, uma desoneração lhes traria perdas concentradas. Os estados pobres se opuseram porque não possuem muitas bases tributáveis e, por isto, oneram o consumo da classe baixa. Conforme mostra Vianna et alli (2000), os estados mais pobres possuem uma tributação mais regressiva do que os estados mais ricos.

A PEC 175/1995 instituía a progressividade do IPTU. A PEC 41/2003 determinava que a CSLL do setor financeiro não poderia ser menor do que a de nenhum outro setor. Tanto a proposta de 1995 quanto a de 2003 instituíam a progressividade do imposto de herança (ITCM), do imposto de transmissão de bens intervivos (ITBI) e facilitavam a aprovação do Imposto sobre Grandes Fortunas, facultando sua regulamentação por lei ordinária e não por lei complementar.

Essas medidas vão ao encontro da proposta de reforma tributária da bancada do PT, lançada no final da década de 90. Ela propunha uma visão diferente das reformas

\footnotetext{
${ }^{74}$ Entrevista com Bernard Appy, 26/02/2010.
} 
analisadas aqui. Ao invés de privilegiar o fortalecimento dos tributos sobre o consumo, ela defendia o aumento da progressividade dos tributos sobre a renda e sobre o patrimônio, bem como o aumento do poder de fiscalização das burocracias tributárias. Assim se poderia aliviar a tributação do trabalho, produção e consumo (Rangel \& Medeiros Netto, 2003, p. 12).

O aumento da progressividade, diferentemente das propostas anteriores, possui uma clivagem esquerda/direita. Isso leva a outras dimensões para serem negociadas na reforma: a luta ideológica e de classes sociais. Os conflitos aqui não seguem critérios regionais, mas partidários. A isso se acrescenta algumas clássicas considerações sobre a dificuldade de democracias aprovarem aumentos de impostos em tempos de paz. A resistência ao aumento de impostos costuma ser grande. Segundo Marcus Melo (2005) a aceitação da taxação depende de muitos fatores, inclusive a percepção do retorno por parte do Estado, na forma de serviços públicos (tax morale). Também se deve considerar que as perdas são concentradas nas classes média e alta e os ganhos são difusos por toda a sociedade. Mais uma vez, portanto, é de se ressaltar a imensa complexidade das propostas de reformas.

Um ponto merece destaque: o governo conseguiu aprovar em 2000 a Emenda 29, que estabelecia a progressividade do IPTU, de forma idêntica ao que propunha a PEC 175/1995. Assim, novamente vemos que não é o campo tributário como um todo que sofre de crônica paralisia; apenas as grandes reformas estruturais é que falham.

\section{8 - Reformulação das vinculações constitucionais}

O principal nó crítico da reforma dos tributos federais é o complicado sistema de vinculações orçamentárias do Brasil. Existem vinculações verticais e horizontais. As verticais são aquelas que transferem recursos aos estados e municípios. Por esse princípio, $47 \%$ da arrecadação do Imposto de Renda e do Imposto sobre Produtos Industrializados devem ser distribuídos através do FPE e do FPM. Também 20\% de qualquer imposto que a União vir a criar deve ser repartido com os estados. As vinculações horizontais são aquelas que atrelam determinado tributo a determinado gasto. As contribuições sociais são exemplos de vinculações horizontais. Apesar de terem caráter tributário (são compulsórias e não vinculadas a um benefício para $o$ pagador), elas gozam de prerrogativas especiais, como, por exemplo, não se 
submeterem ao princípio da anterioridade e, principalmente, não precisarem ser repartidas com os governos subnacionais. Por outro lado, elas estão vinculadas aos gastos sociais: saúde, assistência social e previdência. Existe também uma contribuição que é destinada à educação básica: o salário educação, que é cobrado sobre a folha de pagamento das empresas. O PIS/PASEP também têm vinculações destinadas a programas do Ministério do Trabalho (seguro desemprego, FAT, abono salarial) e ao BNDES.

As vinculações criam distorções no sistema. Os atores que têm benefícios concentrados com as vinculações criam grupos de pressão para aumentar os impostos vinculados. Desse modo, a autoridade política perde liberdade para fazer política tributária. O Ministério do Trabalho e o BNDES resistem ao corte do PIS/PASEP e lutam pelo seu aumento. O Ministério da Educação luta para manter o Salário Educação. Os estados e municípios lutam para impedir cortes no IPI e no IR. Todo o setor social luta para manter e ampliar todas as contribuições sociais.

No período pós-1988, a União se dedicou a ampliar sua receita através das contribuições sociais. Apesar de os impostos também terem ampliado sua arrecadação, principalmente devido à melhor fiscalização, o governo federal não investiu recursos políticos para ampliar suas alíquotas. Ao contrário, ele as reduziu, como no caso do Imposto de Renda. O motivo para isso é obvio. A criação de impostos em tempo de paz é uma medida impopular para qualquer governo. Como os impostos são divididos com os entes federados, a relação entre os custos e os benefícios fica desfavorável. Já no caso das desonerações dá-se o contrário. É muito melhor para o governo desonerar impostos do que contribuições, pois metade do "prejuízo" fica com estados e municípios, sendo que o bônus políticos ficam com o Presidente.

As consequências dessas políticas foram uma piora da qualidade do sistema tributário, pois (1) se aumentou ainda mais o peso dos tributos indiretos, (2) muitas contribuições produzem efeitos em cascata, (3) as contribuições possuem as mesmas bases dos impostos, gerando multiplicidade de impostos sobre o mesmo fato gerador e (4) houve uma piora das relações federativas, pois a União aumentava sua arrecadação enquanto os estados e municípios mentiam seus níveis de tributos. 
Diante desses fatos, as PEC 175/1995 e 233/2008 resolveram reformar também os tributos nacionais, unificando PIS/PASEP, COFINS e Salário-Educação em um Imposto sobre Valor Agregado. No caso da PEC 175/1995, também se unificou o IPI ${ }^{75}$.

A reforma de 1995 previa a parcela do IVA federal que superar 25\% do IVA estadual seria destinada à seguridade social. Foram criadas subvinculações ao orçamento da seguridade social para sustentar os programas do Ministério do trabalho e os gastos com educação básica. A reforma também acabava com a obrigação da União dividir com os estados os impostos criados pela competência residual.

A PEC 233/2008 foi mais incisiva. Ela propunha uma alteração drástica no funcionamento do orçamento federal. Não haveria mais contribuições sociais sobre faturamento, receita, lucro ou consumo. O orçamento da seguridade social seria financiado pelas contribuições sobre folha de salários e por 39,7\% do IR, IPI e IVA-F. Além disso, ela desonerava em $6 \%$ as contribuições patronais ao INSS em sete anos. A proposta tinha a vantagem de fazer com que os Fundos de Participação fossem distribuídos por uma base mais ampla de recursos e de possibilitar a substituição de tributos indiretos por tributos diretos. Pela nova proposta, a União poderia desonerar a produção e o consumo e onerar a renda sem perder recursos e sem mexer nos orçamentos sociais e subnacionais.

Porém, a reforma encontrou uma resistência que era ao mesmo tempo pragmática e ideológica. Os setores ligados à saúde, a assistência social e aos sindicatos de trabalhadores criticaram a proposta como um ataque ao orçamento da seguridade social. Eles não queriam ver desmontado o sistema social criado em 1988, que consideraram uma vitória.

Em 15 de abril de 2009, cerca de sessenta entidades sociais entregaram ao presidente da Câmara dos Deputados, Michel Temer (PMDB-SP), um documento intitulado "Manifesto em Defesa dos Direitos Sociais Básicos sob Ameaça na Reforma Tributária". Dentre essas entidades estava a Confederação Nacional dos Bispos do Brasil (CNBB), o Movimentos dos Trabalhadores Rurais Sem-Terra (MST), a Confederação dos Trabalhadores na Agricultura (CONTAG), a Associação Brasileira Organizações Não Governamentais (ABONG), o Conselho Nacional de Saúde, o Conselho Federal de Serviço Social, Conselho Nacional dos Secretários de Saúde, o

\footnotetext{
${ }^{75}$ Segundo Bernard Appy, o governo resolveu preservar o IPI para poder fazer política industrial. Seu fim seria danoso para algumas regiões, como a Zona Franca de Manaus (palestra proferida no Cebrap em 25/04/2008).
} 
Conselho Nacional de Secretários Municipais de Saúde, o Conselho Nacional de Secretários de Educação, a União Nacional dos Dirigentes Municipais de Educação e seis centrais sindicais (incluindo as duas maiores, CUT e Força Sindical). No documento, as entidades argumentam que:

O projeto de reforma, sob o manto da simplificação tributária, extingue as contribuições sociais e incorpora esses recursos a impostos. A Seguridade Social perderia essas fontes vinculadas e de uso exclusivo, em troca da receita de uma fração da arrecadação desses novos impostos. Assim, as políticas sociais deixariam de contar com recursos exclusivos e passariam a disputar no bolo do orçamento fiscal recursos com os governadores $e$ prefeitos, Forças Armadas e dos Poderes, enfrentando ainda forte pressão de setores empresariais pelo aumento dos gastos com investimentos em infraestrutura ou por maior desoneração tributária. (Entidades Sociais, 2009)

Para esses atores, o sistema de tributos vinculados é garantia de permanência dos recursos sociais. Os argumentos de Appy e Mabel de que a reforma mantém os gastos sociais e apenas reformula os vínculos não convenceu esses atores, que temeram os efeitos do "risco moral" envolvido na alteração ${ }^{76}$.

E mesmo a desoneração da folha de pagamentos e o fim da CSLL foi duramente criticado pela entidades:

Há outros efeitos da reforma igualmente prejudiciais: no que se refere à desoneração da folha de salários, por meio da redução da contribuição patronal para a Previdência Social, estimativas do Ministério da Fazenda indicam perda de cerca de $R \$ 24$ bilhões nas receitas previdenciárias. Mesmo que o Orçamento da União supra essa perda, isso certamente fortalecerá o falso argumento de "déficit da Previdência". Ocorre ainda a diminuição da tributação sobre o lucro dos bancos, que não estarão mais submetidos às alíquotas da contribuição sobre o lucro, maiores para o setor financeiro - o projeto incorpora essa contribuição ao imposto de renda, que não admite diferenciação por setor econômico. (Entidades Sociais, 2009)

Como se pode observar, a idéia de reformular o sistema de vinculações federais criou mais uma clivagem na reforma. Houve o temor dos setores sociais de que haveria cortes de recursos para as áreas sociais. Mais uma vez vale dizer: não há nenhuma evidência de que não seja possível impor perdas ao setor social. Isso foi feito várias vezes, como por exemplo na aprovação do Fundo Social de Emergência, em 1994, que

\footnotetext{
${ }^{76}$ Um interessante relato dos "apuros" que passaram Bernard Appy e Sandro Mabel em uma audiência pública na Comissão se Seguridade Social e Família da Câmara dos Deputados pode ser visto em (Udovic, 2009)
} 
desvinculou $20 \%$ dos recursos do orçamento da seguridade social. Tal mecanismo, que era para ser temporário, continua em vigor, pois sofreu sucessivas prorrogações. Ele se acabou se transformando na Desvinculação das Receitas da União (DRU), cuja prorrogação era uma das propostas da PEC 41/2003, uma das poucas que foram aprovadas. A "vitória” do setor social na PEC 233/2008 foi possível porque ele pôde se aliar aos governadores, prefeitos, empresários e burocratas para formar uma ampla coalizão de veto à reforma.

\section{9 - As Reformas Incrementais}

A discussão acima pode fazer crer que o problema tributário não tem solução, pois toda reforma tende à paralisia. Mas não é isso o que ocorre. Houve muitas mudanças constitucionais no sistema tributário desde 1988. A começar com a Emenda 3, que instituiu o imposto sobre transações financeiras, a substituição tributária, extinguiu o imposto municipal sobre combustíveis e o adicional estadual ao imposto de renda. No caso, foi possível chegar a tal resoltado porque a reforma era menos abrangente do que a proposta pelas PECs 175/1995, 41/2003 e 233/2008.

Não se trata de um exemplo isolado. O governo Fernando Henrique Cardoso foi muito ativo no campo fiscal, mas optou por agir de forma incremental. Em 1995 e 1996 ele aprovou as "três leis Kandir" - nome dado em referência ao relator e grande articulador das reformas, o deputado Antônio Kandir (PSDB-SP). As duas primeiras (leis 0913/1995 e 1236/1995) reformularam o imposto de renda. Eliminou-se a correção monetária, instrumento criado durante a época de alta inflação, que tornava o sistema de imposto de renda extremamente complexo. Também se determinou um tratamento isonômico entre residentes e não residentes, tributando as empresas não só pelos resultados financeiros obtidos internamente, mas também pelos resultados off-shore. Por outro lado, essa reforma isentou os dividendos distribuídos aos acionistas (alegando que isto seria bitributação com relação à tributação do lucro) e se diminuiu a alíquota máxima do imposto de renda de $43 \%$ para $25 \%$ (posteriormente aumentada para $27,5 \%$ ), e a alíquota mínima de $25 \%$ para $15 \%$. Essas mudanças fizeram com que o Secretário da Receita Federal, Everardo Maciel, declarasse orgulho em um seminário sobre a Reforma tributária na Bahia: 
Na verdade, a nossa legislação do Imposto de Renda Pessoa Jurídica está no nível de qualquer país do Primeiro Mundo (FIEB, 2000, p. 19).

A terceira lei (Lei Complementar 87 de 1996, a única que ficou conhecida sob a alcunha de Lei Kandir), reformava a legislação do ICMS. Ela propunha duas medidas simples: (a) isentava a exportação dos produtos primários e semielaborados e (2) dava o direito de as empresas obterem créditos com a compra de bens que se incorporavam no ativo fixo.

Essas propostas sofreram pressões de dois tipos. O primeiro veio dos estados exportadores de produtos primários. Os estados agrícolas do Centro-Oeste e os mineradores do norte argumentaram que a medida traria uma perda irreparável para suas finanças. Como muitos deles são estados pobres, eles não podem substituir a tributação do comércio exterior por fontes internas, pois seu consumo é baixo. Para sanar este problema, Kandir criou um fundo de ressarcimento, onde se aplicava uma complexa fórmula para auferir a perda de arrecadação decorrentes da medida. Esse fundo, que era para ser temporário, foi renovado sucessivas vezes pelo parlamento. Com o tempo, deixou de ter relação com as exportações e passou possibilitar uma simples redistribuição de renda aos estados mais pobres. A segunda crítica veio dos estados industrializados, que teriam perdas com a desoneração dos bens de capital. A compensação, nesse caso, veio com a determinação de que os créditos do ativo fixo somente seriam aproveitados no prazo mínimo de quarenta e oito meses, o que retirou grande parte dos ganhos econômicos que a reforma poderia obter. A reforma 233/2008 acabava com este mecanismo, instituindo o aproveitamento imediato dos créditos do ativo fixo. Como a reforma falhou por inteiro, esse mecanismo, fundamental para a ampliação dos investimentos das empresas, também falhou.

As Leis Kandir foram as principais alterações no sistema tributário do período analisado. Contrariam a noção de que o governo Fernando Henrique teve uma postura apenas obstrutiva. Nenhuma medida teve o título redentor de "reforma tributária", pois elas eram pontuais e tópicas. Mas, ao contrário das reformas estruturais, elas foram aprovadas. 
Mais do que isto, a reforma iniciada na Lei Kandir (a do ICMS) acabou por facilitar a aprovação de outras reformas. A PEC 41/2003 propunha que o mecanismo de desoneração das exportações fosse para o texto constitucional. O dilema se repetiu, pois os estados exportadores reclamaram que a proposta não constitucionalizava o fundo de compensação da Lei Kandir. Os estados do Norte - notadamente o Pará - reclamaram que a proposta criaria uma insegurança quando à sua arrecadação futura, afinal a Lei Kandir impediu que eles taxassem as únicas grandes atividades econômicas de suas regiões: a mineração, a madeira, a pecuária e a agricultura de exportação. Por isso, eles reivindicaram que o fundo de compensação também entrasse na Constituição.

Diante desses problemas, os negociadores da PEC 41/2003 resolveram incorporar tanto a desoneração das exportações, quanto um mecanismo de compensação para os estados. O fundo de compensação continuaria sendo decidido pela negociação política durante a elaboração do orçamento. Esse foi um dos poucos pontos vitoriosos da PEC 41/2003. Os motivos dessa "vitória" parecem ser simples: a proposta não altera o status quo, apenas o consolida. Quando chegou a PEC 233/2008, já não se considerava esse ponto uma questão, e ele ficou de fora da proposta.

Outro ponto que merece destaque se refere aos tributos municipais. A PEC 175/1995 permitia a progressividade do IPTU, tanto em razão do valor do imóvel, quanto "sua progressividade do tempo", para motivos de planejamento urbano. A progressividade no tempo já constava na Constituição, mas não do capítulo tributário e sim no capítulo da Política Urbana (Art. 182, §4) e apenas para terrenos não edificados ou subutilizados. Como a PEC 175/1995 falhou, não foi possível aprovar a progressividade do IPTU através dela (no Brasil, há poucos impostos progressivos sobre a propriedade). Porém, a medida foi aprovada na Emenda 29/2000 exatamente como constava na PEC 175. A razão para isso também parece ser simples: a Emenda 29 possui apenas 966 palavras, altera sete artigos e vinte e sete itens da constituição. Ou seja, é bem mais sucinta do que as reformas tributárias. Além disso, a análise de sua estrutura interna mostra que ela tinha poucas clivagens: 


\begin{tabular}{|l|c|c|}
\hline \multicolumn{3}{|c|}{ Tabela XVII - Análise EC 29-2000 } \\
\hline Proposta: & Ganhadores & Perdedores \\
\hline $\begin{array}{l}\text { Ampliação e vinculação dos recursos para a } \\
\text { saúde }\end{array}$ & Setor da saúde & $\begin{array}{c}\text { União, Estados e } \\
\text { Municípios }\end{array}$ \\
\hline IPTU progressivo & Municípios & $\begin{array}{c}\text { Grandes proprietários } \\
\text { de imóveis urbanos. }\end{array}$ \\
\hline
\end{tabular}

A principal proposta da emenda era vincular os recursos para a saúde, por isso contou com o apoio entusiasta da bancada do setor ${ }^{77}$. Para se compensar os municípios, permitiu-se o IPTU progressivo. A proposta era simples. Por isso pôde ser negociada.

A história se repetiu na Emenda 37 de 2002. Essa emenda tinha as seguintes propostas: (a) regulação dos pagamentos dos precatórios, (b) prorrogação da CPMF até 31 de dezembro de 2004 e (c) impedir a guerra fiscal do ISS através de leis nacionais e uma alíquota mínima. Essa última proposta também foi extraída das PECs 175/1995 e $383 / 2001$.

\begin{tabular}{|l|c|c|}
\hline \multicolumn{3}{|c|}{ Tabela XVIII - Análise EC 37-2002 } \\
\hline Proposta & Ganhadores & Perdedores \\
\hline Regulações sobre os precatórios & Credores & Estados e Municípios \\
\hline Prorrogação da CPMF & União & Contribuintes \\
\hline Regulação do ISS & $\begin{array}{c}\text { Municípios (principalmente os } \\
\text { grandes) }\end{array}$ & Serviços \\
\hline
\end{tabular}

Por fim, os municípios tiveram nova vitória com a Emenda 39 de 2002. Essa reforma que possui oitenta palavras e altera um artigo e um item da Constituição, permite aos municípios estabelecer taxas sobre a energia elétrica para custear o serviço de iluminação pública.

O governo Fernando Henrique Cardoso também resgatou algumas propostas da PEC 175 na Emenda 33 de 2001. Essa reforma tinha 779 palavras, alterava três artigos e vinte e nove itens. Instituía-se o princípio do destino na CIDE, permitia-se que os estados e municípios criassem contribuição sobre seus funcionários, eliminava-se brechas na cobrança de ICMS nos importados, instituía-se o imposto monofásico sobre os combustíveis e criava-se a CIDE-Combustíveis. A CIDE-Combustíveis acabou se tornando um imposto muito bem avaliado e alguns deputados criticaram a proposta de

\footnotetext{
${ }^{77}$ Até o momento em que este trabalho foi escrito, em novembro de 2010, a emenda ainda não havia sido regulamentada.
} 
seu fim na comissão especial da PEC 233/2008. Eles argumentaram que sua contribuição havia instituído uma fonte segura e estável para os projetos de infraestrutura em transportes.

\begin{tabular}{|l|c|c|}
\hline \multicolumn{2}{|c|}{ Tabela XIX - Análise EC 33-2001 } \\
\hline $\begin{array}{l}\text { Proposta } \\
\text { Institui a CIDE sobre importados e a isenta para a } \\
\text { exportação }\end{array}$ & Indústria nacional & Difuso \\
\hline $\begin{array}{l}\text { Previdência dos Servidores Públicos } \\
\text { (permite a criação de contribuições para a } \\
\text { manutenção dos fundos de previdência estaduais e } \\
\text { municipais). }\end{array}$ & Estados, municípios & Servidores \\
\hline $\begin{array}{l}\text { Fortalecimento do ICMS sobre produtos } \\
\text { importados }\end{array}$ & Estados & Difuso \\
\hline $\begin{array}{l}\text { Permite que o ICMS sobre combustíveis seja } \\
\text { monofásico }\end{array}$ & Estados & Difuso \\
\hline $\begin{array}{l}\text { Criação da CIDE-Combustíveis } \\
\text { (o imposto será destinado a subsídios ao álcool, } \\
\text { projetos ambientais e infraestrutura de } \\
\text { transportes) }\end{array}$ & $\begin{array}{l}\text { Sucroalcooleiro e de } \\
\text { infraestrutura de } \\
\text { transportes }\end{array}$ & $\begin{array}{c}\text { Setor dos } \\
\text { combustíveis }\end{array}$ \\
\hline
\end{tabular}

Como se pode ver, a EC 33 tinha ganhadores concentrados. Mas os perdedores eram relativamente difusos. A exceção foram os funcionários públicos estaduais e municipais, que viram o ponto que lhes era mais desfavorável na PEC 175/1995 ser aprovado. O setor dos combustíveis teve perdas, mas elas não foram muito consideráveis. Os combustíveis possuem uma demanda pouco elástica. Portanto, quem arcou com a maior parte das perdas foram os consumidores.

Por fim, analisaremos a última reforma constitucional incremental no setor tributário: a Emenda 42, oriunda da PEC 41/2003. Como foi dito anteriormente, a reforma de 2003 foi desmembrada no Senado Federal, sendo reduzida à menos da metade da versão aprovada na Câmara dos Deputados. Mas seria interessante observar o que foi aprovado.

A tabela XX mostra as propostas da Emenda 42. Ela possui 1945 palavras, alterou vinte e três artigos da Constituição e quartenta e cinco itens. Repare que quase todas as propostas possuem custos difusos e benefícios concentrados (propostas clientelistas, segundo Wilson). São exemplos disso os recursos vinculados e prioritários para as burocracias tributárias e o princípio da noventena. O Senado passou a ter como 
atribuição avaliar o Sistema Tributário Nacional. Também se permitiu alíquotas diferenciadas dos tributos federais para fins de política comercial ou industrial. Instituiu-se contribuições sociais sobre os importados e sua isenção sobre os exportados (princípio do destino no comércio internacional). Prescreveu-se tratamento privilegiado às pequenas empresas. Isentou-se de ICMS as rádios e TVs de transmissão gratuitas. Abriu-se a possibilidade dos estados vincularem $0,5 \%$ de seu orçamento para cultura e atividades sociais. A Zona Franca de Manaus foi prorrogada por dez anos. Se determinou que a União deveria enviar projeto de isenção do setor da informática sessenta dias após a aprovação da emenda.

As únicas propostas inovadoras e com custos concentrados na reforma se referem à instituição do princípio do poluidor pagador e à possibilidade de lei federal regular o IPVA, instituindo alíquotas mínimas e diferenciadas de acordo com o uso do veículo.

Além disso, a reforma constitucionalizou três propostas que, apesar de terem custos concentrados, não alteravam o status quo: a prorrogação da DRU, a prorrogação da CPMF e a isenção da exportação de produtos primários e semielaborados. Assim, a rigor, o setor social, os contribuintes e os estados não perderam recursos, na verdade, eles tiveram consolidada uma situação que lhes era desfavorável. Como mostrou uma longa série de série de pesquisas comportamentais (Arnold, 1990, pp. 32-33), (Pierson, 1996, p. 146), os atores avaliam muito diferentemente perder e deixar de ganhar, sempre acreditando que ao segunda possibilidade é menos pior do que a primeira.

Por fim, cabe mencionar que a PEC 41/2003 prescreveu constitucionalmente que as contribuições sociais sobre faturamento (PIS/PASEP e COFINS) seria não cumulativas, se aproximando do princípio do IVA. Esta importante medida, que melhorou sensivelmente a estrutura dos tributos indiretos federais, também foi fruto de uma construção prévia incremental. O governo Fernando Henrique já havia transformado o PIS/PASEP em tributo sobre valor agregado através da lei 10.637/02. Tal medida teve um caráter teste, fazendo com que as burocracias tributárias examinassem os efeitos do novo sistema do imposto. O governo Lula continuou a política e transformou a COFINS (que tem arrecadação muito maior do que o PIS) em cumulativa com a lei 10.8333/03, que tramitou paralelamente à PEC 41/2003. Assim, quando foi aprovada a emenda 42, as contribuições já não eram cumulativas, portanto, ela apenas consolidou uma situação que já existia. 


\begin{tabular}{|c|c|c|}
\hline \multicolumn{3}{|c|}{ Análise EC 42-2003 } \\
\hline Proposta & Ganhadores & Perdedores \\
\hline $\begin{array}{l}\text { Ampliação dos Direitos dos Contribuintes } \\
\text { (noventena; atribuição de o Senado avaliar o } \\
\text { sistema tributário) }\end{array}$ & Contribuintes & Difuso \\
\hline $\begin{array}{l}\text { Prerrogativas Especiais às Burocracias Tributárias } \\
\text { (recursos vinculados e prioritários; carreira } \\
\text { específica; ação integrada por convênio) }\end{array}$ & Burocracias tributárias & Difuso \\
\hline $\begin{array}{l}\text { Competitividade e Política Industrial } \\
\text { (permissão para alíquotas diferenciadas em } \\
\text { função de política industrial ou comercial; } \\
\text { cobrança de ICMS e contribuições nas } \\
\text { importações) }\end{array}$ & Empresas nacionais & Difuso \\
\hline $\begin{array}{l}\text { Isenção de impostos nos produtos primários e } \\
\text { serviços exportados - Lei Kandir }\end{array}$ & $\begin{array}{l}\text { Exportadores de } \\
\text { produtos primários e } \\
\text { de serviços }\end{array}$ & $\begin{array}{l}\text { Estados exportadores } \\
\text { de produtos } \\
\text { primários }\end{array}$ \\
\hline $\begin{array}{l}\text { Contribuições não cumulativas } \\
\text { (as contribuições sociais sobre faturamento ou } \\
\text { receita - PIS/PASEP e COFINS - serão não } \\
\text { cumulativas) }\end{array}$ & Difuso & Difuso \\
\hline $\begin{array}{l}\text { Descentralização do ITR } \\
\text { (o ITR pode ser repassado aos Municípios, } \\
\text { hipótese na qual eles passarão a ter direito a 100\% } \\
\text { do imposto) }\end{array}$ & Municípios & Difuso \\
\hline Prorrogação da DRU até o fim de 2007 & União & Setor social \\
\hline $\begin{array}{l}\text { Prorrogação da CPMF até o fim de } 2007 \\
\text { (também retira a vinculação da CPMF ao fundo de } \\
\text { combate à pobreza) }\end{array}$ & União & $\begin{array}{l}\text { Contribuintes, setor } \\
\text { social }\end{array}$ \\
\hline $\begin{array}{l}\text { Institui o princípio do Poluidor Pagador } \\
\text { (a tributação poderá discriminar os impostos de } \\
\text { acordo com seu impacto no meio ambiente) }\end{array}$ & $\begin{array}{l}\text { União, estados, } \\
\text { ambientalistas }\end{array}$ & Empresas poluidoras \\
\hline $\begin{array}{l}\text { Pequenas Empresas } \\
\text { (institui tratamento privilegiado às pequenas } \\
\text { empresas, com cobrança unificada de impostos } \\
\text { federais, estaduais e municipais). }\end{array}$ & Pequenas empresas & Difuso \\
\hline $\begin{array}{l}\text { Partilha da CIDE-combustíveis } \\
\text { (aumenta de dez para } 25 \% \text { a parcela da CIDE } \\
\text { combustíveis que é transferida aos estados) }\end{array}$ & Estados & União \\
\hline $\begin{array}{l}\text { Majoração de impostos e taxas estaduais } \\
\text { (IPVA com mínimos nacionais e diferenciados de } \\
\text { acordo com a utilização) }\end{array}$ & Estados & $\begin{array}{l}\text { Proprietários de } \\
\text { automóveis }\end{array}$ \\
\hline $\begin{array}{l}\text { Redução de Impostos } \\
\text { (isenção de ICMS rádios e TVs de transmissão } \\
\text { gratuita; lei da informática) }\end{array}$ & $\begin{array}{l}\text { Rádios e TVs de } \\
\text { transmissão gratuita, } \\
\text { informática }\end{array}$ & Difuso \\
\hline $\begin{array}{l}\text { Vinculações Orçamentárias } \\
\text { (os estados podem vincular recursos para cultura } \\
\text { e assistência social) }\end{array}$ & $\begin{array}{l}\text { Setores social e de } \\
\text { cultura }\end{array}$ & Difuso \\
\hline $\begin{array}{l}\text { Prorrogação da Zona Franca de Manaus por dez } \\
\text { anos }\end{array}$ & Amazonas & Difuso \\
\hline
\end{tabular}




\section{Conclusão}

Vemos que o motivo para o fracasso das três propostas de reforma tributária analisada não pode ser a ingovernabilidade do sistema, pois o Executivo é normalmente bem sucedido nas votações do Congresso. Também não é o poder de veto das bancadas estaduais, pois elas costumam agir mais partidariamente do que regionalmente. Os motivos para a derrota do governo estão em suas próprias estratégias.

Como vimos, as três propostas analisadas compartilham os principais pontos. Todas procuram unificar a legislação do ICMS, proibir a guerra fiscal, instituir o princípio do destino, reformar as vinculações constitucionais, aumentar a progressividade e a eficiência do sistema. Mas, acima de tudo, buscam fazer grandes alterações estruturais no sistema tributário. A grande quantidade de propostas leva ao surgimento de muitas clivagens. Como é muito difícil para os negociadores operarem em tantas dimensões diferentes, surgem incertezas quanto ao resultado final da reforma, aumentando a aversão ao risco dos atores.

Tomemos como exemplo o papel de um parlamentar interessado em defender os interesses do estado de São Paulo. Ele é a favor de manter a tributação do ICMS na origem; logo, é contra as propostas do governo. Contudo, ele defende o fim da guerra fiscal, por isso, é a favor da reforma. No entanto, ele é contra desonerar os bens de capital, logo, é contra a proposta do governo. Mas, também, ele quer desonerar os alimentos, o que o coloca a favor da proposta. Como o resultado final da proposta depende de complexas negociações com parlamentares de todos os estados e todos partidos, ele pode facilmente concluir que é melhor deixar as coisas como estão a arriscar ver seu estado em sérias dificuldades financeiras.

Não se trata, aqui, de retornar ao argumento do veto federativo de Fernando Abrucio (1998). O governo federal consegue, em geral, contornar os interesses dos estados. Mas isso acontece em reformas mais simples, onde há menos atores na mesa de negociação, menos dimensões em disputa e, portanto, melhores condições de firmar garantias e compensações. Não se pode negar que a dimensão federativa é fundamental na discussão da reforma. Apenas se está afirmando que ela não é o único problema, pois se fosse, a reforma estaria aprovada. $\mathrm{O}$ argumento da multidimensionalidade não exclui problemas federativos, apenas diz que há problemas adicionais. 
Por exemplo, imaginemos um parlamentar que tem por bandeira a defesa dos interesses empresariais. Ele é a favor da unificação do ICMS, pois isso simplifica o trabalho tributário das empresas. Portanto, ele é a favor da reforma tributária. Contudo, ele é extremamente avesso a propostas que aumentem a carga tributária. Então ele não apóia a proposta, pois não há mecanismos críveis da parte do governo para garantir que a PEC melhora a qualidade dos tributos sem aumentar sua quantidade. No entanto, ele deseja muito a desoneração dos bens de capital e das exportações. E assim, ele começa a pensar seriamente em apoiar a reforma do governo. Porém, a proposta aumenta a progressividade dos impostos sobre a propriedade, o que o afeta profundamente. Mais uma vez, não se pode saber de antemão qual ponto vai prosperar nem qual malogrará durante o processo de tramitação da reforma. O parlamentar acima poderá justamente temer que os pontos que ele apoia fracassem e os pontos que ele rejeita sejam vitoriosos. No final, pode ser prudente não apoiar a reforma e se contentar com o status quo.

Com isso, sintetizamos o argumento da multidimensionalidade: cada parlamentar possui uma "cesta" de preferências sobre as diferentes dimensões da proposta. Mesmo que muitos pontos de sua "cesta" sejam largas maiorias no Congresso, não há uma "cesta" capaz de formar o número mágico de $3 / 5$ dos parlamentares da Câmara e do Senado. Este é o motivo porque reformas amplas são mais difíceis de aprovar do que reformas concisas.

A reforma tributária demonstrou isso várias vezes. A progressividade do IPTU não foi aprovada enquanto esteve no guarda-chuva da PEC 175/1995; mas foi aprovada na Emenda 29, uma proposta bem mais enxuta. A desoneração das exportações estava na proposta inicial da PEC 175/1995, mas foi aprovada por estar na Lei Kandir. Com isso, ficou bem mais fácil para a Emenda 42/2003 constitucionalizar esse mecanismo ele não alterava mais o status quo. A taxa municipal de iluminação e a regulamentação do ISS são outros exemplos. Estiveram na PEC 175, mas somente foram aprovadas nas emendas 39 e 33 .

Mesmo as grandes reformas constitucionais pós-1988 não tentavam operar em tantas dimensões ao mesmo tempo. Tanto na reforma do judiciário, quanto na reforma administrativa, havia apenas um setor com perdas claras. No caso da reforma do judiciário eram os tribunais inferiores. No caso da reforma administrativa, os servidores. 
Isso facilitava as negociações, pois havia menos cadeiras nas mesas de negociação e menos itens na pauta.

Não se está desprezando a complexidade das reformas do judiciário e administrativa. Uma demorou doze anos para ser aprovada e outra, três anos. Mas a pouca variedade dos perdedores permitiu dar compensações. Quando não havia mais como negociar, foi-se a plenário ver quem tinha mais votos. A perda concentrada em apenas um setor dificulta a formação de coalizões de veto. No Brasil, o presidente e os líderes partidários formam um verdadeiro cartel legislativo, controlando rigidamente a agenda do Congresso. As minorias não têm grande poder para barrar os projetos da maioria (Figueiredo e Limongi, 1999; Limongi, 2006), a menos que se juntem para formar uma maioria. As reformas tributárias multidimensionais favoreceram $\mathrm{o}$ surgimento desta maioria de veto.

A maioria dos itens das reformas tributárias poderia ser bem sucedida se tramitassem em reformas menores. Afinal, a experiência internacional mostra que os sistemas tributários são altamente path dependent (Bird, 1992; Tanzi e Zee, 2000; Mahon, 2004; (Melo, 2005). Inversamente, é raro que propostas estruturais sejam aprovadas. Mais comum são as reformas incrementais ${ }^{78}$. É possível que a redução das dimensões políticas das propostas elencadas acima tivesse viabilizado sua aprovação. No modelo exposto abaixo:

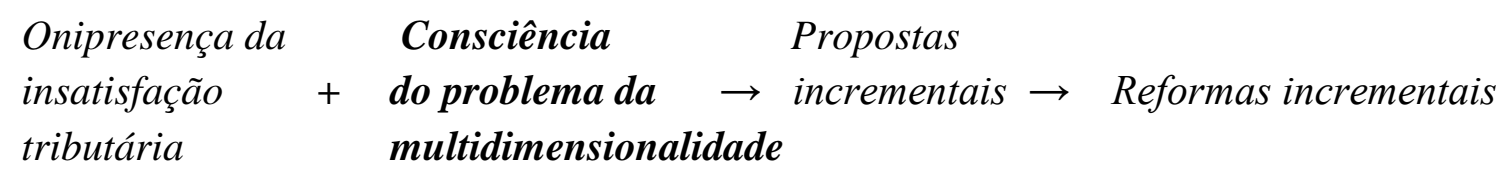

Obviamente, não se está querendo dizer que basta uma reforma ser unidimensional ou ter poucas clivagens para ser bem sucedida. Para uma reforma ser aprovada é preciso bem mais do que isso. Mas a multidimensionalidade pode converter maiorias em minorias.

\footnotetext{
${ }^{78}$ Varsano (1996) argumenta que mesmo a grande reforma de 1965-67 foi mais um passo de uma lenta evolução Em suma, a reforma da década de 60, a despeito de ter sido extremamente profunda e modernizante, foi apenas um passo a mais -- largo, é verdade -- na evolução do sistema tributário. A lógica do processo de evolução, que não admite descontinuidades, foi respeitada. Dessa lógica, fundamentada em justificada aversão a riscos, resulta que todo sistema tributário, mesmo os instituídos por reformas profundas, herda características de seu antecessor e reflete não só as ideias e condições reinantes na sociedade à época de sua instituição como as que prevaleceram no passado. (pg. 21)
} 
Podemos dar uma formulação popperiana ao argumento (Popper, 2007). Se afirmarmos que a multidimensionalidade é a causa do fracasso das reformas, também afirmamos, por dedução lógica, que não é possível reunir multidimensionalidade e vitória, pois seria o mesmo que afirmar o antecedente e negar o consequente.

"A multidimensionalidade causa a = "Não é possível haver reforma falha da reforma tributária" tributária multidimensional vitoriosa"

Com isso se cria uma forma factível de se refutar a tese exposta acima. Caso um governo consiga aprovar uma reforma estrutural ampla, então, a hipótese deste trabalho não pode ser aceita. Este é o nosso contrafactual. 


\section{Bibliografia}

Abrucio, F. L. (1998). Os Barões da Federação : os governadores e a redemocratização brasileira . São Paulo: HUCITEC: Depto. de Ciência Política da USP.

Ames, B. (2003). Os Entraves da Democracia no Brasil. Rio de Janeiro: FGV.

Arbix, G. (2002). Políticas do Desperdício e Assimetria entre Público e Privado na Indústria Automobilística. Revista Brasileira de Ciências Sociais, São Paulo, v. 17, n. 48 , pp. 109-129.

Arnold, R. D. (1990). The logic of congressional action. New Haven: Yale University Press.

Arretche, M. (2007). The Veto Power of Subnational Governments in Brazil. Brazilian political science review , 40-73.

Arrow, K. (1951). Social Choice and Individual Values. New York: Wiley.

Banco Mundial. (2009). Coporate tax regulation by Contry. Acesso em 04 de 01 de 2010, disponível em Doing Bussiness:

http://www.doingbusiness.org/documents/FullReport/2010/Paying-Taxes-2010.pdf

Baratto, G. (2006). O regime tributário do ICM e ICMA nas transações interestaduais e a competição fiscal entre os estados. In: S. Prado, \& F. Rezende, Forúm Fiscal dos Estados. Relatório 2 - Competição Fiscal (pp. 111-171). Disponível em http://forumfiscal.fgv.br/default.aspx.

Bertolucci, A. V., \& Nascimento, D. T. (2002). Quanto custa pagar Tributos? Revista de Contabilidade e Finanças, FEA USP, n. 29.

Biderman, C., \& Arvate, P. (2005). Economia do Setor Público no Brasil. Rio de Janeiro: Elsevier.

Biderman, C., Lima, F., Tysler, M., \& Avarte, P. (2004). Um estudo considerando a "guerra fiscal" como elemento de interação na renda tributária dos estados brasileiros entre 1988/1998. Série para Discussão Cepesp, GV Pesquisa (NPP), Número 03.

Bird, R. (1992). Tax reform in Latin America: a review of some recent experience. Latin American Research Review, 27 , pp. 7-36.

Black, D. (1958). Theory of Committees and Elections. Cambridge: Cambridge University Press.

Borba, A. C. (2007). Considerações sobre os efeitos da remuneração através do subsídio. Acesso em 04 de 11 de 2010, disponível em Jus Navigati:

http://jus2.uol.com.br/doutrina/texto.asp?id=9703

Brennan, G. e. (1980). The power of tax: analytical foundations of a fiscal constitution. Cambridge: Cambridge University Press. 
Buchanan, J. M. (25(2) de 1995). Federalism As an Ideal Political Order and an Objective for Constitutional Reform. Publius: The Journal of Federalism , pp. 19-27.

Carey, J. M., \& Reinhardt, G. Y. (2003). Impacto das Instituições Estaduais na Unidade das Coalizões Parlamentares no Brasil. Dados, vol 46, n 4 , 773-804.

CDES. (2009). Indicadores de Equidade do Sistema Tributário Nacional. Acesso em 01 de 04 de 2010, disponível em CDES:

http://www.cdes.gov.br/exec/documento/baixa_documento.php?p=f01200e46c415bda5dc3f 33ee142ed652ad50cbebbf308b6f5cca2f0234d65df05c1d61cea079f9e30ccb4a1f93fd65cc105

Cheibub, J. A., Figueiredo, A., \& Limongi, F. (2009). Partidos Políticos e Governadores como Determinantes do Comportamento Legislativo na Câmara dos Deputados, 1988-2006. Dados , 263-299.

Coase, R. H. (1937). The Nature of the Firm. Economica 4 (16) , 386-405.

Comin, Á., \& Freire, C. T. (2009). Sobre a qualidade do crescimento: atores, instituições e desenvolvimento local. Novos estudos - CEBRAP, São Paulo, $n .84$, pp. Disponível em $<$ http://www.scielo.br/scielo.php?script=sci_arttext\&pid=S0101-3300.

Cossío, F. A. (2000). Disparidades econômicas inter-regionais, capacidade de recursos tributários, esforço fiscal e gasto público no federalismo brasileiro. 1998: Rio de Janeiro : PUC/RJ.

Dahl, R. A. (1967). Who governs? Democracy and power in an American city. New Haven: Yale University Press.

Downs, A. (1999). Uma teoria econômica da democracia. São Paulo: EDUSP.

Dulci, O. S. (2002). Guerra Fiscal, Desenvolvimento Desigual e Relações Federativas no Brasil. REVISTA DE SOCIOLOGIA E POLÍTICA № 18: , pp. 95-107.

Elster, J. (1994). Peças e engrenagens das ciências sociais. Rio de Janeiro : Relume Dumara.

Entidades Sociais. (14 de 04 de 2009). Manifesto em Defesa dos Direitos Sociais Básicos sob Ameaça na Reforma Tributária. Acesso em 22 de 11 de 2010, disponível em Conselho Nacional de Saúde: http://conselho.saude.gov.br/webtributaria/doc/carta.pdf

Fenafisco. (2008). Apresenta2NT.ppt. Acesso em 22 de 11 de 2010, disponível em Federação Nacional do Fisco - FENAFISCO: www.fenafisco.org.br/arquivos/Apresenta2NT.ppt

Ferejohn, J. A. (1986). Logrolling in an Institutional Context: A Case Study of Food Stamp Legislation. In: L. C. Dodd, L. N. Rieselbach, \& G. C. Wright Jr, Congress and Policy Change. New York: Agathon.

FIEB. (2000). Seminário Reforma Tributária -Anais. Salvador: Federação das Indústrias do Estado da Bahia.

Figueiredo, A., \& Limongi, F. (1999). Executivo e Legislativo na Nova Ordem Constitucional. Rio de Janeiro: Fundação Getúlio Vargas. 
Figueiredo, A., \& Limongi, F. (2004). Modelos de Legislativo: o Legislativo Brasileiro em Perspectiva Comparada. Revista Plenarium - Câmara dos Deputados, v1 , pp. 41-56.

Forum Fiscal dos Estados. (2006). Harmonização Tributária. Disponível em http://www.esaf.fazenda.gov.br/esafsite/cursos_presenciais/Forum_Estados/FFEB_Caderno_n _3.pdf: Cadernos Forúm Fsical No. 3.

Gilligan, T. W., \& Krehbiel, K. (1994). The Gains from Exchange Hypothesis of Legislative Organization. Legislative Studies Quarterly ; Vol. 19, No. 2 , 181-214.

Gordon, R. H. (1983). An Optimal Taxation Approach to Fiscal Federalism. . Quarterly Journal of Economics. Vol.98.

Hoffman, S. e. (2006). O Sacrifício Equitativo na Tributação Brasileira. Brasília, IPEA, Textos para a Discusão .

IBGE. (2003). Contas Nacionais 2002. Brasília : IBGE. Disponível em http://www.ibge.gov.br/home/estatistica/economia/despesaspublicas/financaspublicas_2003 /tab127.pdf.

Immergut, E. M. (1996). As Regras do Jogo: a lógica da política de saúde na França, na Suíça e na Suécia. Revista Brasileira de Ciências Sociais, $n 30$.

Immergut, E. (2006). O Núcleo Teórico do Novo Institucionalismo. In: E. Saraiva, \& E. Ferrarezi, Políticas Públicas - Coletânia. Volume 1 (pp. 155-196). Brasília: Enap.

Krehbiel, K. (1988). Spatial Models of Legislative Choice. Legislative Studies Quarterly, Vol. 13, No. 3 , 259-319.

Lamounier, B. (1996). A Democracia Brasileira no Simiar do Século 21. São Paulo: Fundação Konrad Adenauer.

Lijphart, A. (2003). Modelos de Democracia : desempenho e padrões de governo em 36 países. Rio de Janeiro: Civilização Brasileira.

Lowi, T. J. (1964). American Business, Public Policy. Case-Studies, and Politica Theory. World Politics, vol 16, No. 4 , 667 -.

Mahon, J. (2000). "Was Latin America too rich to prosper". In: M. Jeffrey Frieden, \& P. J. Tomz, Modern political economy and Latin America: theory and policy. Boulder, CO: Westview Press.

Mainwaring, S. (2001). Sistemas Partidários em Novas Democracias : o caso do Brasil . Porto Alegre: Mercado Aberto.

Mancuso, W. P. (2007). O lobby da indústria no Congresso Nacional: empresariado e política no Brasil contemporâneo. São Paulo: Humanitas : EDUSP.

MARE. (1995). Plano Diretor da Reforma do Aparelho do Estado. Brasília-DF: Ministério da Administração Federal e Reforma do Estado - Brasil.

Marshal, W. J., \& Weingast, B. R. (1988). The Industrial Organization of Congress; or, Why Legislatures, Like Firms, Are Not Organizedas Markets. The Journal of Political Economy, Vol. 96, No. 1 , 132-163. 
Matus, C. (2007). O Método PES. São Paulo: Edições Fundap.

McKelvey, R. D. (1979). General Conditions for Global Intransitivities in Formal Voting Models. Econometrica Vol. 47, No. 5 , 1085-1112.

McKelvey, R. D. (1976). Intransitivities in Multidimensional Voting Models and Some Implications for Agenda Control. Journal of Economic Theory 12 , 472-482.

Melo, M. (2002). As Reformas constitucionais no Brasil: instituições políticas e processo decisório. Rio de Janeiro-RJ, Brasília-DF: Revan, Ministério da Cultura.

Melo, M. A. (2005). O leviatã brasileiro e a esfinge argentina: os determinantes institucionais da política tributária. Revista Brasileira de Ciências Sociais [online]; vol.20, n.58 , pp. 91-128.

Melo, M. A., \& Azevedo, S. (1997). A Política da Reforma Tributária: Federalismo e Mudança Constitucional. . Revista Brasileira de Ciência Sociais, vol.12, n.35 , http://www.scielo.br/scielo.php?script=sci_arttext\&pid=S0102-69091997000300006.

Ministério da Fazenda. (1999). Análise do Substitutivo do Relator da Reforma Tributária. Acesso em 20 de 11 de 2010, disponível em Ministério da Fazenda: http://www.fazenda.gov.br/portugues/releases/1999/r991123.asp

Nascimento, S. P. (2008). Guerra fiscal: uma avaliação comparativa entre alguns estados participantes. Economia Aplicada. vol.12 no.4 Ribeirão Preto .

North, D. C. (2001). Instituiciones, cambio institucional y desempeño económico. México: Fondo de Cultura Económica.

Oliveira, L. G. (1999). Federalismo e Guerra Fiscal. Pesquisa e Debate, volume 10 .

Ordeshook, P. C. (1993). The Spatial Analysis of Elections and Committees: four decades of research. Social Science Working Paper 870: California Institute of Technology , 1-32.

Pedrosa, I., \& Cornils, F. (2000). A Reforma Tributária e a Visão de Empresários da RMR. Revista de Ciências da Administração, vol. 1, no 1 .

Pierson, P. (1996). The New Politics of the Welfare State. World Politics 48 (2) , pp. 143-179.

Pierson, P. (2000). Increasing Returns, Path Dependence, and the Study of Politics. American Political Science Review; 94 (2) , pp. 251-267.

Plott, C. R. (1967). A notion of equilibrium and its possibility under majority rule. American Economic Review 57 , 787-806.

Popper, K. R. (2007). A Lógica da Pesquisa Científica. São Paulo: Cultrix.

Prado, S. (2006). Sínteses dos Debates. In: S. Prado, \& F. Rezende, Fórum Fiscal dos Estados, Relatório de Competição Fiscal (Número 2) (pp. 6-13). http://forumfiscal.fgv.br/default.aspx.

Prado, S., \& Cavalcanti, E. G. (2000). A guerra fiscal no Brasil. São Paulo; Brasília: FUNDAP; FAPESP; IPEA. 
Rangel, P. E., \& Medeiros Netto, J. d. (2003). Histórico De Reformas Reforma Tributária: breve notícia sobre oito anos de trabalhos no âmbito da câmara dos deputados. Brasília: Câmara dos Deputados.

Riker, W. H. (1980). Implications from the disequilibrium of majority rule for the study of institutions. American Political Science Review 74 , 432-447.

Sadek, M. T. (2010). Poder Judiciário: uma nova instituição. Cadernos Adenauer , pp. 27-45.

Sapienza, V., Torres, D., \& Carvalho, J. E. (1998). Guerra fiscal: com ela todos perdem. 2. ed.: São Paulo.

Shepsle, K. A. (feb de 1979). Institutional Arrangements and Equilibrium in Multidimensional Voting Models. American Journal of Political Science, Vol. 23 , 27-59.

Shepsle, K. A., \& Weingast, B. R. (1981). Structure-induced equilibrium and legislative choice. Public Choice 37 , 503-519.

Shepsle, K. A., \& Weingast, B. R. (1994). Positive Theories of Congressional Institutions. Legislative Studies Quarterly; Vol. 19, No. 2 , 149-179.

Shepsle, K. (1986). The positive theory of legislative institutions: an enrichment of social choice and spatial models. Public Choice $50,135-178$.

Silva, N. C. (2001). Resenha Sobre a Competição Tributária entre as Regiões. Textos para a Discussão, IPEA, $n 813$.

Stepan, A. (1999). Para uma Nova Análise Comparativa do Federalismo e da Democracia: Federações que Restringem ou Ampliam o Poder do Demos. Dados , p. v 42 n.2.

Stigler, G. (1984). The Theory of Economic Regulation. In: T. Ferguson, \& J. Rogers, The Political economy: readings in the politics and economics of American Public Policy (pp. 67-81). New York: Armonk.

Tanzi, V., \& Zee, H. H. (2000). "Tax policy for emerging markets: developing countries". IMF Working papers 00/35, Washington.

Tiebout, C. M. (1956). A Pure Theory of Local Expenditures. Journal of Political Economy; N 64; October, pp. 416-424.

Tsebelis, G. (1995). Processo decisório em sistemas políticos : veto players no presidencialismo, parlamentarismo, multicameralismo e pluripartidarismo. Revista Brasileira de Ciências Sociais, São Paulo, v. 12, n. 34 , 89-117.

Tyler, W. (1998). Promoting economic growth in Ceará. Background paper for the World Bank's Ceará State Economic Memorandum .

Udovic, L. (31 de 03 de 2009). Os Direitos Sociais na Reforma Tributária. Acesso em 22 de 11 de 2010, disponível em Instituto de Estudos Socioeconomicos - INESC:

http://www.chamadacontrapobreza.org.br/biblioteca/textos/audiencia-publica-da-comissaode-seguridade-reforma-

tributaria/Audiencia\%20publica\%20da\%20Comissao\%20de\%20Seguridade.pdf 
Varsano, R. (1981). O sistema tributário de 1967: adequado ao Brasil de 80? Pesquisa em Planejamento Economico, 11(1) .

Varsano, R. (1995). A Tributação do Comércio Interestadual: ICMS atual versus ICMS partilhado. Texto para Discussão. No. 382 IPEA.

Varsano, R. (1996). A Guerra Fiscal do ICMS: quem ganha e quem perde. Planejamento e Políticas Públicas.

Varsano, R. (1997). A evolução do sistema tributário brasileiro ao longo do século: anotações e reflexões para futuras reformas. Pesquisa e Planejamento Econômico, v. 27, n. 1 , pp. p. 1-40.

Varsano, R. (1999). Subnational Taxation and the Treatment of Interstate Trade in Brazil: Problems and a Proposed Solution. Decentralization and Accountability of the Public Sector. Valdivia, Chile: Presented to the World Bank's Annual Bank Conference on Development in Latin America and the Caribbean (ABCD-LAC).

Varsano, R., Pessoa, E., Silva, N., Roberto, A. J., Araujo, E., \& César, R. J. (1998). Uma Análise da Carga Tributária do Brasil. Textos Para a Discussão, 0583.

Vianna, S. e. (2000). Carga Tributária Direta e Indireta sobre as Unidades Familiares no Brasil: Avaliação de sua Incidência nas Grandes Regiões Urbanas em 1996. Brasília: IPEA, set. 2000 (Texto para discussão, 757).

Viol, A. L. (2000). O processo de Reforma Tributária no Brasil: mitos e verdades. Brasília: Editora da UnB. Disponível em

http://www.tesouro.fazenda.gov.br/Premio_TN/vpremio/financas/2tefpVPTN/VIOL_Andrea.p df.

Wilson, Q. J. (1984). Politics of Regulation. In: T. Ferguson, \& J. Rogers, The Political economy: readings in the politics and economics of American Public Policy (pp. 82-103). New York: Armonk.

Zockum, M. H. (2007). Simplificando o Brasil: Propostas de Reforma na Relação Econômica do Governo com o Setor Privado. São Paulo: FIPE (Texto para Discussão n. 03) . 


\section{Anexo I: impostos cumulativos VS. Impostos sobre valor agregado.}

\section{a- Impostos Cumulativos}

Um imposto pode ser definido como "em cascata", ou "cumulativo", quando a unidade econômica correspondente a cada etapa da produção paga uma porcentagem fixa de imposto sobre o valor do produto. Por exemplo: suponha um produto que tenha quatro etapas de produção. Podemos pensar o óleo de cozinha (produção da soja => óleo bruto $=>$ óleo refinado no atacado $\Rightarrow>$ óleo refinado no varejo). Apenas para seguir o exemplo, vamos supor que os preços das mercadorias sem impostos sejam respectivamente 50 (soja grão), 110, 143 e 200 (óleo refinado no supermercado). Se cada etapa de produção por tributada em $10 \%$ a alíquota real para o consumidor final será de $27,85 \%$, conforme mostra a tabela a seguir:

\begin{tabular}{|c|c|c|c|c|}
\hline \multicolumn{5}{|l|}{ Imposto em Cascata } \\
\hline Etapa de produção & $\begin{array}{c}\text { Preço da } \\
\text { mercadoria s/ } \\
\text { impostos (a) }\end{array}$ & $\begin{array}{c}\text { Alíquota } \\
\text { cumulativa de } \\
10 \%(b)\end{array}$ & $\begin{array}{c}\text { Preço da } \\
\text { mercadoria c/ } \\
\text { imposto (c) }\end{array}$ & $\begin{array}{c}\text { Fórmula } \\
\left(\mathrm{a}+\left(\mathrm{c}_{\mathrm{t}-1}-\mathrm{a}_{\mathrm{t}-1}\right) *(1+b)\right.\end{array}$ \\
\hline Soja grão & 50 & $10 \%$ & 55 & $=50+10 \%$ \\
\hline Óleo Bruto & 110 & $10 \%$ & 126,5 & $=\left(110+5^{*}\right)+10 \%$ \\
\hline Óleo Refinado (atacado) & 143 & $10 \%$ & 175,45 & $=\left(143+16,5^{*}\right)+10 \%$ \\
\hline Óleo Refinado (varejo) & 200 & $10 \%$ & 255,695 & $=\left(200+32,45^{*}\right)+10 \%$ \\
\hline Alíquota final: & & $27,85 \%$ & & $=255,695 / 200^{* *}$ \\
\hline \multicolumn{5}{|c|}{ *- Este algarismo se refere ao imposto pago na etapa anterior de produção } \\
\hline ** - Menos um & & & & \\
\hline
\end{tabular}

A razão para esse aumento do imposto é que o tributo pago na etapa anterior (o número seguido de asterisco na formula) entra na base de cálculo na etapa seguinte. Os impostos cobrados dessa maneira acabam punindo as cadeias de produção mais longas, pois a alíquota final cresce de forma geométrica conforme cresce o número de etapas de produção. A indústria é particularmente punida por esse sistema, pois a agricultura e os serviços não costuma possuir muitas etapas. Dentro da indústria, os bens duráveis e os eletroeletrônicos são os mais afetados, pois são produtos complexos, que requerem a colaboração de um grande número de empresas fornecedoras. Assim, impostos cumulativos tendem a desfavorecer o surgimento de indústrias de bens sofisticados, 
mantendo o setor produtivo do país preso aos setores primários ou às indústrias tradicionais.

Para se proteger desse tipo de tributo, as empresas costumam se verticalizar, pois quando elas internalizam as etapas de produção, elas conseguem diminuir sua tributação efetiva. Tal precaução vai, entretanto, na contramão das tendências gerenciais recentes das empresas de se concentrarem na atividade em que possuem vantagem comparativa e terceirizar os demais setores. Quando há muitos tributos cumulativos, as empresas não conseguem ter o perfil gerencial moderno, que pressupõe empresas enxutas e flexíveis. Em outras palavras, esse tipo de tributo induz uma verticalização excessiva das empresas, pois se elas tivessem que decidir seu organograma apenas por fatores gerenciais, elas seriam menores.

\section{b- Impostos sobre Valor Agregado}

Um imposto pode ser definido como "sobre valor agregado" quando o fabricante é tributado somente sobre a quantidade de valor agregada ao produto em cada etapa de produção. Existem várias técnicas de transformar tributos cumulativos em tributos sobre valor agregado. A mais comum no Brasil é dar o direto das empresas descontarem em seu próprio imposto o imposto cobrado na compra de seus insumos.

\begin{tabular}{|c|c|c|c|c|c|c|}
\hline Etapa de produção & $\begin{array}{l}\text { Preço da } \\
\text { mercadoria } \\
\text { s/ impostos } \\
\text { (a) }\end{array}$ & $\begin{array}{l}\text { Alíquota } \\
\underline{\text { não }} \\
\text { cumulativa } \\
\text { de } 10 \% \text { (b) }\end{array}$ & $\begin{array}{c}\text { Valor } \\
\text { Agregado } \\
\text { (c) }\left(a-a_{t-1}\right)\end{array}$ & $\begin{array}{c}\text { Preço c/ } \\
\text { imposto } \\
\text { (d) } \\
\text { (a*110\%) }\end{array}$ & $\begin{array}{c}\text { Créditos } \\
\text { (e) } \\
\left(d_{t-1}-a_{t-1}\right)\end{array}$ & $\begin{array}{c}\text { Imposto } \\
\text { pago pela } \\
\text { empresa } \\
\text { ([d-a]-e) }\end{array}$ \\
\hline Soja grão & 50 & $10 \%$ & 50 & 55 & 0 & 5 \\
\hline Óleo Bruto & 110 & $10 \%$ & 60 & 121 & 5 & 6 \\
\hline Óleo Refinado (atacado) & 143 & $10 \%$ & 33 & 157,3 & 11 & 3,3 \\
\hline Óleo Refinado (varejo) & 200 & $10 \%$ & 57 & 220 & 14,3 & 5,7 \\
\hline Alíquota final (d/a)*: & & $10,00 \%$ & & & & \\
\hline *-Menos um & & & & & & \\
\hline
\end{tabular}

Repare que nesse tipo de imposto a alíquota final é a mesma, não importa a quantidade de etapas de produção. Isso ocorre porque cada empresa paga apenas o imposto sobre o valor agregado por ela. Na tabela acima, pode-se reparar que o valor pago pela empresa é sempre igual ao valor agregado vezes a alíquota de $10 \%$ (c*b). Nesse sentido, o imposto é "neutro" no que se refere ao tamanho da cadeia produtiva. 
Por isso, ele não desincentiva a indústria sofisticada nem a horizontalização das empresas.

Por fim, é importante ressaltar que os impostos sobre valor agregado desestimulam a sonegação das empresas do meio da cadeia produtiva. Quando uma empresa compra insumos e não paga imposto, ela não consegue fornecer créditos para a etapa seguinte, fazendo com que a empresa compradora tenha que pagar o tributo integralmente em suas vendas. Assim, as empresas mais sujeitas à fiscalização (quase sempre as maiores empresas) recusam-se a comprar de fornecedores sonegadores ou informais. Por mais que seus preços sejam competitivos, eles têm o ônus de não geraram créditos fiscais. Assim, as empresas formais se tornam colaboradoras involuntárias do fisco. 


\section{Anexo II: princípio da origem atenuado}

O ICMS (e antes dele o ICM) adota o princípio da origem atenuado. Quando há transação comercial envolvendo mais de um estado, o estado de origem da mercadoria fica com uma parte do imposto e o estado de destino fica com outra parte. A proporção desta distribuição é determinada pela diferença entre a "alíquota interestadual" e a alíquota interna do produto. Desde 1990, a alíquota interestadual das regiões Sul e Sudeste (S/SE-ES) é de $7 \%$ e a das regiões Norte, Nordeste e Centro-Oeste, mais o estado do Espírito Santo (N/NE/CO+ES), é de 12\%. Tomemos o seguinte exemplo simplificado: se uma mercadoria com alíquota interna de 15\% sai de São Paulo para a Bahia. O estado de origem (no caso, São Paulo) fica com a alíquota interestadual de 7\%; os $8 \%$ restantes ficam com o estado de destino (Bahia). No caso contrário, uma mercadoria da Bahia indo para São Paulo, o estado de origem fica com $12 \%$ e os outros 3\% ficam com São Paulo. Assim, as regiões menos desenvolvidas ficam sempre em vantagem na transação interestadual. A Constituição de 1988 determinou que a energia elétrica, o petróleo e seus derivados são uma exceção a esta regra e são cobrados integralmente no destino.

Como dito acima, esse exemplo é simplificador e aproximado. A tabela a seguir mostra um exemplo hipotético que é mais próximo ao sistema real, ainda que também não mostre a grande complexidade do ICMS. Como a operacionalização do imposto funciona com um sistema de créditos, são eles que determinam a distribuição do tributo entre os estados. Os pressupostos da tabela I são:

- O imposto não integra a própria base de cálculo (incidência por fora). $\mathrm{Na}$ realidade isso não acontece, pois o ICMS incide "por dentro".

- Em todas as etapas de produção, a alíquota é de $20 \%$. A única distinção é a alíquota interestadual de $10 \%$ no caso 2. O ICMS real tem alíquotas diferenciadas por estado, por produto, por etapa e por destino da mercadoria. Como dito acima, para as regiões S/SE-ES a alíquota interestadual é de $7 \%$ e nas regiões N/NE/CO-ES ela é de 12\%. Também é preciso considerar que existem regimes diferenciados de tributação (como o SIMPLES) e isenções fiscais, benefícios e reduções da base de cálculo introduzem exceções ao sistema. 


\begin{tabular}{|c|c|c|c|c|}
\hline \multicolumn{5}{|l|}{ Pressupostos: } \\
\hline Etapa de produção: & Soja grão & Óleo Bruto & Óleo Refinado (atacado) & Óleo Refinado (varejo) \\
\hline $\begin{array}{l}\text { Preço da mercadoria s/ } \\
\text { impostos: }\end{array}$ & 50 & 110 & 143 & 200 \\
\hline Transação: & interna & interna & interestadual & $\mathrm{p} / \mathrm{o}$ consumidor final \\
\hline $\begin{array}{l}\text { Alíquota interestadual igual à } \\
\text { interna: }\end{array}$ & $20 \%$ & $20 \%$ & $20 \%$ & $20 \%$ \\
\hline $\begin{array}{l}\text { Alíquota interestadual menor } \\
\text { que a interna: }\end{array}$ & $20 \%$ & $20 \%$ & $\underline{10 \%}$ & $20 \%$ \\
\hline \multicolumn{5}{|c|}{ 1) No caso de alíquotas interes taduais iguais às internas (princípio da origem puro) } \\
\hline Preço da Compra c/ Imposto & - & 60 & 132 & 171,6 \\
\hline Créditos & 0 & 10 & 22 & 28,6 \\
\hline Débitos & $50 * 20 \%=10$ & $110 * 20 \%=22$ & $143 * 20 \%=28,6$ & $200 * 20 \%=40$ \\
\hline Saldo & $10-0=10$ & $22-10=12$ & $28,6-22=\mathbf{6 , 6}$ & $40-28,6=\mathbf{1 1 , 4}$ \\
\hline Preço da Venda c/ Imposto & $50+10=60$ & $110+22=132$ & $143+28,6=\mathbf{1 7 1 , 6}$ & $200+40=240$ \\
\hline Cabe ao estado de origem: & \multicolumn{2}{|c|}{$10+12+6,6=\mathbf{2 8 , 6}$} & & \\
\hline Cabe ao estado de destino: & \multicolumn{2}{|c|}{11,4} & & \\
\hline Total: & \multicolumn{2}{|r|}{40} & & \\
\hline \multicolumn{5}{|c|}{ 2) No caso de alíquotas interestaduais menores que internas (princípio da origem atenuado) } \\
\hline Preço da Compra c/ Imposto & - & 60 & 132 & 157,3 \\
\hline Créditos & 0 & 10 & 22 & 14,3 \\
\hline Débitos & $50 * 20 \%=10$ & $110 * 20 \%=22$ & $143 * 10 \%=14,3$ & $200 * 20 \%=40$ \\
\hline Saldo & $10-0=10$ & $22-10=12$ & $14,3-22=-7,7$ & $40-14,3=\mathbf{2 5 , 7}$ \\
\hline Preço da Venda c/ Imposto & $50+10=60$ & $110+22=132$ & $143+14,3=\mathbf{1 5 7 , 3}$ & $200+40=240$ \\
\hline Cabe ao estado de origem: & \multicolumn{2}{|c|}{$10+12-7,7=\mathbf{1 4 , 3}$} & & \\
\hline Cabe ao estado de destino: & \multicolumn{2}{|c|}{25,7} & & \\
\hline Total: & \multicolumn{2}{|r|}{40} & & \\
\hline \multicolumn{5}{|l|}{ Fórmulas: } \\
\hline Preço da Compra c/ Imposto (a) & $=$ & $\left(e_{t-1}\right)$ & & \\
\hline Créditos (b) & $=$ & $\left(c_{t-1}\right)$ & & \\
\hline Débitos (c) & $=$ & \multicolumn{3}{|c|}{ (preço do produto s/ imposto * alíquota do imposto) } \\
\hline Saldo (d) & $=$ & (c-b) & & \\
\hline Preço da Venda c/ Imposto (e) & $=$ & \multicolumn{3}{|c|}{ (preço do produto menos impostos $+\mathrm{c}$ ) } \\
\hline Cabe ao estado de origem: & $=$ & \multicolumn{2}{|c|}{ A soma dos três primeiros saldos } & \\
\hline Cabe ao estado de destino: & $=$ & \multicolumn{2}{|c|}{ A soma do último saldo } & \\
\hline Fonte: Baratta (2006), com algu & umas modifica & ções. & & \\
\hline
\end{tabular}

- No estágio 1 pressupõe-se que não há créditos. Isso é pouco factível, pois os agricultores conseguem créditos na compra de máquinas e insumos agrícolas. 
- As duas primeiras transações ocorrem entre contribuintes do mesmo estado. A terceira ocorre entre contribuintes de estados diferentes. A última transação ocorre entre um contribuinte (um varejista) e um não contribuinte (o consumidor final). Nesse último caso, não ocorre geração de créditos. No sistema real pode ocorrer que um agente do meio da cadeia de produção não seja contribuinte (ele pode estar enquadrado em um regime especial de tributação, como o SIMPLES), nesse caso a transação não gerará créditos e o ICMS se tornará um imposto cumulativo.

- No caso 2, a saída do estágio três para o estágio quatro faz com que o estado de origem tenha que pagar mais créditos do que o valor do seu débito. Nesses casos, a empresa poderá aproveitar esses créditos em outras operações (como vendas internas, por exemplo). Alguns estados permitem a comercialização de créditos de ICMS. Em alguns casos, o estado de origem pode devolver os créditos diretamente em dinheiro. Quando nenhum desses dois instrumentos existe, as empresas que têm a maiorias das compras internas e a maioria das vendas externas podem ter que arcar com estes custos, tornando o ICMS um imposto cumulativo. Notadamente, este é o caso das empresas do Pará atual.

-Na etapa 3, a transação interestadual, o estado de destino suporta menos crédito. Consequentemente, ele recebe uma quantidade maior de impostos, que é o objetivo do sistema. 